\title{
Guy Laforest
}

with the collaboration of Oscar Mejia Mesa

\section{Interpreting Quebec's Exile Within the Federation}

\section{Selected Political Essays}
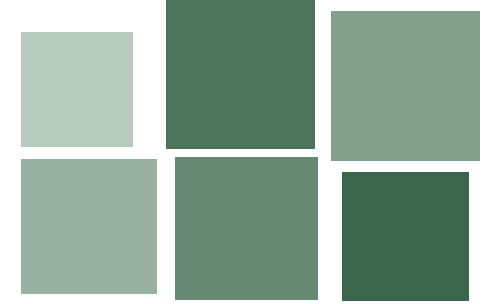

iVERSITAS 
This book combines the approaches of political theory and of intellectual history to provide a lucid account of Québec's contemporary situation within the Canadian federation.

Guy Laforest considers that the province of Québec, and its inhabitants, are exiled within Canada. They are not fully integrated, politically and constitutionally, nor are they leaving the federation, for now and for the foreseeable future. They are in between these two predicaments. Laforest provides insights into the current workings of the Canadian federation, and some of its key figures of the past fifty years, such as Pierre Elliott Trudeau, René Lévesque, Stephen Harper and Claude Ryan.

The book also offers thought-provoking studies of thinkers and intellectuals such as James Tully, Michel Seymour and André Burelle. Laforest revisits some key historical documents and events, such as the Durham Report and the 1867 and 1982 constitutional documents. He offers political and constitutional proposals that could contribute to help Québec moving beyond the current predicament of internal exile.
Guy Laforest is Full Professor in the department of political science, Université Laval, Québec, Canada. His main areas of teaching and research are political theory, intellectual history in Canada and Québec, theories of federalism and of nationalism. He is vice-president of the International Association for Québec Studies and a Fellow of the Royal Society of Canada. 




\section{Interpreting Quebec's Exile Within the Federation}

\section{Selected Political Essays}

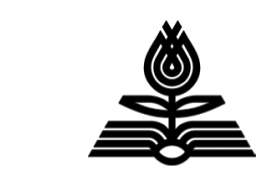

\section{P.I.E. Peter Lang}

Bruxelles $\cdot$ Bern $\cdot$ Berlin $\cdot$ Frankfurt am Main $\cdot$ New York $\cdot$ Oxford $\cdot$ Wien 

Guy Laforest

With the collaboration of Oscar Mejia Mesa

\section{Interpreting Quebec's Exile Within the Federation}

\section{Selected Political Essays}

« Diversitas »

vol. 20 
This publication has been peer-reviewed.

(C) Guy Laforest, 2014

P.I.E. Peter Lang SA

1 avenue Maurice, B-1050 Bruxelles, Belgique

www.peterlang.com; info@peterlang.com

ISSN 2031-0331

ISBN 978-2-87574-229-2

eISBN 978-3-0352-6488-3

$\mathrm{D} / 2014 / 5678 / 109$

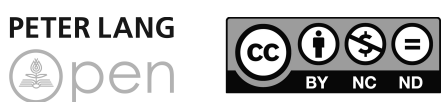

Open Access: This work is licensed under a Creative Commons Attribution Non Commercial No Derivatives 4.0 unported license. To view a copy of this license, visit https://creativecommons.org/licenses/by-nc-nd/4.0/

CIP available from the Library of Congress USA, and the British Library, GB.

Bibliographic information published by "Die Deutsche Bibliothek"

"Die Deutsche Bibliothek" lists this publication in the "Deutsche Nationalbibliografie"; detailed bibliographic data is available in the Internet at $<\mathrm{http}: / / \mathrm{dnb}$.de $>$. 


\section{Contents}

Acknowledgements .............................................................................. 11

\section{Introduction}

Interpreting Québec's Exile within the Federation: Selected

Political Essays, by Guy Laforest with the collaboration of Oscar Mejia Mesa.

Chapter 1

The Internal Exile of Québecers in the Canada of the Charter ......21

I. Pierre Trudeau, the Exile of Québecers, and the Charter............ 22

II. To End the Exile....................................................................... 25

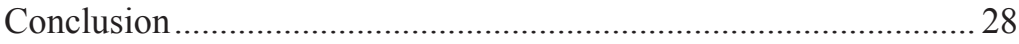

Chapter 2

The Contemporary Meaning and Utility of Federalism.................... 31

I. The Meaning and Utility of Federalism...................................... 32

II. Federalism's Challenges and Problems ...................................... 34

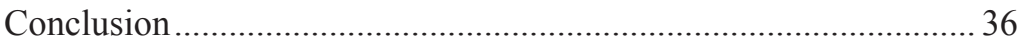

Chapter 3

Making Sense of Canada as a Federal System: The Relevance

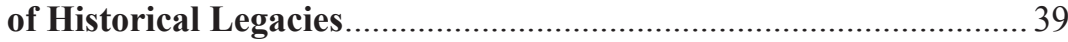

I. Historical Legacies: Their Nature, Role, Interrelations, and Contemporary Significance.................................................. 43

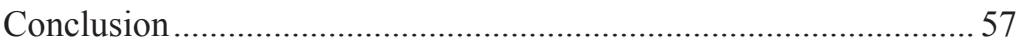

Chapter 4

The Historical and Legal Origins of Asymmetrical

Federalism in Canada's Founding Debates: A Brief

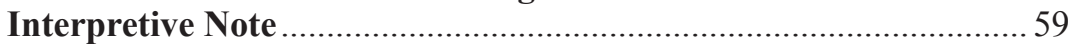

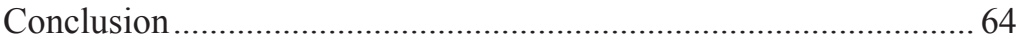

Chapter 5

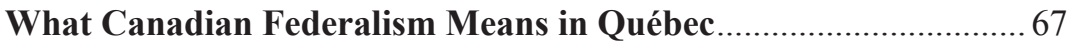

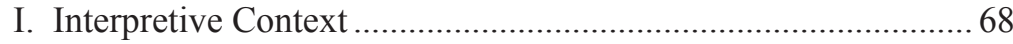

II. Contemporary Trends and Scholarship: Critical Reflections ..... 72

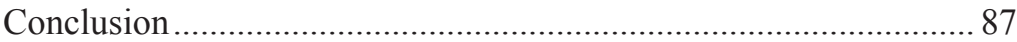


Chapter 6

Lord Durham, French Canada, and Québec: Remembering the Past, Debating the Future

I. Coming to Terms with Lord Durham's Report in French Canada and Québec

II. Janet Ajzenstat's Introduction: Debating Lord Durham's Influence on Canada and Assessing Him as a Human Being and as a Thinker

III. A Critical Hermeneutics for the Present and for the Future.

Conclusion 108

Chapter 7

Some Reflections on the Bouchard-Taylor Commission

Chapter 8

More Distress than Enchantment: The Constitutional Negotiations of November 1981

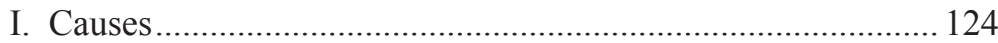

II. Assessing the Behaviour of Participants.................................. 126

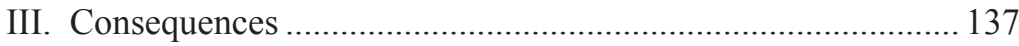

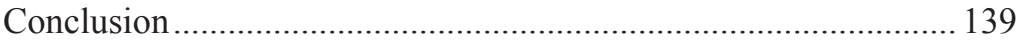

Chapter 9

The Canadian State and the Political Freedom of Québec: The Ideas of James Tully and Michel Seymour

I. Canada's Political-Constitutional Identity and Québec's Situation

II. The Philosophical Approaches of James Tully and Michel Seymour.

III. From a Straightjacket to a Reworking of Democratic Constitutionalism with Universal Scope

IV. Michel Seymour's Criticism.

V. Overall Consideration of the Theses in Light of Seymour's Objections

Conclusion 168 


\section{Chapter 10}

Trust and Mistrust between Harper and Québec .......................... 171

I. Some Reflections on Trust and its Derivatives ......................... 171

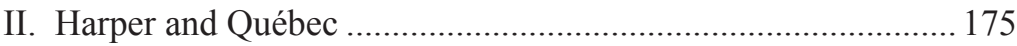

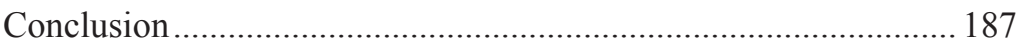

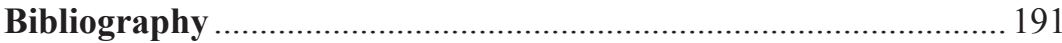





\section{Acknowledgements}

This book owes a lot to the Groupe de recherche sur les sociétés plurinationales (GRSP), led by my colleague and friend Alain-G. Gagnon at the Université du Québec à Montréal. This research group, founded in 1994, currently includes the following colleagues: Eugénie Brouillet, Dean of Law, and Jocelyn Maclure, from the Faculty of Philosophy, at my host institution Université Laval; Dimitri Karmis, André Lecours, and François Rocher from the Écoles d'études politiques (School of Political Studies) at the Université d'Ottawa; José Woehrling, from the Faculty of Law at the Université de Montréal; Geneviève Nootens, from the Département de sciences humaines (Department of Human Sciences) at the Université du Québec à Chicoutimi; and, James Tully, from the Department of Political Science at the University of Victoria. The GRSP has had various grants over the years from the Social Sciences and Humanities Research Council of Canada and from the Fonds de recherche du Québec - Société et culture. These grants have been instrumental for researching and writing many of the chapters found in this book. I am grateful to both granting agencies. I have also benefited from the support of my own institution, through the Aid to Publication Program of the Faculté des sciences sociales at l'Université Laval. I also want to express my thanks for this support.

As this book's front page suggests, I have benefited immensely from the support of Oscar Mejia Mesa, one of my doctoral students, who read all chapters and made many suggestions in both form and substance. This book would not have seen the light of day without him. I also wish to thank Marc Woons, FWO doctoral fellow with the Institute of Philosophy at the University of Leuven, for an insightful linguistic revision and for his many substantive suggestions.

I wish to warmly thank Alain-G. Gagnon for welcoming my work into this collection. His generosity at key moments has been decisive for me.

As always, thanks to my wife Andrée Lapointe and to my three children Isabelle, Vincent, and Raphaël, who make me a happy person.

Guy Laforest 



\section{INTRODUCTION}

\section{Interpreting Québec's Exile Within the Federation}

\section{Selected Political Essays}

I often repeat, half-seriously, that I am a historian of ideas and a teacher of political philosophy, hidden in a political science department. At all Québec universities, as in the rest of North America, much of the business of political science has to do with positivistic approaches, quantitative methods, and rational choice theories for explaining social behaviour. Within the discipline, I belong to the minority methodological and epistemological position. To make sense of politics, I believe one has to rely on an interdisciplinary approach. The insights of philosophy, history, literature, sociology, and law can all enrich the search for coherent and meaningful interpretations of political events, phenomena, and doctrines. Such a combination forms the spirit or, as the Germans say, Geist of a humanistic approach to the study of politics. This book is one example of doing political science in such a way, applied to the task of interpreting the situation of Québec and of Québecers within the Canadian federation.

The book belongs squarely to the discipline of political science with chapters studying the theory and practice of Canadian federalism, as well as analysing various aspects of nationalism in Québec. It borrows heavily from the domain of constitutional law in chapters dealing with Canada's fundamental laws of 1867 and 1982. Intellectual history has always fascinated me, and I hope that readers who share my interest will appreciate the chapters that deal with the figures such as Lord Durham, Gérard Bouchard, Charles Taylor, James Tully, and Michel Seymour. For those who prefer sociology and philosophy, the book contains chapters on political and social integration, trust and mistrust, political freedom, and complex equality. Internal exile, distress, and enchantment are also of course literary notions, and such ideas play a central role in my reflections.

Much of Western civilization would continue to exist if Québec and Canada were obliterated from the surface of the earth. Our political existence thus takes place at the margins of History and at the periphery of dominant nation-states such as the United States, France, Germany, and the United Kingdom. I nevertheless believe that our political history, with its drama and its problems, can inform political science as a discipline and the international community's learned public sphere. For thirty years, I 
have lectured about this history and about these lessons at most universities in Québec and across Canada. Even in our current circumstances of growing indifference between our societies and scholarly communities, I believe that the conversation must be sustained and that efforts must be made to bridge gaps in our reciprocal understandings. The essays brought together in this book represent another personal effort towards attaining this goal.

The first chapter explains its title and goes to the heart of the situation facing Québecers and their place within the Canadian federation. In 1954, Maurice Lamontagne, the late Canadian senator and Université Laval economist, argued that Québec's situation within Canada is hybrid and ambiguous (Lamontagne 1954). Sixty years later, his reflections still make sense. Geography and the fundamentals of the Canadian constitutional framework are here to stay. Nevertheless, Québec remains awkwardly integrated into the country as a whole. Québec as a political community, and Québecers as citizens and political actors, thus seem to me to be in a situation of internal exile. After explaining at greater length what this notion entails, I attempt to identify the precise changes that could be made to the Canadian Charter of Rights and Freedoms to remedy this situation. The first time I evoked this idea, a few years ago at a Trudeau Foundation event in Winnipeg, some civil servants from the federal Department of Justice told me that it was the first time, in a couple of decades, that they had heard such specific suggestions. I believe that Québec's self-representation as an intercultural nation should be affirmed in the Charter's core. It should also be used as an interpretive principle linked to the understanding of the concept of reasonable limits to rights and liberties in the first section of the Charter, in its linguistic regime (sections 16 to 23), and, finally, in its disposition related to promoting the multicultural heritage of Canadians.

My ideas concerning the contemporary challenges and utility of federalism are straightforwardly presented in the second chapter. I revised these pages in the weeks following the death of Richard Simeon, one of Canada's preeminent scholars of federalism, who passed away on October 11, 2013. He will be sorely missed. In both of Canada's official languages, with rigour, subtlety, and respect for dissent, Simeon spent forty years putting his brilliant mind to the task of researching the theory, practice, and machinery of federalism in Canada and the world. $\mathrm{He}$ promoted the virtues of dialogue and reciprocal understanding. He played an instrumental role in developing the language of trade-offs in the relationships between Anglophones and Francophones and between Canada's and Québec's national projects. In the coming years - and in particular at a colloquium taking place in mid-October 2014 in Québec 
City commemorating the $150^{\text {th }}$ anniversary of the Québec Conference of 1864 that led to the Dominion of Canada three years later, which is being organized by Eugénie Brouillet (the Dean of Law at Laval), Alain-G. Gagnon (UQAM Political Scientist), and myself - we hope to have many opportunities to pay homage to Simeon's work. ${ }^{1}$ We often debated the fact that, although I believe that he was right in arguing that provinces profit from high legal, political, jurisdictional, fiscal and bureaucratic capacity, our political system nevertheless remains highly centralized mostly in the organization and management of intergovernmental affairs and in the workings of the judicial branch of government. We last discussed these matters at a conference organized in 2011 by Michael Burgess and Cesar Colino at Howfield Manor, near Canterbury, on the English soil where he was born. The topic of the conference dealt with historical legacies crucial to understanding federal regimes - the topic of the third chapter.

In 1998, the Supreme Court of Canada, in its Reference re Secession of Québec, made an insightful contribution to the discussion concerning Canada's most important historical legacies. It suggested that our political and constitutional order has four foundational principles: federalism, democracy, constitutionalism and the rule and law, and respect for the rights of minorities. Readers will find a deeper analysis of the Supreme Court's judgment in a later chapter of this book interpreting the ideas of James Tully and Michel Seymour. Although I would never deny the Supreme Court's authority, I propose a supplementary reading on the topic of historical legacies in the third chapter. First, I identify various dimensions of Canada's past and present British heritage. I then attempt to delineate the idea of the centrality of the state for the development of an original national project, in the shadow of the United States. Hopefully, readers will agree that I talk about the same country as the Supreme Court. They will also note some nuances and differences. In agreement with the Supreme Court, I recognize that federalism, or the principle of autonomy, represents one of Canada's key historical legacies. However, contrary to the Supreme Court, I do not believe that, either at the time of the founding or later on in the evolution of the country, it has ever been the equivalent of the Star of Bethlehem guiding our political leaders. On the topic of federalism in Canada, I also discuss the various tensions and interpretive prisms that were central to Simeon's scholarly endeavours.

\footnotetext{
The colloquium's program can be downloaded at the following internet address: http:// www.conferencedequebec.org/. The colloquium belongs to the research program of the Groupe de recherche sur les sociétés plurinationales, whose scientific director is Alain-G. Gagnon at the Université du Québec in Montréal. The colloquium is sponsored by the Government of Québec's Secrétariat aux affaires intergouvernementales canadiennes (SAIC).
} 
Finally, and hopefully less obliquely than the Supreme Court, I examine the Janus-faced dimensions of Québec for the Canadian national project. In my judgment, it is crucial never to forget that Québec simultaneously reassures and threatens the very idea of a distinct and united Canada. This leads me to explore the topics of English-French duality in Canada and of the centrality of the state for Québec in the pursuit of its own national project.

Astute political leaders and thinkers can make these national projects compatible. I argue in the fourth chapter, discussing the historical and legal origins of asymmetrical federalism in and around the British North America Act, 1867 (now the Constitution Act, 1867), that our founders possessed such astuteness. Meeting at Brock University in the spring of 2014, under the presidency of my colleague and friend Alain Noël from the Université de Montréal, the Canadian Political Science Association organized a panel on the ideas of Janet Ajzenstat, whose work in political theory and constitutional history is indispensable to understanding the spirit of our founding (Ajzenstat 2014). The Canadian political experiment is linked to a complex issue that has long troubled Ajzenstat: the question of whether or not liberal universalism can be reconciled with particularism (see, also, Ajzenstat 1999; LaSelva 1995; Burelle 2005; Noël 2006). I lay the historical ground for attempting to answer this question with regards to Québec's situation within Canada.

If the federal principle played a significant part in the advent of the Dominion of Canada in 1867, it has had a complex and storied evolution in Québec throughout the $20^{\text {th }}$ century (see Gagnon 2009; Karmis and Rocher 2012). Many people, including myself, have lamented the disengagement of Québec from Canada over the last decade. Chapter five examines the renewed interest in the study of federalism in Québec at the start of the $21^{\text {st }}$ century. It is only fair to recognize the leadership of André Pratte, chief editorialist at La Presse, in this endeavour (Pratte 2007). ${ }^{2}$ This chapter discusses the writings of various historians, philosophers, political scientists, and legal experts such as Eugénie Brouillet, Alain Noël, Jean Leclair, François Rocher, Alain-G. Gagnon, Michel Seymour, Marie-Bernard Meunier, Pierre-Gerlier Forest, Stéphane Dion, and André Burelle. I owe a great deal to another colleague and friend, François Rocher, who, like Simeon (who repeated the argument at various conferences sponsored by the Forum of Federations), believes that in complex federations scholars of federalism from the majority nation tend

\footnotetext{
André Pratte played a key role in creating a new think tank on federalism in Québec called L'idée fédérale/The Federal Idea. He remains its president. See their website at the following internet address: http://www.ideefederale.ca/index_a.php.
} 
to favour the goal of unity and the strategy of integration, while scholars from the minority nation favour the goal of autonomy and the strategy of empowerment (Rocher 2009, 121).

The next chapter is an attempt to come to terms with the emblematic historical figure of Lord Durham. A first version of this text was prepared for the re-edition of the Durham Report by McGill-Queen's University Press under Janet Ajzenstat's leadership in 2007. After summarizing Lord Durham's personal trajectory and political thought, I reassess the evolving interpretation of his famous report in French Canada and Québec. One finds here at work the twin poles of my approach to the study of politics, combining intellectual history with political theory to create a dynamic of reciprocal enrichment and elucidation. For a good many years, at the Université Laval, my courses on nationalism included a comparative section devoted to examining and comparing the case of Québec with those of Scotland and Catalonia. This remains highly relevant in light of Scotland's referendum on independence being held on September 18, 2014 and the continuous deterioration of the relationships between the Spanish and Catalan national projects. However, interpreting the Durham Report has led me to explore new comparative horizons in Central and Eastern Europe, looking at how the cases of Poland and Hungary, among others, relate to nationalism in Québec. In all these cases the central challenge remains, repeating the apt formula of the late French philosopher Paul Ricoeur, constructing a just and happy national historical memory. This must be done in a critical manner, simultaneously keeping at a fair distance the sirens of post-nationalism and of anti-nationalism. In these matters, interpreting the Durham Report will always be a test and a crucial task.

The seventh chapter of the book takes stock of the Bouchard-Taylor Commission and its final report entitled Building the Future: A Time for Reconciliation (Bouchard and Taylor 2008). In 2007-2008, the Commission explored key issues related to managing diversity in Québec, concentrating on the relationships between the French-Canadian majority's heritage and that of religious and cultural minorities. This work is obviously related to the more recent debate on the adoption of a Québec Charter of Values, introduced in the late summer of 2013 by the former Parti Québécois government led by Pauline Marois. There is no doubt in my mind - a rare occurrence - that the task of defining political judgment in Québec, on difficult matters related to integration and the place of religion in the public sphere, consists in finding balance between consideration for our particular situation in North America, on the one hand, and the ideals of justice and the principles of liberal democracy, on the other hand. I belong to a family of thinkers who argue that such is the leitmotif 
of Québec's entire historical trajectory (see Gagnon 2011; Létourneau 2006; Thériault 2002). I try to go beyond the Report to understand its place in the intellectual evolution of each of its two co-presidents, Gérard Bouchard and Charles Taylor.

If it does make sense to characterize the situation of Québec and its citizens within Canada as a form of internal exile, this has much to do with the constitutional negotiations of November 1981, which led to the patriation of the Constitution in 1982. I have written extensively about this but, to reassure the readers, I hope I am doing it in an original way in the eighth chapter of this book (Laforest 1995a). Relying substantially on the writings of André Burelle, one of Pierre Elliot Trudeau's former advisors and speechwriters, whose works should be translated into English and published, I first explore the causes and consequences of those fateful events of 1981-1982. With Burelle's help, I try to provide a better grasp of Trudeau's role and his various motivations during the whole affair. So far, one could say, there is nothing particularly new here. I do enter new ground in evaluating René Lévesque and his Parti Québécois government's share of responsibility for events that took place between 1976 and 1985. In a previous book, I established a comparison between the rebellions of 1837-1838, considered as the failed rebellions of an imperial age, and the referendums of 1980 and 1995, seen as the failed rebellions of a democratic era (Laforest 2004, 332-333). Over the long run, I view this pattern as a tragic dimension of our history. From La Fontaine to Cartier, between 1841 and 1867, many rebels of 1837-1838 were able at least to attenuate (in the mind of pessimists), and possibly also bypass (in the mind of optimists), the consequences of our failed $19^{\text {th }}$ century rebellions. If the Meech Lake Accord had seen the constitutional light of day, at any moment between 1987 and 1990, I surmise that we would have entered into a similar dynamic. In contemporary Québec, could political figures such as the new premier, Philippe Couillard, and the leader of the Coalition Avenir Québec, François Legault, play roles similar to those of La Fontaine and Cartier in the $19^{\text {th }}$ century? As I write these lines in early May 2014, I have not completely abandoned all hope for such changes during my lifetime. Of course, with regards to interpreting our key constitutional struggles, I recognize that all this remains open to debate. I claim no imperial interpretive authority (for related views, see Gagnon 2011; Webber 1993; LaSelva 1995; Millard 2008).

Beyond the horizons of politicians, historians, legal scholars, and political scientists, the last decades have also seen philosophers do their fair share to understand Québec's quest for greater political freedom within Canada's constitutional order. James Tully, formerly from McGill and now teaching at the University of Victoria, and Michel Seymour, from the Université de Montréal, are two of the most prominent and rigorous 
of these philosophers. The ninth chapter explores the issue of Québec's freedom within Canada. Tully (with Charles Taylor) supervised my thesis at McGill and I cannot overstate the size of my debt to him. ${ }^{3}$ Seymour is one of the most brilliant and sympathetic colleagues of my generation, and I consider his book on toleration and recognition to be the best political theory book written by either a Québecer or by a Canadian in the $21^{\text {st }}$ century. Both remain my friends. In looking at their work, I ask whether the Canadian constitution is a straightjacket for Québec. How should we integrate recent Supreme Court jurisprudence into any discussion of these matters? Does the Clarity Act make a difference? Tully has in many instances attempted to answer at least some of these questions, and Seymour has been quite critical of Tully. I discuss their respective views before moving on to some conclusions of my own.

When I started teaching political science at the University of Calgary almost thirty years ago, Stephen Harper was a graduate student in the Department of Economics where he was already quite involved in Canadian politics. During my stay in Calgary, he worked hard, with others, to found the Reform Party in 1987. In 2014, after almost a decade in power, he stands as the most powerful and successful Canadian politician of the early $21^{\text {st }}$ century. In the book's tenth and last chapter, I explore the uneasy relationship between Harper and Québec, which hovers between various shades of trust and mistrust. Considering the hopes that existed during the years characterized by Harper's open federalism (or, better put, federalism of openness) between 2005 and 2007, it is understandable that the current Prime Minister should feel disappointed with the performance of his party in Québec. However, as I argue in the chapter, there have been many collisions between Harper and successive Québec governments on policy matters over the last few years. Moreover, Québecers do not seem to be very influential in his inner circle, with the current exception of Denis Lebel, his Québec lieutenant. What should Harper do for Québecers and Québec authorities so that they trust him more? I cannot speak for others, so I only speak for myself. In late November 2006, the House of Commons passed a motion, presented by Stephen Harper, stating "that this House recognize that the Québécois form a nation within a united Canada". ${ }^{4}$ The use of the French word, Québécois (instead of the English equivalent, Québecers or Québeckers), systematically used by

3 In late April 2014 in Montréal, the Groupe de recherche sur les sociétés plurinationales organized, under the leadership of Dimitrios Karmis (Université d'Ottawa) and Jocelyn Maclure (Université Laval), a major conference on Tully's political thought: http://www.evenements.uqam.ca/?com=detail\&eID=414436.

4 See the $C B C$ News (2006) story entitled "House passes motion recognizing Québécois as nation." 
Québec governments when it addresses itself to all citizens of Québec notwithstanding their origin, represents, in my judgement, an indirect attempt to reduce the population concerned to those of French-Canadian ethnic descent, as was frequently done at the peak of our constitutional struggles by those who advocated the partition of a sovereign Québec and its reduction, essentially, to the North Shore of the Saint Lawrence River between Baie-Comeau and the east end of the Island of Montréal. ${ }^{5}$ If Harper meant to recognize all of us living in Québec as part of the Québec nation, he should say so explicitly.

5 For a similar argument, see Bercuson and Cooper (2002). The first edition of this book was published in 1991. Bercuson and Cooper teach at the University of Calgary, and, like Harper, they belong to the intellectual vanguard of the new conservatism that came from Western Canada in the 1980s. To the best of my knowledge, Harper has never clearly said who exactly he wanted to recognize in 2006 . He should. The harsh tone of Bercuson and Cooper has not disappeared from our public sphere. Conservative guru Brian Lee Crowley also writes in the spirit of their Deconfederation essay. See one of his recent opinions in the Postmedia Network at http://www.macdonaldlaurier.ca/ crowley-in-the-citizen-toward-greater-clarity-on-Québec/ 


\section{CHAPTER 1 \\ The Internal Exile of Québecers in the Canada of the Charter}

I begin this chapter on a personal note. More than thirty years ago, when the Canadian Charter of Rights and Freedoms came into effect, I was living in Montréal and studying at McGill University. Among my professors were two great intellectuals who were also great idealists, Charles Taylor and James Tully. ${ }^{1}$ I learned much from them, and, over time, they became friends. Other professors influenced me perhaps less directly though just as meaningfully, namely Blema Steinberg, Daniel Latouche, James Mallory, and Harold Waller. Their approach was tinged with realism, which perfectly supplemented Taylor and Tully's approach. In philosophy, the realist approach is that of liberalism without illusions as expounded by Judith Shklar, Raymond Aron, Isaiah Berlin, and Karl Popper. In politics, according to these authors, one must first and foremost avoid the worst and must understand that cruelty, fear, terror, and violence can crush a person and attack his or her dignity and privacy. In this respect, I share the judgment of Irvin Studin, who wrote that Canada is a tremendous success on the scale of humanity. As a country, it is among the most "peaceful, just and civilized" (Studin 2006, 184). A country where, to add my own voice, the strong as well as the weak can sleep soundly in a decent, comfortable, and humane social environment without fear of the worst. All of this counts, therefore, as a tremendous development in the history of humankind.

I start on this note because I want to provide a sense of proportion for the analysis that will be developed regarding the internal exile of Québecers in the Canada of the Charter. Like a number of other people in Québec, in terms of political identity and belonging, I am not a happy citizen in the Canada of the Charter (see Burelle 1994; Dufour 2000). Beyond my personal feelings, I think this is explained by the fact that Québec is not properly integrated into the new Canada that has arisen since the constitutional reforms of 1982. Paradoxically, these reforms saw the light of day, to a large extent, due to the dynamism and pressure

For other analyses inspired by Taylor and Tully, see Gagnon (2007) and Laforest (2004). 
exerted by Québec on Canada in the aftermath of the Quiet Revolution. This chapter will argue that instead of improving the situation, the 1982 constitutional reforms worsened it and resulted in the internal exile of Québecers within the Canada of the Charter. The term internal exile describes very well the basis of my thoughts - someone who is exiled from the inside is someone who feels uncomfortable and who lives like a stranger in his or her own country.

This chapter is divided into three sections. The first section argues that the first thirty years of the Charter led to the exile of Québecers within Canada. The Trudeau vision of the constitution embraced Canadian sovereignty as the means of challenging Québec nationalism and this led to the end of the Canadian dream that was created through the Confederation of the British North American colonies in 1867. The second section contends that the exile of Québecers can be ended by amending the Canadian Charter of Rights and Freedoms to recognize the distinct status of Québec within section 1 , the reasonable limits clause, and section 27 , the interpretive clause that requires the Charter to be applied in a manner consistent with Canada's multicultural heritage. The final section reflects on the Charter's virtues, concluding that its implementation without the consent of the Québec National Assembly represents, to invoke Donald Smiley (1983, 78, 90), a dangerous deed - one that led to the internal exile of Québecers within Canada in the era of the Charter and that continues to be a fundamental obstacle to Canada being a just federal society.

\section{Pierre Trudeau, the Exile of Québecers, and the Charter}

And once again, it means an even greater tendency, a greater weight on the side of provincialism, at the expense of a federal institution or legislation which, up until now, has given Canadians a feeling of belonging to one Canada. In the same way, the Canadian Charter of Rights and Freedoms was important to Canadian unity, as were the patriation of the Constitution and the new Canadian flag. All of those things are important in the sense that they help Canadians to realize that they share with all other Canadians, throughout the country, the same set of fundamental values (Trudeau 1990a, 31).

The internal exile of Québecers is made immensely more complex if we add the dominant role played by Pierre Elliott Trudeau, undoubtedly one of the greatest political figures of Québec and Canada in the $20^{\text {th }}$ century. In terms of belonging and identity, Québecers were to some extent exiled by one of their own. Federalism held an important position in Trudeau's life, except that a study of his actions and writings in the 1980s, juxtaposed against the overall horizon of his political-intellectual life, reveals him to be a nationalist and a Canadian sovereigntist more 
than a federalist. This is clearly illustrated in an important book that André Burelle (2005), philosopher and at one time a speechwriter for the former prime minister, devoted to Trudeau's work. I will return to Burelle's analysis in a moment.

At the end of his career, Trudeau dreamed of cementing once and for all the sovereignty of both the Canadian nation and the central government. In the debate over the Meech Lake Accord, he often wondered: "How do you make a country stronger by weakening the only government that can talk for all Canadians?" (Trudeau 1990b, 94). Rather than trying to find in federalism and its institutions a balance between a design for a Canadian nation and a Québec nation, he decided after the 1980 referendum to resort to Canadian nationalism to change the country and to prevail over Québec sovereigntists definitively. ${ }^{2}$ The Charter of Rights and Freedoms was the instrument of such a plan, as political scientist Alan Cairns recalled in an interview with the historian Robert Bothwell:

The prime one, the obvious one, is what the Charter appears to be on its face, a way of protecting citizens' rights against the state. From Trudeau's perspective, however, the much more important goal was the attempt to generate a national identity, and this really meant an attack on provincialism. It was a way of trying to get Canadians to think of themselves as possessors of a common body of rights independent of geographical location, which would constitute a lens through which they would then view what all governments were doing. So it was really a de-provincializing strategy, primarily aimed at Québec nationalists, but also at the general centrifugal pressures that were developing across the federal system (Bothwell 1995, 180).

In his 2005 book, Burelle lucidly explains the political events of 1980 that led Trudeau to break the delicate balance that had previously prevailed in his mind between, on the one hand, the community-minded personalism of the Citélibrist period or the views of Jacques Maritain and Emmanuel Mounier that were reconcilable with the federalism of 1867 and a certain acceptance of the difference of the Québec nation and, on the other hand, an ultra-individualist and symmetrical liberalism making the case for Canadian nation-building (Burelle 2005, 68-70). In the spirit of Burelle, the "one nation" federalism of the Constitution Act, 1982, draws upon republican unitarism and starts from the premise of an individualistic and anti-communitarian liberalism. According to Burelle, this is operationalized in the following manner. First, all individuals are brought into a single civic nation, which delegates to the federal parliament the entirety of its national sovereignty. Invested with this sovereignty, the

$\overline{2}$ See also Laforest (1992) and Laforest (2004: 219-236). 
central Parliament then entrusts the provinces with the functional powers better exercised by them (Burelle 2005, 459).

What kind of federalism flows from such logic? According to Burelle, a federalism that does not respect Québec's difference and disregards the principle of non-subordination between two levels of government, both sovereign in their respective jurisdictions. In other words, a federalism that moves away from what the founders of the Canadian federation wanted to build in 1867. Burelle feels that the spirit of 1982 flouts that of 1867 through the intersecting operation of the following principles:

- The practice of a misguided subsidiarity, i.e., devolution of downward sovereignty (top-down) from the central government;

- The existence of a senior "national" government and junior "provincial" governments;

- The granting to Ottawa of the right to intervene to ensure "the national interest" in areas of provincial jurisdiction;

- The identity of law and treatment of individuals and provinces merged within a single, republican nation (Burelle 2005, 459).

On the whole, Burelle's interpretation strikes me as reasonably fair to Trudeau's intentions. However, he said this somewhat differently in his 1994 book when he spoke of government by judges via a "national charter" and a government by the "Canadian people," enabling Ottawa to circumvent the division of powers (Burelle 1994, 64). However, I would introduce an important nuance to this argument. A distinction must be made between Trudeau's vision of the Charter and the actual content of the document.

I think Burelle understands Trudeau and his vision of the Charter better than the content of the Charter, since the document is not simply limited to individual rights. There is room in the Charter for the multicultural heritage of Canadians and for the collective rights of Aboriginal peoples. However, there is no room for the idea of distinct treatment for Québec and for the principles that should flow from the legal consequences of this difference. Before exploring the means that might bring an end to the internal exile of Québecers in the Canada of the Charter, I conclude here with two analyses in the spirit of 1982 by Eugénie Brouillet and José Woehrling, two of the best public law professors in Québec today.

According to Brouillet, the Charter cannot accommodate Québec's differences because judicial review in a federal system results in centralization:

It is precisely because of the Canadian Charter's potential to integrate that the federal government made it the cornerstone of the constitutional reform of 1982. On the political level, the recognition of super-legislative rights and 
freedoms for all Canadian citizens would form the basis of their common identity and strengthen the unity of the Canadian nation (Brouillet 2005, 325).

This position is supported by Woehrling, but in a more indirect manner. Woehrling argues that human rights projects are used by the majority culture to regulate the activities of minority groups within a federal state:

To the extent that the protection of rights by a constitutional instrument is an anti-majoritarian tool, it limits the political autonomy of minorities who have one or more territorial entities. The minority who controls such an entity sees its political power restricted to its own minorities and its own members [...] The majority at the national level could give in to the temptation to use its power to impose on its minority the respect for excessive guarantees for the benefit of the minority 'within the minority.' One has the impression sometimes that the majority group at the national level defends its own interests under the pretext of human rights and minority rights (Woehrling 2005, 115).

\section{To End the Exile}

Although Québec's exile still persists, it is only fair to acknowledge a number of positive outcomes for Québec in Canadian politics, mostly between 2004 and 2008: the asymmetrical Canada-Québec Health Agreement signed in 2004 by the governments of Paul Martin and Jean Charest; Stephen Harper's declaration of the doctrine of open federalism during the January 2006 electoral campaign that led to the election of a Conservative government in Ottawa; the Harper-Charest Agreement in May 2006, accepting the principle of a special international role for Québec and incorporating a representative of the Government of Québec into the Canadian delegation to UNESCO; the House of Commons resolution in November 2006 stating that the Québécois form a nation within a united Canada (despite the ambiguities that persist between the English and French versions of the text); and, finally, addressing the fiscal imbalance during the February 2007 federal budget (Laforest and Montigny 2005, 364-368). ${ }^{3}$

In my view, there is no doubt that these developments helped alleviate the discomfort and changed the climate in which our political life operates. They do not, however, take into account the issue of Québec's place in Canada's constitutional architecture. To make progress in that direction, one has to amend the Constitution Act, 1982 and the Canadian Charter of Rights and Freedoms. The first section of the Charter states that rights are "subject only to such reasonable limits prescribed by law as

3 See, also, Banting et al. (2006), particularly Alain Noël's chapter (2006, 25-37). Likewise, see Murphy (2007) and Gagnon (2009). 
can be demonstrably justified in a free and democratic society." Because the Supreme Court recognized federalism as the primary arrangement of the Canadian political community and the main normative pillar of our constitutional structure in the Reference re Secession of Québec, an amended section 1 of the Charter should refer to a "free and democratic federation" rather than a "free and democratic society." This small change should have two major effects. First, it should instruct judges of the need to seriously consider the neuralgic nature of the federal principle in their understanding of the rules that govern our legal system. Second, it should have educational value, inviting the public to better understand the importance of federalism in the Canadian political identity. This action would additionally result in Québecers feeling less alone in taking federalism seriously in their understanding of Canada!

The second change that I propose flows logically from the debate that marked Canadian public life in the fall of 2006 - the desirability of recognizing the Québec nation. Launched by Michael Ignatieff during his candidacy for the leadership of the Liberal Party of Canada, the debate ended with a modified motion presented by Prime Minister Harper in the House of Commons that recognized the Québécois as a nation within a united Canada. To truly end the internal exile of Québecers, we need to place their way of defining themselves in a text that really matters to Canadians, the Canadian Charter of Rights and Freedoms. Section 1 of the Charter could be amended to recognize that Québec forms a distinct society in Canada, as well as explicitly stating that the Government of Québec and the National Assembly are obligated to protect and promote Québec as a distinct society. This is the phrase that was preferred by Claude Ryan and André Laurendeau during the proceedings of the Royal Commission on Bilingualism and Biculturalism fifty years ago.

Some would suggest that this proposal represents the ghost of the distinct society clause from the failed Meech Lake Accord. They are not wrong. Many Québecers see the Charter of Rights and Freedoms - and principally section 1 - as an attempt to create a single great Canadian nation that incorporates all other affiliations, particularly those flowing from modern Québec nationalism. In this respect, the adoption of the Meech Lake Accord would have rectified the issue and thus the internal exile of Québecers. One day the question will resurface and it will be part of the constitutional doctrine of a future Québec government. It is interesting to recall, on the issue of the distinct society clause and its recognition, what Stéphane Dion, former leader of the Liberal Party of Canada, said when he was part of Jean Chrétien's cabinet in 1996:

What is the essence of the distinct society clause? This provision would be a section for interpretation, similar to section 27 of the Charter of Rights and 
Freedoms, which recognizes multiculturalism. It guarantees that in the grey areas of the Constitution, in areas where it is necessary to interpret the rules, the Supreme Court will take into account the distinct nature of Québec in areas such as language, culture and civil law. This will be a useful clarification, but one that would not alter the division of powers under the Constitution. This is not a request for special status or unique privileges (Dion 1996, B7).

Since the era of British rule in the late $18^{\text {th }}$ century, we have rejected policies of assimilation and homogenization that generally dominated the period of consolidating the modern nation-state in Europe. The Québec Act of 1774 guaranteed Her Majesty's new subjects of French origin religious freedom and the maintenance of their civil law. ${ }^{4}$ When Canada became a federal Dominion in 1867, a similar spirit of openness, recognition of diversity, and respect for minority rights was expressed in the division of powers. Provinces were provided jurisdiction over property and civil rights, and there were sections protecting religious minorities. This was clearly a demand not only from Canada East - Québec's former name - but also from other British North American colonies that entered Confederation in 1867. It is quite possible to trace the historical and legal origins of asymmetrical federalism in Canada to the wording of section 94 of the Constitution Act, 1867, which omitted Québec from the harmonization of laws related to property and civil rights between the federal government and the common-law provinces during Confederation (i.e., Ontario, Nova Scotia, and New Brunswick). ${ }^{5}$ This Canadian originality in the history of the modern nation-state was notably expressed in 1982 in section 27 of the Charter, which stipulates that "[t]his Charter shall be interpreted in a manner consistent with the preservation and enhancement of the multicultural heritage of Canadians."

The third change that could put an end to the internal exile of Québecers in the Canada of the Charter deals with section 27. If the debate on the Québec nation has raised significant interest in the country's English and French media, just as much can be said for the work of the Consultation Commission on Accommodation Practices Related to Cultural Differences, which was co-chaired in the province of Québec by Gérard Bouchard and Charles Taylor, and whose report is analysed in chapter seven. This history has accelerated in the second half of the $20^{\text {th }}$ century and will not change. I believe that this social phenomenon is good and that it honours all of the people who live in Canada and who have had to confront this troubled world of ours. However, I also believe that, in its portrayal of the rights and obligations that flow from section 27 regarding

For a philosophical view, see Tully (1999, 142-145).

See Ajzenstat et al. (2004, 336-337, 378). 
the multicultural heritage of Canadians, the Charter misses a fundamental reality, namely that this heritage is embodied in Canada and the institutional networks of two host societies. In addition to the Canadian society, there is a Québec host society that happens to affirm the predominance of the French language. Section 27 should reflect the duality of host societies in Canada. Clarifying section 27 of the Charter strikes me as being essential for the fair and stable integration of Québec in Canada today.

Canada is a free and democratic federation integrating Québec's distinct national society and a multicultural heritage embodied in two host societies of which one lives mainly in French. This is what is lacking in the Canadian Charter of Rights and Freedoms, if I understand the situation, in order to go beyond the political alienation of Québecers. Such changes would not end political conflicts in the Canadian federal system, including those between Québec and its Confederation partners. Those who want to put an end, once and for all, to "political-constitutional squabbles" forget that political life will always be a matter of dialogue and debate that may lead to clashes. However, such changes would have the effect of healing an injury and restoring confidence in the Constitution as higher law and in Canadian institutions. I willingly admit that the perspective chosen for analysis in this chapter is far from exhausting the totality of reality. As Catalans and many federated states of the world have done, Québecers could also demonstrate daring and imagination by acquiring, in an autonomous manner, an internal constitution strengthening the backbone of its societal institutions (Laforest 2004, 256). Finally, Québecers more confident in their future and better integrated should be more open to the desire for change by other Canadians, which is certainly just as legitimate as their own desire. Québecers, who are no longer internally exiled, should be capable of proclaiming, in their own way, their allegiance to Canada and of engaging as well in joint efforts in the $21^{\text {st }}$ century.

\section{Conclusion}

I will try one last time here to render comprehensible this notion of the internal exile of Québecers by recalling another historical event, General Charles de Gaulle's famous cry, on the balcony of Montréal's City Hall in July 1967, of "Vive le Québec libre!" It is appropriate to be a little nostalgic when reflecting on the events of 1967. It was the centenary of the so-called Canadian Confederation and the World's Fair in Montréal, a time when people from here and abroad were invited to live with hope and idealism at the height of Saint-Exupery's lyricism in Terre des Hommes. It seems to me that de Gaulle's speech had such an impact because it responded to three deep aspirations of Québec society: 
it solemnly affirmed Québec's right to be different within Canada and North America, it gave a strong taste of political freedom which can take several forms in the modern world, and, finally, it answered a universal desire for recognition. In 1967, de Gaulle gave a planetary dimension to the Québec question. When we attempt to understand the deep significance of the Charter of Rights and Freedoms for Canada, we realize that it has reinforced similar aspirations for the majoritarian nationalism of those Canadians living outside Québec and a substantial minority within Québec.

By proposing an intelligent balance between individual rights, collective rights, and rights for people within minority communities, and doing so in an original way when compared to the American Bill of Rights, the Charter represented a strong affirmation of Canadian difference within Western liberal democracies. Second, the Charter helped to complete, on the axis of political freedom, the absolute independence of the Canadian nation-state. Finally, both the Charter and its influence on the world have fuelled Canadians' desire for recognition, in making their country the vanguard of a different kind of civilization for the $21^{\text {st }}$ century. This is what we can conclude by reading the best thinkers of Canada's idealist school, such as Charles Taylor, James Tully, Will Kymlicka, John Ralston Saul, and Michael Ignatieff. The Chief Justice of the Supreme Court of Canada, Beverley McLachlin, was writing in this tradition in a speech that she delivered on April 17, 2002, on the occasion of the $20^{\text {th }}$ anniversary of the Charter's proclamation:

We have a Charter that reflects our most fundamental values, that tells us who and what we are as a people. We have a Charter that the world admires. Most important of all, we have a Charter that Canadians in the last two decades have come to embrace as their own. La Charte: c'est à nous. La Charte: c'est nous (The Charter belongs to us; the Charter is us). ${ }^{6}$

We can therefore understand that the Charter is a source of great pride in Canada and that many people have the urge to say, like the Chief Justice in 2002, that the Charter belongs to us and that the Charter is us. Except that, seen from Québec, this Charter was adopted in an anti-democratic way without our consent, in defiance of the opposition of our government and the National Assembly. Commenting on the patriation of the constitution without Québec's consent, Claude Ryan stated:

We must conclude with great certainty that each time the essential prerogatives of the National Assembly are attacked, the people of Québec are themselves attacked. To be indifferent to such an attack on the powers of the

6 This quote is taken from English version of the original speech: http://www.scc-csc. gc.ca/court-cour/judges-juges/spe-dis/index-eng.aspx. 
National Assembly is to be indifferent to, or to make light of, the aspirations and the fundamental reality of the people of Québec themselves. ${ }^{7}$

Québec's legislative autonomy in language matters was reduced, the federal principle in our institutions was weakened, and, in our political culture, Québec's right to difference was not included in the Charter. More specifically, the Canada of 1982 and the Charter do not explicitly recognize either Québec's difference or the fact that this difference should lead to political and legal consequences. Canadian idealism, which sees our political system and especially the Charter as a standard-bearer for humanity as a whole, seems condemned to remain deeply inauthentic as long as we have not found a fair and reasonable way to recognize Québec's difference, legally and symbolically (Dufour 2000, 114). Without being able to deal here with all aspects of this issue, it seems clear to me that Québecers have chosen to live their quest for identity and freedom from within Canada. Québec is in Canada to stay, even if it recognizes itself imperfectly in Canadian institutions.

Charles Taylor, a great mind from McGill University and Québec, stressed once, reflecting on Québec's nationalism, that we need to be ruthless towards our essentialist myths. Canada's majoritarian nationalism has locked itself into a similar essentialist myth when it imagines that we can hide the deep political alienation within Canada, the internal exile of Québecers. ${ }^{8}$ Another great mind of Western humanism, Paul Ricoeur, wrote that the historical memory of any people must be fair and happy. The internal exile of Québecers, therefore, is a fundamental obstacle to the development of a fair and happy historical memory in Canada after more than thirty years of the Canadian Charter of Rights and Freedoms.

Speech at the Assemblée nationale du Québec on September 30, 1981. Quoted in Bélander et al. (1994, 39).

8 For two intelligent and exemplary illustrations of this majoritarian Canadian nationalism, see Crowley (2009) and Bricker and Ibbitson (2013). 


\section{CHAPTER 2 \\ The Contemporary Meaning and Utility of Federalism}

A hundred years ago, Europe was about to experience the upheavals of World War I. Naturally, in our world today, with galloping globalization, complex governance, technological sophistication, and a kaleidoscope of multiple, interwoven identities, we cannot anticipate all that the $21^{\text {st }}$ century has in store for us. In this chapter, I wish to reflect on the contemporary utility of federalism by pointing out the principal challenges and problems that this form of political organization and governance culture will have to deal with in the foreseeable future. I also draw greater attention to the problems and innovations of the last decade. First, however, I make a few remarks on the spirit and philosophical framework in which I conduct this reflection.

Fernand Dumont, a major Québec intellectual, wrote that history gradually breaks the institutions that it creates, but that this does not eliminate the need to use our power responsibly (Dumont 1987, 231). In this vein, I think that we should follow Isaiah Berlin, according to whom the worst of all evils is doctrinal dogmatism, even if it is morally well intentioned. Berlin reminds us that"we must engage in what are called trade-offs rules, values, principles must yield to each other in varying degrees in different situations" (Berlin 1990, 18). This is, according to him, the first condition for an acceptable society. Federalism is thus not an end in itself. It has to be viewed as a means of establishing and cultivating a suitable, truly human society. This means a society that gives a major role to the basic foundations of individual conscience (self-esteem, effort, caring for others); the necessary institutional balances required to limit state power; the objectives of equal opportunity and distributive justice; legal and symbolic equity between the majority and minorities; a culture of judgment and accountability for individuals and the political class; achieving, in accordance with Paul Ricoeur's fine formulation, a just and happy memory of historical events; and, promoting a public sphere encouraging mutual criticism and open debate on possible futures for the societies in which we happen to live. The spirit encompassing all of this is a modest ethics of consideration and responsibility. I acknowledge that this spirit belongs to the heritage of liberal democracies, and it is in this framework that I situate my discussion of federalism. 


\section{The Meaning and Utility of Federalism}

Federalism is a form of political governance in modern societies. From the political angle, it makes it possible to combine, on the part of federal partners, aspirations for autonomy, separation, and freedom with desires for unity, solidarity, and interdependence. Legally, a federal state is anchored in the principle of sharing sovereignty and legislative competencies between two autonomous orders of government, neither of which is subordinate to the other. Socially, federal society can be said to flow from recognizing the pluralism and heterogeneity of society. Over the last ten years, particularly under the personal leadership of Ronald Watts and the institutional leadership of the Forum of Federations, a great deal of research has been done on the internal diversity of federal governance. In-depth comparative studies have also been produced on most dimensions - the constitutional framework, legislative competencies, tax rules, pluralism, and identity - thus encompassing all institutional characteristics and political culture aspects that need to be established and respected for the spirit of federalism to prosper (Watts 2007). However, beyond the institutions and cultural dimensions dear to political scientists, federalism demands a certain ethical stance, consistent with the lines by Berlin quoted in this chapter's introduction. Denis de Rougemont provides, in his open letter to Europeans, a good description of such an ethical stance:

I propose to call the federalist problem a situation in which two contradictory, yet equally valid and vital, human realities face each other in such a way that the solution can be sought neither in reducing one to the other nor in subordinating one to the other, but only in a way that encompasses, satisfies and transcends the requirements of both (de Rougemont 1976, 205).

Over a decade ago, Québec political scientist Alain-G. Gagnon (1993) and Catalan political philosopher Ferran Requejo (1998) both reflected on the different faces of the usefulness of federalism. Essentially, their comprehensive views have not aged. In theory, as they note, federalism is remarkably well adapted to the requirements of complex governance in our globalized world. It makes it possible to combine the advantages of unity with those of preserving diversity, the assets of autonomy with solidarity and interdependence, and the benefits of both centralization and decentralization. It is a flexible, adaptable form of governance built on a series of precarious equilibriums that are in tension and force governments as well as individuals to constantly revise their judgments while demonstrating a sense of compromise and tolerance (Levy 2007; Weinstock 2005). In theory, once again, federalism embodies the idea of a public ethics of responsibility and consideration that I have been advocating here. By dividing sovereignty and increasing the number of decision-making centres, federalism protects individual freedom and creativity against the 
tyranny of the majority or majorities. While it protects the autonomy and separation of local communities, it also encourages and creates solidarity habits, beginning with the very real social fabric of the base communities. Such solidarity habits are immensely useful for appropriate management of the common good, which is becoming increasingly more globalized (Burelle 2005, 41). By allowing the spheres of deliberation to proliferate and multiply, once again on the very real basis of local communities, federalism can contribute to quite an edifying civic education, consolidate democratic values and culture, and fight against the trends towards political fragmentation, cynicism, and anomie that Charles Taylor (1992) has associated with one of the great malaises of modernity.

In many states with plural nations, federalism can provide governance tools for managing, reducing, and reformulating, as required, all of the tensions associated with the diversity of belonging. Indeed, the principal works by Gagnon and Requejo over the last decade have focussed on this dimension (Gagnon and Iacovino 2007; Requejo 2005a). In the domain of public policy, federalism strongly encourages innovation and inventiveness by increasing the number of social-political testing grounds and by promoting emulation among the various governments operating, with perfect legitimacy, in their respective jurisdictions (Gagnon 1993, 34; Pratte 2007, 275). Certainly, there will be emulation among different federated states, which rival one another with respect to imagination in many areas, but there will also be emulation between a federation's central government and its federated partners. Here, the basic idea is associated with that of Machiavelli in his Discorsi, where he described the conflicts, tensions and upheavals among the various "humours" (umori) as having an overall positive effect on the health and freedom of the whole political community. In a federal regime, the various orders of government can each, in their own manner and in their own separate fields given that they are divided by jurisdictions, take actions with direct impact on individuals. Federalism does more than admit that this will cause tension; it even goes so far as to encourage this competitive dimension.

In theoretical discussions about federalism, as in most areas of political philosophy, we can feel the simultaneous presence of both an idealistic disposition and a more realistic attitude (Noël 2006). The above quote from Denis de Rougemont is a good illustration of this. On one hand, in a realistic manner, de Rougemont acknowledges that our societies contain contradictory values and phenomena that cannot be reduced to one another. However, he also writes that the solution is to be found in the theoretical constructions and institutions that encompass, satisfy, and transcend the requirements of both extremes. This resembles the idealist telos of the fusing of horizons that we find in hermeneutic philosophy, 
from Ricoeur to Gadamer and Taylor. However, if there is one thing we have learned from the $20^{\text {th }}$ century, it is indeed that conflicts and tensions go hand in hand with political life, especially in liberal democratic regimes. We thus have to abandon dreams of the transcendence of a certain form of federalism tempted by messianism and eschatology. Instead, we must content ourselves with more modest, attainable hopes of appropriate federal regimes and suitable societies, in accordance with Berlin's words. It is in this spirit that I approach the question of the challenges and problems now facing federalism.

\section{Federalism's Challenges and Problems}

In a recent essay on the contemporary relevance of the notion of federalism, Watts describes three recent innovations in the development of systems and regimes inspired by federalism (Watts 2007, 15-16). First, he points out the tendency towards the emergence and consolidation of hybrid systems combining elements of federal doctrine, such as shared sovereignty, and the confederal idea, associated with limited delegation of responsibilities to a central level by partners that retain their full sovereignty. According to Watts, the European Union exhibits such a hybrid configuration. I will leave it to others to discuss the challenges that it will face in the next decade. Watts adds that more and more countries with federal constitutions and federated bodies are engaging in an institutional interplay and dialogue with supranational entities. This is the whole question of multi-level governance, which involves simultaneously challenging democratic transparency, efficiency in conducting intergovernmental relations, and reciprocal accountability with respect to decision-making. Finally, Watts casts a favourable eye on the trend towards accepting a certain degree of asymmetry in the participation of federated entities with respect to the conduct of international relations and interactions with supranational organizations in general. From this perspective, I could give the example of Canada, which agreed in a 2006 accord with Québec to the latter's - entirely asymmetrical - participation in a major international organization, namely UNESCO. ${ }^{1}$ I will begin with this point to examine one of the primary contemporary challenges, namely the management of multiple identities.

I insist on this issue because it is crucial both in Catalonia and in Québec, two national societies that have occupied a great place in my thinking over the last decade. However, I must recognize that on the global scale, since the September 11, 2001 attacks, its relative importance in discussions has diminished somewhat, and has yielded to security

See Chapter 5 on What Canadian Federalism Means in Québec. 
concerns. In a famous text on identity, diversity, and recognition policies, the philosopher James Tully (2003) pointed out that today's kaleidoscope of identities is composed of multiple identities that are themselves multiple, open to outside influences, constantly negotiated, and thus involved in continuous processes of transformation. He believes that this does not necessarily lead to disorder, anarchy, and complete relativism because it has been shown that people can, over several generations, be persuaded through democratic dialogue of the worth of maintaining and fulfilling one of their main sources of identity, for example, through their linguistic, cultural and national roots. In this regard, he mentions the examples of Scotland and Catalonia. When it comes to identity struggles and appropriate dimensions of identity constellations, Tully opposes fixism, monism, and the quest for authenticity. He promotes identities that will be "supported rather than imposed, reasonable rather than unreasonable, enabling rather than handicapping, endowed with liberating rather than oppressive effects" (Tully 2003, 519). However, normative theory insufficiently explains recent developments regarding the management practices of federal regimes regarding plural identities.

The political and intellectual communities of multinational states produce their own interpretive traditions of the federal regime in which they live (Weinstock 2005). On this point, as a general rule, we see major differences at work between the interpretive traditions of majority national communities and those of minority national communities. Regarding the aspects of federalism that have to be balanced, majorities focus on unity and solidarity/interdependence supported by arguments based on efficiency, performance, uniform justice, and social integration. In contrast, minorities focus on autonomy, asymmetry, and their own symbolic and legal empowerment. One of the major challenges of federalism today is thus to create, on the level of political culture and civic education, counterweights to the dominant tendencies of both majorities and minorities. The latter have to be encouraged to target autonomy less exclusively and look more towards solidarity/interdependence. Such efforts, however, will be in vain if we do not, at the same time, take actions that encourage the majority to see worth in promoting the autonomy and political freedom of national minorities. Theoretical debates about multinational federalism may have reached their limits. We now need to insist more on federal civic education and institutional counterweights. In their work on theories of federalism, Dimitrios Karmis and Wayne Norman mention this dimension when they write that, in multinational states, it is important to promote "a healthy sense of identity and loyalty of all citizens to both their subunit and the federal state" (Karmis and Norman 2005, 17). A new generation of serious work on the history of ideas is required to better understand the complexity and wealth of majority and minority national 
communities' interpretive traditions with respect to federalism. It is vital to identify, within each community, the foundations most likely to be of use in renewing their mutual dialogue given today's dilemmas.

The classical definition of federalism is based on the idea of a state in which there are at least two orders of government. However, in light of the practices within today's federal societies, we can say that a federal state is instead one in which there are only two orders of government that are sovereign with respect to their constitutional legislative jurisdictions. This relegates regions and cities to a subordinate legal and political status. Over the last decade, against a background of globalization's accelerating processes and fluxes - think, for example, of immigration issues in cities such as Barcelona and Montréal - federal regimes have been confronted with global cities that want to become front line players in state governance and intergovernmental relations, in particular with respect to issues concerning poverty, security, and intercultural integration. Global cities certainly want more economic resources and abilities to take action with respect to their residents, but in the end their primary desire is no longer to be left on the sidelines when the two main orders of government discuss their power and future. They want to be full participants in the complex governance of the globalized world. They add another dimension to the architecture of multilayered governance mentioned by Watts.

The United States of America has played a very important, and probably hegemonic, role in the history of federalism and its interpretation. Over the last decade, two contradictory trends have been seen in that country. First, in the wake of the September 11, 2001 attacks, the rigidity and complexity of power sharing in classical American federalism have been challenged by those who would like to see the central government as the principal, if not the only, player authorized to lead and take all action required to combat terrorism (Donohue and Kayyem 2002). As a counterweight to this, other experts have suggested that the division of powers in the United States should be adjusted so that the central government can concentrate on certain essential issues while micro-managing less in areas such as health care, education, municipal affairs, and social services (Nivola 2007). As we can see, in one of the first lands having constitutionally enshrined the principles of federalism, the debate remains lively and the fundamental tension between the centripetal and centrifugal forces goes on, even as change continues. Precarious, unstable equilibrium remains the fundamental characteristic of federalism in the $21^{\text {st }}$ century.

\section{Conclusion}

In general, writing on federalism tends to be dominated by institutional perspectives. In the last fifteen years, particularly with respect 
to multinational federalism, political thought has been very dynamic. I am gambling that, at the dawn of the next decade, the utility of federalism will have to be defended beyond the circles of leaders, experts, and intellectuals who form the primary audience of organizations such as the Forum of Federations. I think that, from now on, the greatest effort will have to be put into a true pedagogy of federalism targeting the people. Given the sophistication of technology and urgent political and bureaucratic concerns, namely, security and the environment, the objectives of efficiency and performance sometimes draw attention away from the complex dialogues that come with the practice of federalism. The citizen in front of her or his computer tends not to think too much about the subtleties of the federal division of powers between governments. Some education about this is required. As I have tried to show in this chapter, the political culture of federalism has to be promoted systematically in federal civic education programs. In the end, this is perhaps the greatest challenge facing federalism today. 



\title{
CHAPTER 3 \\ Making Sense of Canada as a Federal System The Relevance of Historical Legacies
}

\author{
In honour of the late Richard SIMEON (1943-2013)
}

In philosophy, law, history, sociology, and political science, mostly in English and French, an incredibly vast bibliography exists on the Canadian federal system, the Canadian state, and the historical and political identities of Canada and Québec. I will start this chapter with four general approaches (sometimes visions, sometimes past historical contributions) about the nature of the Canadian state and of the Canadian political identity. I supplement this introductory sketch with a brief enumeration and discussion of the most important years or periods that are essential to understanding the foundation or re-foundation of Canada. This preliminary sketch leads to, and helps make sense of, the four interrelated historical legacies that I wish to discuss in this chapter. ${ }^{1}$

In the prolific conversation about the nature of Canada some voices have more authority than others. Of course, this does not mean that these voices are necessarily right. In 1998, in the famous Reference re Secession of Québec decision, the Supreme Court of Canada identified four interrelated principles, anchoring, according to its interpretation, the political and constitutional identities of the country: federalism, democracy, constitutionalism and the rule of law, and respect for the rights of minorities (Réjean Pelletier 2009, 69). For the purposes of this reflection, I will only add that the insistence of the Supreme Court on the centrality of federalism makes necessary the examination of this principle and of its double logic of autonomy-interdependence as one of the major historical legacies at work in Canada. A few years later Will Kymlicka (2003), one of the preeminent Canadian philosophers and intellectuals

\footnotetext{
$1 \quad$ A first draft of this chapter was presented at a workshop dealing with historical legacies in federal regimes, organized at Howfield Manor, near Canterbury by Michael Burgess and Cesar Colino. At this workshop, presentations on Canada were made by both myself and the late Richard Simeon. In revising this chapter for my book, I wish to pay homage to Richard's exceptional qualities as a scholar and as a generous and caring human being. We shall miss him very much.
} 
of our times, wrote an article entitled "Being Canadian" for a leading British scholarly journal entitled Government and Opposition. In this article, Kymlicka discussed both external and internal sources characterizing the modern Canadian identity. Interestingly, commenting on his list of external sources, Kymlicka started by mentioning the fact that Canadian identity means being non-American, disassociating ourselves from the great southern republic that is our only neighbour. He also added that Canadians can be characterized as citizens of the world sympathetic to cosmopolitan and multilateral projections, and as members of Western civilization without the missionary zeal of the United States regarding the ideas of the liberal Enlightenment and the project of securing the triumph of democracy. He concluded by arguing that Canadians are also part of the New World, identifying themselves more with the promises of the Americas than with the heritage of Europe. Looking at Canada from within its frontiers, Kymlicka argued that Canada's political identity owes a great deal to the fact that the political system has to deal simultaneously with three layers of deep diversity: a territorially concentrated national minority in Québec, Aboriginal peoples distributed across the land, and a substantial immigrant population associated with the politics of multiculturalism. If we isolate and compare one by one the dimensions suggested by the Supreme Court and the characteristics singled out by Kymlicka, I believe readers will indeed agree that both talk about the same country. However, those are rather contemporary voices. Let me now turn to $19^{\text {th }}$ century voices, to the views of three people associated with Canada's federal founding between 1864 and 1867, to the three leaders of the Great Coalition of the government of colonial United Canada: George Brown, John A. Macdonald, and George-Étienne Cartier (Ajzenstat et al. 1999).

Brown and Macdonald did not agree on everything, as will become clearer at a later stage of this chapter, but they did agree on a couple of essential matters. They agreed on the necessity of uniting British colonies north of the United States to create an autonomous and powerful federal Dominion within the British Empire. Cartier, the French and Catholic leader of what was then called Canada East (contemporary Québec, also previously known as Lower Canada), shared these essential insights and projects of Brown and Macdonald. However, he enriched them by adding that, in the words of my colleague André Burelle, this union should be brought about without fusing the founding groups partaking in the discussions about political reconfiguration (Burelle 2005, 442). ${ }^{2}$ Cartier, at the same time, promoted the idea of a new Canadian political nationality and

\footnotetext{
At the time, and in the scholarly literature, many words can have been used to describe these groups: founding races, communities, peoples, nations, cultures, distinct societies. The key idea here remains "union without fusion."
} 
defended the kind of political autonomy, within federalism, that would enable Canada East to maintain and enhance its distinct identity. The four historical legacies I further identify and discuss in this chapter flow from the combined insights of both the older and contemporary figures mentioned here. Tables I and II , which follow here, facilitate the interpretation of these realities.

\section{Table I: Founding Dates, Moments, and Periods}

\begin{tabular}{ll}
\hline Date(s) & Significance \\
\hline $5000 \mathrm{BC}$ to & Presence of Aboriginal peoples on the territories of contemporary \\
$1500 \mathrm{AD}$ & Canada. \\
1492 and 1534 Cabot in Newfoundland and Cartier in Gaspé. Original encounters \\
between Aboriginal peoples and European explorers. \\
Founding of Québec by Champlain and permanent French-European \\
colonization seen as the founding of Canada. \\
Treaty of Paris and British Royal Proclamation, the latter seen as a \\
major constitutional document for Canada. \\
French cession and British conquest provide the legal anchors for the \\
rights of Aboriginal peoples and fiduciary relationship between them \\
and British Crown. \\
Assimilationist policy vis-à-vis new French and Catholic subjects, \\
les Canadiens, combined with the promise to give them the same \\
legal and political rights prevailing in Britain, including the right to a \\
legislative assembly. \\
Quebec Act, 1774 . Major British constitutional document for Canada, \\
enlarging the territory of the colony and establishing a policy of \\
tolerance and acceptance of diversity. \\
French civil law re-established. \\
Elimination of barriers for Catholics as a new modus vivendi with the \\
Catholic Church is established. \\
Greater toleration for French language but arbitrary and discretionary \\
political colonialism. \\
No promise of an assembly in the foreseeable future. \\
In the context of the American War of Independence, arrival of British \\
Loyalists who would, in time, become Canadians. \\
Constitution Act, 1791 partitioning the colony into Lower Canada \\
and Upper Canada and establishing a parliamentary assembly in each \\
colony, preserving substantial elements of discretionary and arbitrary \\
political colonialism at the executive level. \\
Fusion of Lower Canada and Upper Canada into the Province of \\
Canada, following the failed rebellions of 1837-1838. \\
Seen as permanent subjugation of les Canadiens. \\
Hailed as civilizational victory by some (e.g., Lord Durham) \\
Lamented by others as the beginning of la survivance or melancholy \\
nationalism in French Canada.
\end{tabular}




\begin{tabular}{|c|c|}
\hline Date(s) & Significance \\
\hline 1848 & $\begin{array}{l}\text { Advent of Responsible Government. } \\
\text { Enlightened British colonial elites (e.g., Lord Elgin) and Canadian } \\
\text { political leaders (e.g., La Fontaine and Baldwin) combine to gain } \\
\text { control of the executive branch in most colonial legislatures, selecting } \\
\text { the executive from legislative ranks.. } \\
\text { Re-establishment of the legal and political legitimacy of the French } \\
\text { language in governmental and parliamentary institutions. } \\
\text { Progressive-reformist government elected in the Province of Canada. } \\
\text { Acceptance of the idea that Canada East (formerly Lower Canada, } \\
\text { soon the Province of Québec) with its distinct cultural and social } \\
\text { identity is a permanent feature that merits continued existence. }\end{array}$ \\
\hline 1867 & $\begin{array}{l}\text { Creation of the federal Dominion of Canada with the union of three } \\
\text { colonies: the Province of Canada, New-Brunswick, and Nova Scotia. } \\
\text { The Province of Canada is once again subdivided with the creation of } \\
\text { the provinces of Ontario and Québec. } \\
\text { First combination of British parliamentary and federal forms of } \\
\text { political governance. } \\
\text { From Manitoba in } 1870 \text { to Newfoundland and Labrador in 1949, six } \\
\text { additional provinces are eventually added to the federation. }\end{array}$ \\
\hline $1897-1901$ & $\begin{array}{l}\text { As Prime Minister, Wilfrid Laurier protects, during the Colonial } \\
\text { Conferences in London, the new autonomy of the Canadian Dominion } \\
\text { from British aspirations to re-centralization of British Empire in the } \\
\text { context of greater German power. }\end{array}$ \\
\hline 1931 & $\begin{array}{l}\text { Statute of Westminster consolidates Canada's political independence } \\
\text { and autonomy from British governments and legislations. } \\
\text { Establishment of an autonomous and distinct Canadian crown. } \\
\text { Federal government gains autonomy over defence and foreign affairs. } \\
\text { Statement by British authorities that they will not legislate in Canadian } \\
\text { affairs unless asked to do so by Canadian authorities. }\end{array}$ \\
\hline 1947 & Establishment of autonomous and distinct Canadian Citizenship. \\
\hline 1949 & $\begin{array}{l}\text { Appeal procedure to the Judiciary Committee of Privy Council in } \\
\text { London abolished. Supreme Court of Canada becomes truly supreme. }\end{array}$ \\
\hline 1982 & $\begin{array}{l}\text { Constitution Act, } 1982 \text { terminates the British government and } \\
\text { Canadian Parliament's authority in matters of constitutional revision. } \\
\text { Enshrinement of the Canadian Charter of Rights and Freedoms. }\end{array}$ \\
\hline
\end{tabular}

Table II: Four Historical Legacies

\begin{tabular}{cc}
\hline Number & Legacy \\
\hline 1 & British connection, British heritage. \\
2 & Centrality of the state for the preservation and development of a Canadian \\
national project.
\end{tabular}




\section{Historical Legacies: Their Nature, Role, Interrelations, and Contemporary Significance}

In this section, I identify and discuss the four major historical legacies stemming from Table II. At this early stage, I only begin to address the issues of their interrelations and of their contemporary significance.

\section{A. British Connection, British Heritage}

At the time of Canada's federal founding, between the years 18641867, the British connection was paramount in the minds of colonial leaders. It would soon become the most fundamental, overarching characteristic of the 1867 Constitution, its institutions, and its political culture. The federal Dominion of Canada was created as a constitutional monarchy within the British Empire, operating within the Westminster system's conventions and the legal parameters of cabinet and parliamentary government. As applied in Canada, this system is as valid for provincial governments and legislatures as it is for their federal counterparts. We can immediately see that this system has a number of consequences for the functioning of federalism in Canada. As Simeon (2006) and Smiley (1980), among others, have observed, this system brings tight interconnectedness between government's legislative and executive branches, tilted towards executive dominance. Within the executive, leadership and initiative have evolved towards much greater concentration of power in the hands of the Prime Minister or Premier, once again both in central and provincial capitals. Simeon aptly summarizes the meaning of all this for understanding the dynamics of intergovernmental relations in Canadian federalism:

It is executive federalism, in which the primary contacts are between the First Ministers (Prime Minister and Premiers), ministers and senior officials of the two orders of government. It is a government-to-government relationship that has also been called 'federal-provincial diplomacy.' Legislators and legislatures play little role in the system (Simeon 2006, 2).

Much of the 1867 Constitution's originality had to do with combining the Westminster model with federalism. I shall explore this in greater detail while examining more systematically federalism as a historical legacy in its own right. At the time of Canada's founding, the British connection extended way beyond the institutions of the Westminster system. Canada claimed for itself the British idea that this system was also an ideal means for securing individual freedom, carrying with it a political culture of moderation, gradualism, and evolutionism. Canada inherited the British anti-radical attitude towards political modernity. This clearly distinguishes Canada from French and American political cultures. From 
1867 to 1982 , the long process leading to the full legal autonomization of Canada from the British state has been characterized by the spirit of this anti-radical political culture. I use the expression "Quiet Decolonization" to characterize this process. Constitutional transformations in Canada are governed by this same element of the British heritage. Whereas France, for instance, needs to demolish the previous house to erect a constitutional reform or "new home", Canada, as it did in 1982, adds a new floor or level to the existing edifice. In its capacity to act, as we shall see with the next historical legacy, the Canadian state is indeed a very important institution. However, following the British tradition, it remains a limited liberal state. The most important customs and traditions inherited from Britain - rule of law, constitutional monarchy linked with a central role for Parliament, and the system of responsible cabinet government - combined to protect Canada substantially from the perils of authoritarianism well before the enshrinement of the Canadian Charter of Rights and Freedoms in 1982.

This British heritage was also central in 1867. At that time, about $60 \%$ of Canadians claimed British descent, whereas about $31 \%$ were of French origins. In the early $21^{\text {st }}$ century, Canadians of British stock constitute about $34 \%$ of the population. Diversification through massive immigration has thus reduced, at least in demographic terms, the importance of this aspect of the British connection. Nevertheless, $60 \%$ of Canadians still recognize English as their mother tongue, and English remains the dominant language of about 78\% of Canadians (Gagnon and Simeon 2010, $110,113)$.

The next historical legacy I wish to consider is the contribution of the Canadian state towards the development of a distinct Canadian national project in the Americas. In one important aspect, this second legacy is closely associated with the British heritage. In the fifty years following the federal founding in 1867, the administrative elite of the Canadian federal or central government followed colonial precedent in maintaining extremely close links with the British imperial and state bureaucracy. When I insist on the idea of a strong state (or, to speak like the Spanish, a vertebrated state) as a major characteristic of the Canadian system, I also have in mind the contribution of a competent, dedicated bureaucracy cultivating the virtues associated with public service, but also carrying in their relations with their provincial counterparts the presumption of cultural and epistemic superiority which has long been a trademark of the British imperial bureaucracy. I also wish to claim that this dimension bears consequences for the practice of intergovernmental relations at the heart of Canadian federalism - the third historical legacy to be examined. 


\section{B. The Centrality of the State for the Preservation and Development of a Canadian National Project}

The key argument in this section is that the Canadian state has always played a central role in distinguishing the country from the United States and fostering a specifically Canadian national identity. Whereas the American dream is structured around a principled individualism and a deep mistrust vis-à-vis the state, in Canada the state has mostly been perceived as a benevolent protector of the community. In the United States, the founding documents sacralize individual projects and the protection of life, property, liberty, and the quest for happiness. In Canada, as can be found in the preamble of section 91 of the 1867 Constitution, whose objective was to broaden the powers of the central government, the state was deemed responsible for the preservation of peace, order, and good government. In order to construct and develop an autonomous and distinct country north of the United States, the idea of an East-West statist voluntarism was essential. This grand ambition was implemented and renewed in a series of national policies from the $19^{\text {th }}$ century until now: Canadian tariff policy and the building of railways, massive immigration in the new Western provinces, the establishment of the welfare state and the consolidation of national institutions from the late 1930 s to the late 1950 s (e.g., federal control over transport and telecommunications, new economic and social programs, Canadian citizenship, full judiciary autonomy, establishment of national cultural institutions, and the renewal of national symbols in the 1960s such as the anthem and flag), and full constitutional independence in 1982 combined with the enshrinement of the Canadian Charter of Rights and Freedoms.

It is my contention that the centrality of the state, as a major legacy, has maintained its importance since the federal founding in 1867 and throughout the $20^{\text {th }}$ century. I recognize that some experts could ask that this argument be reconsidered in the context of the libertarian and at times anti-statist philosophical orientation of Canada's current Prime Minister and Conservative leader, Stephen Harper. Since 2006, Harper has led governments that have given some indications (e.g., reducing the Department of Foreign Affairs, Trade and Development's budget for cultural diplomacy and promotion of Canadian studies, as well as reducing Statistics Canada's ability to gather data concerning the identities and social mores of the Canadian population) that a more serious attack on the Canadian statist tradition could be in store.

I would now like to examine a key dimension of the Canadian statist tradition: the fiduciary role of the federal or central government in safeguarding the identities and rights of minority communities. Many aspects 
of the key $19^{\text {th }}$ century constitutional document (i.e., the British North America Act, 1867) illustrate this role. Although education belonged to the sphere of provincial jurisdiction, section 93 of the Constitution offered substantial protections to minority Catholic and Protestant communities in the provinces. This included the authority of the federal government to pass remedial laws. The English-speaking minorities in Québec found additional protections in the role of the English language in the province's legislative and judiciary institutions as well as in the crafting of senatorial districts. Generally speaking, it can be argued that the reservation and disallowance powers enabling the central government to act against provincial jurisdictions were at the time seen as additional protections for minorities. In the $19^{\text {th }}$ century, French minorities outside Québec did not benefit from the same provisions and protections established for the English-speaking minority in Québec. This is relevant for one pole of the last historical legacy I shall examine in this chapter, English-French duality. However, it can also be argued that the adoption of federalism (my third legacy) constituted in itself a strong protection for the majority French and Catholic population of Québec, representing about a third of the overall Canadian population at the time. Québec, like the other provinces, obtained substantial jurisdictional autonomy over key aspects of its distinct societal autonomy (e.g., over education, family, municipal and cultural affairs, and property and civil rights). At least indirectly, through the workings of section 94 of the Constitution, Québec was protected from standardizing interventions by the federal government in the field of property and civil rights. In sum, the Canadian state, in the $19^{\text {th }}$ century, mattered in legal and economic affairs at the beginning of the quest towards a strong Canadian national project increasingly autonomous within the British Empire It also mattered because it acted as a legal protector for minority communities. Standing at the end of a long process of consolidating a Canadian national identity owing much to the interventions of the federal government, the constitutional reform of 1982 and the Canadian Charter of Rights and Freedoms have continued this tradition.

The Charter enshrined various rights for at least three distinct (though interrelated) minority communities: linguistic minorities (Anglophones in Québec and Francophones elsewhere), securing mostly symmetrical protections through sections 16-23 of the Charter; Aboriginal peoples (section 25 of the Charter and Parts II, section 35, and IV- Constitutional Conferences with Aboriginal peoples, abrogated after the failure of these conferences in the 1980s); and, rights for ethnic communities through an interpretive provision requiring respect for the objective of promoting the multicultural heritage of Canadians. I believe it has now become a received idea in the scholarly community, everywhere in Canada, that this reform 
was a major act of Canadian nation-building and that the enshrinement of minority rights symmetrically distributed across Canada to relevant groups was a key part of this project (McRoberts 1997, 137). The simple fact that all these rights remain beyond the reach of the notwithstanding clause (section 33), enabling governments to limit the exercise of some rights for a limited period, reinforces this argument (Woehrling 2009, 89). This constitutional reform was achieved at a time of great, exacerbated conflicts between the Canadian and Québec national projects. Scholars of all stripes have abundantly studied this chapter of our history. Among others, Michael Keating (2001) and Montserrat Guibernau (2007) have looked at this from the perspective of a conflict between nation-building projects in political sociology and, although Keating possesses an important Canadian background, I believe that taken together they offer us a reasonably objective narrative. So I deem the Canadian statist tradition to be a very important historical legacy. It is at work in social, economic, and cultural affairs. I believe it is coherently related to a strategy of nation building in these matters and, with striking clarity, regarding the role of protector of minorities. I shall come back to this aspect while discussing the third and fourth historical legacies. The two following excerpts, from the writings of Will Kymlicka and Sujit Choudhry, help me to make the transition to the third legacy:

English-speaking Canadians have a deep desire to act as a nation, which they can do only through the federal government; they also have come to define their national identity in terms of certain values, standards, and entitlements that can be upheld from sea to sea through federal intervention in areas of provincial jurisdiction. In short, the only way for English-speaking Canadians to express their national identity is to undermine the provincial autonomy that has made it possible for Quebecers to express their national identity. The problem in Québec-Canada relations, therefore, is not simply that Quebecers have developed a strong sense of political identity that is straining the bounds of federalism. It is also that Canadians outside Québec have developed a strong sense of Pan-Canadian identity that strains the bounds of federalism (Kymlicka, 1998: 166).

The impact on federalism of Canada's increasing ethnic diversity and the concentration of that diversity in Canada's urban centres is a question that has largely remained unexplored. My sense is that federalism is in for a bit of a shock, because many recent immigrants do not identify with Canada's self-description as a federal political community. They have not taken to federalism in the same way that they have embraced other aspects of our constitutional identity, such as rights and the rule of law. The difficulty here is that federalism offers up a conception of the Canadian political community with which immigrants find it difficult to identify (Choudhry in Studin 2006, 122-123). 


\section{Federalism: Bipolar Equilibrium, Tensions, and Interpretive Prisms}

Federalism is about balancing and the scholarly literature has offered many suggestions about what needs to be balanced: unity and diversity, selfrule and shared rule, autonomy and solidarity/interdependence, coming together and coming apart, association and dissociation, integration into a national community and empowerment of national minorities, centralization and decentralization. My first remark will be about the nature of the federal founding in Canada, starting with the perspective of the key participants from United Canada. Macdonald, who would become Canada's first Prime Minister, was in favour of a strong central government, his first preference being a legislative union between the colonies. However, he reconciled himself with the idea of a federal design, acknowledging, in his own words, that his compatriots from Lower Canada (contemporary Québec) "would not consent to the absorption of their nationality" (Ajzenstat et al. 1999, 279). For Macdonald, the federation should be as centralized as possible, considering the compromises that had to be made. George Brown and Maritime leaders also pushed for the federal idea, defending selfgovernment for colonies and provinces and supporting sufficient decentralization for the protection of local identities. Like Macdonald, Brown tried to balance in his own way the promotion of autonomous local identities and the requirements of unity to create a strong economic power north of the United States. Cartier provided the social glue between most of the participants at the federal founding, including Macdonald and Brown. $\mathrm{He}$ advocated for Québec's political renaissance, securing a strong sphere of self-government and a substantial array of competences linked to the preservation of Québec's local identity. However, he also defended the idea of a strong government at the centre, fostering in time its own political nationality. It must not be forgotten that these arrangements were arrived at within the overall structure of the British Empire. Through the emergence of the Dominion of Canada, British colonies, by coming together, became collectively more autonomous than before. However, in a number of key matters, they remained subordinate to the British government in London and to the Westminster Parliament (e.g., judicial hierarchy, legal validity, defence and foreign affairs, constitutional evolution, and overall coordination). Thus, we need an additional bipolarity to make sense of the federal founding in Canada: autonomy and subordination. This dimension characterized the relations between the Dominion of Canada and the British Empire; it also characterized the relations between this Dominion and the newly crafted provinces. This triple hierarchy was not a static affair. It did change over time, as I have already noted with the relations between Canada and the Empire passing through a long process 
of "Quiet Decolonization." It has changed as well with regards to the relations between the Canadian central government and the provinces. This complex reality is well summarized by David Cameron:

Canada was founded in 1867 as a centralized federation, with the key powers of the day vested in Ottawa, and a strong, paternalistic oversight role assigned to Ottawa vis-à-vis the provinces. Despite its origins, however, Canada has become highly decentralized. This has occurred due to a number of factors. First, judicial interpretation of the division of powers broadly favored provincial governments over the federal government. Second, the country's central institutions have been unable to represent adequately Canada's regional diversity, and there has consequently been popular support for the assertion of provincial power, especially in the stronger provinces. Third, provincial areas of responsibility, such as health, welfare and education, which were of little governmental consequence in the $19^{\text {th }}$ century, mushroomed in the $20^{\text {th }}$ century, thus greatly enhancing the role of the provinces. Finally, post-World War II nationalism in Québec has helped to force a process of decentralization from which other provinces have benefited. The result is that Canada has powerful and sophisticated governments both in Ottawa and in the provinces, engaged in competitive processes of community building, and social and economic developments at both levels (Cameron 2002, 108).

Cameron's analysis was prepared for the Handbook of Federal Countries issued in 2002 by the Forum of Federations. His views are nicely supplemented by those of the late Richard Simeon, in my judgment the preeminent scholar of Canadian federalism, in a paper entitled "Federalism and Decentralization" and also available on the Forum of Federations website. Like Cameron, Simeon considers that Canada ranks among the most decentralized federations in the world. Simeon justifies this view succinctly and coherently as follows:

Provincial governments have high 'political capacity' in the sense of a strong presence in the identities and loyalties of citizens; high jurisdictional capacity in the sense of their assigned responsibilities; high fiscal capacity in the sense of their ability to raise and spend public revenues; and high bureaucratic capacity, in the sense of their ability to design and deliver public services. Canada combines a high degree of autonomy for its constituent governments with a high degree of interdependence among them, with the resulting need for intergovernmental cooperation and coordination if the needs of the citizens are to be met effectively. It is an example of 'divided federalism', rather than 'shared' or 'integrated' federalism. The design creates two separate orders of government, each free to act in its own areas of jurisdiction [...] It combines high levels of cooperation in specific areas of public policy with considerable competition among governments for political strength and public support. It combines an emphasis on nation-wide standards in critical public services with wide variation among provinces as each seeks to meet its own needs in its own way (Simeon 2006, 1-2). 
This sub-section, discussing federalism as a historical legacy in its own right, suggests that federalism is characterized by the search for equilibrium between poles, by the persistence of tensions, and by the plurality of interpretive prisms. Anglophone and Francophone experts, both in Québec and elsewhere in Canada, have through the passage of time and over generations provided different interpretations about the nature and meaning of Canadian federalism. Generally speaking, the previous excerpts from the works of Cameron and Simeon portray Canada as a very decentralized federation, with autonomous and powerful central and provincial governments engaged in a competition of equals with shifting equilibriums over time. Generally speaking, once again, scholarship from Québec has tended to disagree with this evaluation (Kelly and Laforest 2004). ${ }^{3}$ Cameron seems to suggest that Ottawa's paternalistic oversight role vis-à-vis the provinces has disappeared. Many in Québec would argue that it has not. It is true that some of the quasi-unitary features present, according to Smiley, at the heart of the $19^{\text {th }}$ century constitution have fallen into disuse without ever being abrogated (e.g., powers of reservation and disallowance of provincial legislations). However, the emergence of a Canadian welfare state after World War II, and persistent rhetoric up to this day in Canadian politics advocating a leading role for the central government in reinforcing a Canadian economic and social union (see Kymlicka's quote above), would have been impossible without a kind of constitutional preference or supremacy given to the federal government initially in 1867 through these quasi-unitary features. Thus, the preamble of section 91 of the 1867 Constitution and some of its provisions (e.g., the peace, order, and good government interpretive clause) are, despite being contested in Québec, the legal basis of the so-called federal government's spending power, which is absolutely essential for the existence of the Canadian welfare state. Thirty years ago, Smiley had this to say about this spending power:

This power provides a way in which the federal authorities can, as they wish, insert themselves in almost any matter within provincial jurisdiction where significantly large expenditures are involved [...] The federal spending power and p.o.g.g. [peace, order and good government in the preamble of Section 91] offer the federal authorities considerable opportunities to extend their activities beyond the enumerated headings of Sections 91 and 95 (Smiley 1980, 24-25).

Smiley also believed that Canada's judicial system, vesting in the federal government the power to nominate and elevate judges to the three top courts in all provinces including the Supreme Court, was essentially

See Chapter 5 on What Canadian Federalism Means in Québec. 
unified. If this becomes the dominant criterion, Canada is among the most centralized federations, not among the most decentralized. This dimension became much more important with the patriation of the Constitution in 1982 and with the enshrinement of a Canadian Charter of Rights and Freedoms. I have already mentioned this issue while discussing my second historical legacy in this chapter, the centrality of the state for the preservation and development of a distinctive Canadian national project. Federalism is not absent from the content and legal environment of the Charter. It plays an important role in the amending formula and in the workings of the notwithstanding clause. However, it is absent from the document's crucial first disposition, which recognizes the existence of reasonable limits to rights in a free and democratic society, thus presenting Canada as a unitary or unified society rather than as a federal political community. Interpreted by a centralized judiciary branch, the Charter is an agent of centralized nation-building in three ways: at the symbolic level, it offers rights and a discourse of shared values to Canadians from coast to coast; at the level of public policy, it promotes homogenizing national standards including in the key jurisdictional field of language legislation; and, with regards to identifying the most legitimate level or unit for political deliberation, it moves issues from regional or provincial communities to the pan-Canadian national community (Woehrling 2009, 124-125; Russell 1993, 21-22).

In the fuller passages from which I have taken the quotes above, Cameron and Simeon desire smooth intergovernmental collaboration between the central and provincial authorities in search of equilibrium between real autonomy and complex interdependence. In analyzing, with Martin Papillon, the Canadian conference of leaders of federal and provincial governments, which is the institution at the apex of intergovernmental relations in Canada, Simeon concluded that it is possibly the weakest link in our institutional network. It is very poorly equipped to provide smooth, efficient, and rational coordination. Consider the following elements highlighted by Simeon and Papillon. The conference works in an ad hoc way, without consensual rules and procedures between partners, with below average (by Canadian standards) bureaucratic preparation, without clear legal or political relationships to other institutions and the normal functioning of legislative and executive politics at the center and in the provinces, without much transparency, and mostly beyond parliamentary control (no committee of the House of Commons in Ottawa controls the government of the day on its conduct or management of intergovernmental relations). Let me add that these conferences take place only when the Prime Minister decides that they should take place, that the agenda is unilaterally prepared by the federal government (Ottawa consults provinces most of the time but has the last word), and that the conferences are 
chaired solely by Prime Minister (Papillon and Simeon 2004, 125-126; Laforest and Montigny 2009, 134). It would seem to me somewhat exaggerated to extend to this institution the image of a dialogue and competition between equal partners. This institution of coordination, however flawed, has been totally ignored by Harper since he became Prime Minister of Canada in 2006. All in all, is the Canadian federation quite centralized or quite decentralized? In my judgment, there can be no definitive answer to this question. The system is indeed dynamic. It depends upon the criteria being selected. And it could prove to be that Canada is simultaneously both quite decentralized and substantially centralized, with the appropriate nuances flowing from the various positions or interpretive prisms of those providing the judgment. I shall conclude my assessment of this third historical legacy with an additional note on these interpretive prisms.

Anglophone and Francophone scholars from Québec and elsewhere in Canada have interpreted our experiment with federalism from the perspectives of philosophy, constitutional law, history, and political science, often combining approaches from several of these disciplines. In each linguistic community one can find hegemonic, dominant interpretive narratives alongside more minor or subordinate ones. For instance, the idea that the Canadian federation is mostly a pact among provinces or a pact between founding peoples or nations has long been dominant in French Canada and Québec, but it has been far from absent in Anglophone interpretations throughout Canada in general and in Québec in particular (see Vipond, Romney, Taylor). By and large, English Canadian historiography has privileged centralist, nation-building narratives focusing on a combination of my first two historical legacies (i.e., British heritage and the role of the state in sustaining a Canadian nation as seen in the work of Creighton, Cook, Lower, Scott, and Bliss). Very interesting recent developments in the history of ideas include the work of Québec political scientists and historians who have attempted to identify more precisely, and to take a greater critical distance from, the dominant narratives in Québec and elsewhere in Canada. Stéphane Kelly, Alain Noël, Alain-G. Gagnon, and François Rocher are the most important figures in this critical reappraisal and I have contributed to this genre in some of my own writings. The key idea of this interpretive historiographical reappraisal seems to me to be the following: well before, but even more consistently since, the Report of the Tremblay Commission in the early 1950s, French Canadian and Québec assessments of Canadian federalism have been dominated by the twin desires to ascertain whether this system allowed for, on the one hand, the securing and enlarging of Québec's political autonomy or self-government and, on the other hand, whether it offered a meaningful recognition of Québec's distinctiveness within Canada's constitution and political institutions. If federalism is about a 
dynamic, tense, but nevertheless real equilibrium between various polarities, including unity-diversity and autonomy-solidarity/interdependence, there is not much of it in the dominant Québec interpretive tradition. Rocher has explored the nature of this phenomenon in depth and some of its consequences for contemporary politics:

For the Québec governments, the Québec-Canada dynamic is illustrated through several concepts: attachment to the principle of autonomy, respect for and expansion of provincial jurisdictions, achieving a distinct status and asymmetrical federalism [...] It is remarkable to note that this construction has taken place, both at the discursive level and concerning the QuébecCanada state relations, on the basis of the non-participation of Québec in the building of the Canadian political community. In other words, Québec's relationship with the rest of Canada is primarily utilitarian (Premier Robert Bourassa spoke of 'profitable federalism') [...] From the point of view of political institutions and the normative project of federalism, the dominant approach is problematic in many ways. First, the emphasis on notions of pluralism, autonomy and non-subordination is clearly disproportionate to the scant attention paid to the concept of interdependence. This imbalance was present in the work of the Tremblay Commission and has seen been consistently reproduced. The desire to construct a 'complete' Québec society has privileged the expansion of the spheres of sovereignty of the Québec state and sought disassociation from the Canadian political space. In this context, the necessity of a double loyalty within the federal space proves impossible to articulate (Rocher 2009, 107, 109).

I began this chapter identifying four major historical legacies, examining in detail the character and contemporary significance of three of them, examining their relations to others and assessing, at least in a preliminary fashion, their overall impact on the contemporary federal polity. Much work remains to be done with regards to the distinction between the existence of historical legacies and their political uses and abuses. I shall now turn to my fourth, and last, historical legacy: Québec, EnglishFrench duality, French language and culture, and the role of state in Québec.

\section{Québec, English-French Duality, French Language and Culture, and the Role of State in Québec}

It would be wrong to argue that Québec is located at the geographical centre of Canada, but a strong case can be made that it has been, for decades at least since the federal founding, its historical heart. Would it be correct to make the same point in the current era? I believe that is a very debatable issue, which we could explore at greater length. Notwithstanding our answer to this question, the fact of the matter is that the very existence of a predominantly Francophone province provides Canada with a substantial element of distinction vis-à-vis the United States. As far as 
the Canadian national project is concerned, this is Québec that conforts Canada. This massively Francophone society is the primary anchor for the considerable scope of English-French duality that many have seen as $\mathrm{a}$, if not the, fundamental characteristic of the Canadian national project. Unimaginable without Québec's presence and historical role, this dualistic dimension finds contemporary expression in the legal recognition of two official languages since 1969 and further constitutionally entrenched in 1982 (see sections 16-23 of the Constitution Act, 1982). Strictly speaking, this dimension is legally, politically, and symbolically much stronger than it was in the $19^{\text {th }}$ century. An analysis studying the differences, with regards to the linguistic proficiencies and communities of origin, between the members of the Canadian public service in Ottawa in the late $19^{\text {th }}$ century, in 1950 and today, would be quite striking in this regard. In sum, the Canadian central state operates in two of the most important idioms associated with Enlightenment ideas and the ambitions of modernity, English and French. Just prior to the federal founding, in 1866, Québec proceeded with the codification of its civil law, adding another dimension to the edifice of duality by providing Canada with a second major system of law alongside British common law. In large part due to the distinctiveness of Québec, Canada possesses two global and substantially complete societal networks, two major frameworks for the welcoming of immigrants (multiculturalism and interculturalism), two networks of often interrelated civil society associations, two sophisticated technological and communicational networks, two scholarly communities, two popular cultures, and two literatures. In sum, Québec society and English-French duality have been, and still are, substantial assets for the promotion of a Canadian national project north of the United States.

In Québec and elsewhere, many are worried about the capacity of Québec, and of Canadian Francophonie in general, to maintain, deep into the $21^{\text {st }}$ century, its importance in Canada and in Canadian debates. Consider for instance the contemporary demographical reality. Today, the population of Québec, roughly 8 million people, represents about $23 \%$ of the overall Canadian population of 34 million. The following numbers, taken by my colleague Réjean Pelletier from the 2006 data compiled by Statistics Canada, feed the pessimism of those who lament the irreversible decline of Québec and French-speaking Canada. In 1941, French was the mother tongue of $29.2 \%$ of Canadians. In 2006, this figure had dropped to $22.1 \%$. In 1971 , French was the main language of daily use for $25.7 \%$ of Canadians. In 2006, this figure had dropped to $21.4 \%$. In 1931, the population of Québec represented $27.7 \%$ of the overall Canadian population. In 2006, this figure had dropped to 23.9\% (Pelletier 2008, 63-64, 69). Obviously, a half-empty glass can also be seen as half-full. From 1960 to 2000, while English was making considerable progress towards 
becoming the lingua franca of the modern world, with the immense help of technological and communicational revolutions, the French language consolidated its position as the predominant language in Québec. Over these forty years, there has been a slight decline in the proportion of people claiming French Canadian origins in the population of Québec (from $81 \%$ to $78 \%$ ). However, whereas about $83 \%$ of Québecers claimed French as a primary language of use in the early 1960 s, this figured has climbed to about $86 \%$. And whereas approximately $86 \%$ of Québecers in the early 1960 s could use French in their daily lives even if they were not necessarily speaking it at home, this figure has also climbed to about $94 \%$. To repeat the point, in the context of North America, and considering the steady progress of English in the world, these figures are nothing if not remarkable.

Looked at from the perspective of the Canadian national project, Québec can be reassuring, though it can also appear quite worrisome. In the past forty years, Québec and its own nation-building project have been at the vanguard of a group of non-sovereign political communities which have deeply troubled the central states of complex federations, their political elites, and their majority populations (Gagnon and Tully 2001; Keating 2001; Gagnon 2007). From 1960 to 2000, the formidable pressures exercised on the Canadian state by Québec's own state-driven path towards modernization and by the sovereignty movement have been at the centre of Canadian political debates and struggles. To get at the importance of this dynamic, I provide two lists summarizing the most important results and achievements obtained by the Québec and Canadian nation-building projects (see Table III and Table IV ).

Table III: Achievements of the Québec National Project Since 1960

\begin{tabular}{l} 
Achievement \\
\hline Establishment of a Québec welfare state, substantially autonomous from but also partly \\
integrated in the Canadian welfare state. \\
Québec's health-insurance card (carte-soleil); a potent symbol in the same category as \\
Canadian citizenship and the passport. \\
Québec's Pension Plan (Caisse de dépôt). \\
Public daycare program. \\
Hydro-Québec and the nationalization of hydro power. \\
Consolidation of a Québec controlled extensive communicational network operating \\
in French. \\
Role of the state in the development of a public system of education from kindergarten \\
to universities (this system is not exclusively French-speaking). \\
Charte des droits et libertés de la personne du Québec. \\
Language laws consolidating the role of French in all aspects of social life and a \\
network of state institutions to promote their spirit and rules.
\end{tabular}




\section{Achievement}

Public policies related to citizenship, including Québec's own approach towards the integration of immigrants - interculturalism.

Cultural and scientific public policies.

Promotion of a Québec-centered network of civil society associations.

Québec's international relations policy.

The consolidation parliamentary legitimacy, a representative liberal regime which promotes in the public space a political culture of pluralistic and democratic deliberation. Navigating through the websites of the Government of Québec and of l'Assemblée Nationale du Québec provides a very good understanding of the importance of this latter dimension.

Table IV: Achievements of the Canada National Project Since 1945

\begin{tabular}{l} 
Achievement \\
\hline Establishment of a Canadian welfare state from 1940 to 1950. \\
Canadian Citizenship and Canadian passport. \\
Consolidation the Supreme Court of Canada's role as ultimate national tribunal. \\
Consolidation of a Pan-Canadian communicational network (the primary one works in \\
English, but there is one in French as well). \\
New national hymns and flags. \\
Official languages policy. \\
Pluralisation of citizenship through the framework of multiculturalism to provide more \\
equitable integration. \\
Promotion of a Canadian-centered network of civil society associations (working in \\
English but also in French). \\
Various policies to reinforce the Canadian social and economic union. \\
Cultural and scientific innovation strategy and national higher education national. \\
Canadian Charter of Rights and Freedoms. \\
Canada's foreign relations policy and its intellectual tradition of liberal \\
internationalism.
\end{tabular}

Last but not least, consolidating the legitimacy of a parliamentary, representative liberal regime publically promotes a political culture of pluralistic and democratic deliberation. Navigating through the websites of the Government of Canada and of the Canadian Parliament provides a very good understanding of the importance of this latter dimension. 


\section{Conclusion}

After looking carefully at these two lists, one can arrive at the conclusion that these two nation-building projects are almost Siamese twins. I am not sure what Macdonald, Brown, and Cartier would say about the way in which the institutions and political culture of our federal founding have been transformed over almost 150 years. I nevertheless believe they would be struck by the qualitative deepening of the EnglishFrench dualistic elements in the Canadian federal polity between 1867 and 2014. 



\title{
CHAPTER 4
}

\section{The Historical and Legal Origins of Asymmetrical Federalism in Canada's Founding Debates}

\author{
A Brief Interpretive Note
}

Asymmetrical federalism is a horrible expression, typical of the jargon of political science, belonging to the same family as, say, consociational democracy. With good reason, neither expression really sells on the streets. An informed discussion can be made easier by the use of synonyms. Asymmetrical federalism means lack of uniform treatment for the various federated units within the political community. Canada has had various experiences with such absence of uniformity since 1867. Asymmetrical federalism is also a way to convey the idea of distinct or special status for federated units, particularly for Québec. This brief interpretive note is essentially concerned with this last layer of meaning. I shall argue that Canada's constitutional founders were explicitly conscious that the resolutions adopted at the Québec Conference in 1864 and substantially reproduced in the British North America Act, 1867 (Constitution Act, 1867, in contemporary parlance) granted the newly established Province of Québec a significant form of distinct or special status. They contributed to the creation of what we, as historians and political scientists of the $21^{\text {st }}$ century, call an asymmetrical federation, though they obviously did not use the expression at the time.

Two preliminary remarks precede my main argument. First, Canadian political theorists often portray the country abroad as an asymmetrical multinational federation. ${ }^{1}$ My arguments here will support their contention, but with a caveat. They are right about one pillar of our fundamental law, the Constitution Act, 1867. However they are wrong, at least with regards to Québec, if one takes into consideration only the Constitution Act, 1982. I shall come back to this point in my conclusion. Second, my work here supports a strand of interpretive revisionism in Canadian historiography, attacking the nationalist ultra-centralist readings of Creighton and F.R. Scott. With Stéphane Kelly, I am trying to

See, for instance, Kymlicka (2001, 108-109.) 
make the work of these revisionists available in French Canada and Québec. $^{2}$

Revisionist historiography has fostered a reconsideration of the centrality of George-Étienne Cartier, George Brown and Oliver Mowat, alongside John A. Macdonald, in the business of founding Canada as a federal Dominion under the British Crown between 1864 and 1867. Led by Brown and later by Mowat, the Upper Canadian Reformists were the strongest political force in what was then called Canada West and they wanted substantial provincial autonomy for Ontario. Maritime leaders also fought for local autonomy but, as Paul Romney has shown, they did not play as crucial a role as Brown or even Mowat in the wording of the key resolutions at the Québec Conference (Romney 1999, 105). As the heir to La Fontaine, Cartier was the key player in what was then called Canada East, formerly Lower Canada and the "born-again" Province of Québec after 1867. To fit Cartier's purposes, the new constitutional arrangement had to allow him to present himself to his compatriots in Québec as a strong defender of the motto common to La Fontaine and Étienne Parent: "Notre langue, notre nationalité, nos lois" (our language, our nationality, our laws). Insofar as the political landscape of United Canada in 1864 was concerned, the new order had to be federal because such was the desire of the two key players in the East and in the West, respectively, Cartier and Brown. In many respects, Macdonald is the pre-eminent person among our Fathers of Confederation. He played the leading role in the Québec Conference, in the drafting of key resolutions, and in the process of parliamentary ratification. In addition to all this, he became our first Prime Minister and, thus, he was the first political beneficiary of Confederation. However, he entered the Great Coalition with Brown and Cartier in 1864 as the minor player and the federal idea was clearly imposed on him. His own way of recognizing this, in the parliamentary debates of 1865 , is my first step in demonstrating the existence of a Québec-based asymmetrical federalism at the time of Confederation:

But, on looking at the subject in the conference [...] we found that such a system was impracticable. In the first place, it would not meet the assent of the people of Lower Canada because they felt that in their peculiar position being in a minority, with a different language, nationality, and religion from the majority - in case of a junction with the other provinces, their institutions and their laws might be assailed, and their ancestral associations, on which they prided themselves, attacked and prejudiced; it was found that any proposition

Janet Ajzenstat et al. (2004), French edition prepared, introduced and supplemented by Stéphane Kelly and Guy Laforest. In addition to the aforementioned authors, Robert C. Vipond, Sam LaSelva and Christopher Moore belong to this revisionist school. 
which involved the absorption of the individuality of Lower Canada [...] would not be received with favour by her people (Ajzenstat et al. 1999, 279). ${ }^{3}$

Whatever else our founders wanted to accomplish, they quite clearly were not seeking a constitution that would absorb the individuality of Lower Canada. From Cartier's perspective, the chief political obligation was to secure the protection of this individuality. At the time of Confederation, Cartier was the Attorney General for Canada East. One of his most important duties in the early 1860 s was to preside over the deliberations of a commission whose task it was to codify the Frenchoriginating civil law of this section of the colony. Through the Québec Act of 1774, the British Crown had formally granted to its new subjects the continuation of their French laws concerning property and civil rights. This aspect of the colony's identity had been maintained at the worst of times, i.e., in the aftermath of the 1837-1838 rebellions. In 1840-1841, the Act of Union had expelled the French language from the life of political and public institutions, but it had not attacked the French civil law heritage. The codification exercise was completed in 1866 and, at roughly the same time, provinces were given jurisdiction over property and civil rights in the Québec Resolutions (resolution 43, subsection 15) and in the Constitution Act, 1867 (known at the time as the British North America Act, 1867, section 92, subsection 13). McGill historian Brian Young has this to say about the relationship between codification and Confederation:

Confederation and codification were bedfellows in the crucial juncture of the 1860s when the form of Canadian federalism was being negotiated. In the process by which Québec became one province among others and in which French Canadians became a minority element in a federal state in which English would be the dominant language, codification institutionalized and reconfirmed Lower Canada's separate legal culture (Young 1994, 16).

A key merit of the Confederation settlement for Cartier was the restoration of Lower Canada. Québec became a self-governing political community endowed with the institutions of responsible government. This represented real progress on the axis of political freedom. As the job of codification was being completed, Cartier could also rejoice in the provision that squarely placed property and civil rights within the realm of provincial powers and local autonomy. This provision had to be seen as a safeguard for the autonomous legal identity of all provinces. It certainly went together with the federal idea, although it did not offer Québec any distinct, asymmetrical status. In order to find a basis for a Québec-based asymmetrical federalism in 1864-1867, one would have

\footnotetext{
Thus spoke Madconald in the Parliament of United Canada on February 6, 1865.
} 
to look elsewhere. The strong, unmistakable historical and legal foundation for such a principle of asymmetry is to be found in the following passage of the Québec Resolutions (resolution 29, subsection 33, slightly reformulated in section 94 of the Constitution Act, 1867):

Rendering uniform all or any of the laws relative to property and civil rights in Upper Canada, Nova Scotia, New Brunswick, Newfoundland and Prince Edward Island, and rendering uniform the procedure of all or any of the courts in these provinces; but any statute for this purpose shall have no force or authority in any province until sanctioned by the legislature thereof (Ajzenstat et al. 1999, 468).

At the time of the Rowell-Sirois Commission in the late 1930s, F.R. Scott - legal scholar, essayist, poet, and strong voice of the emerging centralist and nationalist left - formulated what would become the hegemonic reading of this provision in English-Canadian historiography. Section 94 came to be seen as a legal avenue towards centralization, allowing the federal government to standardize the field of property and civil rights in common law provinces. In Scott's own grand interpretive scheme, this was a key element in his attacks against the decentralizing thrust of the constitutional jurisprudence coming from the Judiciary Committee of the Privy Council. We shall leave aside here the related matter of the relevance of this section for the issue of constitutional amendment. ${ }^{4}$ As Sam LaSelva has argued, Scott neglected one dimension of the provision: no standardization would ever occur without the explicit consent of the provincial legislature involved in the operation (LaSelva 1995, 56-57). For my purposes here, it is interesting to point out what Scott, despite his unimpeachable centralist credentials, had to say about the relationship of Québec with regards to this provision. On numerous occasions in his famous piece on section 94, Scott $(1977,114-122)$ reiterated that it did not apply to Québec. In the field of property and civil rights, the province of Québec could not relinquish its legislative powers. Now this has to be seen as a clear legal manifestation of asymmetrical federalism. Recent revisionist historiography, such as the work accomplished by Ajzenstat et al. (1999), unmistakably supports this dimension of Scott's interpretation. On the matter of property and civil rights, our founders thought that Québec, with its civil law tradition, could never be rendered uniform with the other provinces, not even if it gave its own consent to such standardization! The following excerpts of speeches given respectively by M.C. Cameron (Canada West) and Christopher Dunkin (Canada East) in the United Canadian Parliament in 1865 lend support to such a reading of this dimension of our constitutional arrangement:

4 On this topic, see LaSelva (1995, 56ff). See, also, Laforest (2004, 201ff). 
Such being the guarded terms of the resolution, why is it not made applicable to Lower Canada as well as to the other provinces? I can easily understand the feeling of the French people and can admire it - that they do not want to have anything forced upon them whether they will or not. But they will not allow you to contemplate even the possibility of any change taking place for the general weal, and with their own consent, in their laws [...] I do not understand (Cameron, quoted by Ajzenstat et al. 1999, 305-306).

The other provinces may have their laws made uniform, but an exception in this respect is made for Lower Canada, and as if to make it apparent that Lower Canada is never to be like the rest of the Confederation, it is carefully provided that the general parliament may make uniform the laws of the other provinces only - that is to say, provided those provinces consent to it, but by inference it cannot extend this uniformity to Lower Canada, not even if she should wish it [...] They may become uniform among themselves, but Lower Canada, even though her people were to wish it, must not be uniform with them [...] Thus, in one way and another, Lower Canada is to be placed on a separate and distinct footing from the other provinces, so that her interests and institutions may not be meddled with (Dunkin, quoted by Ajzenstat et al. 1999, 346).

There were many aspects to Confederation, and many sides to Cartier's political career. I do not wish to over-simplify either of these complex realities here. Obviously, there were many centralizing aspects in the Québec Resolutions and in the Constitution Act, 1867 - many of which Cartier approved. For instance, as the person with the broadest social connections among the Fathers of Confederation, Cartier supported the powers of reservation and disallowance as a means of offering safeguards to the English-Catholic and Protestant groups in Québec (Ajzenstat et al. 1999, 435). This notwithstanding, Cartier's central achievements were the restoration of Québec's political existence and autonomy, with legislative control over local matters and affairs related to communitarian identity such as property and civil rights. Through the well-understood meaning of section 94, at least for our Founders, at the time of Confederation and of civil law codification, Québec re-emerged as a self-governing political community with substantial legislative powers and a unique, distinct, asymmetrical constitutional identity in Canadian federalism. We should not be surprised to read that similar arguments were employed when Cartier, Taché, Belleau, and others had to defend the proposed constitution in Québec:

What Confederation did was to break up that united province, and to create a separate province of Québec and a separate province of Ontario. The pro-Confederation editorialists, speech-makers, and pamphleteers pushed that aspect of the arrangement - that Québec was going to be separated, that French Canadians were going to have a state of their own which would have 
complete control over all matters of provincial jurisdiction, and that it was a move towards greater separation. That was the selling point in Québec... It was justified to nationalist-minded French Canadians as a kind of liberation: at least on provincial issues they would be able to follow their own inclinations and not to have to seek cooperation from the English (Arthur Silver as quoted in Bothwell 1995, 38-39).

\section{Conclusion}

There was indeed a strong, coherent, and logical historical and legal basis for asymmetrical federalism in Canada's founding debates, in the Québec Resolutions as well as in the Constitution Act, 1867. It was a peculiar kind of asymmetry. It was an indirect, oblique, and tacit sort of asymmetry. It had to be read through "inference "and "induction", as those who spoke about it at the time saw it. I shall call this asymétrie à l'anglaise or "English-inspired asymmetry." It was the kind of reasoning to which a sharp legal mind, trained in English or British common law, such as Oliver Mowat, was accustomed. Less than twenty years after extremists burnt the Canadian Parliament in Montréal, there was possibly politically no other way to write in the new constitution a distinct special or asymmetrical status for the re-established Province of Québec. Inasmuch as the Constitution Act, 1867 is still part of our fundamental law, political theorists like Kymlicka are thus correct to write that Canada belongs to the family of asymmetrical multinational federations. However, our constitutional law and corresponding political culture have been substantially transformed by the addition of the Constitution Act, 1982. The main author of this reform, Pierre Elliott Trudeau, did not regard favourably the principles of asymmetrical federalism or special status for Québec. His vision of liberal democracy propounded symmetrical equality for individuals as well as for provinces. On this issue, there are differences between Trudeau's personal vision and the content of the reform's most important aspect, the Canadian Charter of Rights and Freedoms. The Charter, for instance, recognizes indirectly that Canada is a multinational federation through its provisions concerning Aboriginal peoples. But the main point for me here is the kind of political culture fostered in the land by Trudeau's vision and by the reform. The 1982 reform has moved us into an age of solemn, symbolic constitutional declarations. I shall call Trudeau's vision of clear, solemn, symmetrical equality for all Canadians and all provinces within Canadian federalism symétrie à la française or "French-inspired symmetry".

In our Constitution, the 1867 principle of English-inspired asymmetry, granting Québec distinct status within the Canadian federation, is opposed by the 1982 principle of French or Cartesian or Trudeau-inspired 
symmetry, rejecting any substantial and legal distinct status for Québec. Canadians have not yet found their way to French-inspired asymmetrical federalism. Although history remains open, the debates provoked by the signature of the health agreement a decade ago in September 2004, including a parallel Canada-Québec Accord on asymmetrical federalism, have taught us that getting there will not be an easy or safe journey for anyone. Between 2014 and 2017, the celebrations surrounding the $150^{\text {th }}$ anniversaries of the Charlottetown and Québec City conferences of 1864, and of course those more directly linked to the advent of our federal constitution in 1867, will provide us with numerous opportunities to further reflect on these issues. 



\section{CHAPTER 5 \\ What Canadian Federalism Means in Québec}

As a teacher, in my instructions to students as they prepare their term papers, I often remind them that they should never abdicate their judgment to the authority of one single source. In the worst of circumstances, it is much better to articulate one's own ideas and convictions than to surrender to a single book or article. In the same spirit, I would urge readers not to rely solely on my pronouncements about the meaning of federalism in Québec. In truth, this chapter's title should include a question mark, and its content will illustrate, I hope, the richness and diversity of current Québecois thinking on the subject. There are many ways as well to approach the topic at hand. I have chosen a path that reflects my academic identity as a political theorist and an intellectual historian, keenly interested in the relationship between philosophy and constitutional law in Canada, hidden in a political science department. As a reader of Gadamer and as a former student of Charles Taylor, I start with some interpretive or hermeneutical precautions. Beyond the undeniable relevance of current reflections about the theory of federalism in its most general aspects, the real question of this chapter deals with the contemporary meaning of Canadian federalism in Québec.

Constitutional experts, ever attuned to the country's mood, are all too aware that, after decades of wide-ranging discussions and reform projects concerning the fundamental law of the land, Canada now suffers from a broad constitutional fatigue (Gibbins 2009, 113). The idea of constitutional reform appears dated, passé, rendered almost unattainable through the legal and political rigidities surrounding the amending formula. Other issues now dominate the political agenda such as global environmental sustainability, securing rights in a multicultural society, and economic challenges. In Québec, something else must be added. The dream of full political sovereignty, which has occupied so many people and utilized so much energy over the past four decades, appears increasingly improbable as time goes on. Daniel Jacques and Alain Dubuc, a philosopher and a journalist respectively, and two of our most prominent public intellectuals, have recently written about the consequences of granting continued prominence to the ideal of sovereignty while its realization appears ever more unlikely. They suggest that it encourages a spirit of bad faith in Canadian politics. Witness the contradictions of the Bloc Québécois and 
how the party is perceived elsewhere. It fosters an attitude of self-contempt in younger generations attached to Québec as a nation but disappointed by the inability to realize the ultimate objective of sovereignty. Moreover, it yields to arcane idealism instead of facing lucidly and responsibly the challenges of current times (Jacques 2007; Dubuc 2008). In addition to the constitutional fatigue it shares with the rest of Canada, Québec now also seems to exhibit a kind of political exhaustion. Full nation-state status eludes sovereigntists, while federalists remain unable to achieve the kind of meaningful reform that would allow Québec to become a fully consenting partner in Canada's constitutional order. Québec is staying in Canada but its situation, as I suggest in this book, is akin to that of an internal political and constitutional exile. People are, indeed, moving to other, more pressing issues like reasonable accommodations and the challenges of diversity, the role of the state in a rapidly aging society burdened by soaring health costs and a huge provincial public debt, crumbling road infrastructures, the social consequences of religious disaffection centrally (but not exclusively) in the French-speaking majority, and the hardships of a public education system ill-equipped to promote the virtues that lead to academic excellence in a post-modern, hedonistic, and relativistic cultural, social, and global environment.

Beyond this introduction, in the chapter's next section, I specify how I understand the topic, thereby providing an interpretive context. In the second part, I survey contemporary trends and current scholarship regarding federalism in Québec. This incorporates critical reflections going beyond the description of this current literature on topics such as multinationalism and plural identities, trust and loyalty, and the whole matter concerning the rebalancing of our federal regime.

\section{Interpretive Context}

The task of interpreting the meaning of Canadian federalism in Québec is manifold. In academia, it certainly involves integrating the methods and approaches of various disciplines such as history, constitutional law, philosophy, and political science. Interest towards this topic, not surprisingly, goes far beyond academia, reaching a wider public through the media ever since the Confederation debates of 1864-1866 (Bellavance 1992; Silver 1997). At least up until the 1995 referendum in Québec and its immediate aftermath, the meaning and fate of federalism in Québec has commanded the attention of numerous scholars and intellectuals from Englishspeaking Canada (e.g., Black 1975; Moore 1997; McRoberts 1997; Silver 1982; Smiley 1980). It is an impoverishment of the topic to ignore this literature here, as I proceed to do. The same remark applies to the sustained interest in the broad topic of Canadian and comparative federalism in 
the English-speaking scholarly community throughout the land. The dean of scholars on this broad topic, Ronald L. Watts, has reprinted the third edition of his book Comparing Federal Systems (Watts 2008). In 2000, the late Richard Simeon delivered the Kenneth R. MacGregor Lecture at Queen's University, reflecting on the relationship between political science and federalism, encompassing seven decades of scholarly engagement (Simeon 2002). In 2004, the Institute of Intergovernmental Relations at Queen's University published a major collection, part of the Canada: State of the Federation Series, devoted to, and aptly titled, Reconsidering the Institutions of Canadian Federalism (Meekison, Telford, and Lazar 2004). Working respectively out of Montréal and Ottawa, Dimitrios Karmis and Wayne Norman published a major collection, providing a reader on theories of federalism in the world (Karmis and Norman 2005). Interestingly, there are three chapters by Canadians in this book, written by Ronald Watts, Pierre Elliott Trudeau, and Will Kymlicka. Obviously, the meaning of federalism in Québec is deeply related to the meaning of federalism throughout Canada, so beyond this chapter it would be quite foolhardy to ignore the multiple contributions of Canadian scholars on federalism. Incidentally, this Canadian proficiency has now reached a global stage through the immense erudition provided by the Forum of Federations in the last decade.

The meaning of federalism in Québec has evolved over time and the various travails of our common history. The classical compact theory, in its pact-of-provinces, pact-of-peoples, or combination-of-both formulae, is of course an interpretive construction that has undergone various reformulations (Kelly and Laforest 2004). Here, I only provide a few glimpses of this immensely rich literature. Around the time of our Centennial, in the mid-1960s, Jean-Charles Bonenfant, an important Laval constitutional law scholar, reflected upon the meaning of Confederation. He concluded that often in history, peoples or nations live together less out of reciprocal affection than through their inability to live separately. In 1990, in the aftermath of the Meech Lake Accord's demise, Léon Dion, co-founder of Laval's Department of Political Science, and father of Stéphane Dion, former leader of the Liberal Party of Canada, had this to say in his testimony to the Bélanger-Campeau Commission:

Québec must at long last obtain an absolute right of veto over any amendment to the Canadian Constitution. I had not hitherto seen one of the consequences that derives from these Québec demands. In the final analysis what I am rejecting is the 1982 revision of the Constitution in its entirety. English Canada ascribes great importance to the Charter of Rights enshrined by that revision. The Charter suits it well. We should not propose to amend it in various ways; we should reject it root and branch. We have had our own Charter of Rights for years. It suits us. We should strengthen its legal validity. Each person and 
group would thus appeal to a single Charter of Rights. Everybody would be better off for it (quoted in Laforest 1995b, 105).

Throughout his entire life, Léon Dion was a passionate promoter of the Canadian dream of duality. More than twenty years ago, at the height of our debate over ratifying the Meech Lake Accord, I gave a lecture about his thought in the Department of Political Science at the University of Alberta. In the passage just quoted, one can sense the immensity of his disappointment over the demise of Meech Lake and the constitutional stalemate it provoked. In a way, as I shall develop further in my conclusion, this stalemate is still with us.

The matter of federalism's meaning in Québec and throughout Canada is of course the business at hand, and many would hasten to add that it is primarily the intimate domain of constitutional law scholars. This chapter will also stay outside the technical discussions about relevance and relative strength of federalism as a constitutional principle in our fundamental law and particularly in the era of Charter dialogue (Kelly and Manfredi 2009). Constitutional jurisprudence, from the lofty statements of the Judiciary Committee of the Privy Council, to the Laskin Supreme Court in the era of Patriation, to the Lamer Supreme Court's historical reconstruction in the case of Reference re Secession of Québec, are only indirectly discussed. Historians, for their part, would be quick to invite us to consider the interpretation of Canadian federalism in a number of key commissions of enquiry over the last century, some of them in Québec, all of them involving Québec thinkers, judges, or politicians like Rowell -Sirois, Tremblay, Laurendeau-Dunton, Pépin-Robarts, MacDonald, Bélanger-Campeau, and Erasmus-Dussault. Each and every one of these commissions had something important to say about the meaning of federalism in Québec and in Canada.

Interpreting the meaning of Canadian federalism in Québec must take into consideration the fact that the country has changed a lot since Confederation. This is one of the arguments put forward by André Pratte, chief editorialist at La Presse and one of the key contributors in the Québec debate over the meaning of federalism, as I shall illustrate at greater length in the next section. For now, I will limit myself to a few major facts mentioned by Pratte. There are 47 times more people in Alberta today than at the time of Confederation, and in British Columbia the figure is 120 times. In 1901, the population of Québec was 7 times higher than the combined population of these two provinces. As matters currently stand, there are now more people in Alberta and British Columbia combined than in Québec. Within my lifetime, roughly speaking, Québec's share of Canada's total population will have declined from about $30 \%$ to $20 \%$. Comparatively speaking, it is accurate to speak of 
Québec's steady demographical and economic decline in modern-day Canada. However, for the foreseeable future, Québec will continue to play an important role in Canada's political and constitutional make-up. This much can be expected of a distinct national society of close to eight million people, operating predominantly in French, culturally and economically dynamic on the world stage, and integrating immigrants in an autonomous educational, communicational, and institutional network, in an English-French bilingual federal country called Canada. The reality of English-French duality, anchored first and foremost but not exclusively in Québec, is a major part of Canada's past, present, and future.

From the mid-1990s onwards, when I was working on the Institute for Research on Public Policy's Beyond the Impasse project with Roger Gibbins, now president of the Canada West Foundation, I coined an expression that owed a lot to my experience in Calgary: "I'd much prefer to be governed in a federal way by a unilingual Albertan, than in a quasi-imperial way by a fellow Québecer." Like many people in my province, I was disenchanted by the way in which, at least in my eyes, the Canadian government, led by Prime Minister Jean Chrétien, showed little respect for the institutions and principles of federalism in its fiscal policies, higher-education initiatives, and more generally towards its rather arbitrary and unilateral way of coordinating our political regime. As many Québecers were gradually moving away from the idea of seriously considering the sovereignty option, they had some reason to believe that Canadians beyond their province were gradually moving away from the idea of federalism as an ethical, institutional, and constitutional pillar of our system.

There is a short, simple answer to the question about the meaning of federalism in Québec, and it has been reformulated in recent years by political scientists such as Alain-G. Gagnon, Alain Noël, François Rocher, and myself: liberty and identity, autonomy and recognition. Canadian federalism, at its best, provides Québec with a substantial degree of political freedom while preserving and promoting its distinct identity. It fosters autonomy and offers an authentic form of recognition.

A quarter of a century after Lord Durham's Report and after the 1840 Act of Union, the emergence of a federal Dominion in Canada in 1867 meant, in the eyes of George-Étienne Cartier and those who sided with him, nothing less than the political renaissance of Québec and its resurfacing as an autonomous, distinct, self-governing political community. The following two passages coherently illustrate this line of interpretation. The first passage is taken from a parliamentary speech made by John A. Macdonald, while the second summarizes Arthur Silver's views about the French-Canadian idea of Confederation: 
I have again and again stated in the house that, if practicable, I thought a legislative union would be preferable... But on looking at the subject in the conference $[\ldots]$ we found that such a system was impracticable. In the first place, it would not meet the assent of the people of Lower Canada because they felt that in their peculiar position - being in a minority, with a different language, nationality and religion from the majority - in case of a junction with the other provinces, their institutions and their laws might be assailed, and their ancestral associations, on which they prided themselves, attacked and prejudiced. It was found that any proposition which involved the absorption of the individuality of Lower Canada [...] would not be received with favour by her people. (Macdonald in the Legislative Assembly of United Canada on February 6, 1865, quoted in Ajzenstat et al. 2000, 279) ${ }^{1}$

Here was the very heart and essence of the pro-Confederation argument in French Lower Canada: the Union of the Canadas was to be broken up, and the French Canadians were to take possession of a province of their own - a province with an enormous degree of autonomy. In fact, separation (from Upper Canada) and independence (of Québec within its own jurisdictions) were the main themes of Bleu propaganda. "As a distinct and separate nationality," said La Minerve, we form a state within the state. We enjoy the full exercise of our rights and the formal recognition of our national independence (Silver 1997, 41).

These two passages remind us of what Canadian federalism meant in Québec in 1867. The length of this section shows that many hermeneutical precautions need to be taken before attacking head-on the heart of the matter of what federalism may mean for us in the contemporary era.

\section{Contemporary Trends and Scholarship: Critical Reflections}

In political, intellectual, and academic circles in Québec, a federalist revival is currently occurring. I believe it is useful to start with a collection of essays put together by André Pratte. It is entitled Reconquérir le Canada: un nouveau projet pour la nation québécoise, and was released in English with the title Reconquering Canada. Reading this book, many came to the view that Canadian federalism had finally found its voice anew in Québec. Pratte and the book's contributors share four premises: it is in Québec's long term interests to remain within Canada; Québecers must change their approach towards Canada, moving beyond the language of grievances and constitutional demands; Québecers should be more active

\footnotetext{
The French version of this book, Ajzenstat et al (2004), has an additional chapter written by Kelly and Laforest, which provides a broad overview of the evolution of interpretive perspectives on Canadian federalism in Québec from the time of Confederation to the late $20^{\text {th }}$ century.
} 
participants in the political life of the country; and, Québec already possesses all the required tools to meet its contemporary challenges (Pratte 2007, 10). In short, Québec must move beyond isolationism, Québecers must be more enthusiastic Canadians, and federalists must abandon their dogmas and vanquish their fear to act and speak out forcefully on behalf of their option. In his own contribution to the book, "Faire table rase: Voir notre passé autrement pour mieux bâtir notre avenir", which translates as "Starting from the ground up: Reading our past differently in order to better construct our future," Pratte offers a lucid reassessment of Québec's situation and fate within Canada. With words echoing those of André Laurendeau at the time of the Royal Commission on Bilingualism and Biculturalism fifty years ago, Pratte invites his fellow Québecers to become more involved and take more risks in the human and social experiment called Canada. Québecers should learn more about other provinces and other Canadians, they should learn the language and the spirit of compromise, and extend a generous hand to their allies and partners in the business of this country. Québecers have constructed a distinct society, which they should be proud of, and that allows them to control their own destiny. They should act responsibly and affirm themselves through their economic progress, their dynamism, and their creativity. ${ }^{2}$ Canada has changed significantly since 1867 . Its governance is now extraordinarily complex, and in this context Québecers must abandon their past-oriented approach and the rhetoric of victimhood (Pratte 2007, 232). Invoking in his writings a historical tabula rasa as a strategic orientation for a more rewarding future, Pratte joins a number of contemporary historians and philosophers who have systematically criticized the rather nostalgic and melancholical brand of nationalism that has occupied a prominent place in Québec since the Quiet Revolution (Létourneau 2004a; Maclure 2003; Weinstock 2005).

In her chapter, "Apprendre à jouer le jeu: le défi du Québec au sein du Canada", in English "Learning the rules of the game: Québec's challenge within Canada," Marie Bernard-Meunier puts forward an appeal to the politics of reason. The complexity of federal governance is such, according to her, that such regimes can only be the choice of necessity (recall the reference to Bonenfant and the spirit of 1867 in the previous section). She sees four principles at work in the logic and nature of federalism: the locus of equilibrium in a federation will always be unstable; the cohesion of a federal regime rests on its ability to reconcile two fundamental needs, the wish of the partners to preserve their identity (rester soi-même) and their desire to pull together (s'unir); such regimes are marriages of reason,

2 See Pratte $(2006,132 ; 2007,252-253)$ and Dubuc $(2008,229)$. 
and thus, in Canada, Québecers should restrain their crippling desire to be recognized and loved; and, finally, perhaps at least partly in contradiction with the previous principle, federations require dual loyalties and senses of belonging (Bernard-Meunier 2007, 133-134). In her careful comparison of Canadian and German federal institutions and practices, she notes that in both countries a kind of natural logic towards centralization needs to be counterbalanced, and that Germany is better equipped than Canada to do this. However, in German federalism all partners play the game with an authentic, bona fide desire to share and cooperate with the others. In Canada, she concludes that Québec has broken the equilibrium between autonomy and solidarity-participation, pursuing its sole interests in an instrumental/utilitarian approach (Bernard-Meunier 2007, 140).

Relying on his vast knowledge of health politics in Canada, PierreGerlier Forest invites Québecers and their political leaders to imagine more boldly the institutions and practices of interdependence adapted to the $21^{\text {st }}$ century. In health as in other matters, he argues, Québec must move beyond the blind and mechanical repetition of its traditional demands and grievances. In his chapter, entitled "Santé: en finir avec la chaise vide", which translates as "Health policy: renouncing the empty chair approach," he proposes a typology of current understandings of federalism in Québec and elsewhere in Canada, overlapping the pole of centralization-decentralization with the symmetry-asymmetry axis. Traditionally, in Québec, the hegemonic approach towards federalism has privileged strong asymmetry with substantial decentralization. Although the interpretive panorama is somewhat more complex in Canada-beyond -Québec, Forest believes that since the advent of the 1982 Charter of Rights and Freedoms, greater centralization and greater symmetry have been put forward through a redefinition of Canadian nationalism. Forest makes an insightful point about the logic of change in a federal regime. He concludes with most experts that the burden of proof belongs to those wishing to secede from a federation. He then proceeds to add that the burden of proof should also belong to those wanting to consolidate centralizing and symmetrical dimensions (Forest 2007, 272). Justifying in pragmatic terms the respective presence of our provincial and federal governments in the field of health, in an era characterized by the primary authority of science and knowledge, Forest adds that this burden of proof should also belong to those wanting to restrain our ability to innovate and experiment with different approaches.

Much of the public interest surrounding Pratte's edited volume at the time of its publication centred on Jean Leclair's brilliant, thoughtprovoking, polemical, and at times inflammatory chapter, entitled "Vers une pensée politique fédérale: la répudiation du mythe de la différence 
québécoise radicale" or, in English, "Towards a federal political theory: repudiating the myth of Québec's radical difference." Not since Pierre Elliott Trudeau penned the chapters and articles that found their way into his own collection of articles in the 1960s entitled Federalism and the French Canadians (1968) has any Québec intellectual written such an eloquent pamphlet about the theoretical and practical merits of federalism. In truth, some parallels could be established between Leclair and his former Université de Montréal colleague, Stéphane Dion. Both march in the footsteps of Alexis de Tocqueville and Pierre Trudeau, crafting a philosophical defence of federalism for the benefit of individual freedom and multiple identities. Both see federal governance as an exercise in counterbalancing forces, promoting a political culture marked by a spirit of compromise and moderation. Beyond theory however, Dion's "Straight Talk" for contemporary Canada, to paraphrase the title of his book, is dominated by his own brand of coherent anti-separatism (Dion, 1999). His ethics and praxis of federalism look like overtures in this greater symphony. Leclair's essay, in contrast, is first and foremost an essay in praise of Canadian federalism in Québec. According to him, the understanding of Canada propounded by Québec nationalists and sovereigntists has been deterministic and totalizing, vastly exaggerating the strength of centralizing elements in the political and legal systems. He believes that these writings have also been premised on a monistic approach towards "nation" and "culture" that disregards the authentic possibility of multiple identities and develops a culturalizing pathos over-simplifying social reality. "One can only adhere to a single nation, everything is cultural in social life, and Québec is fundamentally and radically different from the rest of Canada." Such would be my summary of Leclair's overview of the premises and deficiencies of much contemporary thinking about Canadian federalism in Québec.

In order to develop a serious theory and practice of federalism in Canada, Leclair believes that it is necessary to accept a series of premises and spiritual preconditions, which are listed here:

- there are differences between human beings but, in addition, each human being is traversed by a plurality of forms and modes of belonging;

- cultural dimensions are far from exhausting the whole of reality;

- the function of federalism is to limit the power of the state as well as to peacefully structure relations between various communities;

- federalism requires a combination of autonomy and solidarity;

- a climate of tension is inescapable in any federal regime, in politics in general, and in democratic politics in particular; 
- federalism is not a zero-sum game. Canada and the central government do not win whenever Québec and its government lose, and vice versa;

- a majority of Québecers remain substantially attached to the Canadian state (Leclair 2007, 63).

Constitutional law professors, and their students, would no doubt appreciate Leclair's efforts to elaborate a balanced reading of the current state of Supreme Court jurisprudence concerning the meaning and the importance of federalism in Canadian constitutionalism. He discusses such issues as the legal anchoring of the central government's spending power, the "national dimensions" and "national emergencies" theories of interpretation, the federal jurisdiction over the regulation of trade and commerce, and over communications and concerning the implementation of treatises. On these matters, his main academic interlocutor in Québec is my young colleague Eugénie Brouillet, who is fast becoming one of Québec's pre-eminent authorities on federalism and the Constitution. Her views will be discussed further on in this chapter.

Leclair concludes his contribution with a series of reflections on what needs to be done in order to foster a greater federal spirit or political culture of federalism in Québec and in Canada as a whole. I shall limit myself here to what he says about Québec. In Québec, this would require abandoning an essentialist and totalizing approach towards culture and identity. It would require a better equilibrium between autonomy and solidarity (Leclair 2007, 65-66). Finally, it would be greatly helped by relinquishing an overly narcissistic approach on public policy dialogue. This, by the way, was one of the ideas I developed ten years ago in the Beyond the Impasse project with Roger Gibbins, advocating that federal associates should place themselves in the shoes of the other partners (Laforest 1998b, 51-52).

Ever since Confederation, as I have begun to argue earlier in this chapter, the dominant paradigm regarding Canadian federalism in Québec has been about Québec's identity, its liberty within Canada, and its autonomy (from Canada) and recognition (by Canada and/or other partners within Canada). François Rocher, a political scientist at the University of Ottawa, has written one of the most recent enlightening pieces about Canadian federalism. He believes that in both Québec and English-speaking Canada, interpretive developments are still heavily dependent, respectively, on the reports of two mid- $20^{\text {th }}$ century commissions of enquiry: the Tremblay Commission in Québec and the Rowell-Sirois Commission across Canada. I shall quote at length from Rocher's chapter:

In Québec the dominant understanding of federalism and federal institutions has its origins in the Tremblay Report, named for the chairman of the Québec 
Government's Royal Commission on Constitutional Problems, published in 1956. Since then, while evidently being adapted for particular political conjunctures, the Québec-Canada debate has taken place almost exclusively within the argumentative framework set out in that report. Similarly, the literature in English on Canadian federalism, as well as the practice of federalism by the general government, follows the argumentation advanced by the Rowell-Sirois Commission, informally so named for its co-chairmen, in the Report of the Royal Commission on Dominion-Provincial Relations, published in 1940.

To summarize my central argument in a few words: the dominant understanding of the English-language literature on Canadian federalism pays no heed to the notion of autonomy but emphasizes the notion of efficiency, while Québec Francophone scholars and the practices of the Québec government have not adequately taken into account the notion of interdependence (Rocher 2009, 98).

Healthily practicing federalism requires a form of equilibrium, of balance, between the requirements of autonomy on one side and those of solidarity-interdependence on the other. Interestingly, this remark has been recently reasserted both in a polemical fashion by Leclair, in a book quite critical of Québec sovereigntists and ultra-autonomists, and by Rocher, in the first textbook about Canadian federalism published in a long while in Québec. ${ }^{3}$ Rocher's essential point is that ever since the Report of the Tremblay Commission in the mid-1950s, there has been no such equilibrium in the work of Québec's Francophone scholars, the vast majority of whom now privilege securing and enhancing Québec's autonomy while neglecting the importance of solidarity and interdependence. I do not dwell here on the fact that the topic of Québec's autonomy was first and foremost in the Tremblay Commission's work, considering that others have adequately dealt this this subject (Noël 2007; Rocher 2009). I shall rather illustrate the preservation and strength of the same perspective in the current work of Francophone scholars in Québec, stemming from a variety of academic disciplines and working with a variety of methodological approaches.

In a work of synthesis published in 2008, summarizing three decades of teachings on Canadian federalism, my Laval colleague Réjean Pelletier squarely espouses the autonomist approach of the Tremblay Commission as depicted by Rocher. The book, entitled Le Québec et le fédéralisme canadien: un regard crique (Québec and Canadian federalism: a critical assessment), starts with the classical interpretation highlighting the

\footnotetext{
Gagnon (2009). Gagnon, Rocher and myself belong to the Groupe de recherche sur les sociétés plurinationales (research group on plurinational societies), based at Université du Québec in Montréal (UQAM).
} 
centralizing aspects of the 1867 Constitution, placing the provinces in general and Québec in particular in a subordinate position (Pelletier 2008, 14). All constitutional and institutional developments coming in the aftermath of the founding moment are essentially examined from the perspective of their consequences for the preservation and promotion of Québec's autonomy (Pelletier 2008, 54). Pelletier's book has high pedagogical value. The chapters on intergovernmental relations, bilingualism, Senate reform, the Council of the Federation, and Harper's "federalism of openness" are solid and insightful (note that I discuss some of the same issues in chapter ten of this book. Pelletier's chapter on asymmetrical federalism is an excellent example of the contemporary relevance of the Tremblay Commission's hegemonic autonomist paradigm. Supplementing the institutional development work done by Alain-G. Gagnon (2009) on the normative foundations of asymmetry, Pelletier $(2008,150)$ laments the fact that Québec has never been adequately recognized as a minority nation or as a distinct society within Canada. The book ends on a rather pessimistic note, observing that Canada's demographical and economic centers are moving further and further away from Québec. As minorities get weaker, Pelletier observes, they get less and less attention.

The study of Canadian federalism in Québec is successfully attracting a new generation of scholars. This is nowhere more evident than in the field of constitutional law, with the recent contributions from figures such as Jean Leclair (previously discussed), Jean-François Gaudreault -Desbiens (2005), and Eugénie Brouillet who co-authored the most important French-language Canadian constitutional law textbook (Brun, Tremblay, and Brouillet 2008). Brouillet has also published a book exploring Canadian federalism's legal dimensions with regards to Québec's autonomy and cultural identity (Brouillet 2005). Entitled La négation de la nation: l'identité culturelle Québécoise et le fédéralisme canadien (The negation of the nation: Québec's cultural identity and Canadian federalism), her book modified, at least in part, the traditional Québec interpretation focusing on the centralizing trends at work in the 1867 founding document. While not denying the institutional thrust of this analysis, Brouillet suggests that the $19^{\text {th }}$ century federal Constitution had much to offer for the defence and development of Québec's cultural identity. I cannot do justice here to the richness of the sections of her book that focus on the founding debates, the principles of the division of powers between the federal government and provinces, and the ways in which Québec's autonomy and cultural identity were originally secured and later enhanced by constitutional jurisprudence since 1867 . Nor can I consider her rigorous treatment of the jurisprudential evolution in the periods 1949-1982 and 1982-2005, which she characterizes as a steady dilution of the federative principle's importance in cases and matters pertaining 
to Québec's cultural identity. What I find particularly striking is the fact that, in the same spirit as found in Pelletier's monograph, Canada and its federal traditions, laws, and institutions are examined quite exhaustively, but solely, from the perspective of Québec's autonomy and distinctiveness. In a key development, Brouillet approvingly quotes the Report of the Tremblay Commission ${ }^{4}$ in support of the idea that key matters dealing with culture and societal identity were left to provinces and thus to Québec in 1867, before synthesizing an argument about the centrality of the principle of autonomy of spheres of jurisdiction to understand the relationships between orders of government (Brouillet 2005, 154-156). In these pages, she thoroughly vindicates Rocher on his point about the contemporary relevance of the paradigm clearly defined by the Report of the Tremblay Commission in Francophone scholarship in Québec.

What Pelletier and Brouillet represent, and have accomplished respectively within the spheres of political science and constitutional law, is brilliantly completed in the universe of political philosophy by my Université de Montréal colleague, Michel Seymour. In a remarkable synthesis published in 2008, entitled De la tolérance à la reconnaissance: une théorie libérale des droits collectifs (From toleration to recognition: a liberal theory of collective rights), Seymour builds on the work of Charles Taylor, Will Kymlicka, and John Rawls in an attempt to justify philosophically and legitimize politically the existence of collective self-governing rights for non-sovereign peoples (Seymour 2008). Kymlicka's approach remains insufficient for Seymour because it cannot go beyond moral individualism in its defence of minority rights within liberal theory. Seymour's argumentative strategy consists in extending to non-sovereign peoples the collective rights that the last Rawls - the Rawls of Political Liberalism and The Law of Peoples - is willing to grant to independent nation-states. ${ }^{5}$ All in all, Seymour has produced the decade's most sophisticated philosophical argument in support of greater autonomy (i.e., self-government) for non-sovereign peoples in general and Québec in particular. In 1999, at the height of a particularly acrimonious period in Canada-Québec political and intellectual debates, Seymour published a book that clearly replicated the traditional Québec perspective on Canadian federalism: an existential approach towards Québec (its autonomy and its recognition) coupled with an instrumental/utilitarian stance towards Canada. In a key passage of his 1999 book, Seymour reflects on the meaning and consequences for Canada of recognizing the

\footnotetext{
4 Government of Québec (1956), Royal Commission of Inquiry on Constitutional Problems, four volumes, Québec: Éditeur official du Québec.

5 For these two books, see Rawls (1993; 2001).
} 
existence of the Québec people. He summarizes these consequences in a list of ten points of what must be done:

1) Officially recognize the existence of the Québec people in the constitution;

2) Accept that the principle of provincial equality does not apply to Québec;

3) Accept the general principle of asymmetry in the distribution of powers and spheres of jurisdiction;

4) Formally accept the responsibilities of the Québec government in the promotion of the French language;

5) Accept that the Québec government is the only one in charge of culture, communications, and the internet on the territory of Québec;

6) Limit the spending power of the federal government;

7) Grant Québec a veto right on constitutional modifications;

8) Recognize that Québec has special responsibilities with regards to its national economy;

9) Give Québec the right to participate in the nomination of three of the nine judges on the Supreme Court; and,

10) Accept that Québec should have an enhanced presence on the international stage. (Seymour 1999, 95-96).

Recall Rocher's point about the lack of equilibrium in Québec's Francophone federalist scholarship between the goal and value of autonomy, on one side, and the goal and value of solidarity/interdependence, on the other. It seems to me that the previous list and relevant passage from Seymour's 1999 book perfectly illustrate this equilibrium. Supposing that Canada would consider accepting Seymour's various points, all enhancing Québec's perennial objectives of greater autonomy and meaningful recognition, how would this transform the way Québec and its citizens understand Canada and what would be the specific consequences with regards to obtaining more authentic forms of solidarity and interdependence within the Canadian political community? Seymour remained silent on these matters in the bitter political context of 1999. In De la tolérance à la reconnaissance, previously mentioned here, he deals mostly with strictly philosophical matters, only incidentally referring to CanadaQuébec issues to reinforce the thrust of the argument. It is, nevertheless, unequivocally a philosophical work devoted to issues of autonomy, recognition, and self-government, rather than cooperation and interdependence, as the following central passage clearly establishes. Note that the translation is mine. 
Peoples without states possess in my understanding a general, unilateral and primary right to internal self-determination, i.e. they have the right to develop themselves, economically, socially, culturally within the larger state [État englobant in French], and the right to determine their political status within this larger state. A secession right should be admitted only as a right for reparation. If the larger state refuses the representation of the minority people within its institutions, if it quashes the rights and freedoms of the citizens of the minority people, if it annexes the territory of the minority people, the latter has the right to secede. More importantly, the minority people is endowed with a right to secede seen as a right for reparation if the larger state violates the principle of internal self-determination of the minority people (Seymour 2008, 624).

Whether the emphasis is placed on approaches used in political science, constitutional law, or political philosophy, the same conclusion appears to be warranted. Francophone Québec scholarship studies Canadian federalism with an existential and Québec-centric ultra-autonomist focus, adopting an instrumental/utilitarian stance towards Canada. This orientation carries with it a number of consequences clearly discussed by Rocher:

Following from the recognition of the need for the general government to respect provincial jurisdiction, the Québec government during the Quiet Revolution demanded the recasting of Canada's Constitution in order to obtain powers that it judged to be indispensable to the affirmation of the Québec identity in all spheres of activities - economic, social, political and cultural [...] For the Québec governments, the Québec-Canada dynamic is illustrated through several concepts: attachment to the principle of autonomy, respect for and expansion of provincial jurisdictions, achieving a distinct status, and asymmetrical federalism [...] It is remarkable to note that this construction has taken place, both at the discursive level and concerning the QuébecCanada state relations, on the basis of the non-participation of Québec in the building of the Canadian political community (Rocher 2009, 106-109).

In all these affairs pertaining to trust, loyalty, and equilibrium, it is certainly wrong to put exclusive focus on one of the partners. Considering, as I do in this chapter, the evolving meaning of Canadian federalism in Québec, I could encourage readers to become blind to the fact that if indeed the federative principle's importance has been diluted in Canada's institutions and political culture, accompanied by a certain abandonment of what Rocher has called the ideal of federalism in recent decades, it is of course not only because of Québec, its political leaders, and its intellectuals. Rocher himself, in his seminal analysis, recalls that the ideal of federalism has also been abandoned by English-speaking Canada ever since the Rowell-Sirois Commission. Contemporary behavior by political elites and corresponding scholarly studies have reproduced the abandonment of autonomy - with an exclusive emphasis put on the instrumental logic 
of performance and effectiveness, which characterized the Commission's work. Notwithstanding this remark, my subject matter remains evolving ideas about Canadian federalism in Québec. Reflecting on the work of the past decade, I would suggest that, although Rocher remains correct in asserting the hegemony of the interpretive paradigm associated with the Tremblay Commission, a number of cracks exist in this model, lending credibility to the idea that a paradigm shift could occur in the foreseeable future. The work of André Pratte and his colleagues does not simply amount to an exceptional event in the quiet air of still interpretive times.

In 2005, one of Prime Minister Trudeau's former speechwriters and advisors, and a philosopher in his own right, André Burelle, published a major book in which he offered a critical re-assessment of Trudeau's intellectual and political trajectories. Marching in the footsteps of Emmanuel Mounier and Jacques Maritain, Burelle recalled the four principles of a federalist political philosophy steeped in the categories of "communitarian personalism," coined by Denis de Rougemont and others in the aftermath of the Second World War and the dawn of Europe's reconstruction. These principles are summarized as follows:

1) In a liberal-democratic federal regime, the ethical anchor of just relations between citizens and federated communities should be the principle of equivalent treatment rather than identical (uniform, symmetrical) treatment, because whenever we treat in a uniform way beings and agents who are not identical, we negate their difference and we cease to pursue the federal goal of union without fusion;

2) Subsidiarity should be entrenched as a founding principle to establish the sharing of jurisdictions between federal governmental partners. In order to maintain the exercise of power as close as possible to human beings and communities of close proximity, matters should be allocated or transferred to the central authorities only when they cannot be dealt with appropriately (in a just and efficient way) at the local level;

3) Non-subordination should be entrenched as a founding principle with regards to the sharing of sovereignty. The establishment of peaceful and creative cohabitation between federal partners requires that none of the orders of government should be subordinated in law or in practice to the other in the exercise of their respective constitutional powers; and,

4) Co-decision should be established as the founding principle for the management of interdependence between partners in the federation. In order to respect the previous principle (i.e., nonsubordination), federal partners should decide jointly the nature 
and scope of the constraints that each is prepared to accept in the exercise of one's sovereign powers to solve the problems that they also share jointly when their respective jurisdictions meet one another (Burelle 2005, 44).

Interestingly, Burelle shares many of the critical judgments concerning Canada's evolving federation that can be found in many contemporary studies faithful to the traditional Québec autonomist interpretive canon, such as Pelletier, Brouillet, and Seymour. Like most analysts, Burelle believes that there was greater respect for the principles he cherishes in the 1867 Constitution than when Canada was constitutionally re-founded in 1982. However, he is much more vocal and lucid than anybody else about the need for a new equilibrium between the requirements of autonomy and those of solidarity-interdependence. Over the past decade, without concrete results much to his chagrin, Burelle has advocated that Québec governments should open talks on this idea of a new equilibrium, demanding the constitutional recognition of Québec's right to national difference (a difference that comes with legal and political consequences beyond simply symbols), while at the same time accepting the aforementioned principle of co-decision in the management of economic and social interdependence (Burelle 2005, 467).

In many ways, Burelle remains an idealist about federalism as a doctrine and in his understanding of Canada's 1867 Constitution. Thus, I find it useful to read his prose alongside that of Christian Dufour, who has been intelligently studying the histories and collective identities of Canada and Québec for twenty years. While Rocher and Burelle talk about equilibrium between autonomy and solidarity/interdependence, Dufour, without relinquishing the need for such balance, prefers to talk about the twin projects of sharing and separation (Dufour 2000, 105). Without a doubt, federal partners indeed need to share, but they also require separate rooms in their joint political home where they have enough space to conduct their own affairs. Because the language of separation is stronger than the vocabulary associated with autonomy, Dufour remains suspicious about Burelle's principle of subsidiarity, considering that it may yield too much in the name of greater efficiency. Dufour, however, becomes a nice companion to Burelle's reflections when he notes that Québec's lack of participation in the Canadian state over the last twenty-five years has contributed to the weakening of the federal principle across the country, importantly recognizing as well that Québec's approach to the Canadian federal project is partly out-dated (Dufour 2000, 106-108).

Dufour also brings a welcome touch of historical realism to the whole discussion when he recalls the intertwinement of Canadian and Québécois collective national identities, and the key role of Québecers 
in the founding and development of both of these identities. The contemporary Canadian national identity has been created and transformed ever since the $18^{\text {th }}$ century through historical events that took place largely, if not exclusively, on Québec's territory. Particularly following the Quiet Revolution, a Québec national identity came to dissociate itself to a substantial extent from the Canadian national identity, though the latter has kept much greater relevance in the hearts and minds of Québecers than many, especially in the sovereigntist intelligentsia, have been willing to recognize. In Dufour's words, most contemporary Québecers are also the deepest-rooted Canadians, and this explains why it has remained extremely difficult to make them renounce their Canadian allegiance. If this is the source of profound misunderstanding in Québec, the equivalent elsewhere in Canada takes the shape of an immense difficulty, in light of Québec's role in the transforming of Canada, in embracing Québec's right to difference and the idea that this should have meaningful political and legal consequences. Both Dufour and Burelle were advocates and admirers of the ill-fated Meech Lake Accord. They believe that the Accord was the best attempt to modernize the Canadian federal project in agreement with the principled ideals of federalism and the realist surroundings of our historical trajectories. Taken together, Burelle and Dufour provide a nice starting-point for those who would attempt to modernize the paradigm of the Tremblay Commission.

It would be impossible to revisit the developments of the last decade without attempting to assess the ideas and the contributions of the former Liberal Québec government led by Jean Charest. First elected in 2003, reduced to minority status in 2007, and having climbed back to an albeit modest but real majority position in December 2008, the Charest government inherited Québec's traditional autonomist position and demands in the Canadian federal dialogue. Benoît Pelletier, constitutional law scholar and Québec's Minister of Intergovernmental Affairs between 2003 and 2008, claims that the Charest government attempted to respect the federalist tradition of the Québec Liberal Party using three principles:

Affirmation -because Québec has every reason to be proud of its identity and to want to reinforce it and have it resonate both in Canada and around the world.

Autonomy -because being a federalist means believing in autonomy. Indeed, federalism postulates that the provinces' autonomy is just as important as that of the federal order of government. Québec is an autonomous entity within the Canadian federation. The Government of Québec is committed to defending this autonomy, and even extending it, in part through nonconstitutional means, such as the signing of administrative agreements. The 
current Québec government defines the term 'autonomy' from a resolutely federalist perspective.

Leadership -because Québec must resume the leadership position that it held historically within Canada, both in its relations with other provinces namely interprovincialism - and in its dealings with Ottawa (Benoît Pelletier 2009, 471).

Almost a decade after their first electoral victory, how can we assess the performance of Jean Charest's Liberals in revitalizing Canadian federalism? The results are far from insignificant. They include: the 2003 creation of a new body aimed at streamlining horizontal interprovincial and intergovernmental relations, the Council of the Federation; a major agreement towards the financing of the health system with the central government in 2004; formally recognizing the principle of asymmetrical federalism in a parallel deal with Québec in 2004; a 2006 CanadaQuébec agreement paving the way towards the participation of Québec in UNESCO forums; the motion adopted by the Canadian Parliament in 2006 recognizing that the Québécois form a nation within a united Canada; and, the partial overhauling of fiscal relations between the central government and its partners in 2007. Experts have analysed in depth most aspects of this performance. ${ }^{6}$ Beyond these segmented evaluations, it is worth noting that the Liberal Government in Québec between 2003 and 2012 modified this federalist rhetoric in their last years in power. In a major speech delivered in Toronto during the October 2008 federal election campaign, entitled "Reinventing Canada: the Challenges of our Country for the $21^{\text {st }}$ century," former Minister Pelletier clearly modified the structure of Québec's traditional federalist discourse. Habitually, this discourse is "existential" about Québec, emphasizing the twin mottos of autonomy and recognition, while simultaneously adopting an instrumental/utilitarian stance towards Canada. In his Toronto speech, Pelletier started with a reference to Canada as a country that "we build and share all together" (Pelletier 2008, 2). Obviously, he did not neglect the objectives of autonomy and recognition, but he started by talking about the management of interdependence and cooperation. With regards to the national identities of Canada and Québec, Pelletier insisted that they did not need to conflict and that they could enrich each other inasmuch as the “affirmation of Québec's distinct national character could be conciliated with the pursuit of a Canadian common project" (Pelletier 2008, 5).

Just over a decade ago, Alain-G. Gagnon and James Tully published a major collection on multinational democracies (Gagnon and Tully 2001). At the crossroads between comparative political science and political

$6 \quad$ See, Pelletier (2008) and Laforest and Montigny (2009). 
philosophy, this research endeavoured to study political and constitutional developments mostly in advanced democracies such as Belgium, Canada, Spain, and the United Kingdom. Gagnon has produced significant academic outputs in running major inter-university collaborative efforts out of Montréal. ${ }^{7}$ In the deliberative public spheres of complex democracies, the flagship of multinational federalism is often carried with greater enthusiasm by academic leaders within minority nations, as seen in the cases of Alain-G. Gagnon in Québec-Canada debates and Ferran Requejo in Catalonia-Spain debates (Gagnon 2007; Gagnon and Iacovino 2007; Requejo 2005a). Logically, it would be only normal to expect these academic leaders to reproduce in debates surrounding multinational federalism the hegemonic categories of internal debates within their respective national communities. Keeping in mind what Rocher had to say about Québec's interpretive federalist traditions, let us consider the following excerpts from a book by Gagnon and Iacovino:

As this overview of Canadian constitutionalism will show, Québec's position with regards to its place in Canada has survived generational shifts, international political transformations, and mostly, domestic social currents both in the larger Canadian context and in Québec, demonstrating remarkable consistency with regards to its existential standing. From both a socio-historical and historical-institutional perspectives, Québec's place in Canada has rarely shifted, and when it has, it has been a matter of degree as opposed to a wholesale reconceptualization (Gagnon and Iacovino 2007, 22).

It is time for both parties to take the high road [...] Canada must understand that Québec's affirmation is not inimical to the preservation of the country. It is not a zero-sum game. The extent of association, however, must be negotiated before the level of mutual confidence and trust that bind the political communities together are severed beyond repair. This is a key step, since the will to live together may not be sufficient once that symbolic threshold is crossed. The high road is a two-way street. Québec must make additional efforts to assure that its minorities are represented in the process of formally constituting itself. Its relationship to the rest of the country ought to be deliberated in a more legitimate procedure than a mere referendum question would imply. And its solid record in respecting liberal democracy ought to remain unblemished. The formal constitution process puts all of this on the table. With regards to Canada, whatever negotiating partner emerges, whatever procedure is adopted, one clear principle must take precedence; it must internalize the notion that it is not ratifying and subsequently negotiating a new deal

Among other members of the Groupe de recherche sur les sociétés plurinationales (research group on plurinational societies), previously mentioned here, and the Centre de recherche interdiscipinaire sur la diversité et la démocratie (Interdisciplinary research Centre on diversity and democracy). These groups are better known by their respective acronyms in French: GRSP and CRIDAQ. 
as a majority. It must begin to see itself as a partner, in the spirit of dualism to which Québec has always adhered. They may not ratify the document, or reject the process altogether, but in the scenario outlined here, this would only hasten the rupture (Gagnon and Iacovino 2007, 174-175).

I believe that the tensions and contradictions that can be perceived in these passages reinforce the idea that the ground is slowly but effectively moving in Québec and that the current era could indeed witness an important paradigm shift. The first passage is all about continuity, much in the spirit of the Tremblay Commission and of its legacy as critically analyzed by Rocher. The second passage does not totally depart from this view. Consider, for instance, that the Canadian partner must accept the dominant Québec view of dualism. It nevertheless does also insist that all players in this democratic deliberation should take the high road, that the whole matter is a two-way street insisting on the key notion of reciprocity, with everything on the table, and that all partners should display imagination and courage. These latter elements were more consistently present in the introduction and conclusion of Gagnon's book published under the auspices of the Institut d'Estudis Autonomics in 2007, for which he obtained the first Josep Maria Vilaseca I Marcet Prize (Gagnon 2007, 15, 179). Our political and intellectual communities will be hard-pressed to display such imaginative boldness in the 2010s.

\section{Conclusion}

I have argued in this chapter that interpreting the meaning of Canadian federalism within Québec is at a crossroads. While the traditional, strictly autonomist paradigm of the Tremblay Commission still dominates in key disciplines like political science, constitutional law, and political philosophy, rich internal debates within these disciplines indicate that a major paradigm shift could be looming (Graefe 2009). Quite naturally, as often happens in the humanities and social sciences, not everything will change simultaneously. In both Francophone Québec and Englishspeaking Canada, the dominant interpretive traditions are deeply rooted and will not be easily displaced. If it were possible to muster sufficient space and intellectual resources, it would be interesting to see if Rocher's argument about federalist traditions in Canada can also be applied to the political and intellectual lives of other multinational societies in places such as Belgium, Spain, and the United Kingdom. My hunch is that it can, allowing us to see that, in the dialogue between minority and majority national political communities, most authors (scholars, intellectuals, and politicians) have formulated their interpretation of their shared tradition of federalism or partnership, broadly speaking, with an instrumental (or thin) perspective if they are part of the majority and with an ontological 
identity-defining, thick perspective if they are part of the minority. This explains some of the major misunderstandings between interpretive communities.

Focusing mostly on the Francophone interpretive community in Québec, I have examined here, following Rocher's groundbreaking work, some of the intellectual shortcomings of this tradition. Of course, as Gagnon and Iacovino adequately insist, this whole affair is a two-way street and the English-speaking interpretive tradition is not devoid of its own shortcomings. Moreover, as Alain Noël has argued in his own assessment of current scholarly debates about multinational federalism in Canada, these debates are always complex affairs, combining normative considerations and power politics between governments and between majorities and minorities. They always are, simultaneously, associating the power of arguments with the arguments of power (Noël 2006, 422). Considering all the constraints that limited their capacity for action and innovation, Noël suggests that $19^{\text {th }}$ century politicians from Canada and Québec did a reasonable job in their own deliberations and that these could possibly inspire us in our own times:

For all its democratic limitations, the constitutional politics of the late nineteenth century followed a path that was neither 'analgesic' nor 'agonistic.' Anchored in the immediate preoccupations of politicians and informed by the need to find workable accommodations, the process nevertheless displayed a tension between the principled search for uniformity typical of modern constitutions and the equally principled demands for recognition and for the preservation of diversity that were anchored in the country's ancient constitution. This tension pitted the idea of a new nation against the protection of established ways of life, and confronted the elites of the new state with the complex requirements of popular consent in a multinational federation [...] Like all deliberative processes of significance, the Canadian constitutional debate never was a nice and polite conversation, carried by well-meaning participants who had previously checked their interests and their advantages at the door. It often involved tough bargaining or verged on plain domination, was always less than perfectly democratic, and incorporated many restrictions and constraints that disadvantaged some or many constituents. This debate, however, was also anchored in principles about democracy, continuity and consent, and it contributed to the establishment of important rights and relatively satisfying institutions and practices. This deliberative process was, in other words, a real political process. And it mattered very much (Noël 2006, 438).

This deliberative process is still going on and it still should matter to us in 2014, with all kinds of new constraints in a transformed Canada, a transformed Québec, and a globalized world. Be they majorities or minorities, national communities are always structured around the equilibrium between the pull of the past, of heritage and memory, and the pull of 
their projected futures. Will these futures be characterized by the mechanical repetition of the dialectic of conquest and reconquest, premised on the idea of domination, or a by a more edifying politics of concord and reconciliation? We can never be completely certain about these matters in human affairs. However, I am quite convinced that if the politics of concord and reconciliation are to prevail in Canada-Québec debates, the political leaders of these societies and the scholars of the two major academic communities must agree, respecting Burelle's principle of co-decision, on the appropriate disentanglement between utilitarian issues that can be governed by the categories of thin, instrumental rationality, and existential matters that will demand the ability to speak the thick language of authentic allegiance for their shared and intertwined collective national identities. It will not be a simple process. As Noël reminded us, it was also far from being simple at the time of our federal founding in 1867. 



\section{CHAPTER 6 \\ Lord Durham, French Canada, and Québec \\ Remembering the Past, Debating the Future}

It remains immensely worthwhile in our times to read Lord Durham's Report, for social scientists as well as for anyone who has a general or scholarly interest in politics, philosophy, and history. Its edifying power is first aimed towards a global public, reflecting in vexing circumstances upon the appropriate remembrance of a troubled past and seeking ways of delineating the moral and political consequences flowing from specific ways to interpret historical facts and events. We deal here with the contours of a perennial philosophical debate, attempting to make sense of the relationship between history, memory, and politics. To show why the Durham Report is as indispensable as ever for political theorists of all stripes, I will slightly reformulate a question that is a recurrent theme in Janet Ajzenstat's introduction to the 2006 edition of Lord Durham's Report. Can the universalistic pull of liberal modernity be reconciled with the preservation of particular identities and cultures? In the past twenty years, this question has been a central issue in the Republic of Letters. It is no mere coincidence that Canadians have played leading roles in such a debate (Beiner and Norman 2001). For quite obviously to the readers who have journeyed through this book, the pedagogical value of the Durham Report is nowhere more important than in Canada and Québec.

In 1963, when the Report was last edited in English, Québec was going through the political process of late and brutal modernization, known as the "Quiet Revolution" (Gagnon 2003a; Simard 1999; Cook 2005). Canada as a whole was a country moving equally rapidly, on the eve of the 1967 Centennial of Confederation, towards its own national identity increasingly separated from Britain. Readers will recall that it was in 1963 that the Government of Canada, led by Prime Minister Lester Pearson, put together the Royal Commission on Bilingualism and Biculturalism, co-chaired by Davidson Dunton and André Laurendeau and whose mandate was based on the idea of an equal partnership between Canada's French-speaking and English-speaking founding peoples (McRoberts 1997, 38-41). It is naturally beyond the scope of this chapter to address at length the political evolution of Québec and Canada from 1963 to the 
present day, although I do not completely ignore it either. ${ }^{1}$ It will suffice at this stage to mention that this new edition of the Report, in its own right a commemoration of Durham's legacy in these lands, came out at about the same time as two major historical celebrations. The first was the $400^{\text {th }}$ anniversary of both Québec City's and Canada's foundings by Champlain in 1608 . The second was the $25^{\text {th }}$ anniversary of the 1982 Constitution, the last step in Canada's adventure of quietly decolonizing from Britain and the dawn of the Canadian Charter of Rights and Freedoms era. Today, as in 1963 and in the epoch of Durham, the historical paths of Canada and Québec remain intertwined as they jointly struggle for greater political freedom and to secure distinct identities in the Americas.

My argument here is thus premised on the idea that the Durham Report has universal and particular meanings. As debatable and contradictory as these meanings may prove to be, I do not pretend to close the debate. But is my hope that fifty years from now, readers will still find in my reflections useful notes and arguments to make up their own minds.

I will logically start with the fate of the Report in French Canada and Québec, attempting to assess how it has been viewed by previous generations and how it is being discussed in current historiographical debates. Variations are aplenty, but the basic idea remains the same. Lord Durham and his Report are causally connected to the emergence and the development of a specific form of national self-consciousness. After looking at this, I discuss and attempt to complete some technical points on the views put forward in the introduction of Janet Ajzenstat (2006), starting with the key figure of Étienne Parent. Much of what my colleague says throughout her introduction about the meaning of the Durham Report for Canadian history and the evolution of federalism is very enlightening. I will add my perspective to her general view. Following some notes on Durham as a human being and as a thinker, I shall focus on two themes: (1) the place of the Durham Report in one of Québec's most important ideological and intellectual strands, "melancholy nationalism" (an expression developed by political philosopher Jocelyn Maclure), and (2) the fundamental tension between universalistic and particularistic aspects in the tribulations of modernity, a key feature of the Report, and how it is being played out in Canada and Québec (Maclure 2003, 19-59). ${ }^{2}$

\footnotetext{
1 Up-to-date political science textbooks are the right place to start addressing this question. See MacIvor (2006) and Pelletier and Tremblay (2005). For my own views, see Laforest (2004, 325-355).

2 As Maclure acknowledges, it must be said in fairness that Jocelyn Létourneau had previously and critically established a link between misery and melancholy in Québec's historiography. See the essays collected in Létourneau (2004a).
} 


\section{Coming to Terms with Lord Durham's Report in French Canada and Québec}

Canada is a member of the elite G8 group of industrialized states in the global internet age. Québec is a majority French-speaking province in a federal, highly developed country that prides itself on official bilingualism. A key aspect of this is the existence of two autonomous but equally interconnected public spheres with two communication and scientific networks operating in these great languages of Western modernity, English and French. The march of this societal environment, from 1963 to now, is bound to have produced greater academic and scholarly sophistication in all fields. History, the art of understanding the past, has not been left behind in this evolution. The task of revisiting the Durham Report has been made even more challenging by the complexity and vigour of historiographical debates throughout Canada and singularly in Québec. ${ }^{3}$ There has also been, since the last English edition of the Report, a quantum leap in the international academic community's level of interest in Canadian affairs. To highlight the perennial importance of Lord Durham and of the constitutional blueprint springing at least partly from his Report, I start with one such foreign voice, that of Dresden-based Professor Ingo Kolboom:

For French Canadians, it was the genesis of a historical trauma. The repression of the Patriotes and the sanctions on French Canadians, institutionalized by the Union Act in 1840, have been their true historical defeat, inasmuch as these events were perceived by them as a traumatizing deception visà-vis the British, who revealed themselves to be the Conquerors of 1763 . French Canadians re-lived through the sanctions of 1840 the defeat of 1760 (Kolboom 2001, 192) ${ }^{4}$

I consider Kolboom's interpretation in this passage as the hegemonic view about Lord Durham and his influence throughout French Canada and Québec's history and intellectual life. Durham's legacy has been made even more present in academia in the last decade, due to a rejuvenated interest in political history and a corresponding decline of a more positivistic and technically oriented economic and social history. ${ }^{5} \mathrm{On}$

3 To grasp the basic trends in the historiography of Québec, see Rudin (1997) and Gagnon (1982; 1985).

4 I find a clear and coherent expression of this dominant view in Dufour (1990, ch. 3). Even those who disagree with this paradigm agree on its centrality. See, Létourneau (2004b).

5 This recent development is discussed in Kelly (2003, 1-11). See, also, Kelly and Laforest (2004). The return of political history is illustrated and discussed in a series of new journals that have emerged in Québec in the last decade: Argument, Bulletin d'histoire politique, Mens: revue d'histoire intellectuelle de l'Amérique française, 
Durham as on other matters, Québec and other Canadian historians now engage in more frequent and energetic debates, searching for insightful challenges to the historical myths at work in their respective communities (Meisel et al. 1999).

I shall now briefly consider two questions stemming from these recent exchanges. The first issue is defined by attempts to establish the primary cause of the 1837-1838 rebellions. Was the crisis fundamentally linked to political reasons or was it rather, as Lord Durham forcefully argued, the apotheosis of a long-standing and insurmountable ethnic conflict? Allan Greer, historian at the University of Toronto and an expert on the rebellions in Lower Canada, has this to say about the archival evidence on this matter:

An influential school of thought in Canadian historiography that dates back to Lord Durham and others says that all fine phrases about political rights and freedom spouted by the patriots were a cover for an essentially xenophobic movement, and that what is fundamental in Lower Canada is the conflict of English and French. Everything else is secondary. I would argue that the argument is almost exactly the reverse of reality [...] The conflict that came to an acute stage in 1837 and 1838 had everything to do with the breakdown of politics as usual and a crisis of the state, which called forth a mobilization of the majority of the population [...] The really acute strife and conflict between English and French came after that; it followed from that fundamentally political conflict $[\ldots]$ What seems to have resulted is something that happens in a lot of revolutionary crises in other parts of the world and other eras of history. Ethnic and linguistic minorities became quite uncomfortable, as a reaction to the revolutionary process itself. ${ }^{6}$

The myth that Greer helps dismantle regarding the source of the conflict is not the only one to have survived until quite recently. Obsessed by Durham's scathing language throughout his Report and by the cold severity of his prescription concerning assimilation, French Canadians and Québec thinkers have tended to portray him as a formidable figure. Fernand Dumont poignantly summarizes this trend when he characterizes Lord Durham's implacable logic and "remarquable hauteur d'esprit" (remarkable elevation of spirit) as nothing short of immense (Dumont 1993, 128). Durham as a spiritual semi-God? John Ralston Saul begs to differ with this judgment:

Cahiers d'histoire du Québec au vingtième siècle. For developments throughout Canada, see Owram (1997).

6 These excerpts are taken from an interview with Allan Greer in Bothwell (1995). A lengthier discussion can be found in Greer (1992). 
In a way our attitudes can be summarized through our relationship to Lord Durham. We have turned his four-month visit during 1838 into the touchstone of the Canadian condition [...] The words aimed at francophones have been particularly retained by part of their elite as a sore to be scratched open on a regular basis. But consider the real Durham, beyond mythology. He was neither a great figure nor a great aristocrat. He inherited money and through political activity was paid off with a title. He was of marginal junior-minister importance $[\ldots]$ His one original idea - the union of the two provinces would provoke the assimilation of the francophones - was completely wrong [...] This is the context in which Durham's gratuitous insults must be seen. It was just the sort of language you'd have expected from an immature graduate of Eton in the nineteenth century [...] The combination of personal privilege, marginal success, an unstable personality and class prejudice are enough to perpetuate this sort of juvenile wilfulness in a man who cannot engage with reality (Ralston Saul 1997, 363-365).

Ralston Saul has indeed a point, although I do believe that there is room for greater nuance in assessing Lord Durham as a human being and as a thinker. The goal of such a careful re-examination requires a journey through current historiographical developments. McGill Professor Yvan Lamonde is Québec's pre-eminent historian of ideas and the road towards a more balanced evaluation of Lord Durham's Report passes through his scholarly accomplishments. Lamonde (2000) has notably written a masterful synthesis on the $19^{\text {th }}$ century. ${ }^{7}$ Aside from his impeccable bibliographical work, Lamonde's essential contributions include a precise chronicling of the mounting dissatisfaction of Lower Canada's colonial elites vis-à-vis metropolitan authorities in the 1830s; a much needed identification of the intellectual climate of the rebellions through a detailed examination of the printed sources at the disposal of Lower Canadians in order to establish their knowledge of contemporary developments and struggles in the Americas and Europe; a deep analytical and contextual analysis of the political thought of Étienne Parent and Louis-Joseph Papineau (their personal intellectual evolutions, the transition from their close collaboration to their estrangement in the camps of moderation and revolution, and their opinions on Lord Durham's mission during his sojourn in the Canadas and their reactions to his Report); and, finally,

7 For an annotated introductory bibliography on Québec, start with Gagnon (1998). For a summary of Lamonde's own bibliographical progress on the history of ideas in Québec, see Lamonde (2003, 11). Étienne Parent (the learned journalist and moderate constitutionalist) and Louis-Joseph Papineau (the great Parliamentarian turned rebel and exiled radical republican) are the most important of Durham's contemporaries in Lower Canada. Lamonde has rendered it much easier to comprehensively understanding their intellectual evolution. See Étienne Parent's Discours in an edition prepared by Yvan Lamonde and Claude Couture (2000). See, also, Lamonde and Larin (1998). 
a lucid understanding of the complex reasons explaining the failures of the rebellions (Lamonde 2000, 183-282). ${ }^{8}$ Indispensable on any topic, Lamonde makes one key point about Lord Durham that can easily be neglected by $21^{\text {st }}$ century readers. Durham did not belong to a neutral, fact -finding commission of the International Court of Justice in The Hague trying to assess the causes of a conflict, to impart responsibilities, and to devise the contours of a durable and just institutional peace respecting the premises of human rights conventions. Rather, Lord Durham was first and foremost a British imperialist, culturally and politically biased about the matters he had to enquire and report about. This is particularly obvious, according to Lamonde, in his lack of critical judgment towards the Legislative Council, the one colonial institution that Lower Canadians had constantly identified, starting with Pierre Bédard in 1814, as an essentially English ethnic structure, in contradiction with the spirit of British constitutionalism (Lamonde 2000, 261).

French Canada (rather than Lower Canada, this is a fundamental distinction) as a self-conscious national community begins with Lord Durham's Report and its political consequences. Starting with the nostalgic, quasi-Romantic figure of François-Xavier Garneau, and all the way to the post-1945 Montréal School (Maurice Séguin, Guy Frégault and Michel Brunet, a generation obsessed by the negative consequences of the Conquest which has set the stage politically for Québec's post 1960 independence movement) and its Laval counterpart (Fernand Ouellet, Jean Hamelin, pioneers of a more positive evaluation of the British regime and of Canadian Confederation), historians have dated back to the early 1840s the birth of an ideology or doctrine of national survival in French Canada. This ideology gave priority to the conservation of the community's cultural, linguistic, religious and other traditional institutions, fostering a program of survival that seems to confirm Lord Durham's verdict by delineating a national life mostly away from the struggles of liberal politics and from the challenges of market economic practices in America. Lord Durham and his Report have remained alive in all phases of this historiographical saga. Beyond academia's walls, for those who would venture to enquire about the centrality of Lord Durham's legacy for contemporary Québec society, I now summarize books by the late Fernand Dumont and by Gérard Bouchard, two major thinkers who have acted as public intellectuals while enjoying wide respect from their peers.

Both Dumont and Bouchard have supported or do support the project of political sovereignty for Québec. For both thinkers, philosophically,

Two recent and enlightening essays attempting to further Lamonde's work in his areas of originality are Harvey (2005) and Bellavance (2004). 
independence is the political telos of political modernity. Nations are fully normal and healthy when they are completely sovereign. Trained in anthropological philosophy, psychology, and sociology, Dumont, in his own master narrative entitled Genèse de la société québécoise (Genesis of Québec society), has emphasized Lord Durham's role in the production of key pathologies of individual and collective historical consciousness in French Canada. Dumont integrates all the elements that led Durham to his prescription of forced assimilation: the spirit of contempt and disrespect for most things French Canadian and the disparaging comparisons and the prophecies of inevitable doom in America. He thus places Durham at the loftiest level of the British (later Canadian) Other par excellence of French Canada and French Canadians. This negative discourse of assimilation, based on irrevocable inferiority, has been slowly, subtly, and systematically internalized by French Canadians venturing to formulate their own discourses of national self-consciousness (Dumont 1993, 123-138). ${ }^{9}$ The Durham Report led to their permanent political subordination and to the development of a profound minority complex. I will discuss in the next section some problems associated with Dumont's narrative. My argument here is simply to reiterate that Lord Durham is directly linked by Dumont to the existence of a deep problem of false consciousness in the historical trajectory of French Canada and of Québec the kind of problem that could only be cured by sovereignty. Whatever one may think of the validity of its thesis, Dumont's book remains quite useful for comprehensively discussing historical materials, particularly regarding the generation of François-Xavier Garneau who lived in the immediate aftermath of Lord Durham's Report and had to interpret - nay, in truth, had to invent narratively - French Canada in his shadow. I now turn briefly to the work of Gérard Bouchard.

Trained in sociology and history, Bouchard provides a nice complement to Dumont's approach. Whereas the latter is fascinated by the unfolding dramas of subjective consciousness, Bouchard is more interested in the apparently more objective comparative analysis of the structural patterns at work in the evolution of modern societies. In his magnum opus, Genèse des nations et cultures du nouveau monde: Essai d'histoire comparée (Origins of the New World nations and cultures: an essay in comparative history), published in 2000, Bouchard studies the historical trajectories of Canada and Québec by contrasting them with movements and trends in Australia, Latin America, the United States, and New Zealand. His excellence in the art of synthesizing intellectual doctrines is illustrated

For a critical yet sympathetic introduction to Dumont's project, see Beauchemin (2001). See also, "L'hiver de la mémoire" in Warren (1998). 
in his very useful analytical summary of the doctrine of la survivance for French Canada, the paradigm of survival for a national culture and a collective memory (Bouchard 2000, 107-110). For Bouchard, Québec is essentially the sole exception in a pattern that saw the full political emancipation, most often through processes of radical rupture, of all New World collectivities subordinated by European empires. In this narrative, Lord Durham and his Report stand at a critical historical juncture, one which saw a definitive bifurcation in Lower Canada's march towards full societal and political maturity (Bouchard 2000, 98-99). There is indeed a teleological philosophy of history at work in Bouchard's reflections, one which sees Québec's sovereignty as a normal end-point fulfilling the promises of its roots and destiny on the American continent. ${ }^{10}$ How does Lord Durham fare, ultimately, in the works of these two widely admired figures of Québec's sovereigntist intelligentsia? In Fernand Dumont's elegant prose, the figure of Durham is respected, critically dissected without being demonized. In Gérard Bouchard's more coldly scientific yet equally compelling narratives, Lord Durham is almost completely ignored but the consequences of his thoughts and actions are omnipresent. In both cases, all in all, his name remains associated with the dark side of the past.

\section{Janet Ajzenstat's Introduction: Debating Lord Durham's Influence on Canada and Assessing Him as a Human Being and as a Thinker}

Janet Ajzenstat (2006) is quite right to insist in her introduction on the exemplary role of Étienne Parent, editor of the newspaper Le Canadien in the 1830s and arguably Québec's first real intellectual (Bergeron 1994). Throughout the decade, Parent attempted to articulate for himself the view of the reasonable middle ground, marching in the footsteps of Bédard and thus embracing British constitutionalism, while attempting to balance his support for Enlightenment liberalism and a defence of Canadian nationality (la nationalité canadienne, as it was referred to in pre-Durham years). In April 1837, when it became clear following the Russell Resolutions that metropolitan authorities in Britain would remain deaf to the grievances of Lower Canada, Parent advocated renewed prudence. He warns his compatriots that they should beware of suffering a fate similar to that of Poland in 1831 at the hands of despotic Russia. In some circumstances, writes Parent, "there is first such a thing as an honourable submission

10 This interpretation is shared by both sympathetic and more critical readers of Bouchard. This is demonstrated, respectively, by Beauchemin (2002, 142-143) and by Létourneau (2004a, 55-64). To gain a sense of Bouchard's position among Québec historians, see Bédard (2001). 
and secondly a dishonourable domination" (Parent 1999, 100). In the aftermath of Lord Durham's Report, as Ajzenstat remarks, Parent had indeed his great moment of despair, coherently contemplating the inevitable disappearance of la nationalité canadienne and the assimilation of his compatriots. The history of Canada would not have unfolded in the same manner if Parent had not found ways of reconsidering this bleak judgment, as Ajzenstat (2006) clearly articulates. She fails however to mention that Parent lived through his darkest hour while he was in jail. He remained in custody, from late December 1838 onwards, for a period about as lengthy as Durham's own stay in the Canadas. The conditions of his imprisonment were what they were at the time in a tough, colonial winter and he became deaf. Parent was jailed, not on Durham's orders, for he had gone back to Britain two months earlier, but because of an article he had written in Le Canadien, arguing in quasi-Lockean terms that the real conspirers, those who carried primary responsibility for the disturbance of order, were the persons in authority who had multiplied provocations, pushing the people from excesses to new excesses with harshness and renewed harshness. ${ }^{11}$ Parent despaired after repressive terror was used to crush and subjugate him. Durham and his era are more than a chapter in the history of the liberal doctrine. These were dark times and Parent, as Greer remarks, was not the only one to suffer from the politics of terror.

There was another version of terror, the counter-revolutionary terror, that occurred after the patriots were defeated, and that took very harmful forms. Houses were really burned down, by the dozens, possibly by the hundreds in the wake of the fighting in 1837-1838. People were killed, people by the hundreds were thrown into jail. Many were taken into custody, probably thousands, for shorter periods, although it was not well recorded. So the population in the District of Montréal, in the rural areas, was well and thoroughly frightened into submission by these tactics (Bothwell 1995, 33).

Near the end of her introduction, Ajzenstat seems to suggest that Lord Durham, trying to preserve the safeguards of the parliamentary system, coherently dismissed the potential intolerances of the French majority and the flaws of Lower Canada's colonial regime. In this logic, she writes, "Unconstrained rule by the French majority would soon become as intolerant as unconstrained rule by Governors and their cronies" (Ajzenstat 2006, xxxvi). However, and this question seems to me as poignantly relevant in 2014 as it was to those who first had to live with the Report in 1839 , how could Durham have been so utterly certain about, in the context of his studied and complete ignorance, throughout his Commission,

11 I am trying here to render as concisely as possible a key passage; a longer excerpt can be found in Lamonde (2000: 267). 
of those like Étienne Parent and Louis-Hyppolite Lafontaine, who represented the camp of moderate Canadian patriotism and support for British constitutionalism? ${ }^{12}$ Lord Durham, preceded by his reputation as a liberal reformer, was greeted with sympathetic anticipation when he disembarked in Québec City in late May 1838. The turning point in the gradual disenchantment towards Lord Durham and his mission was his hiring of Adam Thom, also known in Lower Canada under his pen name of "Camillus," the author of a series of "Anti-Gallic Letters" in the pages of the Montréal Herald (Bindon 1966). Ajzenstat persuasively argues that Durham was a coherent and far-reaching liberal thinker. If his attitude with Lower Canadians of French background - to coin a new category gives us an accurate measure of the man we have to evaluate, fairmindedness (otherwise put, the key humanistic concept of Audi Alteram Partem) was not one of his cherished principles.

Beyond the doctrine of responsible government, has Lord Durham left other structural legacies to the architecture of the Canadian state and to the spirit of Canadian federalism? On this matter, I would like to add a couple of notes to Ajzenstat's remarkably instructive remarks. With regards to responsible government, she is trying to reassess whether Lord Durham wanted to maintain "the crucial powers of control and compliance" in Great Britain at the same time as he was envisaging greater political autonomy for the Canadian colonies (Ajzenstat 2006, xxv). Regarding the division of powers in Canadian federalism, she is attempting to portray him as the forefather of a coherent, overarching principle for such an allocation of responsibilities: the central government would take care of general matters, representatives in the federal Parliament would debate in the language of liberal universalism the issues of concern to all citizens without consideration for their origins, whereas provincial governments would take care of local matters, with legislative representatives embracing the language of human particularities in their debates, paying primary attention to the interests of their citizens as these pertained to their cultural or national origins (Ajzenstat 2006: xxviii-xxviv). On the first matter, I would surmise that the Dominion of Canada in 1867 was indeed in the middle of a three-tiered hierarchical structure. Some crucial powers of control and compliance remained with Westminster (legislative paramountcy, organization of courts and ultimate judiciary arbitration, foreign and defence policies, and overall coordination of the political association). At the same time, the Dominion enjoyed greater autonomy than before while remaining subordinate. Correspondingly, the

12 Lamenting Lord Durham's failure to hear the voices of Lower Canada's French majority representatives is a perennial theme. See Desrosiers $(1937,123)$. See, also, Viau $(1962,163)$. 
Dominion government and Parliament retained substantial powers of control and compliance in precisely the same fields in their relationship with their provincial counterparts. Provinces also claimed greater autonomy while remaining subordinate in key areas. If some validity to this metainterpretation exists, then I would certainly add my voice to Ajzenstat's when she writes that we in Canada have forgotten this scheme as well as Lord Durham's role in its conception. On the second matter, concerning the division of powers, I simply wish to emphasize that this principled distribution's logic is precisely the way in which the project of federal harmony is made sense of for French Canada and Québec around 1867 in two recent, seminal essays written by André Burelle (2005, 433-469) and Eugénie Brouillet (2005, 192-198). At least in Québec, this particular scheme has not been forgotten. But Ajzenstat does not lose everything. Lord Durham's role in its formulation is being completely disregarded.

What conclusion should we have about Lord Durham as a human being and as a thinker? Paradoxically, I think that in the above-mentioned passages of his book on Canada, Ralston Saul has been too harsh on him. The man who arrived here with the promises of spring in 1838, and even more so the one who departed with the bitterly cold rains of November, was in the end too tired, too sick, too engulfed with sadness in his personal life, and considerably weakened as a political animal. In a word, he was thoroughly diminished and thus incapable of moving beyond the prejudices associated with his own complex identity as a doctrinaire liberal politician, an English aristocrat, and a self-conscious British imperialist. On a more theoretical plane, the most thought-provoking evaluation of Lord Durham and his times comes, in my judgment, from Stéphane Dion's pen. According to him, it served Durham's purposes to arrive at the view that it was the French in Canada who espoused the principles and practices of anti-liberalism. This apparently objective sociological assessment allowed him to reconcile his liberal ideas with his geo-political preoccupations. As Dion rhetorically asks himself,

Would Durham have recommended the autonomy of Lower Canada if he had considered sincere the professed liberalism of the patriots? We shall never know, because Durham and Alexis de Tocqueville were thinkers and politicians who formulated their arguments in ways that enabled them never to have to choose between Empire and Liberty (Dion 1990, 75).

So far, I have been mostly preoccupied with what could be called a critical hermeneutics, privileging an understanding of the past for the sake of the past. In the next section I take much greater consideration of the present and of the future. For Lord Durham and his Report remain quite significant for Canada and Québec, and for humankind in general. 


\section{A Critical Hermeneutics for the Present and for the Future}

In a key philosophical essay on the theories and histories of identity in Québec, Jocelyn Maclure (2003, 8-15) has given life to the idea that people in the majority French-speaking province, and first and foremost the intelligentsia, remain obsessed by the spirit of Lord Durham and have not liberated themselves from his shadow. In Maclure's methodological approach, discourses on the matter of collective identity are narrative projects. These narratives contribute substantially to the emergence and consolidation of national communities. The fundamental standard for judging the importance of such narratives is their durable presence in the writings and minds of interpreters. Beyond the contributions that Lord Durham and his Report have made to the nature of the Canadian state and of Canadian federalism, as these have been presented in Ajzenstat's introduction, they are shown by Maclure to have had a strong influence on the dominant ideological doctrine underpinning interpretations of the past in Québec. This all-encompassing feature of intellectual life in Québec is what Maclure characterizes as "melancholy nationalism." We stand here at the meeting point of history, memory, and politics. Discussing the ramifications of melancholy nationalism enables me to start addressing the broader significance of Lord Durham's Report beyond French Canada and Québec, moving towards the idea of an inescapable tension between particularistic and universalistic dimensions of reality. To delineate as precisely as possible the phenomenon of melancholy nationalism, I begin with two quotations: one from Jocelyn Maclure's essay, and one from Jocelyn Létourneau's critical work on the narrative construction of memory and identity in Québec.

There exists in Québec a whole discourse about the fragility, the precariousness, the tragic existence, the fatigue, the modesty, the philistinism, the mediocrity, the immaturity and the indecision of the Québécois people. Those who intone this sombre national chant are drinking from a stream with many confluents. By searching a little and by adopting a certain relationship to the past, one can indeed find in the genesis of Québec society, as well as in its recent history, the fuel for a major depression - or more precisely, a case of collective melancholia. In Freud's terms, melancholia is experienced as a kind of mourning whose sources elude us, which we cannot ascribe to a specific, identifiable loss. That is, melancholia is an elusive, diffuse, latent feeling of grief. From generation to generation, Québec intellectuals and writers have attempted to follow the thread of this melancholia, in the belief that they can work back to the origins of Québec's modern-day ills (Maclure 2003, 20).

This sad view of the past was created by the great French Canadian and Québécois intellectuals, from Garneau to Dumont, loyally and in good faith - 
albeit with varying degrees of modulation, subtlety and complexity [...] For these pioneers of historical consciousness, the inherent fragility of the community required that they carry the country as one holds a child. Thus, for them memory had to be at the beginning of method, misery had to structure the purpose, melancholy had to set the tone, and the text had to nurture memory (Létourneau 2004a, 101-102). ${ }^{13}$

According to the narrative of melancholy nationalism, the vast majority of the people remain fully unconscious of their alienation because they have "internalized in their identity the belittling, traumatizing, even insulting gaze of the other" (Létourneau 2004a, 101). Their imaginary is perpetually haunted by this gaze. The highest literary expression of this perspective of melancholy nationalism can be found in Hubert Aquin's essays and novels. Aquin coined a famous expression, "the cultural fatigue of French Canada," to describe the psychological traits which emerged, at the level of individual and collective consciousness, as consequences of Lord Durham's verdict of permanent minorizing: "selfpunishment, masochism, a sense of unworthiness, 'depression', the lack of enthusiasm and vigour" (Aquin 1977, 88; 1988, 35). ${ }^{14}$ The highest theoretical, philosophical, and historiographical expression in the tradition of melancholy nationalism is the narrative articulated by Dumont in Genèse de la société québécoise. The introjection and appropriation of the Other's degrading contempt has led to the installation of a state of permanent mental colonization in French Canada, carrying with it individual and collective dimensions. According to Dumont, the vicissitudes of this colonization are still at work in contemporary Québec (Maclure 2003, 41-44). While doing research, I could not help but think that Lord Durham symbolically was, and remains to this day, the first significant Other under whose gaze the narrative of melancholy nationalism perpetually unfolds. Consider the following passages near the end of the Report, when Lord Durham vividly recapitulates, for our edification, the gist of his analysis:

I know of no national distinctions marking and continuing a more hopeless inferiority $[\ldots]$ There can hardly be conceived a nationality more destitute of all that can invigorate and elevate a people, than that which is exhibited by the descendants of the French in Lower Canada, owing to their retaining their peculiar language and manners. They are a people with no history, and no literature (Lord Durham's Report in Ajzenstat, 2006).

\footnotetext{
13 In the second chapter of his essay, Maclure critically engages with Létourneau's work and with my own. As he remarks, Létourneau began to focus on the centrality of this melancholical dimension in two important articles. See, Létourneau (1998a; 1998b).

14 I am following here the analysis found in Maclure (2003: 25-28).
} 
The fate of such a destitute nationality in the Americas could only be that of permanent political subordination under the rule of law, or, in Durham's own words, obliteration through the workings of a numerical majority of a loyal English population reinforced by a systematic likeminded immigration (Lord Durham's Report in Ajzenstat, 2006:153). With these passages in mind, it does make sense to view Lord Durham as the true Other of melancholy nationalism. Aside from the works of Aquin and Dumont, I find persuasive illustrations of this connection in essays written by André D'Allemagne (2000, 20) and Jean Bouthillette (1972, 50-51) in the 1960s, the period in Québec history that witnessed the apex of French Canada's collective alienation in the context of global decolonization. ${ }^{15}$ Lord Durham's fate as the historical embodiment of the British or English Other is not restricted to the narratives of melancholy nationalism. I take it that "Anti-Durhamism" plays a fundamental role in a number of ideological statements supporting Québec's aspirations for full political sovereignty. Denis Monière, a political scientist at the Université de Montréal, argues that sovereignty is necessary first and foremost because, since 1867, Canada has fulfilled Lord Durham's vision, chaining French Canadians in Québec to all the social and psychological consequences of a debilitating and paralysing minority political identity (Monière 2001, 138-140). In an attempt to rekindle support for Québec sovereignty, Bouchard makes explicit the links between Lord Durham's heritage, the vocabulary of melancholy nationalism, and the ideal of political independence. Bouchard advocates the need for Québec, as a Francophone and American nation, to be master of its own destiny. He supports the goal of granting greater nobility to the status of Francophone Québécois through the means of redressing nationally and internationally all areas of collective life as well as the will to re-make the identity of French Canadians, to repudiate the heritage of colonialism, and to restore the confidence and self-respect of the Québécois (Bouchard 2006). It should not be denied, according to Jacques Beauchemin, that the goal of sovereignty for Québec is inseparable from a desire to redress the march of history (Beauchemin 2002, 181). From this perspective, achieving sovereignty would be the act of burying, at long last, Lord Durham and his Report. I shall now try to elevate the task of overcoming Lord

15 D'Allemagne makes the connection between the failure of the rebellions, their demoralizing consequences, and the emergence of a deep inferiority complex. Bouthillette describes how French Canadians have become strangers to themselves, how the defeat of Les Patriotes remain their definitive loss, and how this fall into nostalgia has been accompanied by the perfumes of regret and disconsolate pain. Readers should be warned: if you believe that Marx, Hegel, Sartre and Fanon are too abstract and imprecise about alienation, try reading Bouthillette. 
Durham's heritage, and all other similar heritages, to a more universal arena by integrating the insights of French philosopher Paul Ricoeur on the necessary duty to find an equilibrium between remembrance and forgetfulness in the search for a moral way to deal with History.

For individuals as well as for groups, the fall of historical memory into the abyss of melancholy is simply catastrophical. It is nothing short of a terrible disaster. It seems to me that such is the arresting conclusion reached by Ricoeur $(2000,81)$ near the end of his productive and remarkably long life. Whenever any particular community closes itself to its own sufferings, thus becoming "blind and deaf to the sufferings of other communities," history must intervene to criticize, rectify, and admonish the memory of this first community. Through the help of a critical historical hermeneutics, according to Ricoeur, memory meets a certain sense of justice for, as he rhetorically puts it, "What would be a happy memory which would not be, as well, a just memory?" (Ricoeur 2000, 650). The problem for any identity with the triumph of melancholy is a Self that suffers from its own devaluation, from its own condemnation, and from the consequences of its own downgrading, namely depression and anxiety.

Can French Canada and Québec, under the spell of their nationalist and sovereigntist historians, be counted in the category of these communities having followed Ricoeur's unhappy path towards the abyss of melancholy? Such indeed is the argument propounded by Maclure and Létourneau, and such is also Ralston Saul's view when he portrays the insults of Lord Durham in his Report as a wound to be scratched open on a regular basis. There is undeniably an element of truth in this critical assessment. As Jean-Philippe Warren contends, it may be that in its desire to focus on a psychoanalytical approach to the understanding of history, Dumont's generation has nourished and possibly even generated an overlapping sense of anxiety (Warren 1998, 161). Université Laval sociologist Simon Langlois, closely associated to Dumont's school of thought, recognizes that the author of Genèse de la société québécoise had clearly privileged recalling the memory of a certain French Canadian past in the history of Québec, neglecting the faces of diversity in the past and in the present of this society as well the duty of every nation to re-imagine the future in a new light (Langlois 2002, 11). It would however be an over-simplification if one were to conclude that the dominant intellectual characteristic of modern-day Québec is the perpetuation of such a fall into the abyss of melancholy, a fall that would have been inaugurated by Lord Durham's narrative in his Report.

In the social sciences, in literature, as well as in philosophy, the last twenty-five years have been marked by a series of debates on the pluralistic nature of Québec's collective identity and on the need to allow much 
greater space to these plural memories in the reconstruction of Québec's national history. ${ }^{16}$ It is only fair to recognize the leading role played in this enterprise by Gérard Bouchard (1999), who has probably become Québec's pre-eminent historian and intellectual figure since the death of Fernand Dumont in 1997. Echoing Ricoeur's admonitions about the requirements of a happy and just historical memory, Jacques Beauchemin and Daniel Jacques have philosophically argued that in Québec the politics of conquest and of reconquest, must be replaced by a politics of concord - the kind of politics marked by processes of dialogue and reciprocal recognitions, where people steeped in their plural identities argue their way towards reasonable compromises. ${ }^{17}$ In the politics of concord, no vision of the collective future can claim the language of historical normality. Newcomers to such a society must accept that they have climbed aboard a train or that they have joined a movie that started before their arrival (Taylor 2000, 42). However, they should not be over-burdened by the memory of any particular group. In Québec as elsewhere in the world, according to Daniel Jacques, the wounds of the past and the duty to remember should not be the sole guiding principle in matters of political conduct (Jacques 2000, 83).

Maclure, following Freud, described melancholia as a sort of mourning "whose sources elude us." I shall now venture to identify one such possible source of this kind of mourning, thereby re-joining Ajzenstat in her introduction, when she found a fundamental tension at the heart of Lord Durham's Report between universalistic and particularistic dimensions in the unfolding of modernity. What would have happened, in the 1840 s, if Lord Durham recommended - and if British imperial authorities implemented - a regime of dominion-like status or responsible selfgovernment for Lower Canada? Would the French majority have acted despotically, ruling Lower Canada in an unconstrained, intolerant, and absolutist fashion? Or, conversely, would it have inaugurated an era of tolerance, fairness, and pluralism in the history of the modern state, establishing an edifying precedent in a world that was facing, with great difficulty, the conflicting challenges of liberalism and nationalism, and of universalism and particularism, in the middle of the $19^{\text {th }}$ century? There are no guarantees either way, but in the humanities and social sciences we have known since Max Weber $(1965,290-300)$ that it is instructive to think through these options and categories of objective possibility. Lower Canada's past held promises for the future in both directions. Lord Durham, with his

16 Elbaz et al. (1996). See, also, Venne (2000), Maclure and Gagnon (2001), Seymour (1999), and Laforest (1995).

17 See Jacques $(2000,71-76)$ and Beauchemin $(2002,182-183)$. These authors parallel Maclure when he defines dialogue as a process of "reciprocal elucidation." See, Maclure $(2003,15)$. 
Report, buried the optimistic pole of this sphere of objective possibility and I believe this is a major source of mourning that can be discerned in the narrative of melancholy nationalism. Remember Ajzenstat's key question: is universalism implacably hostile to expressions of particularity?

Political philosophers ponder such difficult questions, whereas political communities act upon them. In his own seminal essay, Critique de l'Américanité: Mémoire et démocratie au Québec (Critique of Americanness: Remembrance and Democracy in Québec), published in 2002, Joseph-Yvon Thériault, a sociologist at the Université de Québec à Montréal, argues that this central question, which fascinates Ajzenstat, has always been, since the advent of Lower Canada through the Constitution Act, 1791, the question dominating public debates in the colony, and later on in French Canada and Québec. Thériault calls this interrogation the question of the people, suggesting that the intellectual and political configurations whose development stems from this question can best be understood as the "Durham moment" (Thériault 2002, 286290). This question of the people has always been of a double nature with a universalistic axis, envisaging the nation as a contractual community of individuals with liberal rights, and a particularistic one, emphasizing the broad cultural heritage of the national community. Lord Durham saw the French majority in Lower Canada as overly anchored in a destitute and parochial heritage to be able to lend any hope to the belief that it could elevate itself by its own means to the good of universality. The general spirit of his Report follows a rather Manichean logic: either tradition or modernity, either a nation of individual citizens or a community of heritage. Lord Durham does not integrate into his narrative the fact that ever since the first session of its legislative assembly in 1792, Lower Canada had been struggling, however imperfectly, to find its own proper balance between the good of universality and the good of particularity (Thériault 2002, 294-295). In the end, there is nothing too mysterious about such a tension in philosophy as well as in politics. As Ajzenstat herself remarks, the idea of the ineluctability of this tension is generally accepted in contemporary political theory. ${ }^{18}$

Lord Durham's Report still makes remarkable sense in contemporary Canada and Québec because its reach has extended not only to the nature of the emerging Canadian federal state in 1867, not only in a comprehensive way to the whole intellectual history of French Canada and Québec, whether we prefer to look at it from Maclure's perspective of melancholy nationalism or from Thériault's approach insisting on a "Durham

18 See Ajzenstat (2006, xxvii); see also Taylor, (1996, 357-360) and Kymlicka (2001, 242-253). 
moment." It is also because Durham's reductive and doctrinaire view of the conflict between universality and particularity has exercised great influence on the philosophical make-up of Pierre Elliott Trudeau, Canada's most important $20^{\text {th }}$ century statesman, and the father of our 1982 constitutional revision and the Charter of Rights and Freedoms. Having written about this extensively elsewhere, I do not want to belabour the point (Laforest 1995b, 171-184). I shall only add that regarding Trudeau's own understanding of the struggle between liberal universalism and national particularism in French Canada, major thinkers such as Thériault (2002, $311)$ and Lamonde (2001, 14-15) make an explicit connection between Lord Durham's interpretation and the one propounded by Canada's former Prime Minister. Moreover André Burelle, a friend of Trudeau who worked for him as a speechwriter and a close collaborator during crucial stages of his career, has recently documented the triumph of doctrinaire liberalism in his intellectual evolution, leading to the ultimate expulsion of any meaningful recognition of Québec's difference and of its particularity in the constitution Canada and Québec have inherited from him. ${ }^{19}$ If we are to believe Ajzenstat, there are indeed ways to cope with the tension between universalism and particularism. "Politics is a matter of compromise; even fundamental principles must be bent sometimes - a little - on occasion" (Ajzenstat 2006, xxvii). If we are to believe Burelle, Trudeau thought otherwise with regards to French Canada and Québec. If the connection between Lord Durham and Trudeau holds true, then the spirit of the famous Report not only belongs to our past, but is also rather intimately related to the present and to the future of Canada and Québec.

\section{Conclusion}

Historians should not forget that the task of making history in our liberal and democratic world belongs to citizens. Extrapolating from his own piece of wisdom about this phenomenon, Ricoeur adds that although they only narrate history, these historians remain responsible for what they say, particularly when their work applies to wounded memories (Ricoeur 2006, 323). The existence of a link between a sense of "wounded dignity" and all manifestations of national patriotism in French Canada and Québec is certainly not the exclusive domain of those authors normally associated with melancholy nationalism. How should we deal, here and now, with the wounded dimensions of our collective memory? Quite frankly, I am not an expert on this issue. My best answers, using Lord Durham's Report as an edifying example for us and for people elsewhere, are found in this chapter. More to the point, I believe, with Ricoeur, that

19 Burelle (2005, 68-74, 462-464). 
the memory of those who really suffered in the past must be honoured. Thus, Québec is right to honour the memory of Les Patriotes, particularly the memory of the dozen who died on the scaffolds erected by colonial despotism. Once this is done, I believe it is appropriate to place one's historical wounds in comparative perspective, also paying due respect to the wounds of the other groups and communities with whom one has shared parts of the past and with whom one hopes to share parts of the future. I use a careful expression with regards to the future, because I believe it is open-ended. Constructing an appropriate historical memory for any community should be done without prejudging about the "normal" unfolding of history, I believe this idea of normality is a blatant illusion. It is a fact, as Ralston Saul has argued, that Québec historians of all stripes have paid greater attention to the various conflicts between Francophones and Anglophones than to periods of greater harmony and collaboration. A happy and just memory requires a better balance between these two poles than has so far existed. A happy and just memory requires that, in a complex modern society made of groups and individuals with plural identities, we should pay fair and equal attention to what we have done together, and to one another in the past, and to what we dream of accomplishing in the future. Where does that leave us with Lord Durham and his Report? According to Ajzenstat, Lord Durham's lasting question is the problem of the relationship between universalism and particularism. In his reflections on the very same question, Joseph-Yvon Thériault called it the question of the people in French Canada, and in another passage he called it the question of Québec. The question of Lord Durham is the question of Québec. And this very particular question of Québec carries with it a profoundly universal significance for the world in the $21^{\text {st }}$ century. 



\section{CHAPTER 7 \\ Some Reflections on the Bouchard-Taylor Commission}

The Consultation Commission on Accommodation Practices Related to Cultural Differences was created in February 2007 following a series of incidents that received a great deal of attention in the media and that the Commission's Report itself described as related to increasing identity anxiety between Québec's French-speaking majority and its cultural and religious minorities. The Commission completed the essential task of holding public consultations, which was broadly relayed by the media in the fall of 2007. This was among the two or three most influential of such exercises over the last twenty years in Québec. A few basic statistics are sufficient to establish the Commission's quantitative impact: over 3000 people attended some twenty regional forums, its website received half a million hits, 901 people submitted briefs (the authors of 300 of these briefs were invited to testify). The opportunities to engage in interactive participatory democracy offered by the Commission generated some 120,000 responses on its website. The Commission also held four province-wide forums, established several expert panels, and piloted a number of major research projects. Its overall cost was about $\$ 3.7$ million.

As it had already announced in a consultation document published at the end of the summer of 2007, the Bouchard-Taylor Commission expanded its mandate well beyond the legal dimension of reasonable accommodation, considered as a way of creating flexibility to counteract the discriminatory nature of apparently neutral norms and to face head-on the problems with Québec's social and cultural integration strategy. It thus engaged in a deep analysis of the issues of interculturalism, secularism, immigration, and Québec identity (Québec 2007). In the Commission's words, Québec is a "small nation" that is a cultural minority in North America, and thus it faces, with obvious urgency that will never go away, the challenge of finding ways of living together with different cultures within the same space and the same institutions. Since the question of fair management of diversity is at the heart of public debate in most modern societies, the two co-chairs considered that the Québécois could make the Commission into a strong demonstration of democracy and leave their mark on a major debate. The goals of this vast enterprise in consultative democracy were the following: to inform the Commission on the 
points of view of people from different generations and origins, as well as from different areas of Québec, concerning management of diversity and Québecers shared values; to create a spirit of, and space for, dialogue among people of diverse origins; and, to stimulate reflection on the main communities concerned. Overall, the two co-chairs gave themselves three concrete objectives: to clarify the existing situation, to provide a framework of reference to help those managing institutions, and to communicate their thoughts and make recommendations concerning the future of interethnic relations and the integration strategy most appropriate for Québec society.

If I had to summarize in a single sentence the spirit of the 2008 Bouchard-Taylor Commission Report entitled Building the Future: A Time for Reconciliation, I would choose the following, which is based on remarks made a number of times by the two co-chairs. It is an attempt to show that the concerns of Québec's French-Canadian, Catholic majority heritage are not dissimilar from those of the cultural and religious minorities so that such concerns do not create solitudes closed off to one another. Since, according to the Report, the crisis was fundamentally one of largely false perceptions, blown out of proportion by the media and used by political players for their own immediate and partisan ends, the Bouchard-Taylor Commission remains, in the end, relatively optimistic in so far as Québec has made progress with respect to intercultural and intercommunity reconciliation over the last forty years. The Commission advocates an approach favouring continuity, while acknowledging the need to take strong and immediate action to calm fears on all sides. According to the Report, it is clear that the main share of the conciliatory work has to be done by the majority - French-Canadian Québécois or Québecers of French-Canadian ancestry - since they are still a strong demographic majority (over 78 percent of the population), control institutions, and are able to impose their will in public decision-making. The Report suggests that this majority has a dual status as it is also a minority in Canada and North America. Paradoxically, this majority expresses its collective identity in the form of angst with respect to the minorities' existential anxiety. In their respective works on French Canada and Québec, Gérard Bouchard and Charles Taylor have been exploring this theme for many decades (Bouchard 2003; Taylor 1992a). The following passage from the Report shows clearly that the two co-chairs have always remained aware of the tension inherent in this dual status:

It would certainly be unfair to demand of small minority nations somewhat mistreated by history and constrained to grow by following a perilous course the assurance of imperial nations. In the course of their history they have advanced and withdrawn and experienced surges and doubts. What we have occasionally witnessed over the past two years among certain individuals is 
a nation founded on doubt and withdrawal. However, it would be wrong to generalize and, above all, to lay blame. Instead, it is necessary to refer to our analysis of the very specific coincidence that triggered and sustained the accommodation crisis: situational factors in Montréal inflated by the media and rumours revived among a number of French-Canadian Québecers the anxiety experienced by minorities, already alerted by facets of the international situation.

All in all, it is fairer to rely on a turnaround and a forward-looking movement imbued with good faith and common sense, in a spirit of trust and reconciliation (Québec 2008, 243).

At the very bottom of the crisis, the Commission finds growing fears about identity related to the minority's existential anxiety, the number one constant in Québec's history and of the main demographic group's collective identity that the Commission calls "French-Canadian Québecers." It should be noted that the second major constant in this history is the group's dual status of being the majority in Québec but a minority in North America. Indeed, the first constant may be active or on hold, but it is quite real and remains key. It is a chronic feeling of insecurity to which a loss of ethical markers is added. I will focus on this in greater detail in my own diagnosis of the current state of Québec society. The Commission's Report sees manifestations of this chronic insecurity in the issue at the very foundation of its work: the problem of reasonable accommodation related to integration of immigrants, and in particular fears expressed concerning the ghettoization of Montréal, the resurgence of doubts concerning the French language, and apprehension linked to globalization (Québec 2008, 185-186). The Commission concludes that there certainly have been some excesses, which some have called unreasonable accommodation. However, such cases are extremely limited and we cannot speak of any increase. Yet, these cases crystallized negative perceptions in certain segments of the population, with media and political players fanning the flames (Québec 2008, 186-188). At this stage of its diagnosis, the Commission made an unusual incursion into Canadian politics, and admitted that Supreme Court decisions, the highest tribunal in the country, could have been interpreted as a kind of authoritarian federal trespassing into Québec politics. In large segments of the majority group, the overall picture of this situation has been interpreted as equivalent to rejection or disdain of French-speaking culture, thus awakening certain memories of colonized, humiliated French Canadians. This has led to greater anxiety and identity-related resistance, in which xenophobia and racism may have played roles however marginal and peripheral they may have been. In the section on the origins of the crisis and in another on the fears of the French-Canadian majority, the Commission explores many possible explanations. Let us take a closer look. 
Naturally, the Report frequently returns to the two fundamental constants of minority existential anxiety and the dual majority-minority status in Québec and North America. Use is made of certain discussions in philosophy and the social sciences that have been very critical of national identities and somewhat condescending towards displays of identity. The co-chairs are persuaded that, in the debate over reasonable accommodation, pluralist, interculturalism-oriented Québec has regressed and returned to conservative attitudes. Reactions have at times been disproportionate in relation to the issue of accommodation, involving the resurgence of, and identification with, a certain French Canada that is "diffident" and "mistrustful of the Other" (Québec 2008, 188). Returning to their overall sociological approach, the co-chairs make the realistic observation that identity today remains a fundamental, inevitable social process, which may go astray but can be reformed. In the case of Québec, which will always be a small nation and a cultural minority in North America, the Report insists on the idea that, as a French-speaking place, it will always need a strong identity to calm its fears and be at ease as a peaceful majority. Here we recognize the essential premise of the historical and sociological work that Gérard Bouchard has been doing for over ten years (Bouchard 1999). From what we can tell based on the public interventions by the co-chairs and from the Commission's internal documents (especially the annexes), Bouchard seems to have exercised the greatest intellectual leadership in the Commission's work, and the Report can be seen as nothing less than a new discourse for the Québec nation on the model of Fichte's Reden an die deutsche Nation - in English published as Addresses to the German Nation (Fichte 1922). Some 20 years ago, Léon Dion, a political scientist, explicitly referenced Fichte to launch an appeal for national regeneration (Laforest 1992). Since Léon Dion's death in 1997, which coincided with that of the great sociologist Fernand Dumont (who was himself the veritable Herder of Québec national and cultural identity), Bouchard should deservedly be considered the public intellectual exercising the greatest influence on reflection on Québec culture and national identity (Beauchemin 2002; Létourneau 2000). From this perspective, the Report's interpretative framework, conclusions, and recommendations, in other words the Commission's Report as a whole, is a major intellectual attempt to lead $21^{\text {st }}$ century Québec towards a synthesis between the universal values of liberal democratic modernity, on one side, and the path of its specific identity, on the other. Bouchard, with Taylor's help (I will come back to this in a few paragraphs), is seeking, in Fichte's tradition, a nationalism of educability for contemporary Québec so as to go beyond the famous quarrel between Enlightenment and Romantic thinkers. Alain Renaut summarizes this Fichtean idea of a nationalism of educability in the following way: 
Perhaps it is not in fact impossible to see in Fichte the beginnings of a third perspective on the nation-state, which would be at the centre of a third political philosophy correcting the symmetrical deficiencies of the two preceding ones, opening the national community to a future without completely closing it to its past and culture. Here we would see sketched a concept of the nation obeying yet a different logic, for which nationality would be thought of not in terms of pure and simple loyalty, not pure and simple belonging, but in terms of educability.

However, how should we think about this? Clearly not from the point of view of belonging to a national spirit, for that would risk sinking into the disastrous consequences of Romantic ideas, the inability of thinking of a future for the nation. Fichte in fact saw that the visible sign of inscribing freedom in a culture and tradition consists in the capacity to be educated, in other words, if one prefers, educability about the values of that freedom and that tradition. This explains his insistence on national education as education to the nation (Renaut 1999, 391-392. My translation).

The tension between the universal and the particular, and the idea of calling for national regeneration, can be found in the Report's pages on the concerns of the Québec majority of French-Canadian ancestry. First, the authors speak of the importance of imposing a certain number of fundamental values in school as early as possible such as the primacy of the French language, secularism, and solidarity and equality among men and women. Concerning the condition of the French language, the Commission goes a little beyond its mandate to give a measured assessment of the situation. Some statistics are promising, while others are more worrisome. The Commission acknowledges that, on the linguistic front, Québec will always live in permanent tension and that the situation will require constant vigilance. Concerning traditions and customs, the central location of ethnicity, the Commission shares the opinion of sociologists regarding the extent of the upheavals and unbridled rate of change. The majority cannot blame the worries raised by such transformations on cultural and religious minorities. The Report's most dramatic passages are contained in these pages. The co-chairs write that, for Québec society, it would be preferable to have a memory of plurality rather than a plurality of memories, which could only be a last resort solution. For a memory of plurality to become possible, all Québecers must have access to the meaning that flows from the French-Canadian past by showing what is universal in that singularity. The majority has to make a strong commitment to this undertaking because it has the demographic and institutional strength to do so. Its best assets lie there, rather than on a path that would allow the ascendance of "self-doubt and fear of the Other, the two stumbling blocks of the French-Canadian past" (Québec 2008, 212). On the cultural and 
intercultural fronts, Québec society will always be under strong tension. When we take a comparative perspective, when we see what is happening in other societies living in similar situations, we find that Québec has many advantages. It is an old land of immigration where, overall, newcomers quickly integrate and acquire Canadian citizenship. Since it sees itself as a welcoming place, all political parties consider immigration as a source of wealth necessary for social and economic development. This is in large part because seventy percent of Québec's newcomers are chosen according to their skills and a large percentage of newcomers are middle class. This is especially true of ArabMuslim immigrants, which makes them much less fertile ground for fundamentalism than elsewhere. Finally, on the psychological level, and compared to European countries, Québec faces far fewer problems associated with immigrants from former colonies still suffering the consequences of a painful history. For all of these reasons, the Commission believes that the objective conditions will be met for consolidating a majority-minority dialogue in Québec once the pseudo-crisis of reasonable accommodation has been defused.

According to the Commission, the very future of the Québec nation depends on opening French-Canadian heritage to "the creative, fruitful contribution of the Other" (Québec 2008, 242). It should be noted in passing that the Commission very rarely uses the expression "Québec nation" in the Report, preferring "French-Canadian Québecers," "small nation such as Québec," and "cultural minority." Yet, experts have pointed out that the Commission's exercise in democratic consultation and its Report should be considered as contributions to the Québec national undertaking and to Québec nation-building (Cairns 2008). From this point of view, it is possible that the overall operation made a more positive contribution to national engineering than I consider here, since I concentrate on the relations between Canadian and Québec nation-building, particularly on certain points overlooked by the Commission.

Raising themselves to the status of pedagogues for the Québec nation like Fichte in Germany at the beginning of the $19^{\text {th }}$ century - Bouchard and Taylor invite their fellow citizens to practice four civic virtues: equity, to prevent insistence on differences from obscuring immigrants' real difficulties; receiving and meeting the Other, since the openness to the world of which the Québécois are so proud has to begin with bringing closer together fellow citizens of all origins; moderation and wisdom; and, finally, patience because integration is a process that can take several generations (Québec 2008, 242). Bringing together the three threads of the Commission's work, the Report concludes that in order to truly defuse the reasonable accommodation crisis, we have to: 
- be up to the challenges of integration in a small nation such as Québec, where creative tension and a search for balance between the continuity of French-Canadian heritage, on the one hand, and the imperatives of interculturalism and pluralism, on the other, will always exist;

- more clearly adopt a system of open secularism by balancing four principles: freedom of conscience, equality among individuals, reciprocal independence of church and state, and state neutrality; and,

- strengthen the points of reference and standards that will facilitate better harmonization and integration practices across Québec and, of course, particularly in the Montréal metropolitan area, where the great majority of members of cultural and religious minorities live.

Taylor is universally known for his philosophical anthropology of modernity based on his hermeneutics of modern German thought. In his works, Taylor has tried to reconcile the global leanings of the Enlightenment with the particularistic attractions of Romanticism. He has endeavored to understand the complexity of freedom, equality, and solidarity as equally important normative pillars, building bridges between the analytic and continental philosophical traditions. The quality of his work has led the late Richard Rorty to give him the title of the "New Hegel for Our Times." From the perspective of the Western history of philosophy and Québec and Canada's intellectual history, the encounter between Taylor and Bouchard is a veritable event to which I cannot render justice in this text, beyond a few considerations. First, I draw attention to a passage in the Report's chapter on integration, where we find reference to Alexis de Tocqueville, a key author for Taylor in his discussion of the malaises of modernity. "There can be no society without shared beliefs, without shared ideas, for without shared beliefs and ideas, there can be no communal action, and, finally, without communal action, and the words remain engraved in the memory of every reader of de Tocqueville, there may be people, individuals, but not social body" (Québec 2008, 123). Taylor develops this reference to Tocqueville at greater length in The Malaise of Modernity. Here are some significant excerpts:

Governing a contemporary society is continually recreating a balance between requirements that tend to undercut each other, constantly finding creative solutions as the old equilibria become stultifying. There can never be in the nature of the case a definitive solution (Taylor 1991, 111).

This fragmentation comes about partly through a weakening of the bonds of sympathy, partly in a self-feeding way, through the failure of democratic initiative itself. Because the more fragmented a democratic electorate is in this 
sense, the more they transfer their political energies to promoting their partial groupings $[\ldots]$ and the less it is possible to mobilize democratic majorities around commonly understood programs and policies (Taylor 1991, 113).

Some twenty years ago, at a colloquium on the theme of identity and modernity in Québec, where Alain Touraine and Charles Taylor were the keynote speakers, Taylor tried to reconcile the tension between the universal and the particular in modern identity and specifically Québec identity, without overlooking the issue of possible bases for building bridges between Canadian and Québec national identities. It required understanding that those two identities combine cultural and political dimensions, as most (if not all) modern national identities do. Québec and Canada both aspire to be deliberative units. They need this in order to avoid the third malaise of modernity, which is fragmentation. In order to enable such national undertakings to achieve this objective of unity, great progress would be made if we were to recognize that this can be done while combining elements of convergence and real, strong, recognized differences. In a passage from his 1993 talk, it seems like Taylor is addressing his fellow Québecers as they are engulfed in the reasonable accommodations crisis or in the debate over the Charte des valeurs québécoises:

The Québécois of tomorrow will have to learn to think of their society in a bifocal way, seeing it from different angles depending on the context, and sometimes insisting on convergence as a backdrop to political discussion, but in other circumstances focusing on the conversation among voices that are distinct but mutually invested in one another. Québec's real and growing diversity prevents us from simply adopting the first point of view, while the considerable divide between the majority and the minority keeps us from entrenching ourselves without mediation in the second. We have to learn to combine the two perspectives, in the right proportion, and to develop a complex, multifaceted identity appropriate to our shifting reality (Taylor 1996, 361. My translation).

Regarding the Report's overall balance, I think that major elements in Bouchard's historical and sociological work were given rather more weight than points on which Taylor has tended to focus during his career. The slightly melancholic hermeneutics of the French-Canadian soul, linked with deep disappointment given Québec's failure to achieve its modern destiny through two referendums on sovereignty and coupled with relative indifference to Canada, weighed more heavily than the entirely Tocquevillian importance of common action and integrating Québec's present status into the Canadian political regime, doing justice to both its minority status within Canada and the priority status of French in Québec. I think that the main failing of the Report lies in the fact that it did not give itself the freedom to examine the very real consequences on Québec of contemporary changes in Canadian nation-building. 
Over the last years I often wondered, and still do, about the passionate reactions to the Bouchard-Taylor Commission in Québec public opinion. While the Report rightly criticized the media for exaggerating and portraying reality inaccurately, and while it is unchallengeable that media concentration and convergence gives them a rather exceptional level of penetration in French-speaking Québec society, I do not think that this is where we should place the primary responsibility in this case. That politicians were slow to take action and that some used what the Commission called a perceived crisis also does not explain everything Neither does a degree of clumsiness on the part of the co-chairs, who initially gave the impression that their Report was written before they began and then closed themselves into a kind of silence that opened the way for a certain number of verbal excesses that were luckily without serious consequences. Yet, how can we explain the fact that the Commission helped exacerbate Québec's contemporary identity malaise? I think that the Commission touched one or more raw nerves among the people of Québec at a time when, for many people, there was great worry and strong feelings of insecurity concerning the future of both Québec and their own personal destinies. It all happened after September 11, against the backdrop of a decade marked by security and terrorism problems throughout the world, and at a time when there was a strong Québec presence in a major Canadian military mission in the province of Kandahar in Afghanistan. There were links between that mission and problems internal to Québec (related to the role of religion and gender in society). Indeed, I think that there are five fundamental dilemmas in contemporary Québec that played key roles in the way the Bouchard-Taylor Commission's work was received:

1) The forms of globalization dominated by the English language and culture exacerbate the linguistic insecurity of the Québécois, who are already hyper-aware of their minority status in Canada and North America. The Commission's Report speaks of this, but not enough. The writer Jean Larose expresses this in the following way: "We are told that modern critical thinking, far from emanating from the national spirit, owes everything to mixing, to cultural and linguistic hybridization. Certainly, but do you hear many different languages in the world-class culture of Planet Reebok?" (Larose 1994, 94. My translation)

2) The combined effects of the indebtedness of the state and public institutions and the ageing of the population, which produces a Québec that has trouble modernizing the institutional infrastructure that it inherited from the Quiet Revolution and that is haunted by the perspective of its relative decline in Canada and North 
America and the spectre of economic decline following the model of the frequent crises in Argentina since the 1930s (Dufour 2006).

3) Historically, in French-speaking Québec, it was mainly religion and the apparatus of the Catholic Church that created the social glue. Religion and religiousness have given way to deep non-belief that is in many respects pathological. It is bitter, sacrilegious, disillusioned non-belief (Laurin 2006). Québec lacks institutions producing a social bond or, at least, for those who think I am exaggerating, producing the components of an ethical backbone in the general field of education, particularly with respect to civic education. According to Pierre Vadeboncoeur, in Québec we have liquidated our classics and replaced them with the neoobscurantism of relativist post-modernism, pretending that amorphous licence is the heart of liberty (Vadeboncoeur 2000; Caldwell 2001). This is all hollow but real. It leaves a lot of anomie. The situation can be summarized in a slogan: Québec, a social fabric that is unravelling. For some, those who more or less no longer believe, those whom the Commission called Québecers of FrenchCanadian ancestry, the religion and faith of Others (minorities) is disturbing and poses problems. There is a lot of this in the pseudocrisis of reasonable accommodation. The sociologist Jacques Grand'Maison has summarized this from the perspective of personalist Catholic humanism in the following way: "In this country, it is not the unbearable weight of religious fundamentalism that threatens us most, but the impoverishment of the soul and loss of its depth of meaning, inward regard, motivation, faith and hope" (Grand'Maison 2007, 89-90).

4) The Québec nation, and the modern Québec identity, has a problem of disillusioned historical consciousness, of a historical memory that has difficulty seeing the connection between French-Canadian cultural heritage and modern Québec in terms other than that of a rupture. I have spoken about this before concerning the Québec Historikerstreit in relation to the conflict between the interpretations of Québec's history that Bouchard and Taylor participated in long before their appointments as the Commission's co-chairs. There is a strong vein of melancholy in Québec thought on identity and nationalism. As Paul Ricoeur (2000) pointed out, it is dangerous for both individuals and peoples to sink into the abyss of melancholy, to dwell on their wounds and historical failures. After two referendums in which sovereignists lost, and given the improbability of future success, a number of authors are now discussing moving on from the sovereigntist program to some extent and 
reflecting on the consequences of keeping it among the community's aspirations when there is virtually no possibility of achieving it. Those consequences include the temptation to act in bad faith in Canadian politics, to yield to self-contempt among the younger generations, and to deny reality (Jacques 2007; 2008).

5) Moreover, and I insist on this quite a lot in other chapters of this book, Québec is poorly integrated into Canada, which, in the way its own identity transforms itself, feeds off of the dynamic power of Québec society but does not give Québec adequate legal and political recognition.

The Bouchard-Taylor Commission's Report has certainly shown that Québec has many assets that it can use to manage its internal diversity in a fair and constructive manner. The Commission's examination of the reasonable accommodation saga, a crisis of perceptions rather than a true crisis of inter-community relations, has revealed that there was in the end very little hatred or contempt for the "Other" or "Others" in contemporary Québec. We should rejoice in this, for it is promising for the future. However, since, even in the most sophisticated societies of America and Europe, moderate voices assert the need for identity reference points that can facilitate democratic dialogue and deliberation on how to manage deep, complex diversity, it seems reasonable to me to express some disappointment with the general spirit of the Bouchard-Taylor Commission's Report (Dufour 2006; Goodhart 2006). As Isaiah Berlin (1998) pointed out, rules, principles, and values must yield to one another in specific circumstances. In the midst of all that, we will never be able to hope for better than a precarious balance. If it had more directly and more frankly faced the issue of the unresolved conflict between Canadian and Québec nation-building, which is an unavoidable aspect of the majority-minority issue in contemporary Canada and Québec, the Commission would have had greater credibility when it came to employing the ethical register of dialogue-openness-dignity-self-esteem-trust that is at the heart of what it proposes for tomorrow between Québecers of French-Canadian heritage and Québec's cultural and religious minorities. The Commission's Report is a noble call for compromise, listening, moderation, and patience. It is clear that we find in it the Aristotelian spirit of the golden mean so dear to Taylor. Owing to the quality of its content, and also because of Taylor's international reputation, the Commission's Report will continue to be the subject of abundant discussion in coming years. I think that if the co-chairs had been able to demonstrate greater political courage, their Report would have effectively brought together the two national solitudes of Canada and Québec, in addition to calming the inter-community fears specific to Québec. 
At the heart of Canadian nation-building, as at the heart of Québec nation-building, we find what my colleague from Vancouver, Philip Resnick (2005), calls "metaphysics of doubt." The German language reminds us that the boundary between doubt (Zweifeln) and despair (Verzweifeln) can sometimes be very thin. Taking a broad reconciliatory approach to building the future also requires listening and dialogue, as well as common action uniting the majority and minorities in democratic practices. I think that we can also rightly criticize the Commission for a degree of imbalance between its inter-cultural dialogue approach and what it recommends in terms of political action. In this area, in Québec, in 2014, the foundations for the future remain to be built. 


\section{CHAPTER 8 \\ More Distress than Enchantment The Constitutional Negotiations of November 1981}

The title of this chapter is borrowed from the first volume of the autobiography of Canada's greatest French-Canadian writer linked to the land and the culture of the West. In La détresse et l'enchantement, Gabrielle Roy (1909-1983) delivers a powerfully moving narrative of her childhood in Saint-Boniface and the Winnipeg area in the early $20^{\text {th }}$ century (Roy 1984). Paraphrasing her incomparable prose, I shall argue in this chapter that, seen from Québec and of course without claiming unanimity, the constitutional negotiations of November 1981 and their legal sequel, the Constitution Act, 1982, represent much more distress than enchantment. In the political reality of those years, and in much historical lore ever since, the Province of Québec and its government led by René Lévesque were left in isolation at the end of the day. Québec's National Assembly, the province's legislative branch, withheld its consent and has remained steadfast in its refusal ever since. In Québec and elsewhere in Canada, this story has been told and retold, forming a large chunk of scholarship in many disciplines of the social sciences and humanities.

In this chapter, I wish to provide insightful answers to the three following questions:

1) What were the major causes leading to the constitutional negotiations of 1981?;

2) Which share of responsibility can be attributed to the most important players involved in the negotiations, namely Pierre-Elliott Trudeau (1919-2000), René Lévesque (1922-1987), and the other nine provincial premiers?; and,

3) Thirty years later, is it possible to ascertain the most important political consequences of these negotiations considering that they led to the adoption of the Constitution Act, 1982?

My answers to the first and third questions will be reasonably brief. I hope they will help the readers from the enlightened public to make up their own minds about the significance of these fateful events. My claim to originality here deals with the second question. Much has been written in French and in English about Trudeau's role in the whole constitutional 
business of the 1970s and early 1980s that was, recalling the words of Clarkson and McCall, his "magnificent obsession." However, it is my conviction that Canadian historiography in the English language has almost completely disregarded the insights of André Burelle, a philosopher and federal civil servant who was Trudeau's speechwriter and advisor from 1977 until the months following Patriation. Burelle's books have not been translated and, more regrettably, his original views have been disregarded. I therefore hope to fill that void by using essentially Burelle's analysis to make sense of Trudeau's involvement and behaviour leading up to, and during, the constitutional negotiations of November 1981. In addition, I try to fill a different void that can be felt in the scholarship provided in French by Québecers in the past thirty years. I claim that the role and mistakes of René Lévesque and his Parti Québécois government in the events of 1981 have been thoroughly neglected. In my judgment, the performance of Lévesque and his team during the November 1981 conference in Ottawa was a disaster. I present a series of facts and arguments to substantiate my claim.

In November 2011, I attended a scholarly conference under the auspices of the Centre for Constitutional Studies at the University of Alberta. During the conference, a great deal of attention was accorded to the roles and responsibilities of the nine other premiers beyond Lévesque and Prime Minister Trudeau. I would like to grant a major point and at a later stage to repeat a normative statement. First, as Howard Leeson, Peter Meekison, Peter Lougheed, and Brian Peckford coherently argued at the November 2011 conference, at some point during the 1981 negotiations Trudeau and Lévesque lost the initiative and the nine other premiers dictated the terms that led to the transformation of the constitution. In the end, far from being solely Trudeau's deed, it was also their deed. I thus agree that some further work must be done, from this perspective as well, in rebalancing the scale of responsibilities. I shall examine the normative dimension of this chapter's conclusion. But first, I turn my attention to an examination of the causes that, taken together, brought our top elected politicians to the Ottawa Conference Centre in November 1981.

\section{Causes}

Countries and societies owe a lot in the crafting of their identities and in their political evolution to structural dimensions, to forces that appear distant and anonymous. At times, however, they can be massively changed through the actions of single individuals whose political leadership reaches the level of once-in-a-generation skills or abilities. Thus, I would argue that the first, crucial cause leading to the Patriation Negotiations Conference was Trudeau's re-election in February 1980, 
granting him a fourth mandate at the helm of a majority Liberal government. Fortune provided Trudeau with one more opportunity to bring fruition to his "magnificent obsession" - an opportunity he would not miss. It would however be a mistake to reduce the whole affair to a matter of individual voluntarism.

In Burelle's words, Trudeau brought forward in the early 1980s a dream of Canadian nation building, built around two fundamental dimensions. First, he fostered a form of government-by-judges, through a national Charter reigning supreme over all other provincial charters, reducing the importance of the collective rights of various partners of the federation (and, first and foremost, Québec). He standardized the law and political culture of the country through an idea of symmetrical equality linked to the supremacy of individual rights. Second, he fostered a form of government through "the people of Canada," enabling the federal government to circumvent the old constitution and intrude, however indirectly, in provincial powers in the name of superior national interest (Burelle 1994, 64).

The formidable pressures exercised by Québec on the Canadian political system ever since the advent of the Quiet Revolution acted as motors for change. Discussions surrounding the urgency and necessity of constitutional reform in the 1960 s were, to a substantial extent, provoked by social and political circumstances in Québec (McRoberts 1997, 31). Trudeau's personal decision to enter into the arena of federal politics can also be explained by the same logic. From the 1971 Victoria Charter to the failed constitutional conference of September 1980, Burelle argues in his books that Trudeau made sincere efforts to reconcile his views about contemporary Canada with the 1867 Constitution and with the goals of modern Québec. From 1976 onwards, these aspirations were legitimately expressed by Lévesque and his Parti Québécois government. Their independentist drive, and much of Québec's social dynamism was, however, exhausted by their failure to secure a majority in the sovereigntyassociation referendum held on May 20, 1980. Thus, I argue here that the social and political evolution of Québec represents a second cause leading to the Patriation negotiations of November 1981.

Burelle identifies the third reality in my list of causes. In the 1970s, it dawned on many Canadians, among the political and intellectual elites, that the old Loyalist English-Canadian brand of Canadian nationalism had reached a stalemate. Technically speaking, on one crucial dimension, i.e., the ability to modify substantial elements of the constitution dealing with power sharing between the central and provincial governments, Canada remained a British colony fifty years after the signing of the Statute of Westminster. Canada became officially bilingual in 1969 . The steady and transformative influence of immigration on the country 
was at least partially recognized through the adoption of a multiculturalism policy in 1971. There was thus an appetite out there for a new kind of civic, Canadian nationalism, modernizing the image and the identity of the country at the end of the $20^{\text {th }}$ century (Burelle 2005, 74).

However, the immediate cause of the November 1981 Conference was the late September 1981 decision by the Supreme Court of Canada recognizing the legality of the federal government's unilateral constitutional initiative, but seriously questioning its legitimacy through its formulation of the need for substantial provincial consent. This forced all players, including Trudeau and Lévesque, to the negotiating table one more time.

\section{Assessing the Behaviour of Participants}

Trained as a philosopher, Burelle joined the team of Prime Minister Trudeau's advisors in 1977, also working as his primary speechwriter in French. After nominating their common friend, Gérard Pelletier, as Canadian Ambassador to France, Burelle's voice provided an element of continuity in the evolution of Trudeau's thinking since the early 1950s and his years at Cité Libre. Pelletier, Burelle, and Trudeau were united around the moral philosophy of Christian (Catholic) humanism, owing a lot to European thinkers such as Emmanuel Mounier and Jacques Maritain. Through the works of Denis de Rougemont, this form of Christian humanism inspired some federalist thinkers who played a key role in Europe's intellectual reconstruction after 1945. This doctrine is summarized as personnalisme communautaire (communitarian personalism), giving moral primacy to human beings as persons, without neglecting the communities that are essential to the full development of their human personality. As a political philosophy of federalism, communitarian personalism, as interpreted by Burelle, amounts to a combination of four principles: equivalence of treatment rather than symmetrical equality for persons and groups; subsidiarity as a principle for the division of powers; non-subordination as a principle for the division of sovereignty between levels of government; and, finally, co-decision as a principle for the management of interdependence between the partners of the federation (Burelle 2005, 44). Burelle's insight shows that, until the Constitutional Conference of September 1980, this doctrine occupied a central place in Trudeau's thought, competing with the more abstract, doctrinaire brand of liberal individualism, and with anti-nationalist and anti-communitarian leanings, that Trudeau took from his years of training in the United Kingdom and United States. Trudeau's trajectory is often presented as showing the edifying triumph of liberal reason over nationalist passion. On this matter, Burelle invites us to think more carefully. According to him, there was indeed a struggle between reason and passion in Trudeau's 
mind, but it was a different and more complicated one. Having worked for Trudeau, and studied the evolution of his thinking throughout the years, Burelle concludes that Trudeau was passionately liberal-individualistic and therefore it was his rational side that restrained this by bringing into the equation the nuances of communitarian personalism (Burelle 2005, 68). Thus, Trudeau's own mind was the theater for a massive spiritual struggle between principles. Burelle is able to show in his book, through a careful list of quotes from the 1950s to the late 1970s, that Trudeau was able to maintain equilibrium in his thinking between these principles until September 1980. Moreover according to Burelle, there was some substantial room in this spiritual equilibrium for the distinctiveness and constitutional requirements of Québec.

For instance, as late as the Constitutional Conference of September 1980, Trudeau was willing to propose a preamble for the new constitution that would define Canada as being first and foremost a federation, protecting individual and collective rights (including those of Aboriginal peoples) and recognizing the distinct character of Québec society with its French-speaking majority. Moreover, pretty much in line with such major documents of renewed federalism at the time like the Pépin-Robarts Report and the Livre Beige of Claude Ryan's Liberals, Trudeau was also prepared to make room for Québec's distinctiveness in federal institutions including granting Québec a right to veto future amendments. As late as September 1980, Trudeau was also prepared to include in the Constitution a more coherent and cooperative structure for intergovernmental collaboration and he was willing to consider forms of asymmetry on matters such as culture, language, immigration, and telecommunications (Burelle 2005, 63). It is only after the failure of the September 1980 constitutional conference that Trudeau abandoned these elements and, more fundamentally, that a break of equilibrium emerged in his own mind between the various sources and principles fighting for primacy in his very soul. What were the sources and the reasons for this change? It is here, I believe, that Burelle explores uncharted waters in intellectual history. Before summarizing his explanations, one should pay careful attention to his lament:

Why such absence of any recognition of the distinct character of Québec society in the Constitution Act, 1982? How to justify the enshrinement of a charter of rights limiting, without the consent of the National Assembly, the sovereign powers of Québec on matters of language? How to explain the abandonment by Mr. Trudeau of the requirement to extend to Ontario and to New Brunswick the obligations imposed on Québec by section 133 of the 1867 constitution, in contradiction with the federal proposal of September 1980? How to explain the decision to withdraw the offer made to Québec to decentralize powers in the fields of language, culture, and telecommunications, while maintaining similar decentralizing offers to the Western provinces in 
matters relating to natural resources? Why in the end did Mr. Trudeau accept a constitutional amending formula depriving Québec of its historic veto after having struggled so hard and for so long for the Victoria formula of regional vetoes? (Burelle 2005, 66. My translation)

In his search for explanations, Burelle seeks to distinguish between, on the one hand, a superficial and immediate pretext and, on the other hand, a wide array of personal, intellectual, and political reasons. According to him, the failure of the September 1980 Constitutional Conference offered Trudeau a pretext to change his mind and adopt a tougher position towards provinces and particularly towards Québec, and ultimately to attempt a unilateral approach. The Québec delegation at that conference played a key role in the formulation of a vastly decentralizing inter-provincial agreement known as the Chateau Laurier consensus. Four months after the referendum on sovereignty-association, Trudeau decoded from this document a clear strategy, on the part of the Québec delegation led by Lévesque and Morin, to prevent substantial constitutional reform at all costs (Burelle 2005, 65). And it is in this context, according to Burelle, that Trudeau committed himself to a Jacobine, liberal-individualistic refounding of the Canadian nation. In the ensuing pages of his book, Burelle seeks to identify and analyse the more complex causes for Trudeau's change of mind. I enumerate here, and discuss briefly, these various factors in the same order that Burelle presented them.

\section{A. Trudeau's Visceral Individualism and Anti-nationalism}

Had he been a Jew, according to his friend Gérard Pelletier, Trudeau would have much preferred leading a life of personal excellence in exile in New York City, rather than living in Israel and witnessing the necessary interventions of a nation-state on behalf of the Jewish people (Burelle 2005, 70). There were some dark sides to French-Canadian nationalism and to Trudeau's own personal trajectory in the 1930s and 1940s. ${ }^{1}$ According to Burelle, between 1948 and 1950, Trudeau went through a kind of passionate and very personal epiphany and self-transformation, moving beyond his own milieu to espouse a form of communitarian uprootedness (déracinement communautaire, in French). However, until September 1980, his more rational side preserved the idea of equilibrium between the requirements of the individual and those of the community.

For this, see Nemni and Nemni (2006) and English (2006). 


\section{B. The Crisis of the Old Loyalist Nationalism in English-speaking Canada}

As I have shown in an earlier section of this chapter dealing with the causes of the Patriation Conference of November 1981, English-speaking Canada was more than ready in the early 1980s for a self-redefinition as a multicultural and bilingual nation. This created political space for Trudeau's new resolve to nation-build in late September-early October 1980. Burelle laments, on this issue, Trudeau's unwillingness in the last years of his life to recognize the emergence in Québec of an authentic civic nationalism open to the values of pluralistic modernity (Burelle 2005, 76).

\section{Change of the Palace Guard in Ottawa}

For many years, Trudeau's dogmatic stance against (Québec) nationalism was balanced by the presence of figures such as Gérard Pelletier and Jean Marchand at his side. However, in the early 1980s, they had disappeared from the scene and the key players around Trudeau were Jim Coutts and Tom Axworthy in the Prime Minister's Office, Michael Pitfield at the Privy Council Office (replacing Gordon Robertson), and Michael Kirby in charge of the Bureau for Federal-Provincial Relations. If for quite some time there were two sides to Trudeau's thought, as Burelle contends, there was radical imbalance between these sides in the early 1980 s.

\section{The Loneliness of Power}

Critical of Trudeau's actions on the constitutional front, Burelle has always remained faithful to the intellectual friendship he shared with him and Pelletier. Having worked closely with Trudeau over many years, Burelle is fully aware of how tough it was for Trudeau to maintain some balance between the principles and moral sources in play. In the end, the Prime Minister was alone in taking crucial decisions. Trudeau removed Burelle from close contact with the constitutional file in the summer of 1980, much as he had done with Gordon Robertson, because he did not want to be paralysed by Burelle's troubling memos appealing to the part of his thought that he had just chosen to discard from his unilateral strategy (Burelle 2005, 81-82).

\section{E. Electoral Contingencies and the Hubris of the Resurrected}

I combine here two aspects mentioned by Burelle. In the summer of 1979, Trudeau looked like a spent force in Canadian politics. He had lost the federal election to Joe Clark and the Conservatives, had announced 
his retirement from politics, and analysts commented that, despite his achievements, he had failed on the two issues that mattered most to him reforming and patriating the constitution and fighting Québec separatism. However, fortune was on Trudeau's side. The Clark government soon fell after losing a confidence vote on the budget in the House of Commons, presenting Trudeau with an opportunity to stay on and lead the Liberals to a majority government in the federal elections of February 1980. Thereafter, he would fight even more implacably than before, imbued with a renewed sense of historic mission (Burelle 2005, 88).

\section{F. The Inevitable Polarization of Political Confrontation}

According to Burelle, and many other observers, Trudeau was always at his very best in a highly polarized political contest. The change of strategy starting in early October 1980 perfectly suited this aspect of his personality. Patriating the constitution thus became the opportunity to elevate Ottawa as a champion of individual rights against power-hungry provinces, and to win decisively not only against Lévesque and the separatists, but also against all forms of Québec nationalism. Combining both dimensions, as we shall see again in the conclusion of this chapter, would be the elevation of language rights to the status of fundamental individual rights removed from the bite of the notwithstanding clause (Burelle 2005, 85).

\section{G. The Good Fortune to Negotiate with the "Vanquished" and the Need to Avoid a Confrontation with Ryan}

I also combine here two dimensions discussed separately by Burelle. In the Québec referendum of May 20, 1980, René Lévesque had lost, whereas Claude Ryan, leader of the provincial Liberals and president of the "No" Committee, had clearly won. As a ranking federalist in Québec, Ryan appeared after the referendum as the province's rising political force, and for a while it looked as if Trudeau would have had to negotiate constitutional reform with him as his counterpart. Trudeau and Ryan knew each other since the 1950s. Each respected the other's intellectual force, but they never established a political rapport. Both were champions of individual rights, but they entertained substantial differences in their conceptions of nationalism and federalism. According to Burelle, Trudeau knew that negotiating with Ryan would have been extremely tough. Luckily, once more for Trudeau, Ryan lost the Québec elections of April 13, 1981, and Trudeau was able to negotiate with his old nemesis, René Lévesque, whom he had, at least figuratively speaking, vanquished in the 1980 referendum. Burelle claims that Ryan made a mistake when he chose not to denounce the radical illegitimacy of the Lévesque 
government to negotiate renewed federalism in the immediate aftermath of the referendum.

Burelle helps us to understand the causes leading to the Patriation Conference and to the new constitution, and he also sheds considerable light on Trudeau's role leading to the overall result. In the end, Burelle's most important contribution is probably a much deeper understanding than currently found in the literature about Trudeau's behaviour and motivations. Politically resurrected in February 1980 and liberated spiritually from the need to integrate the complexities of communitarian personalism after September 1980, Trudeau launched a new constitutional offensive aimed at founding anew the Canadian nation, and thereby settling his score with Lévesque, his government, and Québec nationalism as a whole.

In the second part of this section, I wish to navigate more uncharted waters, trying to explain, at least in some detail, the role and more precisely the mistakes of René Lévesque and of his government. A word of caution for readers: to the best of my knowledge, more than thirty years after these events, no single study - whether a book-length monograph, chapter, or article, in either English or French - has had the primary objective of tackling this crucial task. Sure, Claude Morin, Lévesque's Minister of Intergovernmental Affairs and right-hand man at the time of the Conference, has written books touching on the issue (Morin 1988, 1994). However, his main objective was to attack Trudeau and the federal government, and to engage in critical dialogue with his counterparts from elsewhere in Canada (for instance, Roy Romanow) to underline and bemoan the fact that they had abandoned Lévesque, his government, and Québec. I believe it is high time for a lucid analysis of Québec's performance in 1981-1982. ${ }^{2}$

My narrative starts the morning after the referendum of May 20, 1980. Lévesque and his government had just been resoundingly defeated in the referendum they had sponsored on sovereignty-association. In a previous chapter of this book, I made an analogy between the referendums of 1980-1981 and the rebellions of 1837-1838, calling the latter the failed rebellions of the imperial age, and the former the failed rebellions of the democratic age. In the democratic era, as in the imperial one, leaders of a national minority who embark upon a major initiative to reform or break out of the state system, and who happen to lose in the endeavour, have to deal with the strategic fact that they will be weaker if they fail. Losing carries negative consequences. Reading the historical documents the analyses, the memoirs, and the autobiographies by Québec political

\footnotetext{
For a partial attempt at this endeavor, see Dion (1995, 42-43).
} 
leaders at the time - one is struck by the air of negativity and pessimism that looms over their heads during the whole period leading to the Patriation Conference and to the promulgation of the new Constitution. They never recovered from the political defeat of May 20, 1980. As we shall see, they had some good days and made some tactical gains in the aftermath of the referendum, but at most key moments their behaviour was mostly characterized by improvisation. Referendums are high-risk affairs. They should be held, by leaders or people yielding to an ethics of responsibility, only when its promoters are quasi-certain of winning them. Lévesque and his team had no such certainty in 1979-1980. Nevertheless, they went ahead. The failed referendum diminished Lévesque, the stature of his government, and, in the end, the place of Québec in Canada.

Pierre Godin, René Lévesque's biographer, coherently establishes in his narrative of the days and weeks following the referendum that Lévesque and his government had not carefully developed any strategy for the eventuality of a referendum loss. Lévesque's first meetings with his top advisors, cabinet, and caucus show clearly that they simply had no idea at the time about their next steps. They were manifestly on the defensive, reacting to the initiatives of Trudeau and of his Minister, Jean Chrétien. Very early on, Lévesque and his colleagues decided that they would continue to govern Québec until the end of their mandate, and that their key priority would be to defeat Claude Ryan and the Liberals in the Québec elections that ended up taking place on April 13, 1981. Between 1978, the year Ryan became Liberal leader, and late September 1981, the time of the Supreme Court Patriation Reference, no formal encounter took place between Lévesque and Ryan. These two men knew each other since the early days of the Quiet Revolution. In the 1960s, as editor of Le Devoir, Ryan was respected in Québec and throughout Canada as a careful thinker and éminence grise of renewed federalism. In 1979, Ryan's Québec Liberal Party had published its Livre Beige, one of the key documents of renewed federalism in the months leading up to the May 1980 referendum. It was known to everyone that Ryan and Trudeau did not see eye to eye on the issue of reforming the Canadian constitution. Lévesque could have made much greater use of Ryan, his advice, and his legitimacy as a federalist leader and thinker in the negotiations leading up to the Patriation Conference. Quite naturally, there was some acrimony between these men who fought on the battlefields of the referendum and a tough electoral campaign in the spring of 1981. Until the last minute, even during the Patriation Conference, Ryan made efforts to get in touch with Lévesque, who did not even return his phone call (Godin 2005, 152). Ignoring Ryan throughout the process was Lévesque's first major mistake. 
The second major mistake relates to the struggle between Lévesque and Ryan during the Québec elections of April 1981. Barely three days after the elections, Québec chose to endorse a major proposal by the inter-provincial front known as the Gang of Eight, which aimed to derail the federal government's unilateral strategy announced by Trudeau in the House of Commons on October 2, 1980. On April 16, 1981, the Lévesque Government abandoned Québec's historic constitutional veto (a veto that many observers from outside Québec, including Donald Smiley, thought that it had at the time) for an amending formula that required, for most changes, the consent of two thirds of the provinces, enriched by an optingout clause with fiscal compensation. The Lévesque Government could have clearly explained that their agreement would remain valid only if, in the end, Québec deemed acceptable a full constitutional reform package, explicitly retaining its historic veto if such an agreement did not materialize. During the electoral campaign in Québec, the task of overseeing the constitutional file rested exclusively on Claude Morin, the Minister in charge, and Robert Normand, his Deputy Minister. Lévesque and the cabinet, overburdened by the campaign and much of the supporting bureaucratic team, were completely left out (Tremblay 2006, 262-263). The decision to abandon the veto was thus made by three people, including Lévesque. I believe it is fair to argue that they acted precipitously. I now turn to Québec's behaviour on the judiciary front of the constitutional struggles.

After Trudeau announced his desire to act unilaterally, Québec joined two provinces (Manitoba and Newfoundland) in moving the issue to their respective Courts of Appeal. Decisions on these References came out in the spring of 1981, with the Québec government losing in front of its own Court, by a margin of four to one, while Trudeau's unilateralism suffered a crucial defeat in Newfoundland, where it lost by a margin of three to two. From there the issue moved to the Supreme Court of Canada, with Québec joining the opposing provinces in pleading procedures heard by the Court. The Supreme Court rendered its judgment on September 28, 1981. In late December and early January 1982, after the Patriation Conference, Québec's government went once more to its own Court of Appeal, on the issue of the existence of a veto right for the province. Lévesque's government was once more defeated in a judgment rendered in early May 1982. Finally, the Supreme Court of Canada confirmed the decision of Québec's Court of Appeal in early December 1982. In the fall of 1980, for reasons that have remained unknown until now, Lévesque and Morin changed their team of constitutional lawyers, led by Laval constitutional expert Henri Brun, replacing him with former Supreme Court Justice Yves Pratte. Although an experienced lawyer and judge, Pratte did not have much time to prepare Québec's brief in the Patriation Reference. 
As will become clear in a moment, the problem on the judiciary front is not what Québec pleaded - traditional arguments about duality and founding peoples, and historical precedents in 1964 and 1971 that supported the idea that Québec indeed had a veto right - but rather what it did not plead. Second, after the Supreme Court rendered its first decision in September 1981 in the Patriation Reference, Québec decided, probably out of solidarity with the Gang of Eight, not to return in a Reference to its own Court of Appeal about the existence of a specific right of veto for the province. When it chose to do so, it was more than two months after the Patriation Conference, when preparations were already under way for promulgation by the Queen in Ottawa in early April. All in all, on the judiciary front, Québec was indecisive throughout.

Which key argument was completely ignored by Québec's lawyers? As Donald Smiley wrote at the time of Patriation - thus demonstrating that the argument was indeed legally and politically available in the early 1980s - the Constitution Act, 1867, known as the British North America Act, 1867 prior to Patriation, contained a clause allowing federal authorities to homogenize or standardize the legal space of common law provinces on matters of property and civil rights, provided that these provinces would give their explicit legislative consent. As I argue more fully elsewhere in this book, there was no mention of Québec in this article, section 94 of the constitution. But considering that Québec, known as Canada East in the 1860s, had just codified its civil law, and taking into account that George-Étienne Cartier viewed section 92(13) as a triumph for Québec autonomy because it secured provincial control over property and civil rights, it was clear to Smiley in the early 1980s, as it should have been crystal clear to the Lévesque's government and its constitutional lawyers, that the overall meaning of section 94 was a recognition of Québec's particularity (Smiley 1983, 77). In 1981-1982, Québec should have argued that, in the very least, a constitutional reform touching provincial powers in the field of property and civil rights (something recognized by every court in the key judgments of the times) required its explicit legislative consent (see, also, LaSelva 1995, 62-63).

Although there is substantial severity in my judgment, I am far from suggesting that the Québec government did everything wrong between the spring of 1980 and the Patriation Conference of November 1981. First, Québec undeniably played a positive and key role in the Gang of Eight, the inter-provincial alliance opposed to Trudeau's unilateralism. For a while, particularly after the September 1980 Constitutional Conference that proved disastrous for the Trudeau government, many provincial premiers looked more comfortable with Lévesque than with Trudeau. Aside from the issue of the amending formula and the matter 
of a veto right, as previously discussed, the Lévesque government managed to act both for its own interests and for the sake of the alliance until the Patriation Conference. Moreover, as many analysts have recognized, the Québec Delegation in London, led by Gilles Loiselle, played a crucial role in the manoeuvres of the provincial alliance wishing to inform British authorities about their arguments, which ultimately prevailed in the Report of the Parliamentary Committee (British North America acts: the role of parliament: first report from the Foreign Affairs Committee) led by Anthony Kershaw submitted in early February 1981 (Clarkson and McCall 1990, 320).

I have argued that there was much improvisation on the part of the Québec government at the beginning of the process that led to the Patriation Conference in November 1981 during the immediate aftermath of the May 1980 referendum. The same remark applies to the behaviour of the Québec delegation during the Conference itself. Québec arrived in Ottawa with a rather weak team, featuring, beyond Lévesque, Morin and Normand, two experienced people in charge of the file since the referendum. More surprisingly, two other Ministers completed the delegation: Marc-André Bédard, who was there in his capacity as the Minister of Justice, and Claude Charron, at the time the Parliamentary Leader of the Government and who was included mostly because Lévesque liked his dynamism and appreciated his presence at such meetings (Godin 2005, 152). Senior Ministers of the Québec government, such as Jacques Parizeau, Bernard Landry, and Pierre-Marc Johnson (all of whom would later become Premiers of Québec) were left out. Amazingly, Parizeau invited himself to the Conference, was brought in for a day, but returned home totally distressed by the chaotic atmosphere surrounding the Québec delegation (Godin 2005, 159). ${ }^{3}$ All observers, including those like Martine Tremblay who was quite sympathetic and loyal to the Premier, note that during the conference Lévesque often looked tired, confused, enraged at times, and even depressed.

The greatest and most fateful instance of improvisation took place late in the morning of November 4 when Trudeau publically proposed to Lévesque to change the paradigm or model for the whole constitutional business, suggesting that the matter should be submitted to the people in a referendum. Amazingly, without consulting anybody, Lévesque seemed to indicate that this was a very good idea and that he was willing to explore this in greater detail with Trudeau. Notwithstanding all the other projects that were being discussed in the heated atmosphere of the Conference, involving among others the federal delegation (including

For a dissident view on this, see Tremblay (2006: 268-269). 
Jean Chrétien) and provincial delegations from Ontario, Saskatchewan, and British Columbia, this amounted to an acknowledgment, on the part of Lévesque, that he was willing to go his own way beyond the agreements between the members of the Gang of Eight. When the Conference reconvened that afternoon and Trudeau rendered public the details for his prospective referendum, it soon became clear to Lévesque and the Québec delegation that this new deal or project was unpalatable to them. Apparently, the day ended with an impasse and with the members of the Québec delegation retiring to their hotel on the other side of the Ottawa River where they would spend the night with no communications whatsoever with their allies or with their adversaries at the conference, except a short phone call from Bill Bennett to tell them that breakfast would take place half an hour later the next morning. The rest is history. And the rest, as Howard Leeson explains in his useful book, involves the nine other premiers taking matters into their own hands, seizing the initiative which had belonged for so long to Trudeau, or Lévesque, or both, and agreeing in the end on a constitutional package that suited their interests (Leeson 2011, 81). A compromise was found with Trudeau on the night of November 4, but a compromise was never reached with Lévesque and his government. Thirty years later, no such compromise has been arrived at with a Québec government, and none appears to be looming. For Lévesque and his delegation, the Patriation Conference turned out to be a catastrophe of the greatest magnitude. As a political actor, and possibly as a human being, Lévesque never recovered.

Weakened by his referendum defeat and disheartened by the disaster of the Patriation Conference, Lévesque would learn, a couple of weeks after the Conference, that his main constitutional advisor, Claude Morin, had accepted money and acted as an RCMP informant before and after the election of the Parti Québécois government in November 1976. Morin had twenty-nine meetings with RCMP officials between 1975 and late 1977 (Godin 2001, 460, 612). After that, Lévesque was indeed a broken man, and this explains why he could never convince himself to try to use the democratic and referendum card to prevent the Patriation of the Canadian Constitution without Québec's consent. Trudeau had his own reasons not to present "the people's package" to the Canadian people, but they do not need to be discussed here. Insofar as Lévesque is concerned, he appears to have been simply too discouraged to even consider this option.

Without Trudeau's forceful actions and willpower, there certainly would have been no Patriation Conference and no meaningful constitutional reform for Canada in 1982. However, contrary to hegemonic interpretations in English-speaking Canada, Trudeau's behaviour on 
constitutional affairs, and particularly his approach towards Québec, showed clear contradictions. Burelle sheds much needed light on some of Trudeau's complex motivations. The nine English-speaking premiers were key constitution-makers, although they only seized the initiative very late in the process, on November 4, 1981. In the end, they were not just bystanders. They jointly shared responsibility with Trudeau for imposing a constitutional reform on Québec. Upon closer examination, it is also fair to say, at least in my judgment, that Lévesque and his government must also be held responsible for Québec's constitutional isolation. I now turn to an examination of the consequences of the Patriation Conference of November 1981.

\section{Consequences}

The constitutional negotiations of November 1981 led to the adoption of the Constitution Act, 1982 in the following spring. I wish to explore here, however briefly, six consequences of these fateful events.

(1) Judicialization of Canadian politics. In the equilibrium between the executive, legislative, and judiciary branches of government, the 1981 negotiations led to a constitutional reform that considerably reinforced the role of tribunals, and particularly the role of the Supreme Court, in our system. The Supreme Court has become much more than the umpire of federalism. It sees itself as our primary constitutional guardian, steward of the actions of governments, and protector of the rights of citizens. Kelly and Manfredi see four major factors at work here: "constitutional provisions explicitly authorizing judicial participation in public policy; judicial approaches to governing with the Charter; changing approaches to governance by parliamentary actors; and finally, greater recourse to the courts by citizens seeking policy changes denied by parliamentary politics" (Kelly and Manfredi 2009, 6).

(2) Securing a strong constitutional anchor for the rights of Aboriginal peoples. Paradoxically, Québec's societal and political energy fuelled constitutional reform in the late 1970 s, but it came out of it with reduced powers and no constitutional provision explicitly targeted to its requirements. Aboriginal peoples, on the other hand, were left out of the processes of constitutional dialogue, but came out of the business of 1981-1982 with a strong legal anchor through section 25 of the Canadian Charter of Rights and Freedoms and section 35 of the Constitution Act, 1982.

(3) Transforming Canadian national identity and reinforcing the allegiance of citizens to the federal government and the Canadian state. This consequence relates to André Burelle's work and his analysis of Trudeau's political and intellectual trajectories. Burelle believes that the reforms of 1981-1982 amounted to the abandonment of the social contract flowing from 
the 1867 Constitution and its understanding of Canada as a multinational polity (Burelle 2005, 440-441). The following excerpts by Alan Cairns and Sujit Choudhry provide further ammunition for Burelle's interpretation:

Put differently, the Charter was a nationalizing, Canadianizing constitutional instrument intended to shape the psyches and identities of Canadians. The Charter, accordingly, was a constitutional weapon analogous to disallowance, with its objective of constraining the diversities that federalism both reflects and sustains. (Cairns 2011, 370).

The Charter relies on both the regulative and constitutive conceptions of a bill of rights to serve as an instrument of nation building. In regulatory terms, the Charter imposes legal restraints on minority nation building by Québec, through the rights to inter-provincial mobility and to minority language education for children [...] However, the Charter was also intended to function constitutively as the germ of pan-Canadian constitutional patriotism. (Choudhry 2009, 239, 241).

(4) Greater Québec alienation. In recent years, many political columnists, including Chantal Hébert and Jeffrey Simpson, have frequently commented about the gradual estrangement of Québec and Québecers from Canadian political life. This idea is in the air, but it should be studied more empirically. In the federal elections of May 2, 2011, Québecers abandoned the Bloc Québécois and voted en masse for Jack Layton's New Democratic Party. I believe that the two global societies of Frenchspeaking Québec and English-speaking Canada are more indifferent to one another than thirty years ago, but I recognize that this should be verified beyond the assertions of media pundits and beyond my own academic perceptions.

(5) Greater hardship for constitutional change. The 1981-1982 saga left us with a complex amending formula, rendered even more rigid by the idea of regional vetoes introduced by the Chrétien government, by some requirements for provincial referendums in order to ratify reforms, and by the need to secure the involvement of all concerned including Aboriginal peoples stemming from the 1998 Supreme Court Reference re Secession of Québec. Our Constitution remains amendable (for instance, Ottawa and Québec agreed on a modification to section 93 of the Constitution Act, 1867), but it is legally and politically now extraordinarily difficult to secure and ratify changes.

(6) Reduction of the importance of federalism within our political regime. Finally, it can be argued that the principle of federalism - the idea of equilibrium between self-rule for provincial communities and shared rule across Canada, granting substantial policy autonomy to provinces while preserving solidarity and interdependence - has been weakened by the 1981-1982 reforms. The thrust of the constitutional reform was 
deliberately (see my third consequence) centralizing and standardizing. On the issue of language rights, Burelle has always believed that justice and fairness belong to an ethics of equivalence of treatment rather than to an ethics of symmetrical or standardized treatment (Burelle 2005, 446). José Woehrling has also explored the consequences of this for Québec:

In so far as rights protection through a constitutional instrument is an antimajority mechanism, it limits the political autonomy of minorities that control territorial entities. A minority controlling such an entity sees its political power restricted for the benefits of its own minorities. The most problematic situation occurs when 'the minority within the minority' is part of the majority at the national level, as is the case for minority English speakers in Québec who are part of the English-speaking majority in Canada. The majority at the national level can then give in to the temptation to use its power to impose on its minority compliance with excessive guarantees benefiting 'the minority within the minority' (Woehrling 2009, 243-244).

\section{Conclusion}

In the end, in the fall of 1981, the English-speaking Canadian majority abused its powers. This is based on the actions of its leaders both at the federal and provincial levels, through the institutions of executive federalism, the lack of a referendum or elections to give democratic legitimacy to the so-called people's package, and no legislative debates or ratifications in all but one (Alberta) of the provincial legislatures. It has proven to be an operation that has, in many ways, challenged the understanding of Canada as a fundamentally federal community. The primary responsibility for this belongs to Prime Minister Trudeau but also, in truth, to all the premiers involved. This is the normative point that I alluded to in this chapter's introduction. The nine premiers knew there was a risk involved in going without Québec, but individually and collectively they were and remain to this day, or so it seems, willing to accept it. Smiley considered the whole affair a dangerous deed, for the following reason:

In my view, the first-line protection of the rights of the francophone community of Québec is and has been since Confederation among the powers of the Legislature and government of that province, and on this basis Canadian constitutional convention dictates that these powers should not be restricted without Québec's assent (Smiley 1983, 86).

Nevertheless, as I have shown, there were mitigating circumstances. First, Trudeau came from Québec, which meant his voice carried huge legitimacy, and in the vote that took place in the House of Commons 73 out of 75 of Québec's Members of Parliament voted in favour of Patriation. Technically speaking, it did not authorize them to reduce without their consent the powers of their counterparts in Québec's National Assembly, 
but for many people in the public this can be seen as an obscure normative point, particularly when the federal element in the political culture of the land carries less traction than before. Second, Québec authorities played very poorly. Lévesque and people associated with his government must accept a greater share of the responsibility than has been admitted up to now. Third, in the political and symbolical circumstances of the time, many people sensed that, in the late 1970s, Patriation offered Canada a glorious opportunity to found anew its idea of nationhood. Fourth, we should not forget that the Patriation experiment was draped in the language of rights, the dominant idiom of moral and political philosophy in the world after 1945. In their seminal study, Clarkson and McCall captured this aspect very clearly, also targeting its major flaw as seen by many in Québec:

The notion of an entrenched charter of rights and freedoms would appeal to the legal establishment and civil libertarians among the country's liberalminded intellectual elite [...] With all these favorable aspects of the package diverting attention, the 'constitutionalization' of the official languages law and the entrenchment of minority-language education rights would be camouflaged. While this canny move to outwit Lévesque and the separatists was well understood in Québec, it was not perceived as deceptive in English Canada, where the idea of citizens' rights was so popular that it overrode other considerations (Clarkson and McCall 1990, 187).

I have attempted to demonstrate that in 1981-1982, aided and abetted by the turpitude and missteps of Lévesque and his government, Trudeau and the premiers of the majority English-speaking provinces joined forces to transform Canada's constitutional order and national identity without Québec's consent. As in all complicated social phenomena, there were many causes, responsible agents, and consequences. As Burelle (2005) indicates in the conclusion of his book, there are ways to act politically beyond the legacy of the 1981 Patriation Conference and of its legal consequences. Until now, Canadians, and Québecers in their midst, have failed to embark on such a journey. In the end, the enchantment of Burelle's prose brings precious little consolation for the political and constitutional distress of many Québecers, myself included, in contemporary Canada. 


\section{CHAPTER 9 \\ The Canadian State and the Political Freedom of Québec}

\section{The Ideas of James Tully and Michel Seymour}

Philosophical and political debates concerning the nature of the Canadian state, Québec's right to self-determination, and the legality and legitimacy of a secessionist approach have lost much of their intensity in Québec and Canada generally over the last decade. All across Canada, constitutional issues have been relegated to a very secondary role in political life, partly owing to the extreme rigidity of the amending formula. ${ }^{1}$ In this chapter, I consider the works of philosophers James Tully and Michel Seymour on the topic of Québec's political freedom within the Canadian state, being fully aware that I am engaging in hermeneutic work in political thought belonging to the history of ideas. I cannot imagine how my reflections could have any political influence in the country where I live in the short or medium term. However, it seems that, as Scotland prepared to hold a referendum on September 18, 2014, and while Catalonia attempted to convince the Spanish government to let it organize a consultation process on its future in early November 2014, interpreting Tully and Seymour's thoughts on the Canadian-Québec situation could shed instructive light in contexts where there is institutional blockage and strong political tension.

Tully is a leading political philosopher in contemporary Englishspeaking Canada. A similar remark can be made about Seymour in French-speaking Québec today. Both thinkers published major works in 2008. Tully published the two-volume Public Philosophy in a New Key (2008), which placed him at the cutting edge of a global political theory fighting against imperialism in all its forms, and in very close contact with the civic practices of freedom and dialogue. Seymour published De la tolérance à la reconnaissance (2008), an analysis based on the second Rawls, the Rawls of political liberalism, aiming to go beyond moral individualism and its predilection for autonomy, arguing in favour of substantial recognition for stateless peoples (more precisely, peoples that do not have completely sovereign states), which would take the form of a system of collective rights. In this chapter, I do not perform an in-depth

See Réjean Pelletier (2009: 76). See, also, Brooks (2009: 146-152). 
comparison of these two recent analyses. Instead, the focus is on texts that are on the whole less important, in which Tully first came to conclusions diametrically opposed to Québec's political freedom in Canada. In a 1999 text written in the wake of the famous Supreme Court of Canada decision concerning the secession of Québec, translated by Jocelyn Maclure and published in the journal Globe, Tully said things that were extremely critical of Canadian constitutionalism. His comments have since often been repeated by Québec intellectuals, especially by thinkers in favour of the sovereigntist cause:

Canada, since its constitution is in fact a straightjacket, in other words, a structure for domination, is thus in this respect not a free society. The recognition of an internal right to self-determination for a people struggling for a form of recognition is one of the necessary conditions for overcoming this impasse (Tully 1999b, 17. My translation).

Less than a year later, at a conference that he gave in the Québec Studies Program at McGill University, directed by Alain-G. Gagnon at the time, Tully came to a radically different conclusion. Expanding his vision of the radically revolutionary nature of the Supreme Court's decision in Reference re Secession of Québec, a judgment that he considered among the most important in all of the history of democratic constitutionalism, Tully argued that Canadian constitutional democracy, as re-interpreted by the highest court in the land, gives Québec all of the guarantees it needs to enjoy its right to internal self-determination within Canada (Tully 2000, 31). In so far as Tully is both one of the leading thinkers on pluralism and political freedom in Canada and a pioneer in the theoretical study of multinational democracies, such a reversal in his interpretation is highly significant. Whatever the reason, it seems to me that, for a number of years, Tully's substantial reversal was largely received with deafening silence by intellectuals in French-speaking Québec. That was until Seymour, first in an essay published in 2001 and then in a recent text, struck up a critical dialogue with Tully concerning both the nature of the right to internal self-determination of non-sovereign political communities in encompassing states and also on the specific situation of Québec in Canada. There has not yet been a debate between Tully and Seymour in that Tully has not yet responded to Seymour's criticism. I hope that this chapter will pave the way for such a debate in the near future. In multinational federations, open, rigorous, and respectful critical exchanges are always preferable to silence and mutual indifference.

I will begin with a brief review of the broad lines of Canada's recent political-constitutional history, which has been strongly influenced by Québec's attempts to either expand its autonomy or achieve full political sovereignty. Next, I will provide an overview of Tully and Seymour's 
respective careers in political philosophy. In the third stage, I will perform a synthesis of the two texts in which Tully first endorses and then rejects the thesis that Canadian constitutionalism is equivalent to a straightjacket for Québec. This will be followed by an examination of Seymour's criticisms of Tully's approach, leading to the formulation of my own interpretation, which involves moderating the positions on both sides and providing some keys to a better understanding of Tully and Seymour's arguments employing current work in political philosophy, political sociology, and the history of ideas.

\section{Canada's Political-Constitutional Identity and Québec's Situation}

In political science publications and works on Canadian and Québec studies, there is no lack of high-quality scholarly work on the issue of the Canadian state in modernity and Québec's history within it. When Canadian diplomats go abroad, they take with them the official portrait of the country, which is quite similar to that painted in 1998 by the highest court in the land in its famous decision on Québec's secession. This Canada is a constitutional monarchy in the British tradition, a representative liberal democracy, a state in which there is rule of law paired with a parliamentary system, and a federal multination-state that is independent, bilingual, and multicultural. This country of over 34 million people is made more complex by the presence of Québec, the only province in which there is a French-speaking majority. (More than 80 percent of Québecers are of French or French-Canadian heritage, and 97 percent of the 8.1 million Québécois speak French). Québec made substantial contributions to Canada's original historical and political configuration. Canada is often considered around the world as being on the cutting edge of civilization based on its toleration of difference and openness to a multiplicity of identities, though it owes this largely to Québec (Kymlicka 1995; 1998).

Moreover, like Canada as a whole, Québec is composed of three layers of profound diversity: a national minority that is concentrated in Montréal, Aboriginal peoples, and a large section of the population resulting from immigration. Nearly fifteen years ago, Michael Ignatieff tried to identify how the panoply of rights that exist in Canada makes it a legal environment that is unique in the world. According to him, this is a result of a combination of four types of rights: relatively avant-garde liberal rights on complex moral issues such as abortion; a generous conception of social democracy, visible in wealth redistribution programs for underprivileged individuals and communities; collective rights for groups; and, finally, in the wake of Reference re Secession of Québec, the possibility for a member-state to leave the federation in full legality (Ignatieff 2001, 
25-26). In its 1998 decision, the Supreme Court summarized in its own way the political-constitutional history of the country, highlighting four implicit or underlying principles that complement the major constitutional documents specifying Canada's identity: federalism, democracy, constitutionalism and rule of law, and, finally, respect for minority rights. As will be seen here, Tully gives special importance to the court's interpretation in its decision. I shall complete this brief overview with a list of four principles taken from a text by Alain-G. Gagnon and myself $(2009,16-20)$.

\section{A. The Role of the State in Building a Strong, Distinct Canadian Nation in North America}

In the history of Canada, the state has always been a strong identity marker for distinguishing Canada from the United States. In 1867, the federal Dominion of Canada was created to promote peace, order, and good government. The tone was set. Erected as a protector of individuals and communities, the state took concrete form in a desire to expand across the continent, from east to west, and this was renewed through five major national policies: the establishment of an economic policy behind a tariff wall; the construction of the railroads in the $19^{\text {th }}$ century; the immigration policy designed to populate the Western provinces and then the rest of the country; the consolidation of a welfare state after 1945; and, finally, the identity-related legal system associated with the Canadian Charter of Rights and Freedoms since 1982.

\section{B. British Heritage from Yesterday to Today}

Canada's parliamentary and state system stems from its historical genesis under the control of the British Empire. To this was added a political culture of evolution or, in other words, gradual change, including constitutional amendments. This was done without neglecting the reproduction, in the relations between the political and bureaucratic elites of the Canadian federation, of a hierarchical vision of relations between the centre and the periphery similar to that prevailing when the British Empire played a greater role in our affairs.

\section{The Federal Principle (or Autonomy Principle)}

The question of the federal or autonomy principle's nature, as well as that of fine-tuning its real role in balancing political-constitutional principles, is at the heart of my thinking in this chapter. As in most multinational federations, the historiographical traditions of the majority and minority nations in Canada - which remain more complex and pluralist than is generally acknowledged - tend to diverge widely on these issues. In Québec, as a general rule, political leaders, intellectuals, and academics who are 
interested in studying federalism and how it is practised tend to give it greater moral and existential importance than do their colleagues elsewhere in Canada. In other words, when one leaves Québec, the substantive dimensions of political identity in Canada are to be found elsewhere than in federalism. François Rocher has showed this in a convincing manner. He recently pointed out that the dominant interpretative tradition in Québec concerning the genesis of Canadian federalism and its evolution has taken the form of a contractual, dualist prism, maintaining the idea of a pact designed first and foremost to preserve Québec's autonomy, having in mind the greater end of preserving and promoting what makes Québec different (Rocher 2006). In contrast, in the rest of Canada, the dominant perspective has tended to avoid giving federalism too much moral value, and has focused on functional and instrumental aspects. It has employed the language of performance and efficiency. Of course, all of this has been in the service of a greater end, namely first and foremost preserving the unity of the nation-state.

\section{Québec's Contribution to Maintaining Canada's Originality and the Indispensable, Crucial Role of the State in Shaping Québec's Difference}

For the Canadian government and its nation-building project, there is a Québec that is reassuring. It is the one in which the simple presence of a huge French-speaking population living in the modern age in a language other than English gives the country a strong means of distinguishing itself from the United States. This reassuring Québec is the one that has fuelled and continues to fuel a Canadian dualism that can be found in the bilingual nature of the country, the equally primordial status of two systems of law (common law and civil law), two complete societies integrating immigrants, the complex associative fabric of two civil societies, two communications and technological networks, and two research communities that are both independent and linked. Next to this reassuring Québec, there is of course another, which is much more worrying to Canadian nation building. The worrisome Québec needed to strengthen its own state structures in the second half of the $20^{\text {th }}$ century to accompany and give direction to the deep processes of social modernization known as the Quiet Revolution. The dynamic energy of Québec society during the time of the Quiet Revolution thus fuelled the idea of Québec nation building, competing with Canadian nation building. The clash between the two nation-building undertakings was expressed in plans designed to deeply reconfigure the structure of Canada but without challenging its unity or integrity. This was the goal of renewing Canadian federalism, especially in the years 1965-1968 and 1977-1979, as well as 
during the time of the Meech Lake and Charlottetown Accords between 1987 and 1992. However, this clash was also expressed in the dreams of the pro-independence and sovereigntist movements in Québec, which sought to bring to completion a certain idea of nation-state normality for Québec and to redefine relationships with Canada in the 1980 and 1995 referendums on, respectively, sovereignty-association and sovereignty-partnership.

Across Canada, but in a more heightened manner in Québec, the postreferendum years were characterized by very tense political climates and deep bitterness in the political classes and civil societies on both sides. In August 1998, the Supreme Court of Canada changed the atmosphere by giving arguments to both the sovereigntists and the federalists, as we shall see. A year later, in December 1999, the federal government, led by Jean Chrétien, introduced Bill C-20 into Parliament. This bill (hereinafter the "Clarity Act") implemented the clarity requirement formulated by the Supreme Court in its Reference re Secession of Québec. At the same time, the Québec government, led by Lucien Bouchard, introduced Bill 99 into the Québec National Assembly, noting the Québec people's fundamental right to determine its future through its institutions and in compliance with the democratic rule of fifty percent plus one.

To give an idea of the atmosphere at the time, I will juxtapose two texts, respectively written by Alain-G. Gagnon and James Tully during a period when, in parallel with their own personal research, they were directing pioneering reflection on multinational federations around the world:

The Canadian condition seeks to force Québec to be nothing more than a province like the others in the federation [...] Breaking with the founding constitutional order through the 1982 repatriation, Québec-Canada relations have entered a phase of non-recognition and impoverishment of democratic practices. The Supreme Court's opinion on Québec's right to secede expanded the field of possible scenarios, but was immediately placed in a framework and limited by the federal government, which clearly wants to avoid a deep debate on the federation's future [...] In short, the Canadian federal experiment will be worth continuing only if the member states are free to endorse the federation and any form of domination structure is prohibited (Gagnon 2003a, 174-175).

Alongside their strong sense of belonging to Canada, the members of the English-speaking minority in Québec have developed a strong sense of belonging to and identification with Québec society over the last forty years by virtue of their participation in the public debate over Québec's future. This is because they have taken part in the discussions and have played a participatory role in the demands for renewed federalism. The moment they are shut out of the discussions, however, as during and after the referendum of 1995, and their demands for recognition as a minority fall on deaf ears, this sense of 
Québec citizen belonging and identification dissipates, many leave the province, and the hardline demands of those who remain increase, such as partition in the event of secession (Tully 2008, vol. I, 211-212). ${ }^{2}$

\section{The Philosophical Approaches of James Tully and Michel Seymour}

James Tully is established at the University of Victoria, where he is a Distinguished Professor of Political Science, Law, Indigenous Governance, and Philosophy, after having spent around 20 years as a professor of political science and philosophy at McGill University in Montréal. His principal works are on modern and contemporary political philosophy, Canadian political thought, and constitutional theory. I suggest that three stages can be seen in his intellectual career. First, he deepened the methodological and hermeneutic approaches of his mentors at Cambridge, John Dunn and Quentin Skinner, by focusing on $17^{\text {th }}$ and $18^{\text {th }}$ century political thought, and in particular, through detailed research, on the philosophy of John Locke. ${ }^{3}$ Second, unquestionably inspired by the political and constitutional crisis in Canada and Québec, with which he was in close contact while at McGill University, Tully suggested a critical interpretation of the traditions of thought associated with modern constitutionalism in the hegemonic political undertaking of a sovereign nation-state oriented towards cultural homogeneity. The work that he did during this period made him, along with Charles Taylor and Will Kymlicka, a key player in a truly Canadian school of research on identity and recognition policies. That school promotes differentiated citizenship that is able to expand its categories to the rights of all minorities, and that indeed seeks to identify the theoretical and practical conditions for achieving justice and stability in multinational democratic federations. ${ }^{4}$ According to Tully, every struggle for recognition is a way of participating in a fundamental quest for freedom and for the self-determination that consists in being able to change the complex rules of governance that characterize our political life in all its forms. At the junction of theory and practice, political philosophy accompanies these struggles for recognition and freedom by revealing the conditions of possibility, which are simultaneously material, institutional, and intellectual systems of governance that apply to citizens today.

\footnotetext{
2 Here, Tully re-employs a passage from the introduction to Multinational Democracies (Tully 2001).

3 In particular, see Tully (1993).

4 See, in particular, Tully (1995).
} 
In the second stage of his career, Tully gave primary importance to Aboriginal peoples' worldwide struggles for recognition in the face of the "empire of uniformity," hegemonic nation-state building, and modern constitutionalism. Without abandoning the theoretical and methodological achievements of earlier periods, and influenced in particular by his dialogue with thinkers such as Foucault, Habermas, Skinner, Taylor and Wittgenstein, Tully now seeks to go beyond the horizon of struggles for recognition by defining a theoretical undertaking that is both more global and more ambitious. He seeks to accompany, with the weapons of critical lucidity, the civil approaches and resistance to imperialism in all its forms around the world since the beginning of the $21^{\text {st }}$ century (Tully 2008). The inter-related resistance movements form what Tully calls a crisis of global citizenship confronted with the problems of world wars and militarization; the ecological crisis and climate change; deepening inequality, poverty and exploitation in countries in the Southern Hemisphere; and, finally, disrespect and distrust of the diversity of civilizations and peoples. In the field of political theory, Mark Wenman has suggested using the expression "agonistic pluralism" to describe Tully's undertaking, associating it with the approaches of Chantal Mouffe and William Connolly (Wenman 2003, 174-176). Tully considers that, more than ever, the multifarious faces of imperialism require theoretical vigilance and practical commitment from people seeking to deepen the spaces in which they are free. The following excerpt gives a good idea of the current orientation of Tully's research in the third stage:

If all the millions of examples of civic and global citizenship practices could be taken in a single view, as the tradition of modern citizenship and globalization presents its inexorable progress, perhaps this would help to dissipate the sense of disempowerment and disenchantment the present crisis induces. But, from the situated standpoint of diverse citizenship, this cannot be done and the attempt would overlook the very diversity that the civic approach aims to disclose, keep in view, learn from and work with. Civic empowerment and enchantment do not come from grand narratives of universal progress but from praxis - actual participation in civic activities with others where we become the citizens we can be (Tully 2008, 308).

Michel Seymour is Full Professor (in French, professeur titulaire) in the Department of Philosophy at the Université de Montréal. His primary work concerns theories of justice and recognition in multinational democracies, philosophy of language, and theories of nationalism and federalism. He writes in both French and English, and, like Tully, his work has brought him many awards and distinctions in Québec and across Canada. In terms of politics, Seymour is ultimately a sovereigntist. He no longer believes that Canada can become a true multinational federation able to make adequate room for Québec's difference and its aspiration 
for political freedom. Seymour is in particular the author of two major works on the rights of peoples and minorities. The first, concerning more specifically the Canada-Québec dynamic, was published in 2001 and is entitled Le pari de la démesure: l'intransigeance canadienne face au Québec (Beyond moderation: Canadian intransigence towards Québec). Discussing all of the sensitive issues in the Canada-Québec relationship that were debated in the 1990s, such as the Supreme Court's Reference re Secession of Québec, the Clarity Act, and partition, his work nonetheless begins with a description of the historical framework for these relations. According to Seymour, it is clear that these relations have been characterized by constant rejection of Québec's demands for recognition and, in the end, Québec itself (Seymour 2001, 102). The rejected demands led, moreover, to the 1995 referendum on sovereignty, which was linked with the above-mentioned issues discussed by Seymour. In the book, Seymour suggests an approach for acceding in the future to sovereignty associated with an offer of partnership with the rest of Canada. If Canada accepts, Québec would win a sovereign state with a fair, sustainable partnership relationship with Canada. If Canada refuses, Québec could then legitimately declare complete sovereignty (Seymour 2001, 294-306). It is thus clear to Seymour that the path to sovereignty is not conceived of as an end but rather as a means for Québec to employ its right to self-determination. In Le pari de la démesure, Seymour takes a clearly partisan, and often controversial, point of view (Seymour 2001, 11). His essay is a reaction to the earlier publication of a book entitled Straight Talk (published in French as Le pari de la franchise) by his former colleague at the Universite de Montréal, Stéphane Dion, who was then the Minister of Intergovernmental Relations and President of the Privy Council in Canada's federal government under Jean Chrétien. All work in political philosophy offers a balance between specificity and universality. While the former carried more weight in Seymour's 2001 essay, it is clearly the latter that is dominant in his 2008 book though he never loses sight of Canada-Québec relations.

The book that Seymour published in 2008 is extremely ambitious. Kymlicka tried in his 1995 book, Multicultural Citizenship, to deepen the deontological philosophical liberalism of the first Rawls by making it more hospitable to minority rights, whereas Seymour sought in 2008 to justify a collective rights regime for peoples without completely sovereign states based on the second Rawls, the one of Political Liberalism and The Law of Peoples (Rawls 1993; 2001). It is difficult to render justice in only a few lines to Seymour's ambition and toil in a work of nearly 700 pages. Like Tully, Seymour is indebted to Charles Taylor, founder of the Canadian school of pluralism, dialogue, and recognition. Indeed, the first chapters of his book belong to the philosophical anthropology dear to Taylor. Before formulating his own liberal theory of collective rights, 
Seymour also discusses at length Kymlicka's work, which he considers too dependent on moral individualism to provide recognition and a legal framework adequate for stateless peoples. The philosophical perspective presented in his 2008 work is that of political liberalism with a universal vocation. It is not more closely related to the Canadian situation than is Tully's theoretical approach, although Québec and Aboriginal nations are regularly cited as examples of possible subjects of collective rights, like other minority nations (for example, Catalonia and Scotland) within nation-states elsewhere in the world. Endorsing, like Tully, the importance of recognizing minorities within states, Seymour thus challenges the dominant model of the modern, normal nation-state, which he considers obsolete. Although groups such as minorities resulting from immigration and contiguous diaspora communities can, according to Seymour, make certain demands for recognition, he advocates the need for nation-states to mainly recognize the rights of the nations within their borders, and to thus adopt a more multinational system. In this, he is in line with theorists and thinkers such as Tully, Gagnon, and Requejo.

His arguments are based mainly on Rawls' later philosophical work, and he takes up some of Rawls' parallels between individual rights and the rights of peoples. According to Seymour, the value of tolerance and the ideal of self-determination that apply to persons in an individualist framework can be applied to the issue of peoples in a form of axiological pluralism that postulates that the rights of individuals and peoples are of equal importance (equally primordial) and are not to be ranked (Seymour 2008, 270). According to him, recognition of peoples flows equally from a moral principle based on justice as from instrumental reason that calls for recognition of minority nations as a means of ensuring political stability. Seymour takes a direction similar to that found in Gagnon and Tully's pioneering 2001 work on multinational democracies, which sought to delve deeper into the twofold quest for justice and stability. The stability in question can be seen at both the domestic level, thus within the state, and the global level, since a nation-state's rejection of recognition demands from a minority nation increases tension and justifies, even for Seymour, a right to secede in virtue of the people's right to selfdetermination (Seymour 2008, 470).

Unlike Tully, Seymour is not opposed to modern constitutionalism as such, but rather to the nation-state framework that has resulted from it. This is to say that today's constitutions could prove capable of recognizing the diversity of nations and cultures if they were amended in certain ways. The changes that are required, according to Seymour, go far beyond simple symbolic recognition. In fact, what is in question is a system of collective rights understood as "rights that a community has and that make it possible 
for the integrity, development and promotion of institutional, collective and identity-related goods to be politically guaranteed within a given territory" (Seymour 2008, 481). In summary, from Seymour's point of view, peoples - and this applies both to stateless peoples and to those that are identified with sovereign states - can be valid sources of moral claims. Moreover, this translates into a collective rights regime co-existing, in an equally primordial way, with an individual rights regime. Neither Seymour nor Tully believes that political philosophy can rank or establish a lexical order of these types of rights in a disembodied manner, sheltered from the practical judgment of a community of citizens engaged in dialogue.

\section{From a Straightjacket to a Reworking of Democratic Constitutionalism with Universal Scope}

Tully has always indefatigably insisted on the complexity and diversity of struggles for recognition of difference in culture and identity. To take only the example of cultural and national struggles, far from opposing fixed entities that would be separate and uniform seeking a classical, definitive, permanent form of recognition, such clashes instead involve groups containing plurality and complexity within themselves, against a background of interwoven identities. The field of these struggles will thus be that of an unceasing, permanent dialogue the outcome of which can always be challenged:

An identity negotiated in these human, all too human, circumstances will not be fixed or authentic, but it can still be well supported rather than imposed, reasonable rather than unreasonable, empowering rather than disabling, liberating rather than oppressive. That is, it will be a construct of practical and intersubjective dialogue, not of theoretical reason on one side or immediate ascription on the other (Tully 2003, 519).

I think that this approach, which places the accent on the complexity and diversity of struggles concerning identity and constitutional issues, can be found in the two texts that Tully devoted largely to the topic of Québec's political freedom within the Canadian state. The 1999 article, entitled "Liberté et dévoilement dans les sociétés multinationales" (Freedom and disclosure in multinational societies), and the spring of 2000 conference held at the Québec Studies Program at McGill University, "The Unattained yet Attainable Democracy: Canada and Québec Face the New Century," are thus in line with his overall philosophical approach. As shall be further developed here, in these two texts, Tully places great importance on the notion of political freedom understood as the self-determination of peoples. In both instances, he believes that the Supreme Court of Canada did pioneering, even revolutionary, work in the 1998 Reference re Secession of Québec, particularly with respect to the fundamental dimension of peoples' 
freedom. However, between the two texts, Tully strengthened his understanding of the meaning and scope of the decision to completely reject the thesis of the first text, which was that the Canadian constitutional framework had become a shackle or straightjacket for Québec.

The intersubjective action of competition for a certain form of recognition (an activity that should not be confused with the final outcome of the struggle) can be understood as mutual unveiling and acknowledgement. Struggles for recognition are also actions in which one reveals oneself [...] The primary stake is thus not recognition, but freedom. The freedom of the members of a society to change the constitutional rules of mutual recognition in concert with the changes that occur to their own identity [...] This is why groups with claims now demand that this intersubjective activity be enshrined in the basic structure of their society. Indeed, a multinational society will be free and respectful of the right to self-determination in so far as the constitutional rules governing association among different nations are open to challenge and amendment $[\ldots]$ At the dawn of the new millennium, the shift between freedom and domination will be the primary political issue in multinational societies (Tully 1999b, 14-16).

As his article progresses, Tully deepens his understanding of the struggles for recognition, which leads him to the views of the second stage of his philosophical career. He links his approach with crucial political-constitutional events in Canadian-Québec history since the Parti Québécois' first victory in 1976 and with the main aspects of the Supreme Court's 1998 decision. According to his approach, the various parties involved in demanding recognition have to see themselves as legitimate interlocutors participating in discussions and negotiations. Tully sees the idea of mutual reciprocity as the key principle of recognition policy. He believes that the Supreme Court's Reference, by setting aside the unilateral aspect of a secessionist approach, was clearly following the logic of this principle (Tully 1999b, 19). At the different stages that constitute a demand for recognition, the stakeholders reveal to themselves and others their own identities by formulating the demand, and their partners are obligated to listen and to take into consideration the content of the demand. On this issue, Tully also finds that the decision, since it recognizes an obligation to negotiate with all members of the Canadian political union in the wake of a referendum on a clear question resulting in a clear majority, respects the broad lines of his theoretical approach. It is important to note that, for Tully, both the association member that demands recognition and those that respond have to respect their internal diversity at all stages in the process. Tully - who for some ten years has been co-leading with Alain-G. Gagnon research on the political regimes of Great Britain, Belgium, Spain and Canada - considers that in contemporary multinational societies recognition of members' national identity 
is a free, democratic activity with four characteristics: it is intersubjective and does not claim authenticity because it is constantly being formed and reformed; it is multilogical, bringing into contact a wide range of stakeholders with identities that are also plural and shifting in their exchanges among negotiation, persuasion, deliberation, questioning and other forms of rhetoric; it is continuous, full of too much complexity and unpredictability to lead to something final or definitive; and, finally, it is agonistic in so far as exchanges related to recognition are also forms of competition. Globally, demands for recognition are thus part of open, partial, indefinitely revisable processes that can enable members to challenge and transform the rules that define the way they live together in their politicalconstitutional association. Despite all the respect owed to the Supreme Court and the quality of its decision, Tully nonetheless considered, in 1999, that the Canadian constitutional regime was a straightjacket for Québec. His reasoning was based on the three following arguments:

There are three reasons why Québec is not free within the Canadian federation. First, the other members of the federation can impose constitutional amendments on it without its consent. They can also arbitrarily block any negotiations designed to give Québec the constitutional status of nation. In 1982, a constitutional amendment, namely, the Constitution Act, 1982, was introduced and imposed on Québec without its consent and despite its clearly asserted dissent. This manoeuvre not only violated a constitutional convention (Quod omnes tangit), as the Court ruled at the time, but also violated the new amending formula established by the Constitution Act, 1982 [...] The Supreme Court found that Québec is nonetheless bound by the Constitution Act, 1982, and, consequently, by the amending formula it contains [...] However, the Court added, this time rightly, that this general rule applies only when the constitutional rules that are adopted can themselves be amended. It is this aspect that is now in question.

The second reason that Québec is not free within the Canadian federation lies in the fact that the content of the amending formula introduced in 1982 entails that it is virtually impossible, in practice, to amend the Constitution in such a way that Québec is recognized as a nation. Third, the Court holds that phase two of the negotiations, triggered by a clear majority in a referendum on a clear question, should be governed by the present amending formula. Yet, owing to the first reason mentioned above, Québec is not bound by this amending formula (Tully 1999b, 31-32).

Shackle, straightjacket, domination, and deprivation of political freedom are the terms that summarize this view. Since the beginning of modern times, these words and others belong to the register of negativity and indignation in the semantics of political thought and action, and this could not have escaped such a renowned interpreter of Locke as Tully. This language belongs to arguments proclaiming the illegitimacy 
of a political relationship and inviting people to contemplate alternatives in complete theoretical freedom in order to recover practical freedom. Indeed, it always has to be possible to challenge and change the politicalconstitutional rules for living together in order to claim a free political life. In the months that followed the writing of this article and in conditions that it will perhaps one day be possible to elucidate for the benefit of Canadian intellectual history, Tully re-analyzed the entire August 1998 Supreme Court decision, and thereby gained a better grasp of its structure and revolutionary scope. This led him to conclusions that, according to his altered perspective, are more promising for Canadian constitutional democracy and for a means of promoting a form of diversity compatible with preserving the country's unity. I will now follow the path of his arguments at the March 2000 conference in Montréal: "The Unattained yet Attainable Democracy: Canada and Québec Face the New Century." In order to simplify the reading of this chapter, I shall use the expression "Montréal conference" to refer to this text.

In a decision with revolutionary scope and that could have universal consequences on deepening the goals of freedom and recognition in modern political aspirations, the Supreme Court seems to have significantly influenced the way that we must understand the Canadian constitutional regime by defining it as a system of rules and principles favouring reconciliation of unity and diversity through ongoing processes of democratic discussion, deliberation, negotiation, and change (Tully 2000, 4). Here we find a reading that is entirely compatible with Tully's theoretical approach concerning struggles for constitutional and identity-related recognition in today's world. According to Tully, the Supreme Court's interpretive prism opens a path to deepen and consolidate democracy in Canada. In other words, according to Tully, the decision enables Canadians and Québecers to continue to hope. We can still advance towards achieving democracy and freedom. Not all avenues are blocked. The Canadian constitutional system is not a straightjacket for Québec (Tully 2000, 6-7). This conclusion is the one that the Court itself formulated in its decision, and this time Tully makes it his own with great enthusiasm. From his point of view, in order to agree with the Court, we have to accept that constitutional negotiations are an unceasing, permanent activity, and thus abandon the illusion that definitive recognition is an end in itself.

As a general rule, according to Tully, those who have analyzed the Supreme Court decision have focused greatly on paragraphs 83 to 147, in which the justices apply the historical-constitutional principles that they identified in paragraphs 1 to 82 in order to answer the specific questions that the federal government referred to it. In that second part, the Court 
concluded that Québec has no unilateral right to secede under Canadian constitutional law or international public law. However, the Court also concludes that if there is a clear majority on a clear question concerning secession (but not only secession), then the members of the Canadian political association should enter into a complex process of negotiation with one another. By doing this, according to Tully, the decision already had a revolutionary aspect in the history of thought and modern political life: "No other court of a contemporary constitutional democracy has brought the process of secession under the orderly rule of law and democracy" (Tully 2000, 8). However, during the Montréal conference, Tully wanted to focus his attention on the first part of the decision, in which the Court redefined the Canadian constitutional framework by highlighting, in addition to the major written documents such as the Constitution Act, 1867, Constitution Act, 1982 and the texts, customs and conventions associated with Canada's British heritage, a series of four underlying principles that are implicit, inter-related, equally primordial, and at the very foundation of our political-constitutional system: federalism, democracy, constitutionalism and rule of law, and, finally, respect for minority rights. The Court found, and Tully is in complete agreement, that the partners always have to act in compliance with these principles, entirely banishing any recourse to unilateralism. They have to do so when they initiate constitutional changes, including secession, and they have to do so when they negotiate among themselves and continue to do so throughout any specific phase in the ongoing process of discussion and deliberation. To participate in such discussions while complying with written law and respecting the underlying principles is to advance in practice toward reconciliation of member diversity with the requirements of unity (Tully 2000, 9). In the end, the Court ruled that unilateral secession is impracticable for Québec because, as Tully says, it "would violate each of these four principles to which Québec has bound itself as a member of Canada" (Tully 2000, 9). ${ }^{5}$

Legal interpretation, as an integral part of hermeneutics in the sense of, for example, Gadamer's philosophy, always contains an applied element. Tully tries to render justice to the Court's interpretative work by noting that it sought to identify a non-exhaustive, non-definitive list of underlying principles, with an eye to application in situations requiring reconciliation of diversity with unity, as well as to the three fundamental sources of law: constitutional texts, historical context, and all relevant case law. The four principles that the Court identified are those that it

5 Here, Tully cites paragraphs 91 and 149 of the decision. 
felt were especially relevant in the specific context in which the decision would be applied.

Tully said during the Montréal conference that the Supreme Court of Canada initially considered that the four underlying reconciliation principles bound Québec and the other members because they had consented to those principles and those principles had been employed constantly between 1867 and 1998. Canadian constitutional democracy binds members because it is the house that they have built together, a complex process of creating and recreating themselves (Tully 2000, 13). ${ }^{6}$ Next, the Court focused on the task of understanding the principle of federalism, showing that it can be understood as both the governmental autonomy of the members and protection of their identity-related distinctions, including recognition of collective rights for a linguistic and cultural minority concentrated in an area, such as Québec (Tully 2000, 14). According to Tully and the Court, it is precisely because this underlying principle is real and fundamental that it has made possible an evolution of Canadian law going beyond the centralizing tendencies of the Constitution Act, 1867. In its interpretation of the democratic principle, the Court insisted on the idea, dear to Tully, of a political-legal regime understood as an ongoing process of discussion, recognizing that there will always be disagreement, but that it is important to always remain open to transforming rules from a stance of institutional modesty. The joint operation of these first two principles protects Québec's freedom and identity (through the logic of empowerment) while enabling it to participate in the creation and evolution of Canada as a whole (through the logic of integration). In relations between the different principles, neither can be used as a trump permitting one of the principles to be given priority and placed in a dominant position over the others. Indeed, it was in its discussion of the democratic principle that the Court felt that negotiations concerning the secession of Québec should be conducted by the elected representatives of two equal, concurrent majorities: a clear majority of Québec's population and a clear majority of Canada as a whole, without either being able to dominate the other a priori (Tully 2000,18 ). ${ }^{8}$ In the overall discussion about whether the Canadian constitutional framework is a straightjacket for Québec, these passages were crucial for Tully's conclusions at the Montréal conference.

During the Montréal Conference, Tully more quickly goes over the two other principles: constitutionalism and rule of law, and minority rights.

\footnotetext{
6 Here, Tully interprets paragraphs 49 to 54 of the decision.

7 Here, Tully interprets paragraph 59 of the decision.

8 Here, Tully interprets paragraphs 66 and 93 of the decision.
} 
However, like the Court, he believes that neither Québec nor Canada can take action without deep respect for its internal pluralism. Moreover, the Québec that resists unilateral actions at its expense should be willing to accept that the principle of constitutionalism prohibits it from taking any unilateral secessionist action.

The idea that Canada and Québec would have come to a constitutional impasse seems to Tully to be the result of a major misunderstanding. In the first part of its decision, the Court did indeed formulate a profoundly original understanding of Canadian constitutional democracy "as a flexible and continuous process of reconciling diversity with unity (among other problems) by means of negotiations in accordance with the appropriate written and unwritten constitutional principles" (Tully 2000, 20). The heart of the problem concerns the repatriation of the Constitution in 1982, culminating in a new fundamental text that includes the Canadian Charter of Rights and Freedoms. According to an initial perspective endorsed by the Court and by Tully, the conditions (Tully writes: "the evolving conditions") that made possible the Court's original, novel vision came to maturity in 1982. However, many people have committed the mistake of reducing the Canadian constitutional framework to only the text of the founding act of 1982, to only the procedures employed in the repatriation operation, and to the special way that a specific ranking has been made concrete with respect to the underlying principles that are now set forever. If we look at things in this way - and while Tully does not say so, this is how he saw things a few months before in an article published in Globe - the Constitution can be seen as a straightjacket and the entire political situation comes to an impasse. Tully wants to continue the Court's work by liberating us from this deep misunderstanding. In the last part of his conference, he discusses examples that provide greater detail concerning the idea that the Canadian constitutional framework should absolutely not be seen as a straightjacket (see, paragraph 150).

Tully subscribes with enthusiasm to the Court's idea that the Canadian Charter of Rights and Freedoms is not a straightjacket for Québec. He defends a vision of the Charter that makes it a protector of individual rights, minorities, and majorities, thus promoting the duality of the linguistic communities across Canada while also respecting the distribution of powers among the provinces and under the aegis of a combination of amending formulas sufficiently flexible to make possible all sorts of serene intergovernmental and constitutional negotiations (Tully 2000, 23). ${ }^{9}$ All

9 The following excerpt is found there: "In particular, the Charter recognizes and protects the equality of the two official-language communities throughout Canada. This 
of these ways of reconciling diversity and unity make the Charter just as popular in Québec as in the rest of Canada, according to Tully. Based on the Court's new interpretation of the Canadian constitutional framework, Tully believes that we can skip over the fact that Québec did not consent to the Charter and that the text does not recognize a fundamental aspect of its diversity, namely its identity as a distinct society. With respect to the first issue, Tully notes that the Court defended the ideal of legal continuity, and recognized in its decisions at the time the concept of a qualified majority, without overlooking the fact that Québec's representatives in the federal Parliament did indeed, by a very large majority, give their consent to the Charter coming into force (Tully 2000, 24). Regarding the second issue, Tully concludes that, despite the lack of explicit recognition, some aspects of the Charter indirectly protect Québec's identity as a distinct society (in particular the fact that the Charter does not alter the distribution of powers or the possibility for Québec to have recourse to the notwithstanding clause). The events of 1982 were characterized by a series of compromises, negotiations, and deliberations. As always, dissent was inevitable (see, paragraph 68). What was essential, according to both the Court and Tully, lay in the openness to change and flexibility with respect to the future of the constitutional framework. We will be able to change the Charter in the future. The ranking of the underlying principles that made it possible to repatriate and bring into force the Constitution Act, 1982 does not make it a cage for the future. We thus have to see the repatriation process, the content of the Charter, and later democratic efforts to change it as representing the Canadian constitution in action, a continuing process of discussion and evolution with respect to rules and in compliance with rules.

Remember that, in the article published in Globe, Tully strongly insisted on the inflexibility of the amending formula's text and practices (in fact, a combination of amending formulas sometimes requiring a qualified majority of members and sometimes unanimity) and had concluded that the Canadian constitution was a straightjacket for Québec. At the Montréal conference, Tully rereads the relevant paragraphs of the decision (i.e., paragraphs $84,88,93,94,96$, and 101) to show that possible negotiations concerning secession have to be carried out by representatives of both majorities (see, paragraph 93) and in a manner consistent with the four underlying principles. A possible impasse owing to excessive inflexibility in the constitutional text's amending procedures

non-territorial and post-modern imagined community of Franco-Québecers, Acadians, Franco-Ontarias, Franco-British Columbians, and so on, with its deep historical roots, may, for all we know, turn out to be as strong as, and complementary with, Québec's territorialized nationalism. Only time will tell." 
cannot thus be considered a lock sealing the door from opening to negotiations and flexibility. In sum, Tully thinks that Québec is not deprived of political freedom in the functioning of the Canadian state. Its right to self-determination is not hobbled. This theme was the last one that Tully discussed in depth during the Montréal conference.

In its 1998 decision, the Court considered that, within Canada, Québec was not prevented from making significant use of its right to internal self-determination. It was able to achieve its economic, social, cultural, and political development. It was also entirely possible for it to take the democratic initiative to try amending the constitutional framework. Tully recognized that he himself had succumbed to a deep misunderstanding in an earlier text - when reading this passage, we have to understand that he is alluding to his Globe article - in which he limited the constitutional framework to the fundamental 1982 legislation alone and consequently mistakenly interpreted the issue of Québec's formal recognition and powers (Tully 2000, 30). The difficulties encountered in attempts to amend part of the constitutional arrangements in force in Canada - for example, the Meech Lake and Charlottetown failures - do not entail a negation of Québec's right to internal self-determination. Québec can work towards changing the rules and, if it does so in a manner consistent with the constitutional framework, its partners will have to listen to it and negotiate, which can even include negotiations concerning secession:

Whether or not Québecers constitute a people, they possess the powers of political, economic, social and cultural development associated with the right to self-determination and their distinct character as a diverse people, or peoples, is recognized by the Court in the fundamental principles and procedures of the constitution (Tully 2000, 31).

\section{Michel Seymour's Criticism}

In his essay published in 2001, Le pari de la démesure: l'intransigeance canadienne face au Québec, Seymour had already addressed a series of critical comments targeting the interpretations of Canadian democratic constitutionalism proposed by Tully. To my knowledge, no one in our research communities has yet tried to examine in detail the hermeneutic and political differences between these two philosophers. More recently, in "L'autodétermination interne du Québec dans la fédération canadienne" (The internal self-determination of Québec within the Canadian federation), at a conference given in Montréal in 2009, Seymour revisited his differences with Tully. I begin with a review of Seymour's main criticisms in the 2009 text.

Seymour begins by providing a very useful theoretical distinction between substantial internalself-determination and procedural-deliberative 
internal self-determination. He thinks that Tully's approach belongs to the latter category. Of course, internal self-determination has economic, cultural, and social dimensions, though I do not have enough space here to discuss the lively debate between federalists and sovereigntists as it relates to these three dimensions of Québec's internal selfdetermination in Canada. Like Seymour and Tully, I focus more on the political dimension of substantial internal self-determination. Seymour proposes three stages. First, he begins with substantial internal selfdetermination in the weak sense. A people has this when it can choose its representatives freely within the encompassing state - the Supreme Court insisted strongly on this dimension in paragraph 136 of the Reference re Secession of Québec. The next stage is the canonical meaning. This is the ability to enjoy an autonomous government by, for instance, possessing a federated state within a federation. Finally, the third stage is the strong sense. This is when the encompassing state offers differentiated rules of operation including various systems of asymmetrical federalism, tax policies adapted to internal national pluralism, and specific rights concerning international representation (Seymour 2009, 4-5). What kind of substantial internal self-determination does Québec have in Canada? Seymour's judgment on this is very severe. He thinks that such self-determination, such political freedom, is seriously hobbled. I shall come back to this in the next section. Indeed, Seymour approaches Tully's interpretative work from another point of view, that of procedural or deliberative internal self -determination. Here is the essential point in Seymour's reading of this:

According to Tully, the Supreme Court showed in its opinion on the secession of Québec that the 1982 constitutional order was not a shackle or straightjacket but on the contrary a living organism that authorizes the provinces to initiate action to amend the Constitution. The 1982 constitutional legislation would be a living organism because the constitutional conversation can continue $[. .$.$] According to Tully, "struggles for recognition are struggles of dis-$ closure and acknowledgment." Even if the process does not come to a happy end, you still have to be happy (Seymour 2009, 13-14).

The following is a list of Seymour's main objections:

(1) Tully's interpretative framework leads to an unbalanced process of reciprocal recognition between a majority people-nation and a minority people-nation within the encompassing state. Québec enters into the dialogue by accepting the idea that it is part of the Canadian political community, which is equivalent to recognizing that there is a Canadian people, and even that it has a right to external selfdetermination. However, Québec has to put up with the fact that recognition of its right to substantial internal self-determination is constantly being put off, since it has to be satisfied with seeing its claims simply considered or taken into account. 
(2) Despite the fact that he promotes deliberative democracy, Tully seems to have nothing to say against the 1982 imposition of a constitutional regime on Québec without its consent. According to him, as re-interpreted by the court, the 1982 constitutional regime even enshrines Canadian deliberative democracy.

(3) Seymour also enters into a debate with Tully concerning the inflexibility of the 1982 Constitution's amending formula. Tully's defensive strategy is to support the Court's idea that a way around such inflexibility will be found in possible post-referendum negotiations by employing a simplified amending procedure leading to negotiations between representatives of the two majorities (a Canadian majority and a Québec majority). Seymour thinks that this idea is completely unrealistic given contemporary Canadian politics.

(4) Expanding upon the second criticism above, Seymour believes that Tully contradicts himself by supporting the idea of negotiations based on a simplified procedure of two majorities for Québec's secession since he does not extend, in theory, application of such a rule to the 1982 repatriation of the Constitution without Québec's consent.

(5) According to Seymour, in Canada between 2000 and 2010, the constitutional conversation dear to Tully was not continued. "It was repeated to us ad nauseam that the time was not ripe and the ground not fertile for constitutional discussions" (Seymour 2009, 17).

(6) Given that Tully delivered his conference entitled "The Unattained yet Attainable Democracy" in Montréal a few weeks after the federal parliament adopted the Clarity Act, Seymour reproaches him for his silence on the legislation and its consequences for the admissibility of his interpretation:

$[\ldots]$ the lack of determination concerning what should count as a clear majority, the abandonment of the principle of a simple majority as the interpretation of the democratic principle, the veto that the Canadian government gives itself over what constitutes a clear question, the possibility of interfering in the process for adopting the referendum question in the National Assembly, the obligation to negotiate the partition of Québec, all of that does not upset him in any way. In short, through his silence on this issue, Tully seems to think that the Clarity Act in no way violates Québec's ability to initiate a constitutional amendment (Seymour 2009, 17).

(7) Seymour believes that by reassuring Canadians concerning the granting of a deliberative procedural right to self-determination for minority peoples and nations, Tully gives them reasons to postpone 
deepening and substantial internal self-determination, "taking us away from effective recognition rather than bringing us closer to it" (Seymour 2009, 17).

(8) By attributing to the Supreme Court of Canada great originality on the international scene for being, in 1998, the first court of both an advanced democracy and of a multinational society to acknowledge this condition of freedom and to formulate an appropriate account of democratic constitutionalism, Tully, according to Seymour, places the principles of deliberative democracy at the service of a nationalist apology for the Canadian constitutional regime.

I will complete this enumeration of the main differences between Tully and Seymour by returning to the chapter written by the latter on the Supreme Court's Reference re Secession of Québec in his 2001 essay, Le pari de la démesure: l'intransigeance canadienne face au Québec. In the end, Seymour does not share Tully's enthusiasm concerning the revolutionary nature of the decision and its capacity to be a springboard for real reforms that will strengthen federalism. Seymour argues that the Court's justices, far from having been above the fray, acted instead as veritable promoters of the Canadian constitutional regime, including the one that was established in 1982. According to Tully, the underlying principles that complement the major written constitutional documents are true instruments of flexibility. Seymour thinks that such "interpretative flexibility" can just as easily be used to set obstacles in the paths of reformers as it can serve the cause of advocates strengthening the federal principle (Seymour 2001, 154). Tully delivered his conference in Montréal in March 2000, only nine days after the Parliament of Canada adopted the Clarity Act (known as Bill C-20 at the time). In the legislation, as I noted in the second section of this chapter, the Canadian government invited Parliament to implement the clarity requirements formulated by the Court. In 2001, Seymour felt that it would have been useful if Tully had compared his interpretation of the Reference with that underlying the legal intervention by the central government of the Canadian federation. Finally, Seymour criticized Tully for transforming into a minor problem the absence of strong, effective recognition of Québec. As we know, the philosopher from Victoria relies on the dynamic, flexible nature of the constitutional regime, including the 1982 reform, and he points out that the courts already take Québec's specificity into account in their decisions. In sum, he suggests that implicit recognition of the Québec difference is an addition to the four underlying principles of the Canadian political-constitutional order. According to Seymour $(2001,156)$, this encourages Quebecers and Canadians to be satisfied with the status quo. 


\section{Overall Consideration of the Theses in Light of Seymour's Objections}

\section{A. An Unbalanced Process of Reciprocal Recognition}

The fundamental idea of multinational federalism is that majority and minority national aspirations can co-exist in the same state in conditions that are favourable to both justice and stability. By insisting on revealing identities through ongoing, reciprocal, bilateral, and multilateral discussions, Tully implies that such deliberations occur in a kind of ideal linguistic situation in which the interlocutors are required to take the others' arguments into consideration in exchanges that are both agonic and playful, and that lead to outcomes that are the point of departure for the next meeting. As Alain Noël nicely puts it, according to Tully, participants are moved principally by the strength of arguments, whereas appeals to force (the arguments of strength) are also part of the reality of multinational societies (Noël 2006, 433). The imbalance in power and in governance relations between majority and minority nations is part of the nature of multinational societies. Caught in the Wittgensteinian metaphor of language games, Tully tends to obscure the cold reality of power so that the interests of the Canadian state and its nation building in terms of unity can be compatible with taking into consideration, certainly, but also with indefinite postponement, Québec's interests in advancing its political freedom and promoting its distinct identity - interests that are curiously confined to the logic of diversity from Tully's point of view. In short, although being a great theoretical partisan of agonism, Tully is not agonic enough.

\section{B. Tully's Silence on the 1982 Imposition of a Constitutional Order on Québec}

On this issue, I have to qualify Seymour's remarks. During the Montréal conference, Tully did not completely overlook this dimension. He considered that, in so far as dissidence is always inevitable in a constitutional democracy and the Canadian framework is interpreted in the sense of the Supreme Court's decision by insisting on the four underlying principles, Québec does in fact retain complete freedom to change the rules of the game in the future, while enjoying the non-negligible benefits associated with the Charter of Rights and Freedoms. The aspect lacking in Tully's thought on this issue, in my judgment, is the absence of an attempt to reconcile these remarks during the Montréal conference with those he made in his 1995 book, Strange Multiplicity:

No constitutional amendment touching Québec's political culture was put through without the consent of the provincial government until 1982, when 
the Canadian Charter of Rights and Freedoms was enacted with the express dissent of the Québec Assembly. The amendment transferred considerable jurisdiction over property and civil rights from the provinces to the federal courts, whereas this jurisdiction was guaranteed to the provinces by the 1867 constitution, and in the case of Québec, by the Québec Act of 1774 [...] The objections the Québec government raised in the Courts, as we can now anticipate, were that the amending procedure violated the convention of consent and the amendment violated the convention of continuity, the very principles on which the federation and the consent of the Québec people to it, rests (Tully 1995, 162-163).

In his political philosophy, Tully insists strongly on the agonic freedom of individuals and peoples or, to put it differently, on their capacity to change the rules of the game. Partners have to be able to change the rules. This is part of the very nature of political freedom. Reformulating a question by Mark Wenman, we can wonder whether there should not be limits placed on this ability since partners could change the rules to such a point that the very nature of the political-constitutional game would be transformed (Wenman 2003, 177).

\section{Negotiations on Secession or Constitutional Change Governed by the Two-Majority Rule: Realistic or Not?}

Given this chapter's limitations, I cannot fully discuss this issue. I would say that this idea is no less realistic than that of the Québec sovereigntists who thought, and still think, that after three centuries or more than five hundred years, depending on the perspective taken, of living with Québec and Quebecers - not to mention the fact that Québec occupies a central geographical location and has made substantial contributions to many cycles of reconfiguring identity in Canada - the Canadian government and people who endorse Canadian nation-building would enter into negotiations on secession focusing essentially on their economic and instrumental interests, and that such negotiations would occur without turbulence under the aegis of cold rationality.

\section{Tully's Contradictions: Comparing Secessions and Constitutional Reforms.}

Tully bases his thought on the idea that, in constitutional hermeneutics, each situation is different. In both 1998 and 1981-82, the Supreme Court of Canada sought to apply its understanding of the country's constitutional framework and the four underlying principles to a specific situation requiring the reconciliation of quests for diversity and the requirements of unity. In 1998, the combined interpretations of the principles of democracy and federalism resulted in the idea of two majorities, 
in Québec and in Canada, responsible for possible negotiations on secession and providing a means of getting around the excessive inflexibility of amending formulas. At the Montréal conference, Tully develops the idea that the relative importance of the four principles can vary over time, depending on the situation. He also finds this idea in the Court's decision, and he agrees with its interpretation. However, in passing, he criticizes the justices who dissented from the famous 1981 Reference re Resolution to amend the Constitution for giving great, permanent, and definitive importance to the principle of federalism (Tully 2000, 21). In the same passage, he recognizes that this principle has become less important in the Canadian system since the Canadian Charter of Rights and Freedoms came into effect. The nuances in Tully's argumentation do not seem very persuasive to me. In order to get out of Canada, a Québec majority would have to go through a complex dialogue with the Canadian majority in strict compliance with the constitutional texts and underlying principles or, in other words, under extremely difficult practical circumstances if we are to believe Tully himself. ${ }^{10}$ However, in order to substantially transform the Canadian constitutional framework, it was possible in 1982 for the Canadian majority to do so without Québec's consent. This is in line with the interpretation that Tully offers of Canadian constitutional democracy on the basis of the 1998 decision and the theory of the flexibility and equally primordial nature of the underlying principles. I remain quite perplexed by this reading.

\section{E. The Lack of Motivation to Continue the Constitutional Conversation Over the Last Decade}

Certainly, Seymour is right to point out that there is virtually no appetite for serious discussions about important constitutional changes in political debates in Canada today. This is true of the parties and their leaders, the media and intellectual elites, and the general public and civil society. However, it is just as true to say that over the last decade Québec governments have done very little to instigate discussions in this direction. As André Burelle, an old federalist sage from Québec, says:

10 See the following passage in Tully $(1999,26)$, my translation: "For example, to obtain this international recognition, a sovereign Québec would have to engage in discussions with the eleven First Nations of Québec (which would appeal not only to Canada's constitutional duty to protect their interests but also to international law on Aboriginal peoples), with English-speaking districts that may have voted against secessions (which would campaign for partition or for the preservation of their current rights under the new constitution), with French-speaking minorities in the rest of Canada (which would demand that their rights be protected under the new Canadian constitution), with Canada concerning the new political and economic relationship and the conditions for joining NAFTA (over which Canada has a veto)." 
Québec's federalists are so afraid that Ottawa and the ROC ("Rest of Canada") will say "NO" to them that they do not dare ask the Québécois for a clear strong mandate to obtain unequivocal recognition for Québec's right to national difference and to open themselves, in compensation, to joint decision -making between sovereign partners to engage in European-style management of the interdependence of the federation's two orders of government in the face of the growing challenges of globalization (Burelle 2005, 468, my translation).

Indeed, as François Rocher has noted in trenchant research on the interpretation of Canadian federalism in Québec, the latter is not blameless in this affair. While federalism stands for a balance between autonomy and solidarity-interdependence, the first aspect has always taken precedence in Québec's historiographical tradition (Rocher 2006, 117122). This lends a degree of credibility to a point of view that is relatively widespread in English-speaking cottages in Canada today, suggesting that Québec always wants more of everything: more money, more recognition, more power, more autonomy.

\section{F. Tully's Silence on the Clarity Act}

In this chapter, my reflection has focused mainly on the diverging and contradicting interpretations that Tully has given concerning Canadian constitutional democracy and the Supreme Court's 1998 Reference re Secession of Québec, as well as on Seymour's criticism of the new understanding Tully suggested during his Montréal conference. At the beginning of the last decade, the Canadian government took the initiative to introduce legislation permitting Parliament to rule on the clear nature of a referendum question before the Québec National Assembly finished debating it, and authorizing the Canadian Parliament to assess, after a referendum, whether the majority vote obtained also meets clarity requirements. For this, the Canadian government specified that consideration had to be taken not only of the referendum results, but also of changes in Québec's situation after the referendum. It is difficult not to see this action by a key player in political-constitutional life as a unilateral move similar to those that were heavily criticized by the Supreme Court in 1998 and in Tully's interpretative work. In this context, Tully's complete silence on this legislative intervention seems surprising to say the least.

\section{G. The Practical Consequences of Tully's Procedural- Deliberative Approach}

Philosophers sometimes take themselves too seriously. Empirically, it is true that, to employ Seymour's terms, substantial internal selfdetermination has progressed very little in Québec over the last decade. 
There are many complex explanations for this, and I believe that the core reason lies in a certain fatigue in Canada and Québec's political classes after two decades during which much political debate has been devoted to the issue. ${ }^{11}$ While it is certainly important in theoretical circles, Tully's analysis has played only a very minor role in postponing effective recognition for Québec. However, it is true that things could have been different if important figures in English Canadian intellectual life, such as him, had taken a strong public stance on the Clarity Act. Incidentally Tully's colleague for two decades at McGill, Charles Taylor, published an op-ed piece in 2013 reaffirming that, with a clear question, fifty percent plus one should be enough in a future sovereignty referendum (Taylor 2013).

\section{H. Tully and the Nationalist Apology for the Canadian Constitutional Order}

On this aspect, Seymour's criticism seems exaggerated. There is no denying that the reading Tully proposes does indeed make Canada a nice but strange multiplicity, able to accommodate a wide range of belongings and to offer a framework of freedom, justice, and stability to all of its members, both individually and collectively. In the end, Tully gives arguments to imagine a Canada-Québec reconciliation that would be sufficiently generous to permit each of them to maintain both unity and identity. Tully's high praise for the Supreme Court and the considerable importance he gives it with respect to both understanding the Canadian constitutional framework and acting as a beacon for later changes in multinational societies in which there is complex or profound diversity, makes him a representative of the neo-idealist school that sees Canada as a "civilization of difference" able to exercise leadership to deepen the political education of humanity in the $21^{\text {st }}$ century. For members of this school, Canada is a "global exemplar," a "shining prototype" of the unity that must be maintained for the good of humanity. ${ }^{12}$ Over the last two decades, growing tension has often characterized the relations between Canadian nation building and Québec nation building. These relations cannot be summarized as a playful narrative jousting about recognition of identity and its indefinite postponement. Power plays have regularly interrupted and made more complex the flow of reasonable rhetoric and argumentation. In all camps, this has left traces of bitterness and resentment. I think that no one is safe from this, and attentive readers will have no trouble finding passages where such emotions emerge in my interpretations of Tully and Seymour (after all, I was a student of Tully and remain a friend

\footnotetext{
11 See, Laforest (2007, 95-97).

12 See, Millard (2008, 151-159).
} 
of both thinkers). The consistency in Tully's overall approach, both in the theoretical progression of the second and third stages, insisting on the struggles for recognition but also on citizens' freedoms and virtues in our world and in his interpretative work on the Supreme Court decision, can be found in the idea that Canadian-Québec constitutional conversations, against a backdrop of profound diversity and multiple identities overlapping one another, favour the emergence of a richer, more sophisticated form of citizenship. Gregory Millard summarizes this in a very intelligent manner:

It is enough to reiterate that integrating internal diversities within these separate forums is already a considerable challenge; debates raging around ethnocultural pluralism show this. But going further, and sustaining a richly shared institutional space across these parallel forums, with the formidable difficulties of understanding that entails, magnifies that complexity to a considerable degree. Now the greater the constitutive complexity of the polity -or, better, the deeper its diversity - the richer the demands it must place on the imaginative and empathetic horizons of citizens. And in train come greater opportunities for the realization of a maximally developmental vision of citizenship (Millard 2008, 214).

\section{Conclusion}

Beyond Canada and Québec, 2014 promised to be a dramatic year in the long quest for self-determination, either internal or external, in Scotland and Catalonia. In this context, I have considered it useful to examine in greater depth Tully and Seymour's respective views. My conclusions will be brief and preliminary.

As one of the leaders in English-speaking intellectual life and academia in Canada, Tully has kept his distance from the Canada-Québec constitutional conversation over the last decade. This is unfortunate. A partisan, like Tully, of multinational federalism and reciprocal recognition, Seymour has written at length on the many symbolic and institutional consequences that should flow, for Canada, from the veritable recognition of the existence of a Québec nation (Seymour 2001, 95-96). In so far as he is also one of the leaders of intellectual and academic life in Frenchspeaking Québec, it would have been useful if he had abandoned a certain ultra-autonomist stance and specified the meaning and consequences of membership in Canada for Québec, in particular against a background of reciprocal recognition.

Words have weight in political-philosophical debates, and they should be handled with care. Canada and its constitution are not straightjackets for Québec. Québec's political freedom has not been completely blocked by the 1982 constitutional reform. However, it seems clear to me that it 
has been substantially or seriously hindered to degrees that remain to be evaluated, against a backdrop of circumstances that could still change and about which no one can claim to have privileged foresight. The future remains open.

No matter what the depth of the state of tension or the breadth of institutional blockage in multinational societies, the first responsibility of intellectuals is to promote a culture of dialogue and recognition of the Other or Others: their identities, histories, doubts, fears, and hopes. This is based on a certain ethics of concern for, and hospitality towards, the Other, which is refractory to stances of condescension, disdain, and indifference (Gagnon 2011). When conflicts and tensions mount, this can prove very difficult. As a political virtue, courage can be demonstrated by leaders in very public actions and by anonymous citizens in a myriad of daily activities. In times of political crisis, academics and intellectuals have a clear responsibility to think and act courageously. This is a call to all of us, not only Seymour and Tully, and it is a call that is likely to challenge our colleagues in Scotland and Catalonia, as well as in Great Britain and Spain, in the near future. As I finish revising this chapter, the September 18, 2014 referendum campaign is about to start in Scotland and Catalans still do not know if they will be allowed to vote legally on the nature of their constitutional future. As a foreigner, albeit sympathetic to the cause of greater autonomy for Scotland and for Catalonia, I can claim no certainty about the pluses and minuses of the various options in Scotland. I remain convinced that the October 2012 agreement regarding the conduct of the referendum signed by the Cameron and Salmond governments was an edifying and quite remarkable achievement. ${ }^{13}$ For the future of Catalonia, and for the future of Spain, it would make great sense for Catalans to be allowed to vote in a legal manner.

13 The document can be downloaded at the following internet address: http://www. scotland.gov.uk/About/Government/concordats/Referendum-on-independence. The last paragraph of this agreement, reproduced here, should be compulsory reading for everybody in the governments of the countries where such issues emerge, including Canada and Spain: "The United Kingdom and Scottish Governments are committed, through the Memorandum of Understanding ${ }^{4}$ between them and others, to working together on matters of mutual interest and to the principles of good communication and mutual respect. The two governments have reached this agreement in that spirit. They look forward to a referendum that is legal and fair producing a decisive and respected outcome. The two governments are committed to continue to work together constructively in the light of the outcome, whatever it is, in the best interests of the people of Scotland and of the rest of the United Kingdom." 



\section{CHAPTER 10 \\ Trust and Mistrust Between Harper and Québec}

This chapter explores the complex and evolving relationship of trust and mistrust between Stephen Harper, Canada's current Prime Minister first elected in 2006 and returned to power with a majority government in 2011, and Québec. Trust and mistrust are already complex affairs for contemporary political science and federalism studies. I further complicate matters by considering, qualitatively and quantitatively, different partners in the relationship between one human being, who happens to be the most important political leader of a sophisticated federal democracy and, on the other side, a geographical entity which happens to be a distinct national society within this federation. Québec, for the purposes of this chapter, will encompass the following realities: the Province of Québec, Québec Francophones, Québec nationalism and Québec nationalists, and, finally, Québec's political leaders, which essentially refers here to Jean Charest, former Premier of Québec from 2003 to 2012. Although trust is relational, and requires levels of reciprocity, I shall look at this phenomenon mostly from Harper's perspective, exploring his political and intellectual trajectory. I do not completely ignore the other perspective, which can be glimpsed for instance by Harper's electoral fortunes in Québec in federal elections since 2004. My focus nevertheless remains on the factual, historical, and perceptual elements which, taken together, have shaped Harper's cognitive perspective of Québec, over time leading to various degrees of trust and mistrust.

The chapter will start with an exploration of these two primary concepts, trust and mistrust, in contemporary political science literature. It will then proceed to critically assess Harper's intellectual and political trajectories, concentrating on dimensions that relate to Québec, as previously and broadly characterized. This part will be further divided into three periodic sub-sections: 1986-2005, 2005-2008, and 2008-2012. In the conclusion, I wish to explore some alternatives for the future concerning the relationship between Harper and Québec.

\section{Some Reflections on Trust and its Derivatives}

Until recently, political theorists have been rather neglectful of the concept of trust, although this very idea is quite central in John Locke's liberal philosophy of sovereignty, explaining the relationship between 
the people and their elected representatives. Trust, following Locke, is always a limited affair. It can never be blind. It is revisable and consequentialist, depending on how our representatives behave when we "entrust" them with power. Before exploring in greater detail trust's cognitive dimension, I show its relevance for our topic - Harper and Québec - by quoting Ronald Watts and Wayne Norman, two Canadian academics who have respectively analyzed the role of trust in the political culture of federal regimes and its place in the context of multinational societies:

The necessary conditions for a federal solution: A first precondition is the existence of a will to federate. Federal political systems depend on consensual support and therefore are unlikely to succeed as imposed solutions. Second, since federal systems involve both self-rule and shared-rule, without some basic underlying shared values and objectives, the basis for long-run shared rule will in the end be impossible to achieve. Third, trust is necessary to make federal arrangements work. An essential condition is the development of mutual faith and trust among the different groups within a federation and an emphasis upon the spirit of mutual respect, tolerance and compromise (Watts 2010, 339).

From the point of view of the majority, the collective assent of federal partners cuts both ways: it constitutes a form of commitment and loyalty to the federal project by the national minorities and the majority alike, one that cannot be easily shirked. If minorities want assurances that the fundamental terms of partnership will not be violated without their consent, majorities will expect no less from minorities. The language of loyalty or solidarity is also likely to figure in the wording of a fair multinational constitution [...] There are tremendous benefits to trust in a federal partnership and a demonstrated commitment to anti-assimilationism is essential to secure the trust of minorities (Norman 2006, 164-165).

Watts and Norman's combined perspectives provide us with insights about the complexity of trust and mistrust in multinational regimes. François Rocher, Alexandre Pelletier, and Richard Simeon have attempted to build on these insights without neglecting the more general literature on trust in political sociology. The following remarks attempt to synthesize their main contributions. Rocher builds on the work of Russell Hardin (2006) and attempts to go beyond the confusion between trust and trustworthiness. He considers that trust is relational, whereas trustworthiness deals with the quality of the person or group to whom trust has been granted (Rocher 2012,2). Trust comes from the positive evaluation that one makes of the Other's trustworthiness. Trust, for Rocher, is the result of a calculation, of an evaluation. I believe that this is very important to keep in mind when dealing with such a Cartesian political figure as Stephen Harper. If trust is about calculating and evaluating, it is 
endowed with a major cognitive dimension. This involves a stable relationship between partners, tested by experience and basing itself on a substantial knowledge of the Other or Others. Enriched by his survey of the political sociology literature, Rocher wonders about the challenges at hand whenever scholars attempt to apply the dynamics of trust/ mistrust in multinational contexts when the insights of most of the work on trust emphasizes interpersonal dyadic relationships. In multinational contexts, social relations will involve a variety of actors including majority and minority national groups, political parties wishing to represent them, political leaders, intellectual communities, governments, and state institutions. These various entities deal not only with those of the same social "family" (i.e., parties with parties, governments with governments, and so on). They also interact with other groups or entities in a crosscutting way. Harper, for instance, as a political leader, not only deals with the Province of Québec, with the Government of Québec, with Charest as the Premier of Québec and key political interlocutor, but also, even if less systematically, with Québec nationalism and Québec's intellectual community.

Trust, however, is not exclusively a cognitive affair. It has to translate into reality in a political space, which happens to involve in multinational federations asymmetrical power relationships between majorities and minorities. Noël has written intelligently about this dimension, inviting scholars of multinational regimes, and particularly political theorists, to integrate in their reflections "the arguments of power as well as the power of arguments" (Noël 2006, 438). The existence of a power disequilibrium means that, generally, as Rocher suggests, the most important or influential group does not require the same degree of trust in its relation with minorities as the other way around. This is because its interests are more easily preserved or safeguarded. The cognitive and power dimensions of trust, as well as some others, are summarized in Table I (taken directly from Rocher 2012).

Table I: Trust-Mistrust Dynamics in a Plurinational Context Marked by the Asymmetry of Communities

\begin{tabular}{|c|c|c|c|c|}
\hline Type of Trust & $\begin{array}{c}\text { Power } \\
\text { Relation }\end{array}$ & $\begin{array}{c}\text { Institutional } \\
\text { Characteristics }\end{array}$ & $\begin{array}{c}\text { Cognitive } \\
\text { Dimension }\end{array}$ & $\begin{array}{l}\text { Normative } \\
\text { Dimension }\end{array}$ \\
\hline $\begin{array}{c}\text { Unconditional } \\
\text { Trust }\end{array}$ & Symmetrical & Double Majority & $\begin{array}{l}\text { Fusion of } \\
\text { Interests }\end{array}$ & $\begin{array}{l}\text { Trustworthiness, } \\
\text { Predictability, \& } \\
\text { General Interest }\end{array}$ \\
\hline $\begin{array}{l}\text { Moderate } \\
\text { Trust }\end{array}$ & Asymmetrical & $\begin{array}{c}\text { Conventional / } \\
\text { Constitutional } \\
\text { Veto }\end{array}$ & $\begin{array}{c}\text { Divergent } \\
\text { Interests \& } \\
\text { Common Goals }\end{array}$ & $\begin{array}{c}\text { Dialogue, } \\
\text { Compromise, \& } \\
\text { General Interest }\end{array}$ \\
\hline
\end{tabular}




\begin{tabular}{ccccc}
\hline Type of Trust & $\begin{array}{c}\text { Power } \\
\text { Relation }\end{array}$ & $\begin{array}{c}\text { Institutional } \\
\text { Characteristics }\end{array}$ & $\begin{array}{c}\text { Cognitive } \\
\text { Dimension }\end{array}$ & $\begin{array}{c}\text { Normative } \\
\text { Dimension }\end{array}$ \\
\hline $\begin{array}{c}\text { Moderate } \\
\text { Mistrust }\end{array}$ & Asymmetrical & $\begin{array}{c}\text { Political } \\
\text { Capacity to } \\
\text { Block }\end{array}$ & $\begin{array}{c}\text { Divergent } \\
\text { Interests \& } \\
\text { Disagreement } \\
\text { Concerning } \\
\text { Goals }\end{array}$ & $\begin{array}{c}\text { Pressure, } \\
\text { Compromise, \& } \\
\text { Particular } \\
\text { Interests }\end{array}$ \\
Radical & Domination & Majoritarian & Antagonical & Treason, \\
Mistrust & & Unilateralism & Interests & $\begin{array}{c}\text { Treachery, \& } \\
\text { Particular } \\
\end{array}$ \\
& & & & Interests \\
\hline
\end{tabular}

In their own work on trust relations in civil society associations in multinational contexts, Pelletier and Simeon provide a nice supplement to Rocher's typology and reflections. With regards to types of trust, they also suggest four variations:

\begin{tabular}{cc}
\hline Rocher & Pelletier and Simeon \\
\hline Unconditional Trust & Substantial Trust \\
Moderate Trust & Instrumental Trust \\
Moderate Mistrust & Cooperation Without Trust \\
Radical Mistrust & Absence of Cooperation \\
\hline
\end{tabular}

Pelletier and Simeon (2012) also insist, like Rocher, on the need, in such complex federal contexts, for an equilibrium between autonomy and interdependence. They suggest that trust always involves a combination of strategic (instrumental) and moral dimensions requiring good faith and reciprocity (Pelletier and Simeon 2012, 4). The domain of trust is always, or almost always, the realm of uncertainty. Reflecting on the two typologies of trust offered by Rocher, on the one hand, and Pelletier and Simeon, on the other hand, I wonder if it is at all theoretically or empirically possible to find such a thing as unconditional trust in a multinational context. Therefore, I prefer, prima facie, a political sociology that places substantial trust at the apex. I doubt, however, that substantial trust, in multinational contexts, can be devoid of instrumental dimensions. The logic of interest, as both Rocher and Noël insist, cannot be discarded. Therefore, I believe that Rocher's notion of moderate trust is, prima facie, more helpful than Pelletier and Simeon's category of instrumental trust. I will now consider the evolving relationships concerning trust and mistrust between Harper and Québec. 


\section{Harper and Québec}

\section{A. The Contours of Deep Mistrust, 1986-2005}

Stephen Harper is, arguably, the most important figure in Canadian politics in the new millennium. In the 2000 Canadian federal elections, the Liberal Party, led by former Prime Minister Jean Chrétien, won its third consecutive majority government. In the election's aftermath, Stockwell Day, leader of the Canadian Alliance Party, resigned. Along with the Canadian Alliance, the longstanding and other right-wing party, the Progressive Conservative Party of Canada, was easily defeated. Consider Harper's achievements since these events: in 2002, he became leader of the Canadian Alliance Party; in 2003, he was instrumental in merging the two right-wing parties and becoming leader of the new Conservative Party of Canada; in 2004, he and his party successfully reduced the Liberal Party, now led by Paul Martin, to the status of a minority government; in January 2006, Harper became Prime Minister of Canada as his party formed a minority government; and, in October 2008, Harper won a second mandate at the helm of a minority government. In May 2011, the day of his greatest triumph so far, Harper and his party won the Canadian federal election and formed their first majority government, while thoroughly demolishing two opposition parties - the Liberals led by Michael Ignatieff and the Bloc Québécois led by Gilles Duceppe. Both of these leaders were defeated in their own ridings. In the spring of 2012, the Bloc Québécois chose a new leader, Daniel Paillé, but the party was relegated to the margins of the House of Commons without official party status and the resources that go with it. The Liberals had an interim leader in Bob Rae before choosing Justin Trudeau as their new party leader in April 2013. And the New Democrats, fresh from taking most of the seats in Québec for the first time ever, chose Thomas Mulcair as leader following the death of the previous one, the much esteemed Jack Layton. Harper, in this context, reigns supreme in Canadian politics.

Born in Ontario in 1959, Harper moved to Alberta in his early twenties. He became involved in federal politics at that time, supporting Jim Hawkes, his local Conservative candidate who was elected in 1984 when Brian Mulroney became Prime Minister of Canada. He became estranged from Mulroney's government and from the Progressive Conservative Party of Canada over his disappointment with their treatment of Western Canada, their conduct of federal-provincial relations and constitutional politics during the Meech Lake saga (1987-1990), and their support of interventionist, statist economic and social policies over such matters as unemployment insurance. He sided with Preston Manning's Western populist movement, making a major speech at the founding congress of 
the Reform Party in late October 1987. Soon thereafter, he became a senior policy advisor to Manning who was selected as the Reform Party's first leader. The contours of Harper's deep mistrust and suspicion of Québec were already well established at that time. I insisted in the previous section on the fact that trust is endowed with a major cognitive dimension. This is created over time, through a multiplicity of experiences. In Harper's case, many of these experiences were shared with one major significant Other, John Weissenberger, with whom he developed a deep personal relationship in his first years in the West.

Weissenberger spent the first part of his life in Québec, as part of Montréal's Anglophone minority, during the eventful years of the October Crisis in 1970, the language laws of 1974 and 1977, and culminating with the victory of René Lévesque's sovereigntist Parti Québécois in the 1976 election. With Weissenberger, Harper came to develop a vision of Québec's language regime as curtailing freedom of expression and the primacy of individual rights. As William Johnson, Harper's biographer, argues, both developed a profoundly conservative understanding of Canada and of the world (Johnson 2005, 43). With regards to their philosophical understanding of modernity, they came to support a strongly individualistic liberal vision, considering the state as a mere instrument to support the goals and projects of individuals. Owing much to Friedrich Hayek's vision of spontaneous order, they sided with the free market and remained immensely suspicious of the state's interventions in economic and social affairs. This played a role in Harper's vision of Québec. Ever since the Quiet Revolution of the early 1960s, an upper middle-class academic and intellectual political elite used the state to serve the interests of the French-speaking majority. René Lévesque's Parti Québécois could be seen as pursuing this project. Ever since that time, Harper has sided with at least a soft libertarian approach to economic and social policies, attempting to limit the interventions of the state as much as possible (Johnson 2005, 47). Also at that time, Weissenberger and Harper were self -proclaimed conservatives in the Burkean sense, placing greater value on traditions and conventions following the British experience, emphasizing reformist gradualism and remaining deeply suspicious of radical, revolutionary change. This dimension heightened Harper's distrust of Québec. During the Quiet Revolution, statist Québec elitism had opted for radical change, and in the mid-1970s it appeared to become even more revolutionary with the Parti Québécois' sovereigntist project aimed at securing Québec's secession from Canada. On language matters, Weissenberger and Harper considered Québec profoundly disloyal.

On the one hand, according to them, Québec and Francophones from Canada benefited from Pierre Elliott Trudeau's symmetrical pan-Canadian 
language regime of official bilingualism, whereas Québec enforced within its borders a regime of official unilingualism that was detrimental to the rights of Anglophone Québecers. To make matters worse, Québec's political culture of interventionist statism was considered by them to be thoroughly entrenched in Canada, with the domination of the Liberal Party in general and Trudeau's vision in particular. Even worse, in the late 1970s, Trudeau's federal government embarked on a collision course with Alberta and other Western provinces over the control of natural resources. Along with Weissenberger, Harper was profoundly ill at ease with Québec's perceived attacks on Hayekian economic and epistemological conservatism, on Burkean's political conservatism, and on a principled conservative defence of the rule of law in the British tradition of which Canada is considered to be one of the most important heirs in the world. According to his biographer, Harper has always shown a lot of respect for Trudeau's 1982 vision of patriating the Canadian constitution, enriching it with a Charter of Rights and Freedoms and attempting to consolidate Canada as one nation. At the same time, philosophically, he was profoundly opposed to Trudeau's policies on such issues as languages and resources as well as policies that imposed Québec's culture of nationalistic statism on the whole of Canada. Trudeau and the Liberal Party, according to Harper in the mid-1980s, were obsessed with the question of Québec, neglecting the higher purposes of individual and regional justice for all Canadians.

Beyond Hayek and Burke, Weissenberger and Harper were also quite influenced in the 1980s by a book written by Peter Brimelow (1986), which looked strategically at the future of Canada in North America and in world from a rather Churchillian perspective strongly prejudiced in favour of English-speaking peoples and their contribution to the history of humanity. Brimelow offered a view of Québec's importance and role in the history of Canada. Weissenberger and Harper read the following passage about a decade after Lévesque's first victory, five years after the failed sovereignty referendum of 1980, and just as Brian Mulroney, Robert Bourassa, and other Canadian politicians were about to agree on the terms of the Meech Lake Accord, recognizing Québec as a distinct society within Canada and granting the government and the National Assembly of Québec - the State of Québec, from Harper's perspective constitutional authority to protect and promote Québec as a distinct society through legislation:

The history and politics of Québec are dominated by a single great reality: the emergence of the French-speaking nation. The process has been slow, complex and agonizing. There have been false starts, reversals and long periods of quiescence. But for over two hundred years its ultimate direction has been 
the same: towards ever greater self-expression, as the growing plant seeks the light (Brimelow 1986, 180).

From the first signing of the Meech Lake Accord in 1987, including its demise in 1990, to the Canadian and Québec referendums of 1992 over the Charlottetown Accord, Harper, alone or in solidarity with Preston Manning and the Reform Party, acted on his principled conservatism and on the cognitive and normative dimensions of his mistrust of Québec to strongly oppose the constitutional transformations that these projects offered Canada. In essence, Harper was strongly opposed to real or perceived special status for Québec, adhering to a vision of individual, provincial, and regional equality under the umbrella of Canadian rule of law. As a Westerner and as a Canadian historical conservative, he did develop an understanding of federalism that allowed for strong provinces and substantial decentralization. Meech Lake and its distinct society provisions were not only at odds with his vision of provincial equality, they also meant that the state of Québec could become even more interventionist, endowed with the constitutional authority to preserve and promote such a distinct society. Moreover, by granting Québec a veto right, Meech Lake meant that the Reform Party's cherished project of a Triple-E Senate (equal, effective, and elected) would probably never see the light of day because Québec would oppose it. Interestingly, it seems relevant while discussing trust and mistrust in multinational contexts to remark that Harper, during the Meech Lake era, thought that Québec was not asked or did not propose to grant a significant concession of its own, which could have been "surrendering a clean option to secede" (Johnson 2005, 83). Obviously, from opposite perspectives developed at the time in the Québec government or in Québec's political and intellectual circles, the Meech Lake Accord was of course interpreted in a very different light. It was linked to the radical transformation of the Canadian constitution in 1982 without the consent of Québec, and thus seen as necessary to re-establish trust in the Canadian federal project. However, my focus in this chapter insists on the significance of Harper's trajectory and of his perspective. His angle on matters of trust and mistrust remains my primary concern.

From the Charlottetown Accord to the end of the decade including the fateful months before, and after, the 1995 Québec referendum, Harper was steadfast in attempting to maintain, coldly, analytically, and precisely, the coherence of his vision of politics and of Canada. Harper had epistemological and philosophical misgivings about the conduct of statist politics in Québec. From Brimelow, he carried strong prejudices about the historical inevitability of Québec's quest for ever-greater forms of political self-expression with its strong Québec nationalism. 
Moreover, he did not like the ambiguities surrounding Québec's struggles for sovereignty and self-determination and their relationships with the rule of law in Canada and the primacy of the Canadian constitution. With Manning and the Reform Party, but also acting on his own, he sought a greater commitment to Canada as one nation on the part of Québec, and he sought greater clarity with regards to the legality of any secessionist enterprise. After the 1995 Québec Referendum, in Parliament and elsewhere, Harper initiated a variety of measures seeking greater clarity and the primacy of the rule of law. The 1998 Supreme Court of Canada Reference re Secession of Québec, and the law passed by Parliament in early 2000 under the initiative of Jean Chrétien and Stéphane Dion known as the Clarity Act, can together be regarded as offering substantial satisfaction to Harper, his actions, and his vision in the early 1990s. Taken together, the Supreme Court judgment and the Clarity Act reiterated the underlying principles of the Canadian constitution (federalism, democracy, constitutionalism and the rule of law, and respect for the rights of minorities), establishing a legal framework for the secession of a Canadian province within the categories of the constitution - following a referendum on a clear question translated into a clear answer leading to negotiations where all parties should show good faith and respect for the principles of the constitution - and specified under which conditions Parliament would consider that the question and the answer would be equally clear.

Two excerpts, quoted below, come from a motion submitted at a Reform Party Congress during the Charlottetown saga, and from an individual Member's Bill that Stephen Harper submitted to the Canadian House of Commons in 1996 in the aftermath of the second Québec referendum. These two excerpts reveal a lot about the context of the times, which was, using Rocher's typology, characterized by radical mistrust (absence of cooperation in Pelletier and Simeon 2012) of Québec nationalists and secessionists from the perspective of Harper and a broad section of Canadian opinion. Taken together, these two excerpts are, for me, the intellectual predecessors of the Canadian central government's "Plan B" in the Chrétien-Dion years and the Supreme Court's Reference re Secession of Québec and the Clarity Act itself. They contributed, possibly, to a transformation of the climate of politics in Canada in the late 1990s, from radical mistrust to moderate mistrust (Rocher) or from absence of cooperation to cooperation without trust (Pelletier and Simeon). This move from radical mistrust to moderate mistrust obviously characterizes here, if I am not mistaken, public opinion in the majority nation of a multinational federation. Beyond these excerpts, however, I believe nothing had really changed regarding Harper's deep mistrust of Québec. 
Whereas concessions made on account of this separatist threat are, for many, proving to be costly, ineffective, a source of deepening friction between Québec and the rest of Canada, and a barrier to the development of national purpose for the country as a whole [...] Be it resolved that the Reform Party state clearly its belief that Confederation should be maintained, but that it can only be maintained by a clear commitment to Canada as one nation, in which the demands and aspirations of all regions are entitled to equal status in constitutional negotiations and political debate, and in which freedom of expression is fully accepted as the basis for language policy across the country (quoted by Johnson 2005, 147).

A unilateral declaration of independence by the government of Québec or the legislature of Québec, or the refusal of either to submit to any Canadian law that applies in Québec is unlawful and of no force and effect with respect to the Constitution of Canada and the general laws of Canada and does not affect: (a) the jurisdiction of Parliament to pass laws that have effect in Québec; (b) the ability of the Government of Canada to govern Québec as a province of Canada; (c) the jurisdiction of the courts to apply the law of Canada in Québec; or (d) the continuance of Québec as a part of Canada under Canadian law (quoted by Johnson 2005, 255).

Evaluating Harper's relationship with Québec, I believe nothing of substance really changed between 1996, the year Harper submitted this Member's Bill to Parliament, and late 2004, sometime after his first federal electoral campaign as leader of the new, reunited right-wing Conservative Party of Canada. In 2004, struggling against the Liberal Party led by Paul Martin, Harper's Conservatives elected 99 members of Parliament, and reduced the Liberals to the status of a minority government. However, their performance was dismal in Québec, with less than $9 \%$ of votes and no elected representatives. From 1996 to 2004, Harper remained adamant that Québec needed no form of special status, no new substantial or symbolic recognition, and that it was legally fully integrated in Canada. In essence, the only fundamental difference between his group and their Liberal adversaries was that the Conservatives espoused a form of federalism that appeared more respectful of the powers of provinces. If nothing of substance really changed, some signs indicated that Harper could reconsider, at least in part, his own vision and approach given his understanding of Québec and of Canada. I shall consider these signs in the introduction of the next section, which deals with the period from 2005 to 2008.

\section{B. The Promises of Thin Trust, 2005-2008}

Harper's conservative vision privileges market libertarian values over the welfare state and the political culture that supports it. It promotes individual rights and family values against the hedonism and nihilism of 
much of late modernity in the West. It nurtures a politics of conflict that favours taxpayers from the private sector over welfare recipients. It harbours huge suspicions as we have seen vis-à-vis the nationalistic statism of Québec and its perceived absence of commitment vis-à-vis Canada. Lastly, it promotes an understanding of Canadian federalism that grants at least equal value to federalism and the founding of 1867 than to the refounding accomplished by Trudeau with Patriation and the Charter of Rights and Freedoms in 1982. Harper's mind fully integrates a vision of politics that sees it as primarily conflictual. In order, therefore, to secure a lasting presence for his vision with all its elements in $21^{\text {st }}$ century Canada, he believes that the Conservative Party must attempt the Herculean task of displacing the Liberal Party as the dominant party in the political system. From 1996 onwards, ever so gradually, Harper acted on the premise that in order to securely anchor his vision, to displace the Liberals, the Conservatives had to make their peace with Québec. I use the expression thin trust to characterize the shift that occurred in Harper's approach and which can be clearly seen at work in speeches he made in Québec City and Montréal in December 2005 and January 2006, respectively, in the midst of the federal electoral campaign that led to the formation of a Conservative minority government. In these speeches, and in some pronouncements thereafter, Harper coined a new doctrine called fédéralisme d'ouverture, which can be translated as open federalism or federalism of openness (Pelletier 2008; Hébert 2007). It is clear that fédéralisme d'ouverture as a form of thin trust towards Québec corresponded to what Pelletier and Simeon called instrumental trust. Once again, this is not necessarily negative or pejorative. Everybody has interests: political leaders, governments, and nations. Thin or instrumental trust represents progress from the inferior categories in our two typologies of moderate mistrust (Rocher) or cooperation without trust (Pelletier and Simeon). Over time, because trust is endowed with a cognitive dimension that integrates the meaning and consequences of experiences, thin or instrumental trust can restabilize as moderate trust. I wish to argue that however we interpret the promises of fédéralisme d'ouverture between 2005 and 2008, they failed to cement moderate trust, therefore leading to more recent relations between Harper and Québec characterized by renewed mistrust from 2008 to 2012 .

The seeds of thin or instrumental trust between Harper and Québec were already planted in 1996 when Harper established, at a philosophically conservative policy convention in Calgary, the conditions that would allow the Canadian political right to re-establish itself as a major force in order to compete with, and eventually displace, the Liberal Party as the primary party in the country. At that time, Harper believed that whenever conservative forces had coalesced to win an election, they included people 
from three groups: people from Ontario and Atlantic Canada who had traditionally supported the old Conservative Party; people from Western Canada who had historically supported various populist parties stemming from the West, which in the late 1990s was the Reform Party; and, finally, people linked with the nationalist tradition in Québec who had not completely abandoned the idea of a federal Canada as a political project (Johnson 2005, 264). In 1996, Harper had precious little to say about the ways in which such a coalition could be formed again in the future. In the ensuing years, events unfolded to create some preconditions for the realization of this project. Following Chrétien's three consecutive majority governments, the Liberal Party was becoming more and more engulfed in a fratricidal conflict involving Chrétien's supporters and those of his internal archrival, Paul Martin. The latter would ultimately prevail and replace Chrétien in the winter of 2004. In Québec, things began to change in 2003, when the Québec Liberal Party, under Jean Charest's leadership, won the April 14 election and propelled the sovereigntist Parti Québécois into opposition.

Charest and his Liberals were committed federalists and sympathetic to Canadian nationalism while remaining autonomist nationalistic Québecers. They developed a coherent approach towards Canadian federalism, wishing to improve the quality of horizontal intergovernmental relations through creating new institutions of cooperation between provinces and territories such as the Council of the Federation established in late 2003. Rapidly, Charest and Harper were successful in changing the climate of federal-provincial relations by agreeing, with other provincial leaders in the fall of 2004, to a new ten-year deal to jointly finance Canada's health system, completing this agreement with a parallel, asymmetrical accord between the central government and Québec. Paul Martin and his Liberal government were less successful in Québec with the creation of a Commission of Enquiry led by Justice John Gomery. The Commission explored the ways in which the regulations of many federal administrative departments were violated, while irregular means were employed to finance the federal Liberal Party in a vast scheme trying to reinforce a sense of Canadian allegiance in Québec in the aftermath of the 1995 referendum. The electoral fortunes of the federal Liberal Party in Québec, already weakened in 2004, would be fatally wounded because the situation was properly exploited by their adversaries. All in all, these events provided Harper with an opportunity that he began to seize during the early weeks of the federal electoral campaign in December 2005 and January 2006. This is when he expounded the major aspects of his new doctrine of fédéralisme d'ouverture, summarized here in point form: 
- beyond domineering and paternalistic federalism, show greater respect toward constitutional provincial jurisdiction and division of powers;

- foster better collaboration and coordination with provinces and circumscribe Ottawa's spending power;

- recognize the existence of a vertical fiscal imbalance between Ottawa and the provinces and show willingness to act on this problem;

- recognize the special cultural and institutional responsibilities of Québec, attributing a significant role to the government of Québec in the Canadian delegation at UNESCO;

- in Canada-Québec relations, offer a noticeable change of tone, offering hope that the federation would be modified for the better (see, Pelletier 2008; Caron and Laforest 2009).

It could be argued that Harper's surprising new flirtations with Québec was the key element that led to the Conservative victory in 2006, thus enabling him to become Prime Minister of Canada (Hébert 2007, 10). In 2006, Harper and his party made more than a modest breakthrough in Québec. They won ten seats in the province, compared to none in 2004, and garnered $24.6 \%$ of the votes, compared with $8.8 \%$ in 2004 . Between Harper and Québec, from 2005 to 2008, things were far from perfect. Harper was, and remains, far too conservative and anti-statist for Québec's left-of-center general public opinion and for its political elites. Under the circumstances, it would have been totally unreasonable to expect unconditional or substantial trust between Harper and Québec. However, for at least two years, it looked as if Harper and Québec were jointly navigating the waters of instrumental and moderate trust.

Although the Harper-led Conservative government has failed to deliver on its promise to establish a so-called Charte $d u$ fédéralisme d'ouverture, I believe there is some consensus in Québec that Harper did make significant progress on most items of this agenda between 2006 and 2008. Considering, moreover, that Harper moved through the House of Commons in late 2006 a resolution recognizing that the Québécois form a nation in a united Canada, that he generally showed great respect for the French language in his speeches, and that he has highlighted here and abroad the role of Québec in general and of Québec City in particular, in Canada's founding, it is somewhat surprising that he did not make substantial gains in Québec in the 2008 federal election. In October 2008, Harper's Conservative won the election yet again, once more forming a minority government and once more with ten seats in Québec, but with a reduced voter support of $21.7 \%$. Analyzing these matters must be done 
carefully. In truth, the engine of fédéralisme d'ouverture had been losing part of its energy since 2007 because of a variety of issues: statements about the need to circumscribe the spending power have been timid at best; moreover, some ambiguities remain concerning what Harper really meant in the nation resolution. One must add to this various Senate reform projects, coupled with the desire to establish more provincial equality in the House of Commons by giving more seats to Ontario, Alberta, and British Columbia (reform ideas met with resistance in Québec), and the idea of an Ottawa-based national securities regulator have been met with equal resistance in Québec City by sovereigntist and federalist governments. Moreover, between 2006 and 2008, Harper has shown no enthusiasm for streamlining coordination through regular and more rational conferences with provincial and territorial leaders. It is also clear that he has stayed away from the idea of re-opening the constitutional file in order to, among other matters, formally recognize Québec's national identity. Add to this the rift between Harper and Québec Premier Jean Charest dating back to the Charest's decision to reduce income taxes in the aftermath of a 2007 federal budget addressing the fiscal imbalance issue, and you get a more realistic portrait of the relationship between Harper's government and Québec. Somewhere between 2007 and 2008, the engine of thin or instrumental trust between Harper and Québec derailed. I shall explore the psychological dimensions of this reality in the next section.

\section{Renewed Mistrust, 2008-2012}

In the 2011 federal election, Harper saw his Conservative Party win comfortably, garnering 166 of 308 seats with $39.6 \%$ of the votes (see Table II ). In the days thereafter he formed his first majority cabinet. However, he did this with considerably reduced support in Québec, dropping from 10 to 5 seats and from $21.7 \%$ to $16.5 \%$ of voter support (see Table III ). During the election, seismic political changes occurred in Québec, with the New Democratic Party led by Jack Layton moving from a single seat to 58 seats, garnering $42 \%$ of voter support. Both the sovereigntist Bloc Québécois led by Gilles Duceppe and the Liberal Party led by Michael Ignatieff collapsed. In the campaign leading up to the election, it became clear that Harper and the Conservatives applied a different strategy than the one they had used in 2006 and 2008, placing much less emphasis on everything related to fédéralisme d'ouverture. Instead, the Conservative's priorities in 2011 were creating jobs, supporting families, eliminating the deficit, providing increased security to Canadians, and protecting Canada here and abroad by strengthening the Armed Forces, and investing in the development and security of the North. They had nothing particular to offer Québec voters. Clearly the richest and 
best-organized political party in Canada, the Harper-led Conservatives, attempted to secure a majority by making gains in Ontario, the Maritimes, and British Columbia, strategically selecting potential seats and cleverly segmenting the electorate. In the months following the election, the new majority government made good on its campaign promises.

Table II: Results of Canadian General Elections, 2000-2011

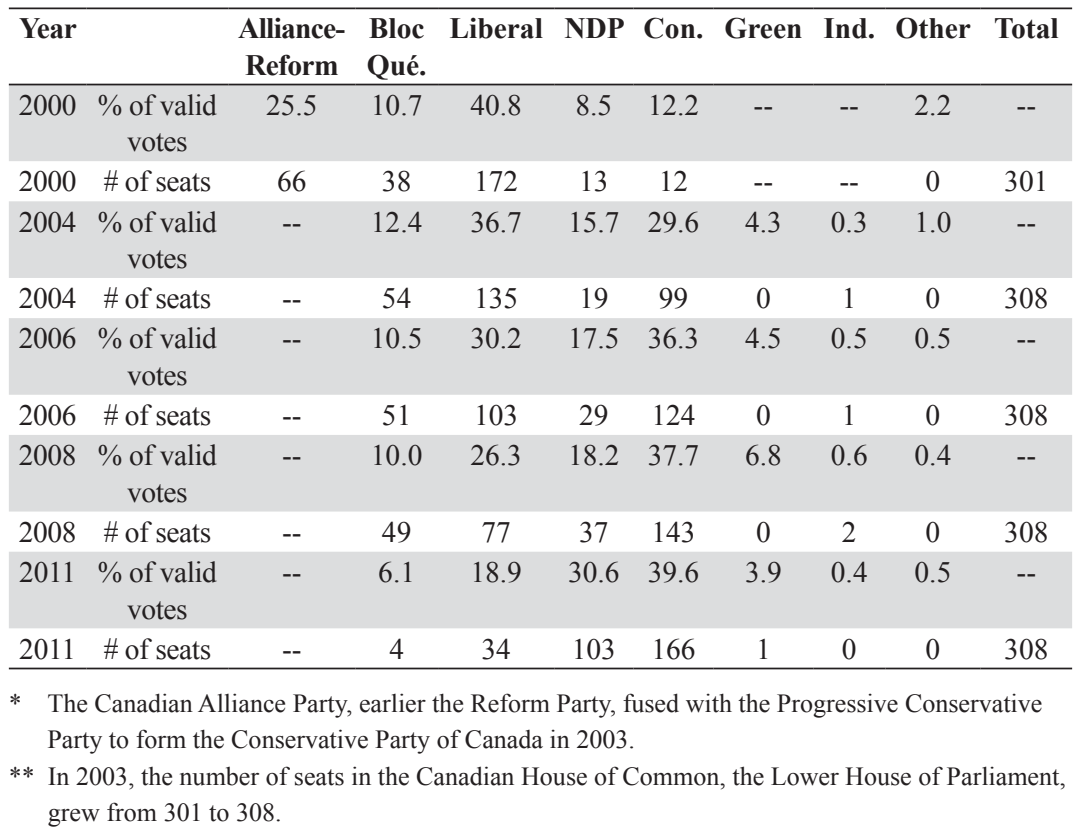

Table III: Votes Obtained by the Alliance-ReformProgressive Conservatives, and later by the Conservative Party in Québec, 2000-2011

\begin{tabular}{ccc}
\hline Election Year & \% of Votes & Number of Seats \\
\hline 2000 & 5.6 & 1 \\
2004 & 8.8 & 0 \\
2006 & 24.6 & 10 \\
2008 & 21.7 & 10 \\
2011 & 16.5 & 5 \\
\hline
\end{tabular}

The government's blueprint, as it appeared in the throne speech delivered by the Governor General on June 3, 2011, included the following 
priorities: supporting growth and employment, eliminating the deficit, supporting hard-working families, protecting Canada, helping law-abiding Canadians, helping communities and industries, and promoting integrity and responsibility. The last priority included ideas such as Senate reform, more equitable representation in the House of Commons by granting more seats to Ontario, Alberta and British Columbia, and eliminating state support for the financing of political parties. All these elements put Harper on a collision course with Charest's Liberal Government in Québec and with mainstream public opinion in the province. Cooperation did exist between Harper and Charest's governments, as was demonstrated by the agreement on sales tax harmonization devolving two billion dollars to Québec on September 30, 2011, though I would argue that this is an example of cooperation without trust. Moreover, Harper was forced after the election to reshuffle personnel in the Prime Minister's Office with the resignation of his press secretary, Dimitri Soudas, who also happened to be his top Québec advisor. He replaced him with Angelo Persichillli, a veteran of the ethnic media in Toronto who does not speak French and made disparaging comments about Québec's role in Canada in the recent past. Considering all these events, the following question needs to be asked: what really went wrong between Harper and Québec in 2007-2008 to explain this move from instrumental or thin trust to renewed mistrust?

Whenever partners in a relationship move from deep mistrust (radical mistrust, absence of cooperation, cooperation without trust, in the typologies used here) to instrumental or thin trust, the whole matter remains quite fragile. I believe that in the era of fédéralisme d'ouverture and thin trust, Harper's stance towards Québec started to change in the spring of 2007, in the context of the Québec electoral campaign that ultimately saw Charest's Liberals reduced to the status of a minority government and Mario Dumont's Action démocratique du Québec replacing the Parti Québécois as the province's Official Opposition. Prior to the election, Harper's government in Ottawa announced that it would settle the fiscal imbalance between the central government and the provinces, which had for many years been a priority for the Charest Government. As a result, Québec received over one billion dollars. Charest had always said that Québec needed this money in order to face rising costs in its two most important jurisdictions of health and education. However, at the end of a difficult first mandate, Charest chose instead to use these subsidies to offer Québec's voters substantial income tax reductions. Obviously, the Québec government is perfectly entitled to do whatever it wants, within the rule of law and within its jurisdictional ground in the federation, with its revenues. Harper, however, who had spent some political capital in the rest of Canada to recognize the legitimacy of the fiscal imbalance issue, must have been quite surprised and deeply disappointed by the 
move. Charest made matters worse, in 2007-2008, not only by disagreeing with Harper's government policy on environmental issues such as climate change, but also by vigorously expressing himself about this disagreement in a number of important international forums. Fédéralisme d'ouverture remained an important theme in the Conservative electoral platform going into the elections of October 2008, and it figured among the elements that were mentioned in the throne speech following the re-election of Harper's Conservatives with a minority government. Although the words remained there, the spirit did not. Harper's Conservatives did not lose seats in Québec in 2008, but they did not gain ground either. In terms of voter support, they suffered a marked loss, moving from $24.6 \%$ to $21.7 \%$ after a lacklustre campaign where they were cleverly attacked by the Bloc Québécois for intended federal reductions of governmental support for culture. By the end of 2008, in the weeks following Charest's third election win and second majority, with Marion Dumont and Action démocratique du Québec suffering an election disaster, and with whom Harper had established good personal relations and with whom he shared some ideological traits (e.g., suspicion vis-à-vis welfare statism and broad support for greater individual responsibility), the window of opportunity for fédéralisme d'ouverture, for instrumental or thin trust between Harper and Québec, appeared to be closing.

\section{Conclusion}

Trust and mistrust are cognitive affairs. They are experience-based, dynamic, fluid, and evolving with changing historical and political circumstances. In multinational federations, between majorities and minorities at the level of civil societies as well as between political leaders and governmental representatives, trust will always be something fragile and inherently unstable. Majorities and minorities, and their respective leaders, do not exclusively seek the same objectives. Some objectives might be commonly shared: security, social peace, economic prosperity, the crafting and preserving of a liberal polity enhancing individual rights, the normal functioning of representative and deliberative institutions of democracy, and the establishment of a pluralistic public sphere. Still, in a multinational democracy, the majority nation, as Simeon coherently showed, will put greater priority on national integration at the state-wide level, and on securing solidarity and interdependence for all individuals and groups throughout the state. On the other hand, minority nations will put greater focus on national empowerment for minorities, through increased powers, expressions of distinctiveness and asymmetry, and securing forms of symbolic and substantial recognition by the majority nation and by the state. 
In this general context, to come back to the categories explored in this chapter, unconditional trust is unimaginable. At best, majorities, minorities, and their respective leaders will reach a reasonably stabilized order hovering between what Rocher has called moderate trust and moderate mistrust, between the broader spectrum suggested by Pelletier and Simeon from cooperation without trust, to instrumental trust, to substantial trust. As suggested here, an element of instrumentality will always exists.

In order to stabilize a form of moderate trust, two lessons can be learnt from examining the relationship between Harper and Québec between 1986 and 2012. Harper's trajectory helps us understand that, when moderate or instrumental trust has been achieved, in a personal context steeped in historic mistrust and deeply-held prejudices, top elected leaders must act coherently and honour their promises. Jean Charest failed to do this in the spring of 2007 when he used the money Québec had received as a form of compensation for vertical fiscal imbalance in the federation to instead reduce provincial income taxes. Second, although they may have substantial policy differences, leaders of majorities and minorities should not act at the international level as if to widen these policy differences, without any appearance of communication on maters of mutual concern. On environmental issues, Charest showed a kind of lack of respect for Harper in a variety of international forums.

In theory at least, I believe the categories explored in this chapter can be useful to understand the relationship between leaders representing majority and minority nations in a complex federation, between their respective governments, and between the peoples and societies they represent. Unconditional trust should not be sought as it is simply beyond reach. Discussions should be frequent. Each side should understand the hierarchy of the other's objectives. Whenever possible, common speeches and deeds should be pronounced and accomplished to build up the edifice of relative trust. Promises, whenever expressed, should be kept at all costs. Finally, whenever conflicts are unavoidable, which is bound to happen considering the essence of politics in a multinational federation, channels of communication and interpersonal respect should be maintained. The rest, as ever, will be cognitive, experience-based, and revisable.

One final note is worth mentioning. All signs point to the return of deep mistrust in the relations between Harper and Québec during Pauline Marois' brief stewardship at the helm of a Parti Québécois minority government between September 2012 and April 2014. The advent of a majority Liberal and federalist government under the leadership of Philippe Couillard may change the situation. It is my belief that the analysis provided in this chapter, and its conclusions, apply to the new and evolving Harper-Couillard relationship, with the likelihood of instrumental 
flexibility on the part of Harper in the context leading up to the federal elections scheduled to be held on October 19, 2015. The examination of these matters will be one of the tasks of the Groupe de recherche sur les sociétés plurinatonales (Research Group on Plurinational Societies), of which I am a proud member, during the next few years. We will remain vigilant and readers should stay tuned. 



\section{Bibliography}

Ajzenstat, Janet. 2006. "Introduction.” In Lord Durham's Report: An abridgement of Report on the Affairs of British North America by Lord Durham, edited by Gerald M. Craig and Janet Ajzenstat. Montréal and Kingston: McGill-Queen's University Press.

Ajzenstat, Janet. 2014. Discovering Confederation: A Canadian's Story. Montréal and Kingston: McGill-Queen's University Press.

Ajzenstat, Janet, Romney, Paul, Gentles, Ian and William D. Gairdner. 1999. Canada's Founding Debates. Toronto: Stoddart.

Ajzenstat, Janet, Romney, Paul, Gentles, Ian, and William D. Gairdner. 2004. Débats sur la fondation du Canada, introduced and supplemented by Stéphane Kelly and Guy Laforest. Québec City: Presses de l'Université Laval.

Aquin, Hubert. 1977. "La fatigue culturelle du Canada français." In Blocs erratiques, edited by Hubert Aquin. Montréal: Quinze.

Aquin, Hubert. 1988. Writing Québec. Edmonton: University of Alberta Press.

Archer, Keith, Gibbins, Roger, Knopff, Rainer, and Leslie Pal. 1999. Parameters of Power: Canada's Political Institutions, $2^{\text {nd }}$ edition. Toronto: ITP Nelson.

Banting, Keith. 2006. “Open Federalism and Canada's Economic and Social Union: Back to the Future?" In Open Federalism: Interpretations, Significance, edited by Keith Banting, Roger Gibbins, Peter Leslie, Alain Noël, Richard Simeon, and Robert Young. Kingston, Ontario: Institute of Intergovernmental Relations.

Beauchemin, Jacques. 2001. "Dumont: historien de l'ambiguïté," Recherches sociographiques 42(2): 219-238.

Beauchemin, Jacques. 2002. L'histoire en trop: La mauvaise conscience des souverainistes québécois. Montréal: VLB éditeur.

Bédard, Eric. 2001. "Genèse des nations et cultures du Nouveau Monde: le magnum opus de l'historiographie moderniste," Bulletin d'histoire politique 9(2): 160-173.

Beiner, Ronald and Wayne Norman, editors. 2001. Canadian Political Philosophy. Toronto: Oxford University Press.

Bélanger, Réal, Jones, Richard and Marc Vallières. 1994. Les grands débats parlementaires 1792-1992. Québec City: Presses de l'Université Laval.

Bellavance, Marcel. 1992. Le Québec et la Confédération, un choix libre? Le clergé et la constitution de 1867. Québec City: Septentrion.

Bellavance, Marcel. 2004. Le Québec au siècle des nationalités: essai d'histoire compare. Montréal: VLB éditeur.

Bergeron, Gérard. 1977. La gouverne politique. Paris: Mouton. 
Bergeron, Gérard. 1994. Lire Etienne Parent: notre premier intellectuel (18021874). Québec City: Presses de l'Université du Québec.

Bercuson, David and Barry Cooper. 2002. Deconfederation: Canada without Québec, second edition. Toronto: Key Porter Books.

Berlin, Isaiah. 1990. The Crooked Timber of Humanity. London: Pimlico.

Bernier, Ivan. 1991. "L'impact de l'internationalisation sur le fonctionnement de l'État: le partage constitutionnel des competences." In Canadian Federalism: Meeting Global Economic Challenges?, edited by Douglas M. Brown and Murray G. Smith, 65-74. Kingston, Ontario: Institute of Intergovernmental Relations.

Bindon, Kathryn M. 1966. "Adam Thom,” Dictionary of Canadian Biography/ Dictionnaire biographique du Canada, 1881-1890, volume XI. Toronto and Québec City: University of Toronto Press and Presses de l'Université Laval.

Black, Edwin R. 1975. Divided Loyalties: Canadian Concepts of Federalism, Montréal and Kingston: McGill-Queen's University Press.

Blindenbacher, Raoul and Ronald L. Watts. 2002. "Federalism in a Changing World - A Conceptual Framework for the Conference." In Federalism in a Changing World: Learning from Each Other, edited by Raoul Blindenbacher and Arnold Koller, 7-25. Montréal and Kingston: McGill-Queen's University Press.

Blindenbacher, Raoul and Cheryl Saunders. 2005. "A Global Dialogue on Federalism: Conceptual Framework." In Constitutional Structures, Origins and Change in Federal Countries, edited by John Kincaid and Alan G. Tarr, 3-7. Montréal and Kingston: McGill-Queen's University Press.

Blouin, Jean and Gérard Bergeron. 1982. De l'autre côté de l'action. Montréal: Nouvelle optique.

Bothwell, Robert, editor. 1995. Canada and Québec: One Country Two Histories. Vancouver: University of British Columbia Press.

Bouchard, Gérard. 1999. La nation québécoise au futur et au passé. Montréal: VLB éditeur.

Bouchard, Gérard. 2000. Genèse des nations et cultures du nouveau monde: Essai d'histoire comparée. Montréal: Boréal.

Bouchard, Gérard. 2003. "Une crise de la conscience historique: Anciens et nouveaux mythes fondateurs dans l'imaginaire québécois" In Les idées mènent le Québec, edited by Stéphane Kelly, 29-52. Québec City: Presses de l'Université Laval.

Bouchard, Gérard. 2006. "Le projet de souveraineté du Québec: Sortir de l'impasse en revenant aux idées fondatrices." Le Devoir, June 17, B5.

Bouchard, Gérard. 2012. L'interculturalisme: un point de vue québécois. Montréal: Boréal.

Bouchard, Gérard and Charles Taylor. 2008. Building the Future: A Time for Reconciliation. Québec City: Bibliothèque et Archives nationales du Québec.

Bouthillette, Jean. 1972. Le Canadien Français et son double. Montréal: L'Hexagone. 
Bricker, Darrell and John Ibbitson. 2013. The Big Shift: the Seismic Change in Canadian Politics, Business and Culture, and what it Means for our Future. Toronto: Harper Collins Publishers.

Brooks, Stephen. 2009. Canadian Democracy: An Introduction, $6^{\text {th }}$ edition, Toronto: Oxford University Press.

Brouillet, Eugénie. 2005. La négation de la nation: L'identité culturelle québécoise et le fédéralisme canadien. Québec City: Septentrion.

Brun, Henri, Tremblay, Guy and Eugénie Brouillet. 2008. Droit constitutionnel, $5^{\text {th }}$ edition. Cowansville, Québec: Les Éditions Yvon Blais.

Burelle, André. 1995. Le mal canadien: essai de diagnostic et esquisse de thérapie. Montréal: Fides.

Burelle, André. 2005. Pierre Elliott Trudeau: L'intellectuel et le politique. Montréal: Fides.

Cairns, Alan. 1995. Reconfigurations: Canadian Citizenship and Constitutional Change. Montréal and Kingston: McGill-Queen's University Press.

Cairns, Alan. 2000. Citizens Plus: Aboriginal Peoples and the Canadian State. Vancouver: University of British Columbia Press.

Cairns, Alan. 2008. "Bouchard-Taylor and Nation-Building," Inroads 22 (Spring): 64-69.

Cairns, Alan. 2011. "Reflections on the Political Purposes of the Charter." In Essential Readings in Canadian Constitutional Politics, edited by Christian Leuprecht and Peter H. Russell, 370-373. Toronto: University of Toronto Press.

Caldwell, Gary. 2001. La culture publique commune: Les règles du jeu de la vie publique au Québec et les fondements de ces règles. Québec City: Éditions Nota Bene.

Cameron, David. 2002. "Canada." in Handbook of Federal Countries, 2002, edited by Ann L. Griffiths and Karl Nerenberg, 105-119. Montréal and Kingston: McGill-Queen's University Press.

Cameron, David and Richard Simeon. 2002. "Intergovernmental Relations in Canada: The Emergence of Collaborative Federalism," Publius: The Journal of Federalism 32(2): 49-72.

Caron, Jean-François and Guy Laforest. 2009. "Canada and Multinational Federalism: From the Spirit of 1982 to Stephen Harper's Open Federalism," Nationalism and Ethnic Politics 15(1): 27-55.

CBC News. 2006. "House passes motion recognizing Québécois as nation," Novermber 6, accessed September 10, 2014, http://www.cbc.ca/news/ canada/house-passes-motion-recognizing-qu $\% \mathrm{C} 3 \% \mathrm{~A} 3-\mathrm{b} \% \mathrm{C} 3 \% \mathrm{~A} 3$-cois-asnation-1.574359.

Charest, Jean. 2004. "Pour redécouvrir l'esprit federal," La Presse, November 9, A19.

Chevrier, Marc. 1996. Le fédéralisme canadien et l'autonomie du Québec: perspective historique. Québec City: Ministère des Relations internationales. 
Choudhry, Sujit. 2006. "A Canadian is....” In What is a Canadian? Forty-three Thought-Provoking Responses, edited by Irvin Studin, 117-123. Toronto: McClelland \& Stewart.

Clarkson, Stephen and Christina McCall. 1990. Trudeau and Our Times: Volume 1, The Magnificent Obsession. Toronto: McClelland \& Stewart.

Cook, Ramsay. 2005. Watching Québec: Selected Essays. Montréal and Kingston: McGill-Queen's University Press.

Craig, Gerald M. and Janet Ajzenstat. 2006. Lord Durham's Report: An Abridgement of Report on the Affiars of British North America by Lord Durham. Montréal and Kingston: McGill-Queen's University Press.

Crowley, Brian Lee. 2009. Fearful Symmetry: The Fall and Rise of Canada's Founding Values. Toronto: Key Porter.

D’Allemagne, André. 2000. Le colonialisme au Québec. Montréal: Agone.

De Rougemont, Denis. 1976. Lettre ouverte aux Européens, translated from the French by Mary Baker, Paris: Albin Michel.

Desrosiers, Léo-Paul. 1937. L'accalmie: Lord Durham au Canada. Montréal: Le Devoir.

Dion, Léon. 1995. Le duel constitutionnel Québec-Canada. Montréal: Boréal.

Dion, Stéphane. 1990. "Durham et Tocqueville sur le colonialisme liberal," Journal of Canadian Studies/Revue d'études canadiennes 25(1): 60-77.

Dion, Stéphane. 1996. "Notre pays est en danger," La Presse, March 8, B7.

Dion, Stéphane. 1999. Straight Talk: Speeches and Writings on Canadian Unity. Montréal and Kingston: McGill-Queen's University Press.

Donohue, Laura K. and Juliette N. Kayyem. 2002. "Federalism and the battle over counterterrorist law: state sovereignty, criminal law enforcement and national security," Studies in Conflict \& Terrorism 25(2): 1-24.

Dubuc, Alain. 2008. À mes amis souverainistes. Montréal: Les Éditions Voix parallèles.

Dufour, Christian. 1990. A Canadian Challenge, Le défi québécois. Vancouver: Oolichan Books.

Dufour, Christian. 2000. Lettre aux souverainistes québécois et aux fédéralistes canadiens qui sont restés fidèles au Québec. Montréal: Stanké

Dufour, Christian. 2006. Le défi français: regards croisés sur la France et le Québec Québec: Septentrion.

Dumont, Fernand. 1993. Genèse de la société québécoise. Montréal: Boréal.

Dumont, Fernand. 1987. Le sort de la culture. Montréal: L'Hexagone.

Elbaz, Mikhaël, Fortin, Andrée and Guy Laforest, editors. 1996. Les frontières de l'identité: Modernité et postmodernisme au Québec. Québec and Paris: Presses de l'Université Laval and Éditions de l'Harmattan.

English, John. 2006. Citizen of the World: The Life of Pierre Elliott Trudeau, Volume I, 1919-1968. Toronto: Knopf Canada. 
Facal, Joseph. 2000. La mondialisation, le déficit fédératif et le cas du Québec, accessed October 11, 2013, http://www.saic.gouv.qc.ca/publications/Positions/ Partie2/JosephFacal2000-2.pdf

Facal, Joseph. 2001. Le déclin du fédéralisme canadien. Montréal: VLB.

Ferretti, Andrée and Gaston Miron, editors. 1992. Les grands textes indépendantistes: écrits, discours et manifestes québécois 1774-1992. Montréal: L'Hexagone.

Fichte, Johann Gottlieb. 1922. Addresses to the German Nation. Chicago: University of Chicago Press.

Fortin, Karine. 2002. "Plus de Québécois voteraient aujourd'hui en faveur de l'Accord de Charlottetown," Le Devoir, October 21, A4.

Fry, Earl. 2001. "Québec Confronts Globalization: A Model for the Future?," Québec Studies Journal 30(1): 57-69.

Gagnon, Alain-G. 1993. "The political uses of federalism." In Comparative federalism and federation: competing traditions and future directions, edited by Michael Burgess and Alain-G. Gagnon, 15-32. Toronto: University of Toronto Press.

Gagnon, Alain-G. 1998. Québec. Oxford: Clio Press.

Gagnon, Alain-G. 2003a. Québec: State and Society, $3^{\text {rd }}$ edition. Peterborough: Broadview Press.

Gagnon, Alain-G., editor. 2003b. Québec: État et société. Montréal: Québec Amérique.

Gagnon, Alain-G., editor. 2006. Le fédéralisme canadien contemporain: fondements, traditions, institutions. Montréal: Presses de l'Université de Montréal.

Gagnon, Alain-G. 2007. Au-delà de la nation unificatrice: plaidoyer pour le fédéralisme multinational. Barcelona and Montréal: Institut d'estudis autonomics and Boréal.

Gagnon, Alain-G., editor. 2009. Contemporary Canadian Federalism: Foundations, Traditions, Institutions. Toronto: University of Toronto Press.

Gagnon, Alain-G. 2011. L'âge des incertitudes: Essais sur le fédéralisme et la diversité nationale. Québec City: Presses de l'Université Laval.

Gagnon, Alain-G. and James Tully, editors. 2001. Multinational Democracies. Cambridge: Cambridge University Press.

Gagnon, Alain-G. and Raffaele Iacovino. 2007. Federalism, Citizenship and Québec: Debating Multinationalism. Toronto: University of Toronto Press.

Gagnon, Alain-G. and Richard Simeon. 2010. "Canada." In Diversity and Unity in Federal Countries, edited by Luis Moreno and Cesar Colino. Montréal and Kingston: McGill-Queen's University Press.

Gagnon, Alain-G., Lecours, André and Geneviève Nootens. 2011. Contemporary Majoritary Nationalism. Montréal and Kingston: McGill-Queen's University Press. 
Gagnon, Serge. 1982. Québec and its Historians: 1840 to 1920. Montréal: Harvest House.

Gagnon, Serge. 1985. Québec and its Historians: The Twentieth Century. Montréal: Harvest House.

Gaudreault-Desbiens, Jean-François, and Fabien Gélinas, editors. 2005. Le fédéralisme dans tous ses états: gouvernance, identité et méthodologie, Montréal and Bruxelles: Éditions Yvon Blais and Éditions Bruylant.

Gibbins, Roger. 2000. "Federalism in a Digital World," Canadian Journal of Political Science/Revue canadienne de science politique 33(4): 667-689.

Gibbins, Roger. 2009. “Constitutional Politics.” In Canadian Politics, $5^{\text {th }}$ edition, edited by James Bickerton and Alain-G. Gagnon, 97-114. Peterborough: Broadview Press.

Godin, Pierre. 2001. René Lévesque: l'espoir et le chagrin. Montréal: Boréal.

Godin, Pierre. 2005. René Lévesque: l’homme brisé. Montréal: Boréal.

Goodhart, David. 2006. "National Anxieties," Prospect Magazine 123: 30-35.

Government of Québec. (1956). Royal Commission of Enquiry on Constitutional Problems, four volumes, Québec: Éditeur official du Québec.

Graefe, Peter. 2009. "Renouveau d'intérêt pour l'étude du fédéralisme au Québec et chantiers à ouvrir," Recherches sociographiques 50(3): 604-613.

Grand'Maison, Jacques. 2007. Pour un nouvel humanisme. Montréal: Fides.

Greer, Allan. 1992. The Patriots and the People. Toronto: University of Toronto Press.

Griffiths, Ann and Karl Nerenberg, editors. 2002. Handbook of Federal Countries 2002 of the Forum of Federations. Montréal and Kingston: McGill-Queen's University Press.

Guibernau, Montserrat. 2007. The Identity of Nations. London: Polity Press.

Hardin, Russell. 2006. Trust. Cambridge: Polity Press.

Harvey, Louis-Georges. 2005. Le printemps de l'Amérique française: Américanité, anticolonialisme et républicanisme dans le discours politique québécois, 1805 1837. Montréal: Boréal.

Hébert, Chantal. 2007. French Kiss: Stephen Harper's Blind Date with Québec. Toronto: A. Knopf Canada.

Hodge v. The Queen (Canada). 1883. UKPC 59 (15 December). http://www. bailii.org/uk/cases/UKPC/1883/1883_59.html

Ignatieff, Michael. 2001. La révolution des droits. Montréal: Boréal.

Innerarity, Daniel. 2009. Éthique de l'hospitalité, translater by Blanca Navarro Pardinas and Luc Vigneault. Québec City: Presses de l'Université Laval.

Jackson, Robert J. and Doreen Jackson. 2001. Politics in Canada: Culture, Institutions, Behaviour and Public Policy. Toronto: Prentice-Hall.

Jacques, Daniel. 1995. "La mort annoncée d'un projet insignificant," Possibles 19(1-2):198-228. 
Jacques, Daniel. 2000. "Des 'conditions gagnantes' aux 'conditions signifiantes.'” In Penser la nation québécoise, edited by Michel Venne. Montréal: Québec Amérique.

Jacques, Daniel. 2007. "La fatigue politique du Québec français," Argument 10(1): 21-45.

Jacques, Daniel. 2008. La fatigue politique du Québec français, Montréal: Boréal. Johnson, William. 2006. Stephen Harper and the Future of Canada. Toronto: Random House.

Karmis, Dimitrios. 2003. "Pluralisme et identité(s) nationale(s) dans le Québec contemporain: clarifications conceptuelles, typologie et analyse du discours." In Québec: État et société, volume 2, edited by Alain-G. Gagnon, 85-116. Montréaél: Québec/Amérique.

Karmis, Dimitrios and Wayne Norman, editors. 2005. Theories of federalism: a reader. London: Palgrave Macmillan.

Karmis, Dimitrios and François Rocher, editors. 2012. La dynamique confiance -méfiance dans les démocraties multinationals. Québec City: Presses de l'Université Laval.

Keating, Michael. 1997. Les défis du nationalisme moderne: Québec, Catalogne, Écosse. Montréal and Brussels: Les presses de l'Université de Montréal and Les presses universitaires européennes.

Keating, Michael. 2001. Plurinational Democracy: Stateless Nations in a PostSovereignty Era. Oxford: Oxford University Press.

Kelemen, Daniel R. 2004. "Globalization, Federalism, and Regulation." In Dynamics of Regulatory Change: How Globalization Affects National Regulatory Policies, edited by David Vogel and Robert A. Kagan, 269-297. Los Angeles: University of California Press.

Kelly, James and Christopher P. Manfredi, editors. 2009. Contested Constitutionalism: Reflections on the Canadian Charter of Rights and Freedoms, Vancouver: University of British Columbia Press.

Kelly, Stéphane, editor. 2003. Les idées mènent le Québec. Québec City: Presses de l'Université Laval.

Kelly, Stéphane and Guy Laforest, Guy. 2004. "Aux sources d'une tradition politique." In Débats sur la fondation du Canada, edited by Janet Ajzenstat, Paul Romney, Ian Gentles, and William D. Gairdner, 527-546. Québec City: Presses de l'Université Laval.

Kincaid, John. 2002. "Introduction.” In Handbook of Federal Countries 2002 of the Forum of Federations, edited by Ann Griffith and Karl Nerenberg, 3-13. Montréal and Kingston: McGill-Queen's University Press.

Kolboom, Ingo. 2001. Pièces d'identité: signets d'une décennie allemande. Montréal: Presses de l'Université de Montréal.

Kymlicka, Will. 1995. Multicultural Citizenship: A Liberal Theory of Minority Rights. Oxford: Oxford University Press.

Kymlicka, Will. 1998. Finding our Way: Rethinking Ethno-Cultural Relations in Canada. Toronto: Oxford University Press. 
Kymlicka, Will. 2001. Politics in the Vernacular: Nationalism, Multiculturalism and Citizenship. Toronto: Oxford University Press.

Kymlicka, Will. 2003. "Being Canadian," Government and Opposition 38(3): 357-385.

Kymlicka Will and Jean-Pierre Raviot. 1997. "Vie commune: aspects internationaux des fédéralismes," Études Internationales 28(4): 816-821.

Laborde, Cécile. 2008. Critical Republicanism: The Hijab Controversy and Political Philosophy. Oxford: Oxford University Press.

Laforest, Guy. 1992. Trudeau et la fin d'un rêve canadien. Québec City: Septentrion.

Laforest, Guy. 1995a. Trudeau and the End of a Canadian Dream. Montréal and Kingston: McGill-Queen's University Press.

Laforest, Guy. 1995b. De l'urgence. Montréal: Boréal.

Laforest, Guy. 1998a. "Se placer dans les souliers des autres partenaires dans l'union canadienne." In Sortir de l'impasse: les voies de la réconciliation, edited by Roger Gibbins and Guy Laforest, 55-84. Montréal and Kingston: Institute for Research on Public Policy.

Laforest, Guy. 1998b. "Standing in the Shoes of Other Partners in the Canadian Union." In Beyond the Impasse: Toward Reconciliation, edited by Roger Gibbins and Guy Laforest, 51-79. Montréal and Kingston: Institute for Research on Public Policy.

Laforest, Guy. 1998c. "The Need for Dialogue and how to achieve it." In Beyond the Impasse: Toward Reconciliation, edited by Roger Gibbins and Guy Laforest, 413-427. Montréal and Kingston: Institute for Research on Public Policy.

Laforest, Guy. 2004. Pour la liberté d'une société distincte. Québec City: Presses de l'Université Laval.

Laforest, Guy. 2007. "La identidad política de Canadá y la cuestión de Québec," Política Exterior 21(120): 79-97.

Laforest, Guy and Eric Montigny. 2005. "Le fédéralisme exécutif: problèmes et actualité." In Le parlementarisme canadien, $3^{\text {rd }}$ edition, edited by Réjean Pelletier and Manon Tremblay. Québec City: Presses de l'Université Laval.

Laforest, Guy and Eric Montigny. 2009. "Le fédéralisme exécutif: problèmes et actualités." In Le parlementarisme canadien, $4^{\text {th }}$ edition, edited by Réjean Pelletier and Manon Tremblay, 129-162. Québec City: Presses de l'Université Laval.

Laforest, Guy and Alain-G. Gagnon. 2009. "Comprendre la vie politique au Canada et au Québec." In Le parlementarisme canadien, $4^{\text {th }}$ edition, edited by Réjean Pelletier and Manon Tremblay, 9-39. Québec City: Presses de l’Université Laval.

Lamonde, Yvan. 2000. Histoire sociale des idées au Québec: 1760-1896. Montréal: Fides.

Lamonde, Yvan. 2001. Trajectoires de l'histoire du Québec. Québec et Montréal: Musée de la civilisation et Éditions Fides. 
Lamonde, Yvan. 2003. Histoire sociale des idées au Québec, 1896-1929. Montréal: Fides.

Lamonde, Yvan, and Claude Larin. 1998. Louis-Joseph Papineau, un demi-siècle de combats: interventions publiques. Montréal: Fides.

Lamontagne, Maurice. 1954. Le fédéralisme canadien: évolution et problèmes, Québec City: Presses de l'Université Laval.

Langlois, Simon. 2002. "Refondation de la nation au Québec." In L'annuaire du Québec 2003: toute l'année politique, sociale, économique et culturelle, edited by Roch Côté and Michel Venne. Montréal: Fides.

Larose, Jean. 1994. La souveraineté rampante. Montréal: Boréal.

LaSelva, Samuel. 1996. The Moral Foundations of Canadian Federalism: Paradoxes, Achievements, and Tragedies of Nationhood. Montréal and Kingston: McGill-Queen's University Press.

Laurin, Nicole. 2006. "L'énigme de la sociologie québécoise." In Sociologie et société québécoise: présences de Guy Rocher, edited by Céline Saint-Pierre and Jean-Philippe Warren, 161-184. Montréal: Presses de l'Université de Montréal.

Lazar, Harvey, Telford, Hamish, and Ronald L. Watts. 2003. "Divergent Trajectories: The Impact of Global and Regional Integration on Federal Systems." In The Impact of Global and Regional Integration on Federal Systems: A Comparative Analysis, edited by Harvey Lazar, Hamish Telford, and Ronald L. Watts, 1-34. Montréal and Kingston: McGill-Queen's University Press.

Lecours, André. 2002. "When Regions Go Abroad: Globalization, Nationalism and Federalism." Paper presented at Globalization, Multi-Level Governance and Democracy: Continental, Comparative and Global Perspectives, Institute of Intergovernmental Relations, Queen's University, Kingston, May 3-4.

LeDuc, Francois. 2000. Guide de la pratique des relations internationales $d u$ Québec. Québec City: Ministère des Relations internationales.

Leeson, Howard. 2011. The Patriation Minutes. Edmonton: Centre for Constitutional Studies.

Létourneau, Jocelyn. 1998a. "Pour une révolution de la mémoire collective: Histoire et conscience historique chez les Québécois," Argument 1(1): 41-57.

Létourneau, Jocelyn. 1998b. "Impenser le pays et toujours l'aimer," Cahiers internationaux de sociologie 105: 361-381.

Létourneau, Jocelyn. 2000. Passer à l'avenir: histoire, mémoire et identité dans le Québec d'aujourd'hui. Montréal: Boréal.

Létourneau, Jocelyn. 2004a. A History for the Future: Rewriting Memory and Identity in Québec. Montréal and Kingston: McGill-Queen's University Press.

Létourneau, Jocelyn. 2004b. Le Québec, les Québécois: un parcours historique. Québec City: Musée de la civilisation et Éditions Fides.

Létourneau, Jocelyn. 2006. Que veulent vraiment les Québécois. Montréal: Boréal.

Levy, Jacob. 2007. "Federalism, liberalism and the separation of loyalties," American Political Science Review 101(3): 459-477. 
MacIvor, Heather, editor. 2006. Parameters of Power: Canada's Political Institutions, $4^{\text {th }}$ edition. Toronto: Nelson.

Maclure, Jocelyn. 2003. Québec Identity: The Challenge of Pluralism. Montréal and Kingston: McGill-Queen's University Press.

Maclure, Jocelyn and Gagnon, Alain-G. 2001. Repères en mutation: Identité et citoyenneté dans le Québec contemporain. Montréal: Québec Amérique.

Maclure, Jocelyn and Charles Taylor. 2010. Laïcité et liberté de conscience. Montréal: Boréal.

Mendelsohn, Matthew. 2003. "Listen up, Canada," The Globe and Mail, July 2, 1 and 18.

McRoberts, Kenneth. 1997. Misconceiving Canada: The Struggle for National Unity. Toronto: Oxford University Press.

McRoberts, Kenneth. 1999. Un pays à refaire. Montréal: Boréal.

Meekison, J. Peter, Hamish, Telford, and Harvey Lazar, editors. 2002. Reconsidering the Institutions of Canadian Federalism, Canada: the State of the Federation 2002. Kingston, Ontatio: Queen's University's Institute for Intergovernmental Relations.

Meisel, John, Rocher, Guy, and Arthur Silver. 1999. As I Recall / Si Je Me Souviens Bien: Historical Perspectives. Montréal: Institute for Research on Public Policy.

Millard, Gregory. 2008. Secession and Self: Québec in Canadian Thought. Montréal and Kingston: McGill-Queen's University Press.

Monière, Denis. 2001. Pour comprendre le nationalisme au Québec et ailleurs. Montréal: Presses de l'Université de Montréal.

Montpetit, Éric. 2003. "Les réseaux néocorporatistes québécois à l'épreuve du fédéralisme canadien et de l'internationalisation." In Québec: État et société, vol. 2, edited by Alain-G. Gagnon, 191-208. Montréal: Québec Amérique.

Moore, Christopher. 1997. 1867: How the Fathers Made a Deal. Toronto: McClelland \& Stewart.

Morin, Claude. 1994. Les choses comme elles étaient: Une autobiographie politique. Montréal, Boréal.

Morin, Claude. 1988. Lendemains piégés. Montréal: Boréal.

Murphy, Michael, editor. 2007. Canada: The State of the Federation 2005 Québec and Canada in the New Century. Montréal and Kingston: McGillQueen's University Press.

Nemni, Max and Monique Nemni. 2006. Young Trudeau, 1919-1944: Son of Québec, Father of Canada. Toronto: McClelland \& Stewart.

Nepveu, Pierre. 2013. "Des personnes et des principes," Le Devoir, October 4, A7.

Nivola, Pietro S. 2007. "Rediscovering federalism” Issues In Governance Studies 8:1-19.

Noël, Alain. 2007. "L'héritage de la Commission Tremblay: penser l'autonomie dans un cadre fédéral rigide," Bulletin d'histoire politique 16(1): 105-122. 
Noël, Alain. 2006. "Democratic Deliberation in a Multinational Federation," Critical Review of International Social and Political Philosophy 9(3): 419-444.

Norman, Wayne. 2006. Negotiating Nationalism: Nation-Building, Federalism and Secession in the Multinational State. Toronto: Oxford University Press.

Owram, Doug. 1997. "Narrow Circles: The Historiography of Recent Canadian Historiography," National History: A Canadian Journal of Enquiry and Opinion 1(1): 5-21.

Papillon, Martin and Richard Simeon. 2004. "The Weakest Link? First Ministers' Conferences in Canadian Intergovernmental Relations." In Canada: The State of the Federation 2002: Reconsidering the Institutions of Canadian Federalism, edited by J. Peter Meekison, Hamish Telford, and Harvey Lazar, 286-302. Montréal and Kingston: McGill-Queen's University Press.

Parekh, Bhikhu. 2000. Rethinking Multiculturalism: Cultural Diversity and Political Theory. London: Macmillan Press Ltd.

Parent, Etienne. 2000. Discours, edited by Yvan Lamonde and Claude Couture. Montréal: Presses de l'Université de Montréal.

Parent, Etienne. 1999. "Une soumission honorable." In Le rouge et le bleu: une anthologie de la pensée politique au Québec de la Conquête à la Révolution tranquille, edited by Yvan Lamonde and Claude Corbo. Montréal: Presses de l'Université de Montréal.

Parti Québécois. 2005. Un projet de pays. Montréal: Parti Québécois.

Pelletier, Alexandre and Richard Simeon. 2012. "Groupes linguistiques et société civile: confiance, coopération et accommodements au sein des associations volontaires au Canada." In La dynamique confiance-méfiance dans les fédérations multinationales, edited by Dimitrios Karmis and François Rocher. Québec City: Presses de l'Université Laval.

Pelletier, Benoit. 2004. "L'état de notre fédération: la perspective du Québec." Speech delivered at a meeting of the Canada West Foundation. March 24. Accessed October 11, 2013. http://www.saic.gouv.qc.ca/centre_de_presse/ discours/2004/saic_dis20040324.htm.

Pelletier, Benoît. 2008. "Réinventer le Canada: les défis de notre pays au XXIe siècle." Speech delivered to the Canadian Club, Toronto, October 3. Accessed October 15,2013.http://www.saic.gouv.qc.ca/centre_de_presse/discours/2008/ pdf/saic_dis20081003.pdf.

Pelletier, Benoît. 2009a. "Appendix: The Future of Québec within the Canadian Federation." In Contemporary Canadian Federalism: Foundations, Traditions, Institutions, edited by Alain-G. Gagnon, 469-481. Toronto: University of Toronto Press.

Pelletier, Benoît. 2009b. "Un bilan du fédéralisme à nuancer," Recherches sociographiques 50(3): 593-599.

Pelletier, Jean-Guy. 1988. "Le crucifix à l'Assemblée nationale," Bulletin de la Bibliothèque de l'Assemblée nationale 17 (3-4): 2-11. 
Pelletier, Rejean. 2005. "Constitution et fédéralisme." In Le parlementarisme canadien, $3^{\text {rd }}$ edition, edited by Rejean Pelletier and Manon Tremblay, 37-79. Québec City: Les presses de l'Université Laval.

Pelletier, Réjean. 2008. Le Québec et le fédéralisme canadien: un regard critique. Québec City: Presses de l'Université Laval.

Pelletier, Réjean. 2009. "Constitution et fédéralisme.” In Le parlementarisme canadien, $4^{\text {th }}$ edition, edited by Réjean Pelletier and Manon Tremblay, 41-88. Québec City: Presses de l'Université Laval.

Pettigrew, Pierre. 2005. "La mise en œuvre de l'énoncé de politique internationale du Canada." Speech delivered at a meeting of the Canadian Institute of International Affairs, Ottawa, February 24.

Pratte, André. 2006. Aux pays des merveilles: essai sur les mythes politiques québécois. Montréal: VLB éditeur.

Pratte, André, editor. 2007. Reconquérir le Canada: un nouveau projet pour la nation québécoise. Montréal: Les Éditions Voix Parallèles.

Québec. Consultation Commission on Accommodation Practices Related to Cultural Differences. 2008. Building the Future. A Time for Reconciliation. Québec: Publications du Québec.

Québec. Consultation Commission on Accommodation Practices Related to Cultural Differences. 2007. Accommodation and differences, seeking common ground: Québecers speak out. Québec: Publications du Québec.

Ralston Saul, John. 1997. Reflections of A Siamese Twin: Canada at the End of the Twentieth Century. Toronto: Viking.

Rawls, John. 1993. Political Liberalism. New-York: Columbia University Press.

Rawls, John. 2001. The Law of Peoples. Boston: Harvard University Press.

Renaut, Alain. 1999. "Postérité de la querelle entre Lumières et Romantisme: le débat sur l'idée de nation." In Lumières et romantisme, edited by Alain Renaut, 365-392. Paris: Calmann-Lévy.

Requejo, Ferran. 1998. Federalisme, per à què? Barcelona: L'Hora del Present.

Requejo, Ferran. 2005a. Multinational federalism and value pluralism. London and New York: Routledge.

Requejo, Ferran. 2005b. "Federalism in Plurinational Societies: Rethinking the Ties between Catalonia, Spain, and the European Union." In Theories of Federalism: A Reader, edited by Dimitrios Karmis and Wayne Norman, 311-320. New York: Palgrave Macmillan.

Resnick, Philip. 1990. The Masks of Proteus: Canadian Reflections on the State. Montréal and Kingston: McGill-Queen's University Press.

Resnick, Philip. 2005. The European Roots of Canadian Identity. Peterborough: Broadview Press.

Ricoeur, Paul. 2000. La mémoire, l'histoire, l'oubli. Paris: Seuil.

Ricoeur, Paul. 2006. "Mémoire, histoire, oubli," Esprit 2: 20-29.

Rocher, François. 2006. "La dynamique Québec-Canada ou le refus de l'idéal fédéral." In Le fédéralisme canadien contemporain: fondements, traditions, 
institutions, edited by Alain-G. Gagnon, 93-146. Montréal: Presses de l'Université de Montréal.

Rocher, François. 2009. "The Québec-Canada Dynamic or the Negation of the Ideal of Federalism." In Contemporary Canadian Federalism: Foundations, Traditions, Institutions, edited by Alain-G. Gagnon, 81-131. Toronto: University of Toronto Press.

Rocher, François. 2012. "La construction du Canada en perspective historique: de la méfiance comme élément consubstantiel des débats constitutionnels." In La dynamique confiance-méfiance dans les fédérations multinationales, edited by Dimitrios Karmis and François Rocher, 137-164. Québec City: Presses de l'Université Laval.

Romney, Paul. 1999. Getting it Wrong: How Canadians Forgot their Past and Imperilled Confederation. Toronto: University of Toronto Press.

Roy, Gabrielle. 1984. La détresse et l'enchantement. Montréal: Boréal

Rudin, Ronald. 1997. Making History in Twentieth-Century Québec. Toronto: University of Toronto Press.

Russell, Peter. 1983. "The Political Purposes of the Canadian Charter of Rights and Freedoms," Canadian Bar Review/Revue du barreau canadien 16(1): 30-54.

Russell, Peter. 1993. Constitutional Odyssey: Can Canadians Be a Sovereign People? Toronto: University of Toronto Press.

Sancton, Andrew. 2002. "Municipalities, Cities, and Globalization: Implications for Canadian Federalism," In Canadian Federalism: Performance, Effectiveness and Legitimacy, edited by Herman Bakvis and Grace Skogstad, 261-277. Oxford: Oxford University Press.

Savoie, Donald. 1999. Governing from the Centre: The Concentration of Power in Canadian Politics. Toronto: University of Toronto Press.

Scott, F.R. 1977. Essays on the Constitution. Toronto: University of Toronto Press.

Seymour, Michel. 1999. La nation en question. Montréal: L'Hexagone.

Seymour, Michel. 2001. Le pari de la démesure: l'intransigeance canadienne face au Québec. Montréal: L'Hexagone.

Seymour, Michel. 2008. De la tolérance à la reconnaissance. Montréal: Boréal.

Seymour, Michel. 2011. "L'autodétermination interne du Québec dans la fédération canadienne." In Le fédéralisme multinational: Un modèle viable?, edited by Michel Seymour and Guy Laforest, 2-24. Bruxelles: P.I.E. Peter Lang.

Silver, Arthur. 1997. The French Canadian Idea of Confederation, 1864-1900, $2^{\text {nd }}$ edition. Toronto: University of Toronto Press.

Simard, Jean-Jacques. 1999. "Ce siècle où le Québec est venu au monde." In Québec 2000: rétrospective du XXe siècle, edited by Roch Côté, 17-78. Montréal: Fides.

Simeon, Richard. 2002. Political Science and Federalism: Seven Decades of Scholarly Engagement. Montréal and Kingston: McGill-Queen's University Press. 
Simeon, Richard. 2006. Federal-Provincial Diplomacy: the Making of Recent Policy in Canada. Toronto: University of Toronto Press.

Simeon, Richard and Ian Robinson. 2004. "The Dynamics of Canadian Federalism." In Canadian Politics, 4th edition, edited by James Bickerton and Alain-G. Gagnon, 101-126. Peterborough: Broadview Press.

Smiley, Donald. 1980. Canada in Question: Federalism in the Eighties. Toronto: McGraw-Hill-Ryerson.

Smiley, Donald. 1983. "A Dangerous Deed: The Constitution Act, 1982." In And No One Cheered: Federalism, Democracy and the Constitution Act, edited by Keith Banting and Richard Simeon, 74-95. Toronto: Metheun.

Smiley, Donald. 1987. The Federal Condition in Canada. Toronto: McGraw-Hill Ryerson.

Studin, Irvin, editor. 2006. What is a Canadian? Forty-three thought-provoking responses. Toronto: McClelland \& Stewart.

Taylor, Charles. 1991. The Malaise of Modernity. Cambridge: Harvard University Press.

Taylor, Charles. 1992a. Rapprocher les solitudes: écrits sur le fédéralisme et le nationalisme au Canada. Québec City: Presses de l'Université Laval.

Taylor, Charles. 1992b. Grandeur et misère de la modernité. Montréal: Bellarmin.

Taylor, Charles. 1996. "Les sources de l'identité modern" In Les frontières de l'identité: Modernité et postmodernisme au Québec, edited by Mikhaël Elbaz, Andrée Fortin, and Guy Laforest, 347-364. Québec City: Presses de l'Université Laval.

Taylor, Charles. 2000. "Nation culturelle, nation politique." In Penser la nation québécoise, edited by Michel Venne, 37-48. Montréal: Québec Amérique.

Taylor, Charles. 2013. "With a Clear Question, 50\% plus one is enough," The Globe and Mail, February 6, A19.

Thériault, Joseph-Yvon. 2002. Critique de l'américanité: Mémoire et démocratie au Québec. Montréal: Québec Amérique.

Tierney, Stephen. 2012. Constitutional Referendums: The Theory and Practice of Republican Deliberation. Oxford: Oxford University Press.

Tremblay, Martine. 2006. Derrière les portes closes: René Lévesque et l'exercice du pouvoir (1976-1985). Montréal, Québec Amérique.

Trudeau, Pierre Elliott. 1967. Le fédéralisme et la société canadienne-française. Montréal: Éditions HMH.

Trudeau, Pierre Elliott and Donald Johnston. 1988. Lac Meech: Trudeau parle.... Montréal: Hurtubise HMH.

Trudeau, Pierre Elliot. 1990a. "There Must be a Sense of Belonging." In Pierre Trudeau Speaks Out on Meech Lake, edited by Donald Johnston. Toronto: Stoddart Publishing Co.

Trudeau, Pierre Elliot. 1990b. "We, the People of Canada." In Pierre Trudeau Speaks Out on Meech Lake, edited by Donald Johnston. Toronto: Stoddart Publishing Co. 
Tully, James. 1993. An Approach to Political Philosophy: Locke in Contexts. Cambridge: Cambridge University Press.

Tully, James. 1995. Strange Multiplicity: Constitutionalism in an Age of Diversity. Cambridge: Cambridge University Press.

Tully, James. 1999a. Une étrange multiplicité: le constitutionnalisme à une époque de diversité. Québec: Presses de l'Université Laval.

Tully, James. 1999b. "Liberté et dévoilement dans les sociétés multinationales," Globe: Revue internationale d'études québécoises 2(2): 13-36.

Tully, James. 2000. "The Unattained yet Attainable Democracy: Canada and Québec Face the New Century." Les Grandes Conférences Desjardins, Montréal: Programme d'études sur le Québec.

Tully, James. 2001. "Introduction." In Multinational Democracies, edited by Alain-G. Gagnon and James Tully, 1-33. Cambridge: Cambridge University Press.

Tully, James. 2003. "Identity politics." In Cambridge History of TwentiethCentury Political Thought, edited by Terence Ball and Richard Bellamy, 517533. Cambridge: Cambridge University Press.

Tully, James. 2008. Public Philosophy in a New Key, two volumes. Cambridge: Cambridge University Press.

Vadeboncoeur, Pierre. 2000. L'humanité improvise. Montréal: Bellarmin.

Venne, Michel, editor. 2000. Penser la nation québécoise. Montréal: Québec Amérique.

Viau, Roger. 1962. Lord Durham. Montréal: Éditions HMH.

Vipond, Robert. 1991. Liberty and Community: Canadian Federalism and the Failure of the Constitution. Albany, New York: State University of New York Press.

Warren, Jean-Philippe. 1998. Un supplément d'âme: Les intentions primordiales de Fernand Dumont (1947-1970). Québec City: Les Presses de l'université Laval.

Watts, Ronald L. 2002. Comparaison des régimes fédéraux, $2^{\text {nd }}$ edition. Montréal and Kingston: McGill-Queen's University Press.

Watts, Ronald L. 2007. The Federal Idea and its Contemporary Relevance, Kingston: Institute of Intergovernmental Relations.

Watts, Ronald L. 2008. Comparing Federal Systems, $3^{\text {rd }}$ edition. Montréal and Kingston: McGill-Queen's University Press.

Watts, Ronald. 2010. "Comparative Reflections on Federalism and Democracy." In Federal Democracies, edited by Michael Burgess and Alain-G. Gagnon, 325-346. London: Routledge.

Webber, Jeremy. 1993. Reimagining Canada. Montréal and Kingston: McGillQueen's University Press.

Weber, Max. 1965. Essais sur la théorie de la science. Paris: Plon.

Weinstock, Daniel. 2005. "The moral psychology of federalism." In Le fédéralisme dans tous ses états: gouvernance, identité et méthodologie, edited 
by Jean-François Gaudreault-Desbiens and Fabien Gélinas, 209-226. Montréal and Bruxelles: Éditions Yvon Blais and Éditions Bruylant.

Wenman, Mark. 2003. “Agonistic Pluralism' and Three Archetypal Forms of Politics," Contemporary Political Theory 2(2): 165-186.

Woehrling, José. 2005. "La Charte canadienne des droits et libertés et ses répercussions sur la vie politique." In Le parlementarisme canadien, $3^{\text {rd }}$ edition, edited by Réjean Pelletier and Manon Tremblay, 81-118. Québec City: Presses de l'Université Laval.

Woehrling, José. 2009. "La Charte canadienne des droits et libertés et ses répercussions sur la vie politique." In Le parlementarisme canadien, $4^{\text {th }}$ edition, edited by Réjean Pelletier and Manon Tremblay, 89-128. Québec City: Presses de l'Université Laval.

Young, Brian. 1994. The Politics of Codification. The Lower Canadian Civil Code of 1866. Montréal and Kingston: McGill-Queen's University Press. 


\section{Diversitas}

The aim of this series is to study diversity by privileging an interdisciplinary approach, through political, legal, cultural and social frameworks. The proposed method of inquiry will be to appeal, at once, to the fields of political philosophy, law, political science, history and sociology. In a period characterized by the increasing diversity of contemporary societies, the authors published in this series will explore avenues for the accommodation and management of pluralism and identity. Such studies will not be limited to assessments of federal states, but will include states that are on the path to federalization as well as non-federal states. Serious efforts will be undertaken to enrich our comprehension of so-called 'nations without states', most notably Catalonia, Scotland, Flanders and Quebec. A point of emphasis will also be placed on extracting lessons from experiences with civil law relative to those cases marked by the common law tradition. Monist and competing models will be compared in order to assess the relative capacity of each model to provide responses to the question of political instability, while pursuing the quest for justice in minority societies. The series also addresses the place of cities in the management of diversity, as well as the question of migration more generally and the issue of communities characterized by overlapping and hybrid identities. A profound sensitivity to historical narratives is also expected to enrich the proposed scientific approach. Finally, the works published in this series will reveal a common aspiration to advance social and political debates without privileging any particular school of thought.

Series editor: Alain-G. Gagnon, Canada Research Chair in Quebec and Canadian Studies (CRÉQC) and Director of the Centre de recherche interdisciplinaire sur la diversité (CRIDAQ).

\section{Scientific Committee:}

Alain Dieckhoff, Institut d'Études Politiques, Paris

Hugues Dumont, Facultés Saint-Louis, Bruxelles

Avigail Eisenberg, University of Victoria, Victoria

Montserrat Guibernau, University of London, London

Will Kymlicka, Queen's University, Kingston, Canada

Guy Laforest, Université Laval, Québec 
Ramón Máiz, University of Santiago de Compostela, Santiago de Compostela

Marco Martiniello, Université de Liège, Liège

Ferran Requejo, Universidad Pompeu Fabra, Barcelona

José Maria Sauca Cano, Universidad Carlos III de Madrid, Madrid

Michel Seymour, Université de Montréal, Montréal

James Tully, University of Victoria, Victoria

Stephen Tierney, University of Edinburgh, Edinburgh

\section{Series Titles}

$\mathrm{N}^{\circ} 1$ - François Charbonneau et Martin Nadeau (dir.), L'histoire à l'épreuve de la diversité culturelle, 173 p., 2008.

No.2-Hugo Cyr, Canadian Federalism and Treaty Powers. Organic Constitutionalism at Work, 305 p., 2009.

No.3 - Ricard ZAPATA-BARRERo (ed.), Immigration and Self-government of Minority Nations, 177 p., 2009.

$\mathrm{N}^{\circ} 4$ - Ferran Requeso, Fédéralisme multinational et pluralisme de valeurs. Le cas espagnol, 199 p., 2009.

$\mathrm{N}^{\circ} 5$ - Charles GAucher et Stéphane ViBerT, Les Sourds : aux origines d'une identité plurielle, 228 p., 2010.

$\mathrm{N}^{\circ} 6$ - Christophe Parent, Le concept d'État fédéral multinational. Essai sur l'union des peuples, 495 p., 2011.

No 7 - Daniel InNerarity, The Transformation of Politics. Governing in the Age of Complex Societies, 154 p., 2010.

$\mathrm{N}^{\circ} 8$-Jacques Beauchemin (dir.), Mémoire et démocratie en occident. Concurrence des mémoires ou concurrence victimaire, 136 p., 2011.

$\mathrm{N}^{\circ} 9$-Alain-G. Gagnon et Ferran RequeJo (dir.), Nations en quête de reconnaissance. Regards croisés Québec-Catalogne, 241 p., 2011.

$\mathrm{N}^{\circ} 10$ - Michel Seymour et Guy Laforest (dir.), Le fédéralisme multinational. Un modèle viable?, 343 p., 2011.

№11 - Ramón Máız, The Inner Frontier, 223 p., 2012.

$\mathrm{N}^{\circ} 12$ - Louis-Philippe LAmpron, La hiérarchie des droits. Convictions religieuses et droits fondamentaux au Canada, 396 p., 2012.

$\mathrm{N}^{\circ} 13$ - Min Reuchamps, L'avenir du fédéralisme en Belgique et au Canada. Quand les citoyens en parlent, 264 p., 2011.

$\mathrm{N}^{\circ} 14$ - Victor Armony y Stéphanie Rousseau (eds.), Diversidad cultural, desigualdades y democratización en América Latina, 281 p., 2012. 
N 15 - Chantal Maillé, Greg M. Nielsen \& Daniel Salée (eds.), Revealing Democracy. Secularism and Religion in Liberal Democratic States, 176 p., 2013.

$\mathrm{N}^{\circ} 16$ - Eduardo J. Ruiz-VieYtez, United in Diversity? On Cultural Diversity, Democracy and Human Rights, 131 p., 2014.

$\mathrm{N}^{\circ} 17$ - Bernard Gagnon \& Jackie F. Steele (dir.), Concilier démocratie et diversité. Essais de théorie politique, 222 p., 2014.

No 18 - Alain-G. Gagnon \& José María Sauca (eds.), Negotiating Diversity. Identity, Pluralism and Democracy, 260 p., 2014.

$\mathrm{N}^{\circ} 19$ - Jorge CAGiaO y Conde \& Alfredo Gómez-Muller (dir.), Le multiculturalisme et la reconfiguration de l'unité et de la diversité dans les démocraties contemporaines, 303 p., 2014. 


\section{Peter Lang-The website}

Discover the general website of the Peter Lang publishing group: www.peterlang.com 